UNIVERSIDADE DE SÃO PAULO

ESCOLA DE ENGENHARIA DE SÃO CARLOS

\title{
MODELAGENS FÍSICA E NUMÉRICA DE SOLO COLAPSÍVEL REFORÇADO POR COLUNAS DE SOLO LATERÍTICO COMPACTADO
}

Mara Sarro Pereira 

UNIVERSIDADE DE SÃO PAULO

ESCOLA DE ENGENHARIA DE SÃO CARLOS

\title{
MODELAGENS FÍSICA E NUMÉRICA DE SOLO COLAPSÍVEL REFORÇADO POR COLUNAS DE SOLO LATERÍTICO COMPACTADO
}

\author{
Versão Corrigida \\ Original encontra-se disponível na unidade que aloja o programa \\ Mara Sarro Pereira
}

Dissertação apresentada à Escola de Engenharia de São Carlos, da Universidade de São Paulo, como requisito para obtenção do Título de Mestre em Geotecnia.

Área de Concentração: Geotecnia.

Orientadora: Prof ${ }^{\mathrm{a}}$. Dr ${ }^{\mathrm{a}}$. Cristina de Hollanda Cavalcanti Tsuha

São Carlos Julho de 2018 
AUTORIZO A REPRODUÇÃO TOTAL OU PARCIAL DESTE TRABALHO, POR QUALQUER MEIO CONVENCIONAL OU ELETRÔNICO, PARA FINS DE ESTUDO E PESQUISA, DESDE QUE CITADA A FONTE.

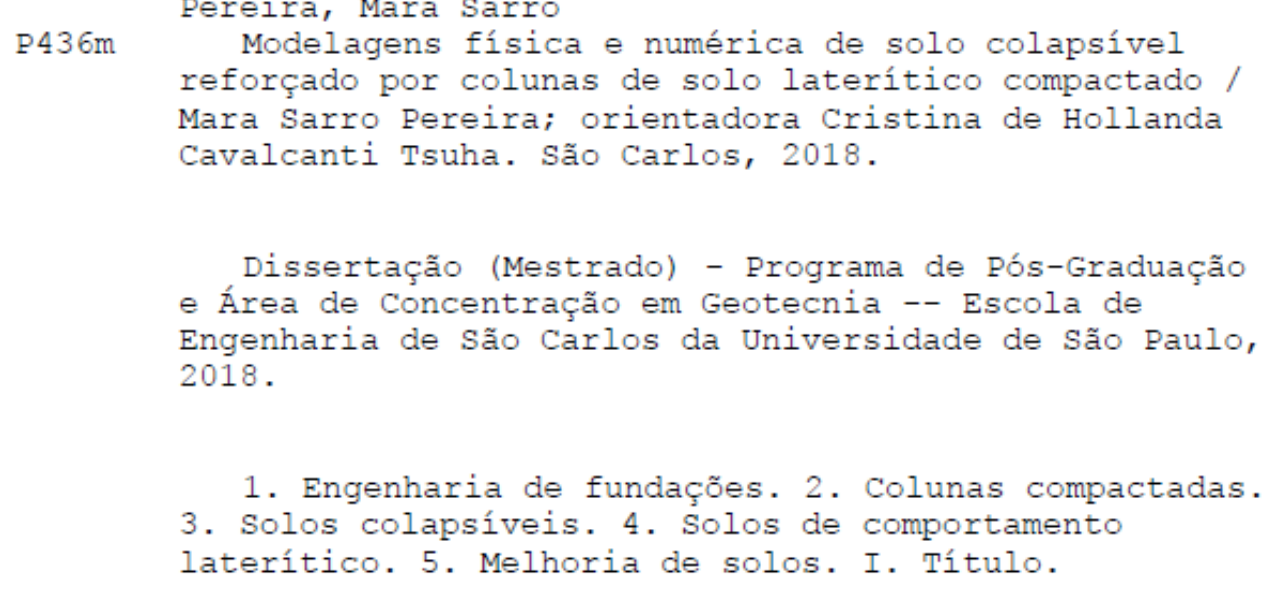




\section{FOLHA DE JULGAMENTO}

Candidata: Engenheira MARA SARRO PEREIRA.

Dilio da dissertação: "Modelogern fixica e numerica de solo colapsivel relorçado por colunas de solo latentico compactado".

Data da detesa: 05/07/2018.

Comissäo Julondora

Prof. Assaciadio Cristina de Hollanda Isuha (Orientadora)

[Escola de Encenharia de S6a Carios/EESC|

Prot, Dr. Sérgía Tibana

[Universidade stadual do Norte Fuminense_UENE]

Frot. Dr. Roger Augusto Rodrigues

[Ecola Estaduct Paudista "JGitio do Mesquita Filho"/UNESP - Bauru]
Besullado:

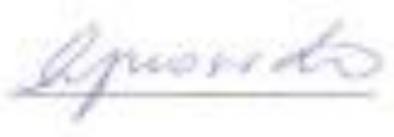

Coordenodor do Programo de Pós-Graduaçōo em Geotecria:

Prot, Dr. Edmundo Rogério Esquivel

Presidente da Comissäo de Pós-Graduaçóa:

Prot. Associado Luís Fernando Costa Alberto 



\section{Dedicatória}

Aos meus amados pais, pelo carinho e apoio incondicionais e constantes. 

Primeiramente, agradeço a Deus pelo bom desenvolvimento do projeto, por toda a força e iluminação concedidas ao longo dessa caminhada e pela saúde e bênçãos de todos os dias.

Imensamente, agradeço aos meus amados pais, José Carlos Pereira e Vera Lucia Sarro Pereira, pelo apoio incondicional, em todos os aspectos da minha vida. A meu pai, em especial, não só pelo exemplo de pessoa que venho seguindo desde sempre, mas também por todo o auxílio prestado para o desenvolvimento dessa pesquisa. Sem vocês, eu não possuiria alicerces. Não tenho nem como agradecer tudo o que vocês fizeram e fazem por mim, mas, de qualquer forma, deixo aqui expresso o meu sincero e imenso agradecimento. Por tudo.

Agradeço também à minha orientadora $\operatorname{Prof}^{\mathrm{a}}$. Dr ${ }^{\mathrm{a}}$. Cristina de H. C. Tsuha por todo o auxílio, direcionamento, suporte, orientação e preocupação prestados.

Ao professor Dr. Orencio Monje Vilar, pela honra em poder contar com todo o auxílio e direcionamento ao longo do mestrado. Pelos conhecimentos compartilhados, pelos ótimos ensinamentos (a mim felizmente proporcionados) e pela prontidão em orientar, auxiliar e guiar da melhor maneira possível.

À CAPES, pela possibilidade da concessão da bolsa de estudos e da realização da viagem à centrífuga da Universidade Estadual do Norte Fluminense (UENF) em Campos dos Goytacazes (RJ).

Aos professores doutores Sérgio Tibana, Rodrigo Martins Reis e Fernando Saboya Albuquerque, da UENF, por toda a atenção, diretrizes, acompanhamento e auxílio para a realização dos ensaios na centrífuga geotécnica.

Ao professor Dr. Daniel Dias por toda a ajuda e conhecimentos compartilhados referentes à parte de modelagem.

Aos técnicos do laboratório de mecânica dos solos, José Luís e Oscar, pela paciência e auxílio ao longo dos ensaios realizados.

Aos técnicos da centrífuga geotécnica da UENF: Eberton, Lucas, Matheus, Renato e Walber, todos fundamentais para a execução dos ensaios.

Às minhas irmãs, Mariana e Mayra, e ao meu noivo, Mayron, por todo o companheirismo e carinho de sempre.

Aos bons amigos que o mestrado felizmente me proporcionou, Bruno e Diego, por toda a caminhada e por todo o auxílio prestados durante a pesquisa. Aos amigos da equipe de 
fundações, Milena, José Antonio, Zorany, Thaise, João e Malcom pela parceria e pelos bons momentos.

A todos os professores do Departamento de Geotecnia pelos conhecimentos transmitidos ao longo da pesquisa de mestrado

Aos funcionários do Departamento de Geotecnia, Álvaro, Herivelto, Maristela e Neiva, pela prontidão em auxiliar nas questões administrativas.

A todos os amigos e colegas do Departamento de Geotecnia que fizeram do mestrado um período muito feliz. 


\section{RESUMO}

Pereira, M. S. Modelagens física e numérica de solo colapsível reforçado por colunas de solo laterítico compactado. 2018. Dissertação (Mestrado) - Escola de Engenharia de São Carlos, Universidade de São Paulo, São Carlos, 2018.

Normalmente fundações diretas não são utilizadas em solos colapsáveis devido à falta de soluções econômicas e eficientes para melhorar essa condição crítica de terreno. Quando estes solos são inundados, a água afeta sua estrutura provocando uma redução de volume, e consequentemente grandes recalques nas fundações. Por outro lado, a maioria dos solos colapsíveis em regiões tropicais está sujeita a intenso intemperismo e laterização, os quais são responsáveis por melhorar as propriedades do solo após compactação. Por esta razão, solos lateríticos colapsíveis em forma compactada são comumente usados como aterros e materiais de construção em estradas, e têm sido empregados no Brasil para possibilitar a construção de fundações diretas. A pesquisa atual foi planejada para avaliar um aprimoramento desta técnica, que seria o uso de grupos de colunas de solos lateríticos compactados, ao invés de camadas compactadas de solo muito espessas, para permitir o uso de fundações diretas. Para este estudo, ensaios edométricos simples e duplos e de modelagem física em centrífuga foram conduzidos em um solo laterítico colapsível típico do sudeste brasileiro. Complementarmente, um modelo numérico foi ajustado, usando-se os resultados dos ensaios em centrífuga, para estimar a melhoria nas propriedades do solo reforçado. Por fim, os resultados experimentais mostraram que a técnica proposta pode reduzir os recalques de colapso induzidos por umedecimento do solo, e também melhorar o comportamento carga-recalque de fundações diretas apoiadas no solo investigado.

Palavras chave: engenharia de fundações, colunas compactadas, solos colapsíveis, solos de comportamento laterítico, melhoria de solos, modelagem numérica, modelagem física, centrífuga geotécnica. 


\section{ABSTRACT}

Pereira, M. S. Physical and numerical modelling of a collapsible soil reinforced with compacted lateritic soil columns. 2018. Dissertation (Master degree) - São Carlos School of Engineering, University of São Paulo, São Carlos, 2018.

Normally, shallow foundations are not used in collapsible lateritic soils due to the lack of economic and efficient solutions to improve this critical ground condition. When these soils become wetted, the water breaks down soil arrangement and causes the soil to compress, and consequent large settlement of the foundations supported by them. In contrast, most collapsible soils in tropical regions are subject to intense weathering and laterization, which are responsible for good soil properties after compaction. For this reason, collapsible lateritic soils in compacted form are commonly used as fills and road construction materials, and have been utilised in Brazil to allow the construction of shallow foundations. The current research was designed in order to evaluate an enhancement of this technique, which is the use of groups of compacted lateritic soil columns, instead of very thick compacted soil layers, to allow the use of shallow foundations. For this study, single-point and double oedometer and physical model tests in centrifuge were conducted on a collapsible lateritic soil typical in the southeastern part of Brazil. Additionally, a numerical model was adjusted using the data from the centrifuge tests to estimate the improvement of the reinforced soil. The experimental results show that the proposed technique can reduce wetting-induced collapse settlements and also improve the loaddisplacement performance of shallow foundations in the soil investigated.

Keywords: foundation engineering, collapsible soils, lateritic soils, ground improvement, compacted columns, numerical modelling, physical modelling, geotechnical centrifuge. 
RESUMO

ABSTRACT

LISTA DE FIGURAS

1 INTRODUÇÃO

1.1 Objetivo

1.2 Organização do Trabalho

\section{REVISÃO BIBLIOGRÁFICA}

2.1 Solos de Comportamento Laterítico

2.2 Solos Não Saturados 8

2.2.1 Sucção em solos não saturados 9

$\begin{array}{ll}\text { 2.2.2 Retenção de água em um solo não saturado } & 13\end{array}$

$\begin{array}{lll}\text { 2.2.3 Resistência ao cisalhamento de solos não saturados } & 15\end{array}$

$\begin{array}{ll}\text { 2.2.4 Métodos para determinação da sucção } & 17\end{array}$

$\begin{array}{lll}2.3 & \text { Solos Colapsíveis } & 21\end{array}$

2.3.1 Ensaios Edométricos 23

2.3.2 Ensaios de Prova de Carga 27

2.3.3 Critérios de Identificação de Solos Colapsíveis. 29

$2.4 \quad$ Técnicas de Melhorias de Solos 30

2.5 Compactação do Solo 31

2.5.1 Influência do Grau de Compactação no Colapso 34

2.5.2 Compactação como Reforço de Fundações Diretas 35

2.5.3 Reforço por Colunas de Deslocamento 36

2.6 Comportamento do solo reforçado com uma malha de colunas 38

2.7 Modelagem Numérica 40

2.7.1 Método dos Elementos Finitos 41

2.7.2 Modelos Constitutivos 43

2.8 Modelagem Física 45

3 CARACTERIZAÇÃO DO SOLO ESTUDADO 50

3.1 Características Geológicas $\quad 50$

3.2 Características Geotécnicas $\quad 50$

$\begin{array}{lll}3.2 .1 & \text { Ensaios de Laboratório } & 50\end{array}$ 
4 MATERIAIS \& MÉTODOS

$\begin{array}{lll}4.1 & \text { Ensaios de Laboratório } & 58\end{array}$

$\begin{array}{lll}4.1 .1 & \text { Ensaios de Caracterização } & 58\end{array}$

\begin{tabular}{ll} 
4.1.2 & Ensaio de Compactação \\
\hline
\end{tabular}

$\begin{array}{ll}\text { 4.1.3 Ensaios Edométricos } & 59\end{array}$

$\begin{array}{lll}4.2 & \text { Modelagem Física a } 1 g & 60\end{array}$

4.3 Modelagem em Centrífuga Geotécnica 62

$\begin{array}{lll}\text { 4.3.1 Solo sem reforço } & 65\end{array}$

$\begin{array}{lll}\text { 4.3.2 } & \text { Malha de colunas com espaçamento 4.d } & 68\end{array}$

4.3.3 Malha de colunas com espaçamento 5.d 73

$\begin{array}{lll}4.4 & \text { Modelagem Numérica } & 78\end{array}$

$\begin{array}{lll}\text { 4.4.1 Modelagem de Coluna Experimental } & 79\end{array}$

4.4.2 Modelagem dos Ensaios em Centrífuga Geotécnica 83

5 ANÁLISE E RESULTADOS 86

$\begin{array}{lll}5.1 & \text { Ensaios de Laboratório } & 86\end{array}$

5.1.1 Ensaios de Caracterização 86

$\begin{array}{lll}\text { 5.1.2 } & \text { Ensaio de Compactação } & 88\end{array}$

$\begin{array}{lll}\text { 5.1.3 Ensaios Edométricos } & 89\end{array}$

$\begin{array}{lll}5.2 & \text { Modelagem Física a } 1 g & 97\end{array}$

5.3 Modelagem em Centrífuga Geotécnica 105

$\begin{array}{lll}\text { 5.3.1 Solo sem Reforço } & 106\end{array}$

$\begin{array}{ll}\text { 5.3.2 Malha de colunas com espaçamento 4.d } & 108\end{array}$

5.3.3 Malha de colunas com espaçamento 5.d 117

$\begin{array}{lll}5.4 & 120\end{array}$

$\begin{array}{lll}\text { 5.4.1 Modelagem de Coluna Experimental } & 121\end{array}$

5.4.2 Modelagem dos Ensaios em Centrífuga Geotécnica 119

6 CONCLUSÕES 132

REFERÊNCIAS BIBLIOGRÁFICAS 136

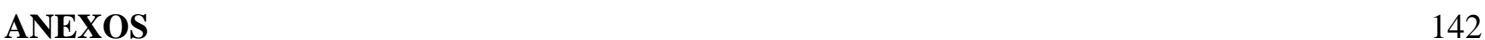




\section{LISTA DE FIGURAS}

\section{Capítulo 2}

Figura 2.1: Representação dos horizontes pedológicos de solos tropicais. Fonte: Portal de Tecnologia (2010)

Figura 2.2: Perfil de latossolo típico. Fonte: SiBCS (2006).......................................................... 5

Figura 2.3: Distribuição Geográfica dos Solos Lateríticos ao longo do Mundo. (Fonte: Santos, 2016)

Figura 2.4: Distribuição geográfica de solos de comportamento laterítico ao longo do território

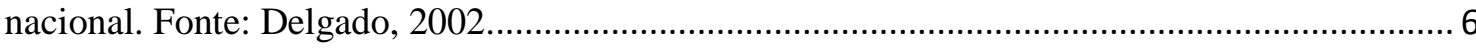

Figura 2.5: Ábaco de classificação MCT (Nogami \& Villibor, 1981)........................................... 7

Figura 2.6: Ilustração das fases de um solo não saturado (adaptado de Bueno \& Vilar, 1979).... 8 Figura 2.7: Variação da poropressão em um perfil estratigráfico. Fonte: Rodrigues, 2009........ 10 Figura 2.8: Esquema ilustrativo das sucções matricial, osmótica e total. Fonte: Rodrigues, 2009.

Figura 2.9: Esquema de ascensão de água por capilaridade (à esquerda) e diagrama de poropressões em um tubo capilar (à direita). Fonte: Rodrigues, 2009.

Figura 2.10: Curvas típicas de retenção de água para solos argilosos, arenosos e com distribuição de poros bimodal. Fonte: Rodrigues (2009).

Figura 2.11: Curvas de retenção para diferentes graus de compactação e teores de umidade.

Fonte: Pereira, 2013.

Figura 2.12: Envoltória de Resistência ao Cisalhamento para um solo não saturado. (Fredlund et al, 1978).

Figura 2.13: Esquema ilustrativo de um tensiômetro (à esquerda) e tensiômetro instalado em campo (à direita).

Figura 2.14: Esquema ilustrativo da montagem de um corpo de prova para ensaio com papel filtro.

Figura 2.15: Procedimento de montagem do corpo de prova para determinação da sucção através da técnica do papel filtro. Fonte: Pereira, 2013.

Figura 2.16: Esquema representativo de uma câmara de pressão (a) e ilustração de uma câmara de pressão com corpos de prova (b). Fonte: Pereira, 2013 
Figura 2.17: Esquema representativo de um Funil de Haines. Fonte: Pereira (2013) apud Libardi (1995).

Figura 2.18: Ilustração de danos a edificações devido ao fenômeno de recalque de colapso.

Fonte: Rodrigues \& Vilar, 2013.

Figura 2.19: Distribuição de Solos Colapsíveis ao longo do Brasil. Fonte: Rodrigues \& Vilar, 2013

Figura 2.20: Ensaio edométrico em laboratório para reprodução do efeito de colapso. Fonte:

Cintra \& Aoki, 2009.

Figura 2.21: Ensaio edométrico simples.

Figura 2.22: Ensaio edométrico duplo.

Figura 2.23: Diferença dos potenciais de colapso referentes a amostras indeformadas

comparadas às compactadas. Fonte: Ferreira \& Monteiro, 1985.

Figura 2.24: Curva carga $x$ recalque de um ensaio de prova de carga realizado com inundação durante a execução do ensaio, a um determinado nível de carregamento. Fonte: Cintra (1995).27 Figura 2.25: Carga de colapso determinada através de ensaio de prova de carga com inundação prévia do solo. Adaptado de Cintra (2004).

Figura 2.26: Curvas carga $x$ recalque de acordo com variações na sucção matricial. Fonte: Cintra (2004).

Figura 2.27: Estágios de teor de umidade segundo Hogentogler (1937).

Figura 2.28: Comparação entre a curva de resistência de um solo compactado com a curva de compactação de Proctor. Fonte: Vargas, 1977.

Figura 2.29: Curvas de potencial de colapso versus grau de compactação para as diversas umidades testadas. Adaptado de Castro et al. (2017)

Figura 2.30: Recomendação para compactação de uma camada colapsível para apoio de fundações diretas. Adaptado de Cintra \& Aoki (2009).

Figura 2.31: Compactação de Solo através de vibrador pneumático (a) e equipamento rolo pé de carneiro (b) 36

Figura 2.32: Ilustração da Técnica de melhoria de solo com coluna de deslocamento preenchida com solo através da vibrocompactação (QUINALIA, 2009).

Figura 2.33: Exemplo de malha triangular com célula unitária hexagonal................................. 39

Figura 2.34: Exemplo de malha quadrada com célula unitária quadrada.................................... 39

Figura 2.35: Exemplo de malha hexagonal com célula unitária triangular. 40 
Figura 2.36: Discretização de um meio contínuo. Adaptado de Alves (2007).

Figura 2.37: Elementos para modelagem em uma dimensão $(1 D)$. ........................................... 42

Figura 2.38: Elementos para modelagem em duas dimensões (2D). ..................................... 42

Figura 2.39: elementos para modelagem em três dimensões (3D) ............................................ 42

Figura 2.40: Princípio fundamental da modelagem em centrífuga. Fonte: Machado, 2016 ...... 46

Figura 2.41: Representação da Modelagem de modelos. Fonte: Vianna, 2005 .......................... 47

Figura 2.42: Centrífuga de Viga da Universidade Estadual do Norte Fluminense, utilizada para execução da modelagem física do presente estudo.

Figura 2.43: Centrífuga de tambor da COPPE - UFRJ em suas posições distintas (basculamento e vertical). Fonte: Machado, 2016.

\section{Capítulo 3}

Figura 3.1: Curva de retenção de água do solo pertencente ao campo experimental. Fonte:

Machado, 1998.

Figura 3.2: Ábaco de classificação MCT para amostra do campo experimental de fundações da

EESC, de acordo com Freitas (2016).

Figura 3.3: Resultados de ensaios de perfilagem SPT e CPTu realizados no campo experimental.

Fonte: Menegotto, 2004.

Figura 3.4: Resultados da variação do índice de vazios na região das colunas. Adaptado de

Freitas (2016).

Figura 3.5: Resultados da variação da massa específica seca na região das colunas. Adaptado de Freitas (2016). 54

Figura 3.6: Curvas tensão x deslocamento experimentais para as colunas de solo laterítico compactado. Adaptado de Freitas (2016).

Figura 3.7: Simplificação considerada para o cálculo do módulo de deformabilidade equivalente. Fonte: Freitas (2016)

Figura 3.8: Geometrias das colunas em modelo reduzido após escarificação. Fonte: Freitas (2016)

\section{Capítulo 4}

Figura 4.1: Locação estimada da amostragem realizada para execução dos ensaios. Fonte:

Google Maps, acesso em 03/04/2017 
Figura 4.2: Croqui esquemático, em planta, do local de amostragem (dimensões em metros). . 57 Figura 4.3: Procedimento de retirada de amostras deformadas para a realização dos ensaios.... 58 Figura 4.4: Caixa de madeirite utilizada para execução do modelo físico não centrifugado...... 61 Figura 4.5: Coluna metálica utilizada como forma para execução do furo a ser compactado com o solo laterítico. 61

Figura 4.6: Container cilíndrico utilizado para os ensaios (Centrífuga da UENF). 62

Figura 4.7: Acetato com marcações para controle do processo de compactação por volume..... 63

Figura 4.8: Elementos componentes do sistema de cravação das colunas metálicas. 63

Figura 4.9: Sistema de cravação das colunas metálicas. 64

Figura 4.10: Placa de atuação, de 20 centímetros de diâmetro, simulando o elemento de fundação direta.

Figura 4.11: Esquema ilustrativo dos ensaios a serem realizados em solo sem reforço, vista em planta (a) e em corte A-A (b), com dimensões em milímetros.

Figura 4.12: Processo de compactação do container, com controle de volume. 66

Figura 4.13: Centralização da placa de atuação com nível a laser (à esquerda) e locação da instrumentação utilizada no ensaio (à direita). 66

Figura 4.14: Imagem da câmera da centrífuga sendo preparada para início do voo. 67

Figura 4.15: Equipamento para controle e operação da centrífuga geotécnica.

Figura 4.16: Malha triangular com 7 colunas, apenas na região de projeção da placa de atuação, com espaçamento entre eixos de $4 d$. Vista em planta (a) e em corte B-B (b). Medidas em centímetros

Figura 4.17: Malha triangular com 13 colunas, tanto na região de projeção da placa de atuação quanto em seu entorno, com espaçamento entre eixos de $4 d$. Vista em planta (a) e em corte C-C (b). Medidas em milímetros. 69

Figura 4.18: Célula unitária hexagonal da malha triangular com espaçamento $4 d$. 69

Figura 4.19: Processo de cravação das colunas metálicas. Ensaio com 7 colunas (à esquerda) e com 13 colunas (à direita). .70

Figura 4.20: Colunas metálicas após término do processo de cravação. À esquerda, malha triangular com 7 colunas e, à direita, com 13.

Figura 4.21: Placa gabarito utilizada para realização dos ensaios com malha triangular de espaçamento $4 d$ e materiais utilizados para compactação das colunas de solo laterítico. 
Figura 4.22: Soquete compactador galgado para compactação das colunas por controle de volume. Ao total, foram oito camadas de $25 \mathrm{~mm}$ de altura cada (conferindo os $200 \mathrm{~mm}$ de profundidade).

Figura 4.23: Compactação das colunas sendo executada uma a uma, do centro para a periferia da malha. Detalhe para a coluna com mistura de solo + caulim. Ensaio com 7 colunas.

Figura 4.24: Processo de compactação da malha triangular com 13 colunas (imagens à esquerda e central) e container após todas as colunas terem sido compactadas (imagem à direita). .72

Figura 4.25: Malha quadrada com 4 colunas, apenas na região de projeção da placa de atuação, com espaçamento entre eixos de $5 d$. Vista em planta (a) e em corte D-D (b). Medidas em milímetros.

Figura 4.26: Ilustração da célula unitária quadrada.

Figura 4.27: Placa gabarito para a malha quadrada (à esquerda) e cravação das quatro colunas metálicas (à direita).

Figura 4.28: Colunas metálicas após término do processo de cravação.

Figura 4.29: Processo de compactação das colunas de solo laterítico para a malha quadrada com 4 colunas.

Figura 4.30: Container sem reforço preenchido até a camada número 9 (a), container sendo inundado gradativamente (b) e container após a inundação pronto para início do voo.

Figura 4.31: Ensaio com 13 estacas inundado, após realização do primeiro voo (na condição não inundada).

Figura 4.32: Geometria considerada a partir do eixo de simetria do modelo axissimétrico, com as diferentes regiões estabelecidas. Medidas em metros.

Figura 4.33: Esquema representativo do modelo axissimétrico da placa considerada

Figura 4.34: Geometria definida com os materiais e carregamento já atribuídos (à esquerda) e geração da malha de elementos finitos (à direita).

Figura 4.35: Geometria utilizada para simular o protótipo ensaiado (à esquerda) e malha de elementos finitos (à direita) em software para modelagem numérica, referente ao solo sem reforço.

Figura 4.36: Geometria referente ao protótipo (à esquerda) e malha de elementos finitos (à direita) para o solo reforçado com uma malha triangular de colunas com espaçamento $4 d$. 84 Figura 4.37: Geometria utilizada para simular o protótipo reforçado com a malha quadrada de espaçamento $5 d$ (à esquerda) e geração da malha de elementos finitos (à direita). 


\section{Capítulo 5}

Figura 5.1: Resultado da curva granulométrica obtida do ensaio de análise granulométrica conjunta.

Figura 5.2: Execução dos ensaios de limite de liquidez (à esquerda) e de plasticidade (à direita).

Figura 5.3: Gráfico de fluência obtido através do ensaio de limite de liquidez. .88

Figura 5.4: Resultados do ensaio de compactação com energia Proctor Normal realizado. 89

Figura 5.5: Imagens ilustrativas da execução do ensaio do Laboratório de Mecânica dos Solos. Corpo de prova não inundado (a); corpo de prova inundado (b) e estágio de carregamento em andamento (c). 90

Figura 5.6: Resultados do ensaio edométrico duplo realizado para um $G C=85 \%$ 91

Figura 5.7: Resultados dos ensaios edométricos simples realizados para os graus de compactação de $75 \%$ e $100 \%$.

Figura 5.8: Resultado do ensaio edométrico duplo realizado para um $G C$ de $80 \%$.

Figura 5.9: Síntese de todos os ensaios edométricos realizados para o solo estudado. 96

Figura 5.10: Compactação do solo com o soquete (a) e camada compactada no volume estipulado com escarificação da mesma para melhor entrosamento com a posterior (b).

Figura 5.11: Etapa final de compactação da caixa (a) e colocação da placa gabarito para cravação da coluna metálica (b).

Figura 5.12: Processo de cravação da coluna através da prensa (a), coluna ao final do processo de cravação (b) e furo após retirada da coluna metálica (c).

Figura 5.13: Soquete utilizado para compactação do solo no furo da coluna, galgado com 2,50 $\mathrm{cm}$ de altura para o controle de camadas.

Figura 5.14: Escarificação da caixa executada e procedimento de determinação da massa específica pela determinação do volume por submersão.

Figura 5.15: Execução do segundo modelo físico para noção da geometria da coluna compactada.

Figura 5.16: Abertura da caixa para escarificação (a), geometria das colunas de argila compactadas (b) e retirada de amostras indeformadas para obtenção dos índices físicos (c)... 101 Figura 5.17: Cilindro de Proctor modificado para compactação do solo e furo da coluna após cravação e retirada da coluna metálica. 
Figura 5.18: Coluna após término de sua compactação. À esquerda, comparação com a dimensão inicial do furo (coluna metálica) e à direita corpo de prova após abertura do cilindro.

Figura 5.19: Seção longitudinal da coluna com caulim após sua escarificação. 104

Figura 5.20: Seção transversal da coluna com caulim após sua escarificação. 104 Figura 5.21: Esquema ilustrativo do perfil longitudinal da coluna de caulim executada. Medidas em centímetros. 105

Figura 5.22: Parâmetros de compactação das colunas e do solo natural simulando as condições de campo, de acordo com a curva de Proctor obtida. 105

Figura 5.23: Superfície do container após término do ensaio não inundado do solo sem reforço.

Figura 5.24: Superfície do container após término do ensaio inundado do solo sem reforço... 107 Figura 5.25: Imagem das telas da sala de comando: câmera da centrífuga pronta para realização do ensaio (à esquerda) e programa para aquisição e gravação dos dados requeridos (deslocamento vertical e célula de carga - à direita). 107

Figura 5.26: Curvas tensão versus deslocamento obtidas para o solo sem reforço (com os valores já corrigidos para o protótipo).

Figura 5.27: Resultado da deformação sofrida pelo solo após realização do ensaio de espaçamento $4 d$ com 7 colunas.

Figura 5.28: Escarificação do container para retirada de amostras indeformadas e noção da geometria da coluna compactada com mistura de solo e caulim.

Figura 5.29: Dimensões da coluna com caulim retiradas após o término do ensaio. Medidas em centímetros

Figura 5.30: Resultado da curva tensão $x$ deslocamento obtida após realização do ensaio com 7 colunas (com os valores já corrigidos para o protótipo).

Figura 5.31: Container após a realização do ensaio de espaçamento $4 d$ com 13 colunas na condição não inundada (primeiro voo).

Figura 5.32: Container após primeiro voo, sendo inundado para segundo voo (realização do ensaio inundado).

Figura 5.33: Container após a realização do ensaio com 13 colunas na condição inundada (segundo vôo).

Figura 5.34: Coluna de solo com caulim após realização do ensaio inundado com 13 colunas. Medida em cm. 
Figura 5.35: Resultados da curva tensão $x$ deslocamento obtida após realização do ensaio de 13 colunas não inundado (primeiro voo, com ciclos de carregamento e descarregamento) e posteriormente reensaiado na condição inundada (mesmo container em um segundo voo)..... 115 Figura 5.36: Resultado da curva tensão $x$ deslocamento obtida após realização dos ensaios com 13 colunas (não inundado e inundado, com os valores já corrigidos para o protótipo) 115

Figura 5.37: Container após realização do ensaio de espaçamento $5 d$ com 4 colunas

Figura 5.38: Resultado da curva tensão $x$ deslocamento obtida com a realização do ensaio com 4 colunas de reforço (com os valores já corrigidos para o protótipo).

Figura 5.39: Compilação das curvas tensão versus deslocamento obtidas ao longo de todos os ensaios realizados em centrífuga geotécnica.

Figura 5.40: Comparação dos ensaios do solo sem reforço em centrífuga com o ensaio realizado por Freitas (2016) em prova de carga em campo.

Figura 5.41: Curva tensão $x$ deslocamento do modelo calculado na Tentativa 1 inicial.

Figura 5.42: Curva tensão $x$ deslocamento com melhor ajuste à curva experimental.

Figura 5.43: Malha deformada após o carregamento ter sido aplicado (à esquerda) e tensões efetivas obtidas após cálculo do modelo (à direita).

Figura 5.44: Tensões de cisalhamento relativas (à esquerda) e deslocamentos verticais (à direita) obtidos após cálculo do modelo.

Figura 5.45: Curva tensão $x$ deslocamento das modelagens numéricas para o solo sem reforço em comparação com a ensaiada em centrífuga geotécnica. 124

Figura 5.46: Malha deformada (à esquerda), tensões médias efetivas (ao centro) e deslocamentos verticais (à direita) para o solo sem reforço com a base compactada ao final do carregamento.

Figura 5.47: Geometria para o solo sem reforço e sem a base compactada (à esquerda), tensões médias efetivas (ao centro) e deslocamentos verticais (à direita) para o solo sem reforço sem base compactada ao final do carregamento.

Figura 5.48: Curva tensão $x$ deslocamento da modelagem numérica para o solo reforçado com uma malha de espaçamento $4 . d$ ensaiado em centrífuga geotécnica.

Figura 5.49: Malha deformada (à esquerda), tensões médias efetivas (ao centro) e deslocamentos verticais (à direita) para o solo reforçado com malha triangular de espaçamento 4.d (com base compactada) ao final do carregamento. 
Figura 5.50: Geometria e materiais considerados no modelo numérico (à esquerda); tensões médias efetivas (imagem central) e valores de deslocamentos verticais (à direita) obtidos para a malha com espaçamento $4 . d$ sem a base compactada ao final do carregamento 128 Figura 5.51: Curva tensão $x$ deslocamento da modelagem numérica para o solo reforçado com uma malha de espaçamento $5 d$ ensaiado em centrífuga geotécnica.

Figura 5.52: : Malha deformada (à esquerda), tensões médias efetivas (ao centro) e deslocamentos verticais (à direita)para o solo reforçado com malha triangular de espaçamento $5 d$ ao final do carregamento. 130

Figura 5.53: Geometria e materiais considerados no modelo numérico (à esquerda); tensões médias efetivas (imagem central) e valores de deslocamentos verticais (à direita) obtidos para a malha com espaçamento $5 d$ sem a base compactada ao final do carregamento. 


\section{LISTA DE TABELAS}

\section{Capítulo 2}

Tabela 2.1: Gravidade dos problemas ocasionados pelo efeito de colapso de acordo com o potencial de colapso proposto por Jennings e Knight (1975). Fonte: Motta, 2006.

Tabela 2.2: Gravidade dos problemas ocasionados pelo efeito de colapso de acordo com o potencial de colapso proposto por Luttenegger \& Saber (1988). Fonte: Collares, 2002. 26

Tabela 2.3: Critérios de Identificação de Colapso. Adaptado de Collares (2002) e Freitas (2016).

Tabela 2.4: Probabilidade de Colapso em função do teor de finos. (Fonte: Collares, 2002)...... 30 Tabela 2.5: Relações de escala entre protótipos e modelos. Fonte: Cintra, Levacher \& Garnier (1990).

\section{Capítulo 3}

Tabela 3.1: Determinação dos índices físicos ao longo de diferentes profundidades. 51

Tabela 3.2: Resultados dos ensaios de compactação e de caracterização. Fonte: Machado, 1998.

Tabela 3.3: Frações Granulométricas do solo. Fonte: Machado, 1998. 51

Tabela 3.4: Índices físicos obtidos pela retirada de amostras indeformadas a diversas distâncias do centro Coluna 1 (coluna de solo laterítico compactado na situação inundada). Adaptado de Freitas (2016). 54

Tabela 3.5: Valores estimados de Módulo de Deformabilidade e tensões de ruptura e admissível para as colunas e maciço natural (solo sem reforço). Fonte: Freitas (2016). 56

Tabela 3.6: Resultados obtidos da cravação estática e compactação do modelo em escala reduzida. Fonte: Freitas (2016). 56

\section{Capítulo 4}

Tabela 4.1: Quadro de ensaios realizados na modelagem física em centrífuga geotécnica. ....... 75

Tabela 4.2: Pesos específicos considerados para as diferentes regiões. 


\section{Capítulo 5}

Tabela 5.1: Síntese dos resultados dos ensaios de caracterização e compactação.

Tabela 5.2: Determinação dos índices físicos para o ensaio edométrico duplo realizado com um $G C=85 \%$ 90

Tabela 5.3: Resultado dos potenciais de colapso calculados a partir de ensaio edométrico duplo realizado com um $G C=85 \%$.

Tabela 5.4: Determinação dos Índices Físicos para os ensaios edométricos simples realizado para os graus de compactação de $75 \%$ e $100 \%$.

Tabela 5.5: Resultado dos potenciais de colapso calculados a partir dos ensaios edométricos simples realizados.

Tabela 5.6: Determinação dos índices físicos para o ensaio edométrico duplo realizado com um $G C=80 \%$ 95

Tabela 5.7: Resultado dos potenciais de colapso calculados a partir de ensaio edométrico duplo realizado com um $G C=80 \%$.

Tabela 5.8: Compilação dos resultados obtidos dos ensaios edométricos realizados. 96

Tabela 5.9: Índices físicos das amostras retiradas da coluna de solo laterítico compactado e da caixa simulando a situação de campo no modelo físico não centrifugado...... 102

Tabela 5.10: Dimensões encontradas após escarificação da coluna com caulim. 104

Tabela 5.11: Índices físicos obtidos para o ensaio do solo sem reforço na condição não inundada.

Tabela 5.12: Considerações para o processo de compactação das colunas na modelagem em centrífuga

Tabela 5.13: Resultados obtidos das amostras indeformadas retiradas do solo do container após término do ensaio com 7 colunas.

Tabela 5.14: Resultados obtidos das amostras indeformadas retiradas das colunas após término do ensaio com 7 colunas.

Tabela 5.15: Índices físicos calculados a partir de diversas amostras indeformadas retiradas das colunas após escarificação do ensaio com 13 colunas.

Tabela 5.16: Índices físicos calculados a partir de amostra indeformada retirada do container a uma profundidade de $210 \mathrm{~mm}$ após escarificação (ensaio com 13 colunas).

Tabela 5.17: Primeira estimativa de parâmetros para as diferentes regiões de solos consideradas. 
Tabela 5.18: Parâmetros com bom ajuste à curva experimental para a geometria apresentada.122 Tabela 5.19: Parâmetros arbitrados para modelagem referente ao ensaio sem reforço em centrífuga geotécnica. 124

Tabela 5.20: Parâmetros arbitrados para modelagem referente ao ensaio de espaçamento $4 d$ em centrífuga geotécnica. 126

Tabela 5.21: Parâmetros arbitrados para modelagem referente ao ensaio de espaçamento $4 d$ em centrífuga geotécnica. 129

Tabela 5.22: Síntese dos parâmetros utilizados para as modelagens numéricas realizadas. 131 
Em regiões de climas tropical e subtropical, devido aos intensos processos de intemperismo físico e químico, são muito comumente encontrados os denominados solos lateríticos ou de comportamento laterítico, caracterizados por elevadas porosidades e que exibem comportamento instável perante as variações de umidade.

Sua estabilidade estrutural é basicamente mantida pela sucção e/ou cimentação quando em condição não saturada. Contudo, quando inundado (condição na qual seu teor de umidade é aumentado tal que a sucção matricial atinja valores nunca antes presenciados), sua resistência é reduzida bruscamente e ocorre então o fenômeno de colapso, tendo por consequência recalques abruptos e pronunciados (os denominados recalques de colapso).

Por tais fenômenos estarem geralmente associados a camadas mais superficiais (ainda que espessas), torna-se corriqueira a adoção de fundações profundas que dependam de camadas mais resistentes e profundas com comportamento não colapsível, diminuindo assim os riscos quanto aos recalques pronunciados.

Outra solução amplamente difundida é a de melhoria da camada através da sua compactação. Todavia, quando os elementos de fundação estão sujeitos a carregamentos mais elevados, apresentando assim maiores dimensões, tal técnica torna-se inviável devido à necessidade de grandes volumes serem compactados para garantir a eficiência da mesma.

Sendo tais soluções mais onerosas para as obras de um modo geral, e tendo como base estudos que comprovam a redução dos efeitos de colapso devido ao processo de compactação, Freitas (2016) propôs (e avaliou in situ) uma técnica de melhoria de solos colapsíveis por meio da execução de colunas de solo laterítico compactado (colunas essas cujo próprio solo de comportamento laterítico é utilizado como material de preenchimento).

O reforço utilizando-se colunas com o próprio material colapsível compactado consiste em uma solução economicamente viável, uma vez que não serão necessários dispêndios para aquisição e transporte de um novo material (como concreto, areia, cimento, etc.) para o preenchimento das colunas, técnica que acaba por ser inclusive sustentável, tendo em vista que é evitado que o material de escavação torne-se rejeito. 
A presente pesquisa justifica-se principalmente pelo fato de não existirem estudos experimentais e numéricos que investiguem o comportamento de fundações diretas apoiadas em solos colapsíveis reforçados por grupos de colunas de solo laterítico compactado, e que também apresentem os benefícios propiciados à camada reforçada. Os resultados do presente estudo servirão como diretriz para a implantação desse tipo de reforço em obras cujos solos apresentem características semelhantes e em que seja inviável a utilização de fundações diretas.

\section{$1.1 \quad$ Objetivo}

O objetivo principal desta pesquisa reside em modelar fisicamente em centrifuga o método de reforço e melhoria de camadas de solos colapsíveis por meio de ensaios de carregamento em diferentes malhas de colunas de solo laterítico compactado. O intuito é o de estimar o comportamento de uma sapata apoiada em camada reforçada face às diferentes malhas utilizadas, e assim ser possível aperfeiçoar a técnica testada, para possibilitar a adoção de fundações diretas em solos colapsíveis sem que ocorra o efeito de colapso por inundação, e também que apresentem um melhor comportamento carga-recalque.

\subsection{Organização do Trabalho}

No Capítulo 2 do presente trabalho é apresentada uma revisão bibliográfica acerca dos assuntos envolvidos para que seja possível a compreensão da pesquisa realizada. Nesse capítulo são abordados os principais conceitos referentes aos solos de comportamento laterítico, solos não saturados e solos colapsíveis. São ainda retratadas algumas técnicas de melhorias de solos, com atenção especial à técnica de compactação e seus benefícios ao solo não saturado. Por fim, nesse capítulo, discute-se sobre modelagem física em centrífuga geotécnica, e modelagem numérica por meio do método dos elementos finitos.

O Capítulo 3 refere-se a uma caracterização do solo estudado, abordando as principais características geológicas e geotécnicas do solo estudado e utilizado nas modelagens realizadas. 
No Capítulo 4 são descritos os métodos e materiais utilizados para desenvolvimento do presente estudo. Neste capítulo são discorridos os procedimentos para realização dos ensaios de caracterização e comportamento do solo, dos ensaios em centrífuga geotécnica e também acerca das considerações e desenvolvimento da modelagem numérica.

O Capítulo 5 são apresentados os resultados e as análises obtidas durante e após a realização dos diversos ensaios e modelagens. São apresentados os resultados obtidos nos ensaios de laboratório (caracterização, compactação e edométricos), os resultados obtidos em centrífuga geotécnica e as modelagens numéricas realizadas a partir dos mesmos. Os resultados apresentados são promissores e mostram a eficiência da técnica estudada.

Por fim, no Capítulo 6, é apresentada uma conclusão acerca do estudo desenvolvido, ressaltando-se os principais aspectos e resultados, fundamentais à realização da pesquisa. É ainda brevemente comenta-se sobre possíveis trabalhos futuros que venham a complementar o estudo aqui realizado. 


\subsection{Solos de Comportamento Laterítico}

Os solos tropicais podem ser subdivididos em duas grandes classes, sendo elas a dos solos lateríticos e a dos solos saprolíticos. A primeira refere-se aos solos contidos em camadas superficiais e típicos de regiões bem drenadas com climas quentes e úmidos. Já a dos solos saprolíticos é um resultado da decomposição ou desagregação in situ da rocha matriz local, mantendo, contudo, a estrutura e características da mesma. São também designados como solos residuais jovens, em contraste com os solos superficiais lateríticos, designados como maduros.

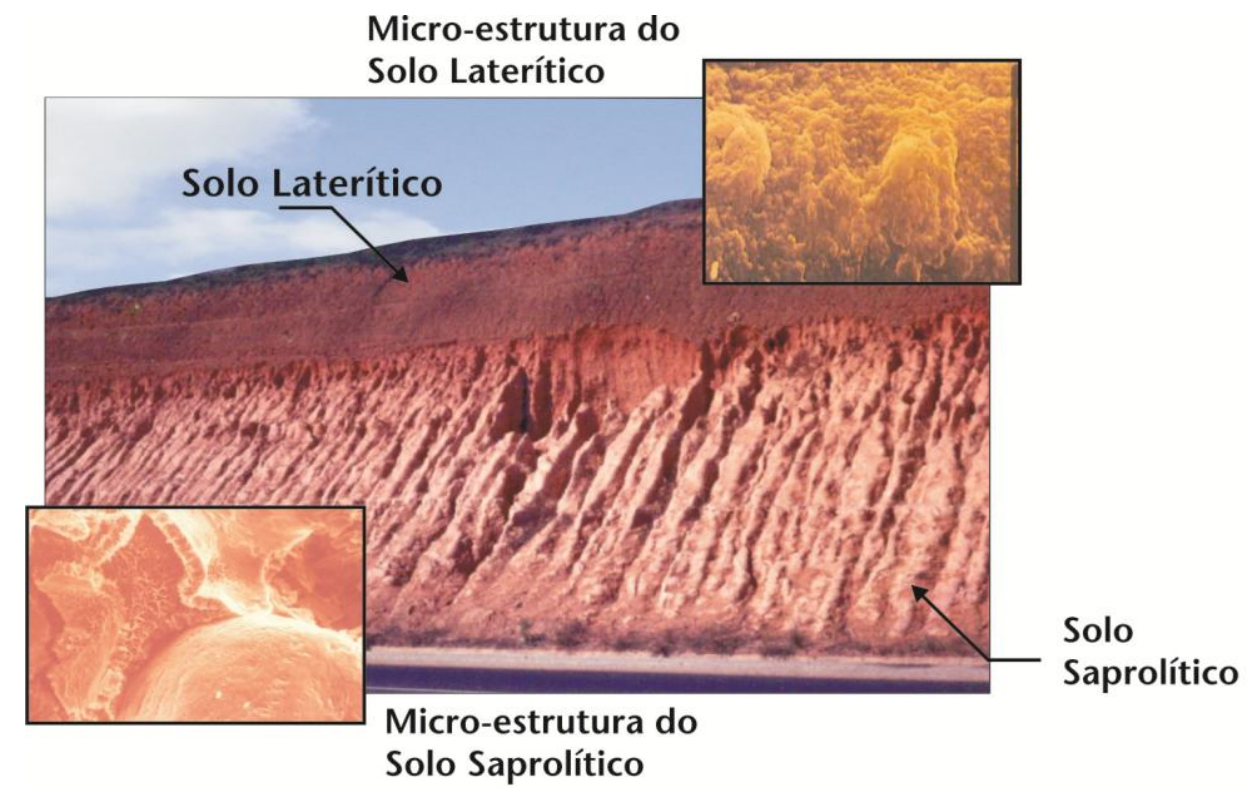

Figura 2.1: Representação dos horizontes pedológicos de solos tropicais. Fonte: Portal de Tecnologia (2010).

O Sistema Brasileiro de Classificação de Solos (SiBCS), sistema taxonômico oficial de classificação de solos no Brasil, define os latossolos como solos em avançado estágio de intemperização, muito evoluídos, resultantes de enérgicas transformações no material constitutivo. São típicos das regiões equatoriais e tropicais, ocorrendo também em zonas subtropicais e são também consideravelmente profundos (ou seja, apresentam camadas espessas). No Brasil, são encontrados em aproximadamente $32 \%$ de seu território. 


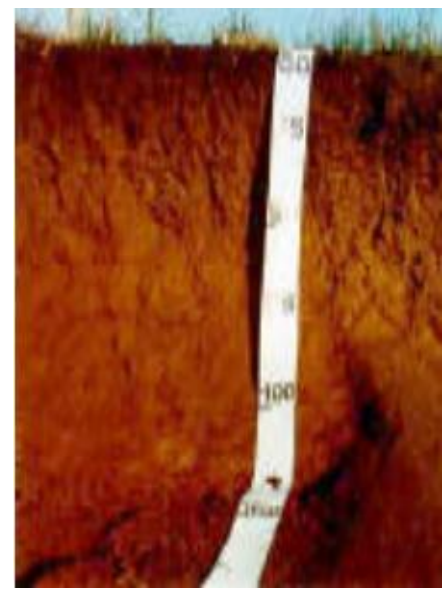

Figura 2.2: Perfil de latossolo típico. Fonte: SiBCS (2006).

De acordo com Mélo (2011), o termo "laterita" foi criado no início do século XIX por Buchanan para designação de um material ferruginoso oriundo da alteração do granito da região de Malabar, na Índia. Tal material apresentava uma propriedade particular de possibilitar seu corte em blocos quando retirado da jazida e, posteriormente, sofrer endurecimento quando exposto ao ar. Por esse motivo, tal material era comumente utilizado na construção civil como tijolo, o qual, em latim, é denominado later.

"Laterita" tem sido utilizado, principalmente no campo da geomorfologia, para designação de depósitos naturais endurecidos provenientes do intemperismo físico e químico sofrido pela rocha e pelos materiais superficiais locais. Tal intemperismo está intrinsecamente relacionado às regiões de climas tropical e subtropical. Isso porque tais climas são definidos pela variação de estações secas e chuvosas, sempre aliadas a elevadas temperaturas, condição favorável ao desenvolvimento de um intemperismo intenso e rápido. Dessa forma, os solos de comportamento laterítico são encontrados ao longo de todo o Mundo, justamente em tais regiões climáticas, conforme exemplificado na Figura 2.3 abaixo.

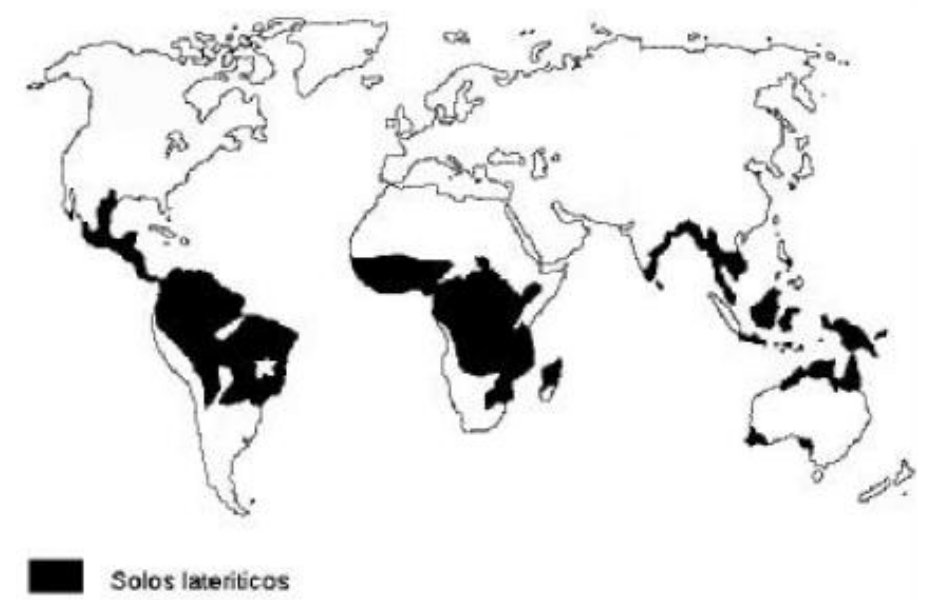

Figura 2.3: Distribuição Geográfica dos Solos Lateríticos ao longo do Mundo.

(Fonte: Santos, 2016) 
As características desse tipo de solo, contudo, são peculiares e diferem dos demais solos encontrados ao redor do Mundo. As classificações de solos utilizadas no Brasil são incorporadas e adaptadas de outras regiões, cujos solos apresentam gênese e comportamento distintos dos aqui encontrados (pois são oriundos de climas temperados). Na tentativa de utilização de tais classificações (denominadas tradicionais e que levam em consideração, basicamente, a granulometria e limites de Atterberg) aos solos tropicais de comportamento laterítico, os resultados não eram congruentes ao cenário local.

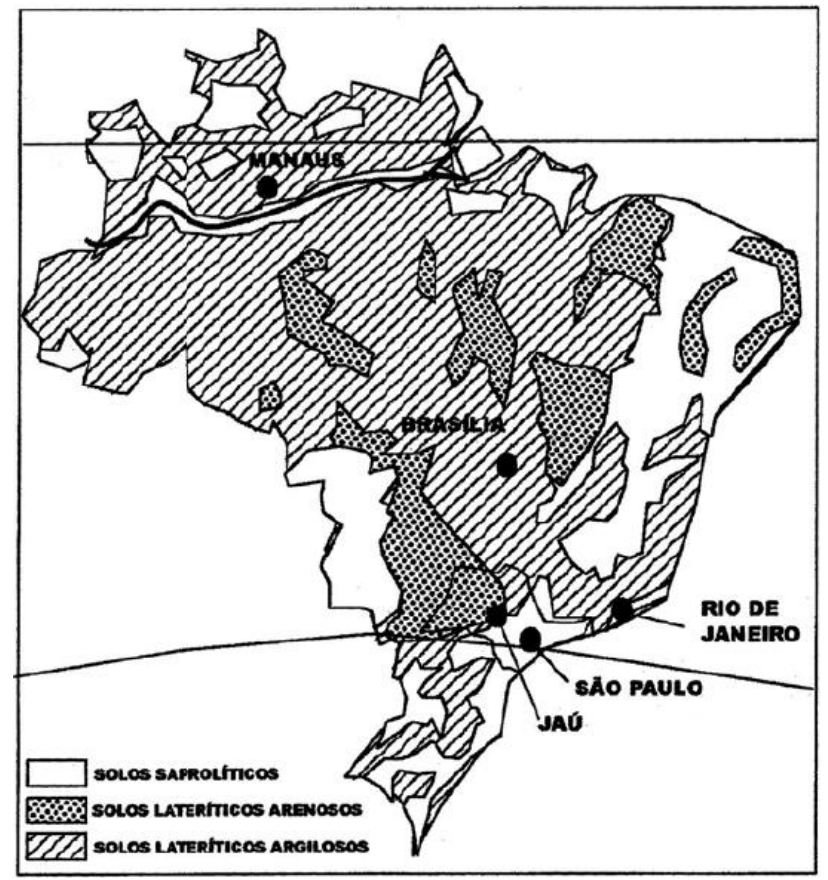

Figura 2.4: Distribuição geográfica de solos de comportamento laterítico ao longo do território nacional. Fonte: Delgado, 2002.

Segundo Nogami \& Villibor (1981), os métodos de classificações de solos difundidos em âmbito internacional não se aplicavam com sucesso aos solos tropicais, de comportamento laterítico, encontrados em nossa região. Dessa forma, foi então desenvolvido um método de classificação próprio aos solos com as características provenientes do intemperismo físico e químico sofridos em nosso clima tropical e subtropical, denominado MCT (abreviações de Miniatura, Compactado e Tropical).

De acordo com essa classificação, proposta por Nogami e Villibor (1981), os solos são classificados, conforme suas características, em duas grandes classes, sendo elas a dos solos lateríticos (L) e a dos solos não lateríticos $(\mathrm{N})$. A classe dos solos lateríticos (L) é subdividida em três grupos, o das areias lateríticas (LA), o dos solos arenosos lateríticos (LA') e o dos solos 
argilosos lateríticos (LG’). Já os solos não lateríticos (N) podem ser subdivididos de acordo com quatro grupos, sendo eles as areias não lateríticas (NA), os solos arenosos não lateríticos (NA'), os solos siltosos não lateríticos (NS') e solos argilosos não lateríticos (NG').

Para classificação de acordo com os grupos mencionados, é utilizado um ábaco de classificação, ilustrado na Figura 2.5, onde é necessária a determinação do índice $e$ ' e do coeficiente $c^{\prime}$. O coeficiente $c^{\prime}$ é obtido através de um ensaio denominado Mini-MCV. Já o índice $e$ 'é determinado através da seguinte expressão:

$$
e^{\prime}=\sqrt[3]{\frac{20}{d^{\prime}}+\frac{P_{i}}{100}}
$$

Onde $d$ ' corresponde ao coeficiente angular do trecho mais inclinado do ramo seco da curva de compactação correspondente a 12 golpes e $P_{i}$, à perda de peso característica do solo, obtida a partir do ensaio realizado com os corpos de prova que resultam do ensaio de MiniMCV. (FABBRI, 1994)

O coeficiente $c^{\prime}$, associado à argilosidade do solo, corresponde às abcissas do ábaco de classificação MCT e o índice $e$, que reflete o caráter laterítico do solo, corresponde às ordenadas. (SANTOS, 2006)

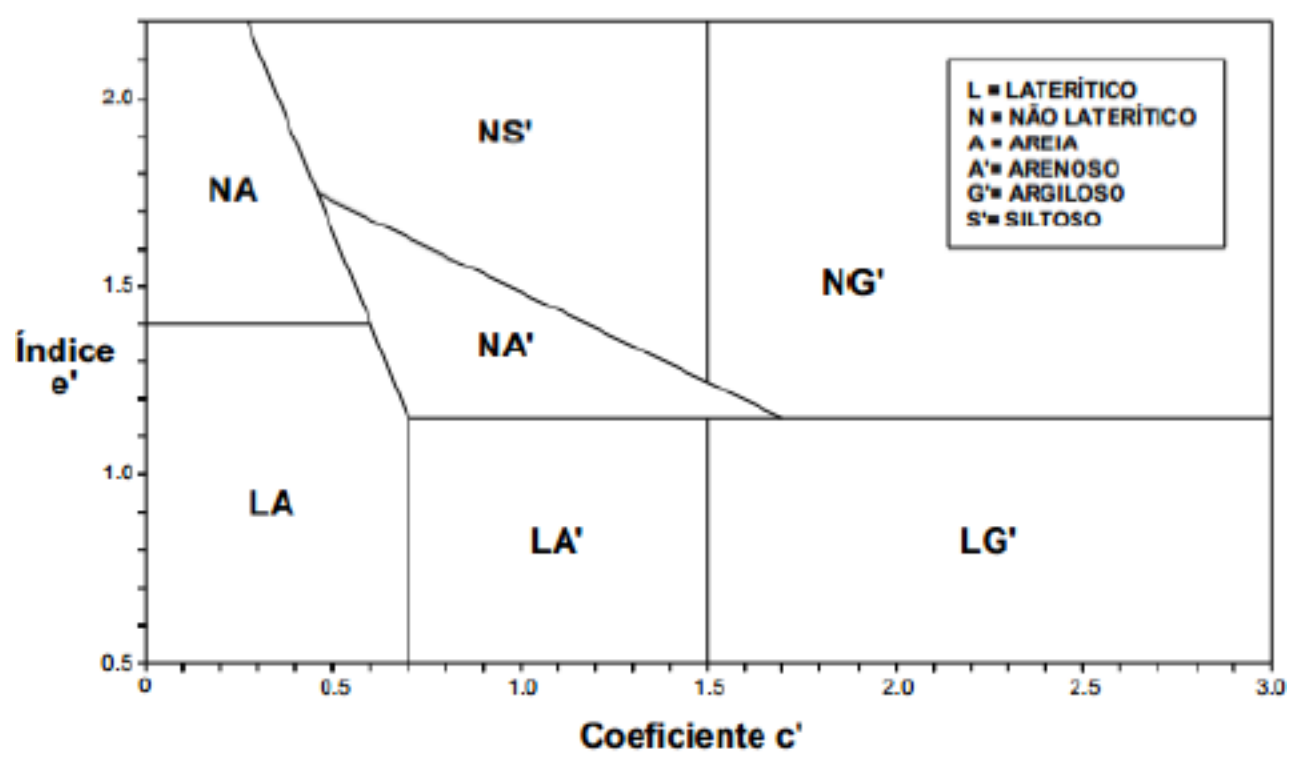

Figura 2.5: Ábaco de classificação MCT (Nogami \& Villibor, 1981).

A alternância de estações secas e chuvosas, culminando em um intenso intemperismo físico e químico, faz com que os materiais inconsolidados das camadas superficiais sofram o 
processo de lixiviação de seus finos, acarretando assim em uma estrutura com elevada porosidade e elevado coeficiente de permeabilidade. De acordo com Suarez (2008), a elevada porosidade natural e a baixa capacidade resistente são características desse tipo de solo.

Contudo, quando corretamente compactados, os solos de comportamento laterítico adquirem elevada resistência e apresentam baixas permeabilidade e perda de sua capacidade de suporte quando imersos em água.

\subsection{Solos Não Saturados}

A mecânica dos solos clássica é basicamente fundamentada no conceito de solos saturados (ou seja, aqueles que possuem seus vazios ocupados integralmente por água). Todavia, nem sempre o solo vem a se encontrar completamente saturado, podendo, inclusive em grande parte de sua vida, apresentar-se em condições muito aquém de sua saturação, sendo assim caracterizados como solos não saturados.

Em termos gerais, solos não saturados apresentam características hidro-mecânicas que diferem dos saturados e são compostos por três fases distintas, sendo elas a fase sólida (partículas sólidas do próprio esqueleto do solo), a fase líquida (constituída pela água e ar dissolvido) e a fase gasosa (composta pela mistura de ar e vapor d'água). A Figura 2.6 a seguir ilustra essas três fases distintas apresentadas por um solo não saturado.

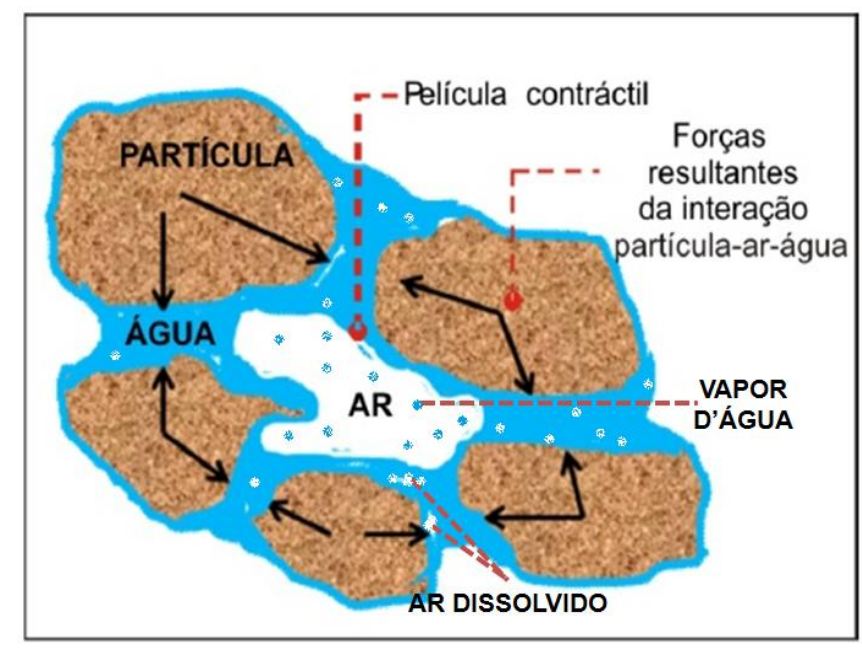

Figura 2.6: Ilustração das fases de um solo não saturado (adaptado de Bueno \& Vilar, 1979).

Diferentemente dos solos saturados (cujos vazios são integralmente preenchidos por água), os solos não saturados apresentam agora vazios preenchidos por ar e surge, em sua 
estrutura, uma interface ar-água que é semelhante a uma membrana de superfície curva. Devido ao diferencial de pressões presente nessa membrana (interface) e à tendência de equilíbrio das pressões entre o ar e a água, surgem tensões superficiais que tendem a aproximar as partículas sólidas.

Os poros com ar são geralmente compostos de canalículos de diâmetros reduzidos, assemelhados a tubos capilares. Por esses canalículos, ocorre a ascensão de água por capilaridade e surge uma tensão superficial que tende a equilibrar o sistema. Essa tensão superficial gerada pelo efeito capilar, associada à parcela de adsorção gerada pelo atrito entre as partículas (coesão), faz com que ocorra um aumento da tensão efetiva do solo, denominada sucção matricial.

Tal aumento de tensão efetiva provoca um acréscimo provisório de sua resistência, traduzido por um aumento da coesão por conta da atuação da sucção matricial. Esse acréscimo é dito provisório por conta de que, quando inundado, tal parcela adicional de resistência é anulada, uma vez que a tensão superficial antes atuante na interface ar-água deixa de existir.

\subsubsection{Sucção em solos não saturados}

Os conceitos de sucção têm sido estudados desde o século XIX, sendo a primeira tentativa de medi-la decorrente de Livingston (1906), que desenvolveu um estudo sobre os valores de sucções em um deserto para que pudesse, utilizando os princípios da osmose, inferir a capacidade dos solos em absorverem água para fins da agricultura. Shull (1916) é tido como o pioneiro em termos de desenvolvimento de técnicas de medidas de sucção, sendo seus métodos aprimorados por Gardner (1937), o qual deu origem à conhecida técnica do papel filtro. (MARINHO, 1997)

As variações climáticas e de índices pluviométricos às quais o solo fica submetido provoca uma constante variação do nível do lençol freático. A região situada acima do nível d'água fica sujeita, dessa forma, a constantes variações de umidade, sendo denominada zona vadosa. Tal zona subdivide-se em duas regiões, sendo uma adjacente ao nível do lençol freático e saturada por capilaridade (denominada franja capilar) e a outra, acima da franja capilar, que se encontra não saturada e é denominada zona ativa. Em ambas essas regiões, contudo, ocorre uma poropressão negativa, conforme ilustrado na Figura 2.7 a seguir. 

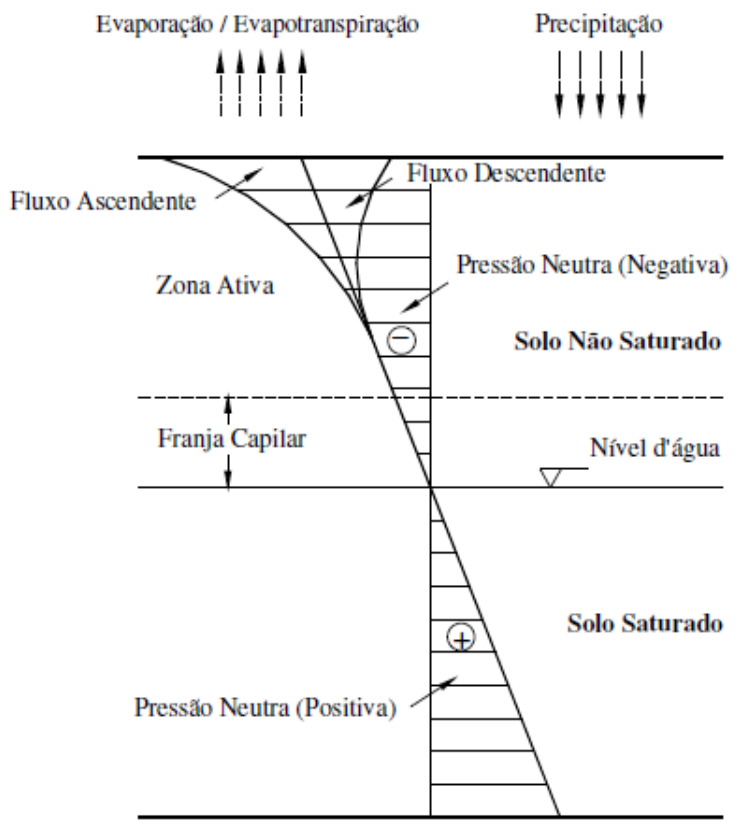

Figura 2.7: Variação da poropressão em um perfil estratigráfico.

Fonte: Rodrigues, 2009.

De acordo com Pereira (2013), a região superficial onde ocorrem variações da pressão neutra denomina-se região dinâmica pelo fato do fluxo de água sofrer alterações de acordo com as condições climáticas, fazendo com que ocorram variações em suas características mecânicas, tais como resistência, permeabilidade, compressibilidade e fluxo.

Na condição não saturada, a interação entre a água e as partículas sólidas pode ser mensurada pela avidez que o solo apresenta pela água. Essa avidez está diretamente relacionada a uma grandeza denominada sucção, a qual depende diretamente do teor de umidade que o solo apresenta, da sua mineralogia e da sua massa específica.

A sucção é representada, em termos totais, por uma parcela matricial $(s)$ e por uma parcela osmótica $(\pi)$. Segundo Rodrigues \& Carvalho (2015), a sucção matricial refere-se à pressão isotrópica negativa da água intersticial do solo devido às forças de capilaridade e de adsorção e é dependente da matriz do solo. Já a sucção osmótica é a parcela da sucção relacionada à diferença de concentração química de solutos da água no solo.

A sucção total de um solo é definida como a pressão manométrica (negativa, em relação à pressão externa de gás sobre a água do solo) que deve ser aplicada a um reservatório de água pura (à mesma cota e temperatura) de forma a manter-se o equilíbrio, através de uma 
membrana semipermeável (ou seja, que permite o fluxo de água, porém não o de solutos) entre a água do reservatório e a água do solo. (VILAR, 2002)

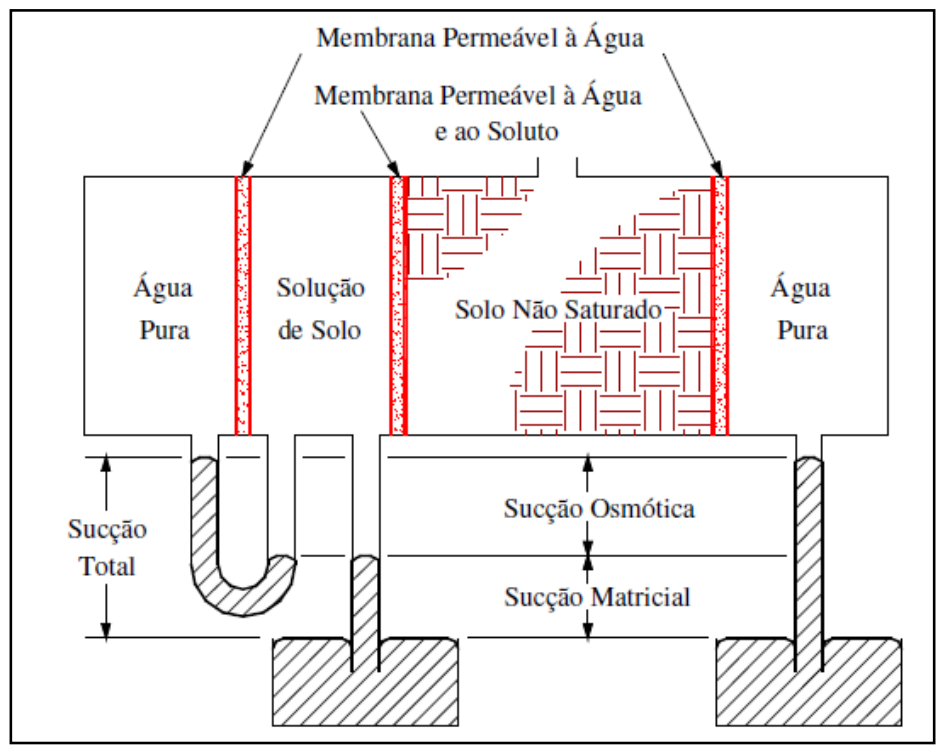

Figura 2.8: Esquema ilustrativo das sucções matricial, osmótica e total. Fonte: Rodrigues, 2009.

A sucção total $(\psi)$ depende do grau de saturação do solo e é inversamente proporcional ao mesmo. A sucção é aferida em termos de pressão, sendo geralmente representada em quilopascais $(\mathrm{kPa})$. O comportamento apresentado pelo solo, como sua resistência e deformabilidade é controlado, dentre outros fatores, pela pressão relativa (negativa) na água intersticial. Pressão relativa porque é expressa pela diferença entre a pressão atmosférica (pressão no ar) e a pressão na água intersticial (sucção matricial). (MARINHO, 1997)

Mesmo com a atuação da força gravitacional, existe a ascensão e armazenamento de água acima do lençol freático, causada pela avidez que um meio poroso não saturado apresenta pela água (expressa pela sucção). Na película contráctil formada pela interface ar-água, a resultante de atração das moléculas de água direciona-se para o interior da massa líquida, formando uma superfície não plana e côncava em relação ao ar.

A interface ar-água é representada, portanto, como uma membrana de superfície curva, onde atua uma tensão superficial denominada $T_{s}$, conforme ilustrado a seguir. 

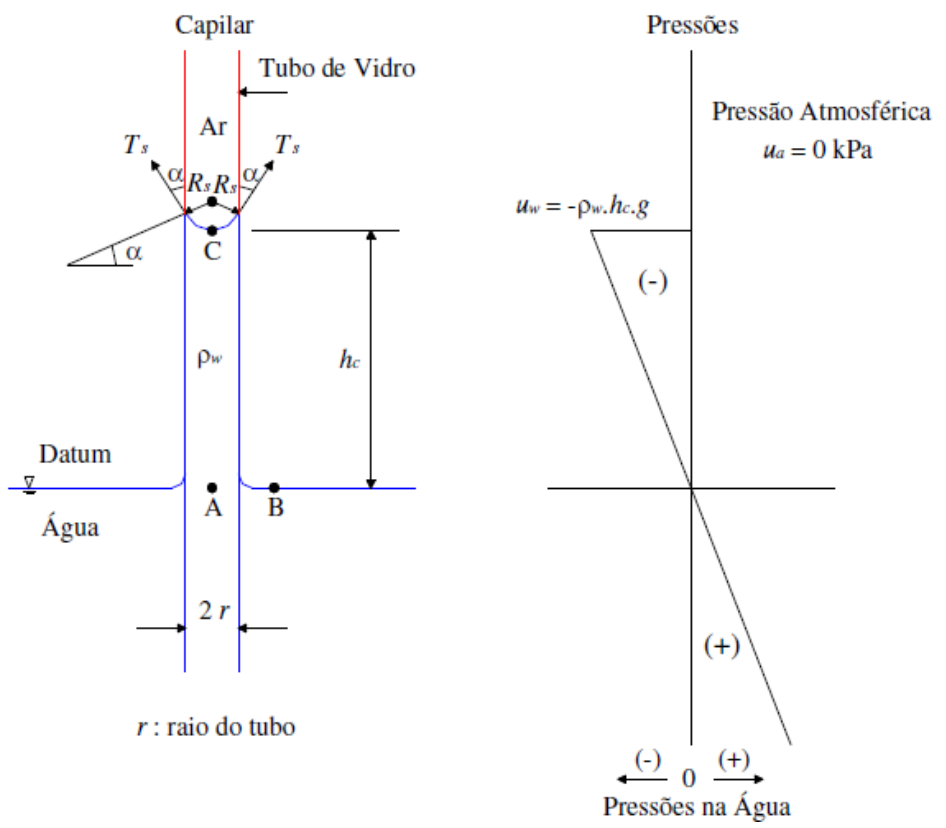

Figura 2.9: Esquema de ascensão de água por capilaridade (à esquerda) e diagrama de poropressões em um tubo capilar (à direita). Fonte: Rodrigues, 2009.

A sucção matricial é aferida como a diferença entre as pressões do ar e da água, representadas na Figura 2.9 pelo Ponto C. Desenvolvendo o equilíbrio de forças para o esquema apresentado, juntamente com um diferencial de pressão na interface ar-água no Ponto $\mathrm{C}\left(\Delta_{u}\right)$, é possível expressar o valor de sucção matricial em termos da altura de ascensão capilar $\left(h_{c}\right)$ :

$$
\begin{gathered}
2 \cdot \boldsymbol{\pi} \cdot \boldsymbol{r} \cdot \boldsymbol{T}_{s} \cdot \cos \alpha=\boldsymbol{\pi} \cdot \boldsymbol{r}^{2} \cdot \boldsymbol{h}_{\boldsymbol{c}} \cdot \boldsymbol{\gamma}_{w} \\
h_{c}=\frac{2 \cdot T_{s} \cdot \cos \alpha}{r \cdot \gamma_{w}}
\end{gathered}
$$

O raio de curvatura da membrana $\left(R_{s}\right)$ pode ser expresso, em função do raio do tubo capilar, como:

$$
R_{s}=\frac{r}{\cos \alpha}
$$

Para o caso de o soluto ser água pura, tem-se o ângulo $\alpha$ equivalente a zero graus e o raio de curvatura da membrana $R_{s}$ equivalente ao próprio raio $r$ do tubo capilar. De acordo com o Teorema de Laplace para o diferencial de pressões entre o ar e a água $(\Delta u)$, tem-se:

$$
\begin{gathered}
\Delta_{\boldsymbol{u}}=\frac{2 \cdot \boldsymbol{T}_{s}}{\boldsymbol{R}_{\boldsymbol{s}}} \\
u_{a_{c}}-u_{w_{c}}=\frac{2 \cdot T_{s}}{R_{s}} \rightarrow R_{s}=\frac{2 . T_{s}}{u_{a_{c}}-u_{w_{c}}}
\end{gathered}
$$


Do desenvolvimento da expressão 2.2, pode-se concluir que:

$$
\frac{2 . T_{s}}{u_{a_{c}}-u_{w_{c}}}=\frac{2 . T_{s}}{h_{c} \cdot \gamma_{w}} \rightarrow u_{a_{c}}-u_{w_{c}}=h_{c} \cdot \gamma_{w}
$$

Onde $u_{a_{c}}$ corresponde à pressão no ar no Ponto $\mathrm{C}$ (parte côncava da membrana), $u_{w_{c}}$ corresponde à pressão na água no Ponto $\mathrm{C}$ (parte convexa da membrana), $h_{c}$ é a altura de ascensão capilar e $\gamma_{w}$ é o peso específico da água.

\subsubsection{Retenção de água em um solo não saturado}

Uma representação muito comum para caracterização dos solos não saturados é a curva de retenção de água (comumente designada $S W R C$, "soil water retention curve"), que relaciona a quantidade de água presenciada em um solo com a sucção apresentada pelo mesmo. Cabe aqui salientar quanto ao termo "teor de umidade volumétrico" $(\theta)$, parâmetro comumente difundido na mecânica dos solos não saturados e que expressa a razão entre o volume de água intersticial $\left(V_{w}\right)$ e o volume total do solo $(V)$.

A confecção desta curva não está ainda padronizada, podendo ser expressa em termos de teor de umidade volumétrica $(\theta)$, teor de umidade gravimétrica $(w)$ ou grau de saturação $\left(S_{r}\right)$; sempre, contudo, em escala linear. Já a sucção pode ser tanto a total quanto a matricial, expressa em escala logarítmica ou linear, e podendo aparecer tanto no eixo das abscissas quanto no das ordenadas. Apesar de não haver uma padronização, a curva de retenção tem se mostrado uma interessantíssima ferramenta para caracterização de um solo não saturado e previsão de seu comportamento.

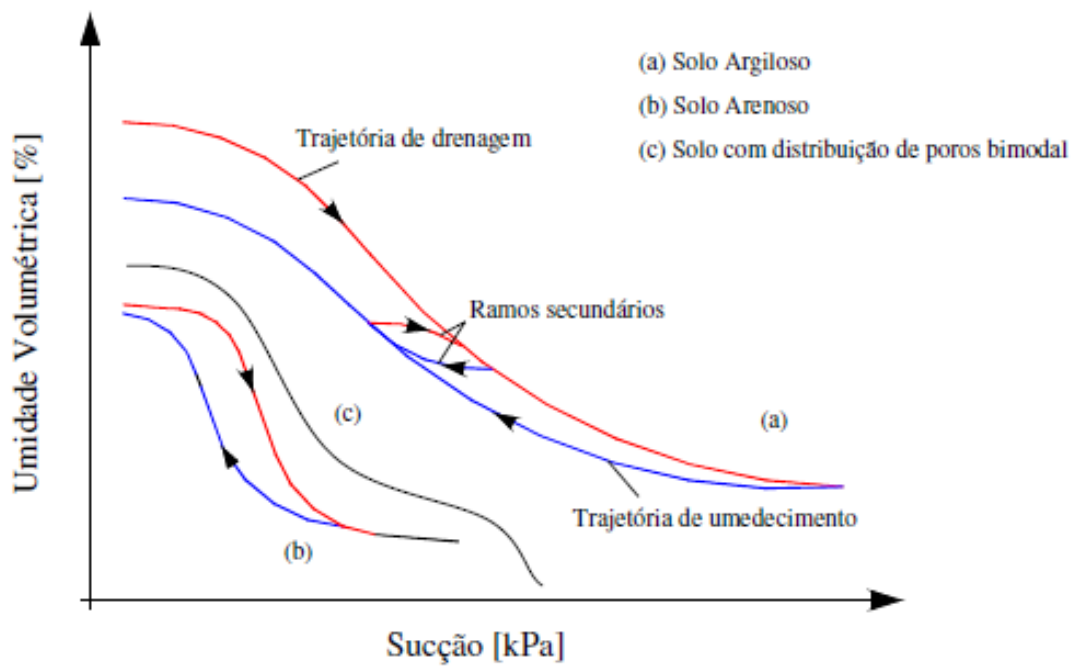

Figura 2.10: Curvas típicas de retenção de água para solos argilosos, arenosos e com distribuição de poros bimodal. Fonte: Rodrigues (2009). 
Na Figura 2.10 acima, a curva referente ao solo com distribuição bimodal apresenta dois pontos de inflexão (dois pontos de entrada de ar), referentes aos macroporos formados pelos vazios entre os agregados e/ou grãos maiores (a partir do qual o solo passa a não mais ser saturado) e aos microporos formados no interior dos agregados.

O formato apresentado pela curva de retenção de água de um solo é dependente da trajetória do ensaio. As trajetórias podem ser de secagem (ou drenagem ou ainda desidratação), de umedecimento ou então mista (secagem e umedecimento combinadas). $\mathrm{O}$ caminho referente aos ramos secundários confere o denominado ciclo de umedecimento e secagem, que ilustra a trajetória de sucção no campo ao longo das estações do ano.

Um aspecto importante em ser ressaltado é o de que, para maiores graus de compactação, menor é a variação do teor de umidade para diferentes sucções. Em um estudo realizado por Pereira (2013), diversos pontos de uma curva de compactação foram testados para medidas de sucção, a diferentes teores de umidade, para confecção de uma curva de retenção de água para cada situação. Os resultados desse estudo estão ilustrados na Figura 2.11 a seguir.

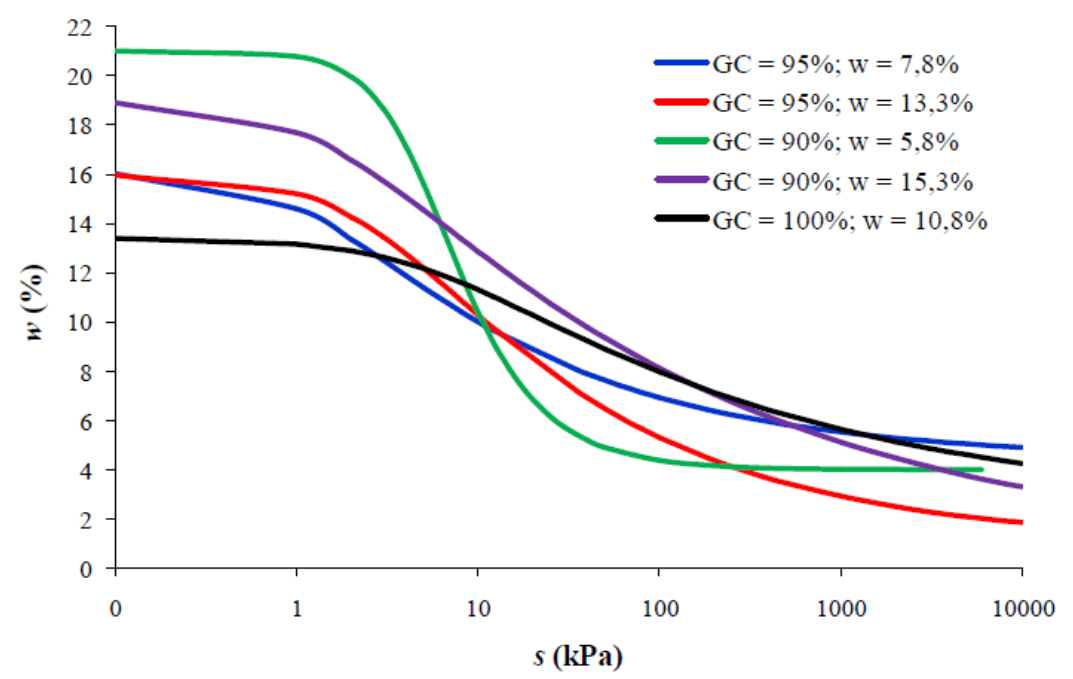

Figura 2.11: Curvas de retenção para diferentes graus de compactação e teores de umidade.

Fonte: Pereira, 2013.

Nota-se desse estudo que, mesmo os graus de compactação não variando tanto (10\% no máximo), ocorre uma grande diferença no comportamento apresentado por um mesmo solo, a depender do seu grau de compactação e teor de umidade inicial. Quando compactado conforme os parâmetros ótimos (curva de retenção referente a $\mathrm{GC}=100 \%$ ), é notório que o teor de umidade não apresenta tanta variação conforme alteração da sucção, visto pela baixa dispersão dos valores de teores de umidade nas ordenadas. Isso decorre do fato de o solo 
apresentar uma estrutura mais estável graças ao processo de compactação bem executado, ficando menos dependente da coesão proporcionada pela sucção matricial e, portanto, menos suscetível ao fenômeno de colapso.

Quanto maior o grau de compactação, menores a porosidade e o teor de umidade de saturação do solo. Assim, quanto mais compacto estiver o solo, a curva tende a concentrar-se em termos dos valores de teor de umidade (ou seja, assume uma forma mais achatada, com valores nas ordenadas mais uniformes). Conforme a compacidade do solo é diminuída, havendo uma maior presença de macroporos (graças ao maior índice de vazios que a estrutura apresenta), a curva adquire formas mais definidas e espaçadas no eixo das ordenadas, ficando, portanto, mais alongada verticalmente. (PEREIRA, 2013)

\subsubsection{Resistência ao cisalhamento de solos não saturados}

Pode-se dizer que um solo saturado passa para a condição não saturada quando o valor de sua sucção é igualado à pressão de borbulhamento (ou pressão de entrada de ar no solo). Ou seja, um solo passa a ser não saturado quando a pressão do ar eleva-se o suficiente para quebrar o menisco formado na interface do ar com a água e começa a penetrar no mesmo até que sejam formados os primeiros canais contínuos de ar no solo. Vale ressaltar que é possível, antes que seja atingida a pressão de borbulhamento, que ocorra a presença de ar no solo sob a forma de bolhas. Nessa condição (parcialmente não saturada ou de ar ocluso) é admitido que, em termos de resistência ao cisalhamento, o solo apresente comportamento análogo ao da condição saturada. (CAMPOS, 1997)

Em um solo saturado, a resistência ao cisalhamento não depende do critério de ruptura adotado, sendo expressa como uma função da tensão efetiva. Diversos foram os estudos e formulações de equações para predizer o comportamento de um solo não saturado em termos de sua resistência ao cisalhamento, tornando-se a mais conhecida a proposta por Bishop (1959), em que:

$$
\boldsymbol{\sigma}^{\prime}=\left(\boldsymbol{\sigma}-\boldsymbol{u}_{\boldsymbol{a}}\right)-\chi\left(\boldsymbol{u}_{\boldsymbol{a}}-\boldsymbol{u}_{\boldsymbol{w}}\right)
$$

Onde $\left(\sigma-u_{a}\right)$ equivale à tensão total líquida, $\left(u_{a}-u_{w}\right)$ equivale à sucção matricial e o termo $\chi$ refere-se a um parâmetro dependente do tipo e do grau de saturação do solo (podendo variar de zero até um). Apesar de ser expresso em função do grau de saturação, tal parâmetro não apresenta relação direta com o mesmo. A proposta de Bishop (1959) expressa de maneira 
satisfatória a resistência de um solo via um único parâmetro $(\chi)$, mas acaba por não descrever bem o comportamento do solo quanto à sua compressibilidade e deformações. Dessa forma, existem algumas limitações dessa equação para representação do comportamento de solos colapsíveis e expansivos, não sendo, portanto, utilizada para tais.

Devido a essa dificuldade de traduzir satisfatoriamente o comportamento do solo em termos de resistência, mas não em termos de deformações (compressibilidade), é que foram desenvolvidos estudos optando pela utilização das variáveis $\left(\sigma-u_{a}\right)$ e $\left(u_{a}-u_{w}\right)$, possibilitando a avaliação das variações da tensão total e pressão neutra. Com base nessa premissa, Fredlund $e t$ al. (1978) propuseram uma equação alternativa para a resistência ao cisalhamento dos solos não saturados, expressa por:

$$
\tau=c^{\prime}+\left(\sigma-u_{a}\right) \operatorname{tg} \phi^{\prime}+\left(u_{a}-u_{w}\right) \operatorname{tg} \phi^{b}
$$

Em que $c$ 'e $\phi$ ' são os parâmetro efetivos de resistência do solo na condição saturada e $\phi^{b}$ é o ângulo de atrito do solo com relação à sucção matricial e quantifica o aumento da resistência devido ao aumento da sucção. Diferentemente dos solos saturados, em que a envoltória de resistência é traçada em um plano, os solos não saturados têm sua envoltória contida em um espaço tridimensional, conforme ilustrado na Figura 2.12 a seguir.

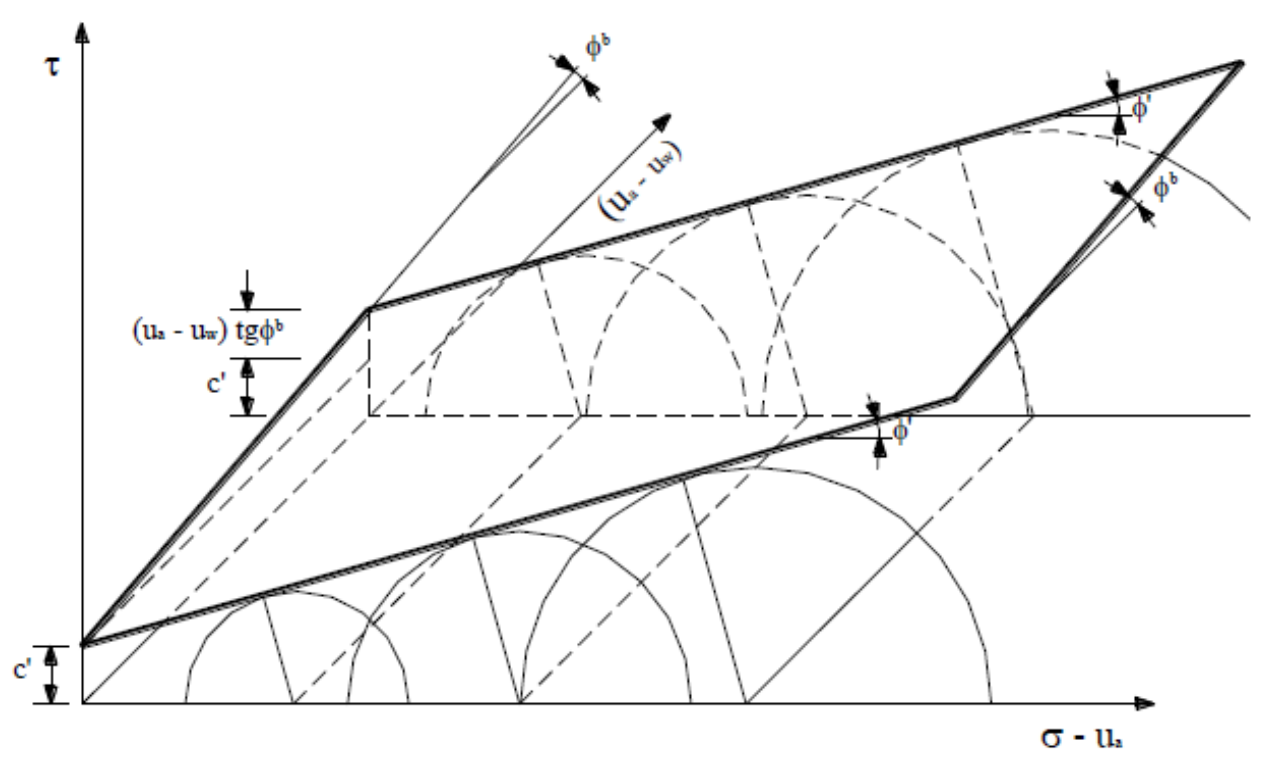

Figura 2.12: Envoltória de Resistência ao Cisalhamento para um solo não saturado. (Fredlund et al, 1978). 


\subsubsection{Métodos para determinação da sucção}

Devido à importância da sucção para o comportamento do solo (tanto hidráulico quanto mecânico), foram desenvolvidas diversas técnicas para possibilitar a determinação de tal grandeza (que, relacionada ao teor de umidade momentâneo, confere um ponto da curva de retenção de água).

Dentre os diversos métodos existentes para medidas de sucção em um solo, serão aqui mencionados alguns mais comumente encontrados. Marinho (1997) descreve detalhadamente acerca dos psicrômetros, tensiômetros (tradicional e especiais), papel filtro e da técnica de translação de eixos. Com exceção desses dois últimos, os demais ensaios são realizados para determinação da sucção em campo (in situ). Pereira (2013) apresenta algumas determinações de sucção em laboratório com as técnicas do papel filtro, da câmara de pressão e do funil de placa porosa para diferentes graus de compactação do solo. Será também brevemente comentado acerca do ensaio de porosimetria por injeção de mercúrio. Existem ainda outras técnicas, que não serão aqui detalhadas.

\subsubsection{Psicrômetros}

Os psicrômetros são transdutores térmicos (medidores de temperatura) em que a sucção é obtida através de uma curva de calibração que relaciona voltagem com valores de sucção. Pelo efeito Seebeck, gera-se uma corrente elétrica devida a indução de uma diferença de temperatura entre duas juntas de dois materiais condutores. Pelo efeito Peltier, a indução de uma junta úmida é feita através da passagem de corrente pelo sistema (termopar), que gera uma diferença de temperatura proporcional a umidade relativa do ar. Seu intervalo de medição varia de sucções equivalentes a $100 \mathrm{kPa}$ até aproximadamente $10 \mathrm{MPa}$.

\subsubsection{Tensiômetros}

Os tensiômetros são constituídos por um tubo conectado na parte inferior a uma pedra porosa (cuja entrada de ar é de aproximadamente $100 \mathrm{kPa}$ ) e na parte superior a um vacuômetro e uma tampa. O princípio básico de funcionamento baseia-se na tentativa do solo não saturado em absorver a água do interior do tubo através da pedra porosa instalada na sua base. Como a água do sistema não está livre para se mover por gravidade, o vacuômetro registra a pressão que o solo exerce para retirar a água do tensiômetro. Quanto menor o teor de umidade do solo, maior será a sua avidez pela água do tensiômetro, e, por conseqüência, maior a sucção registrada pelo vacuômetro. 

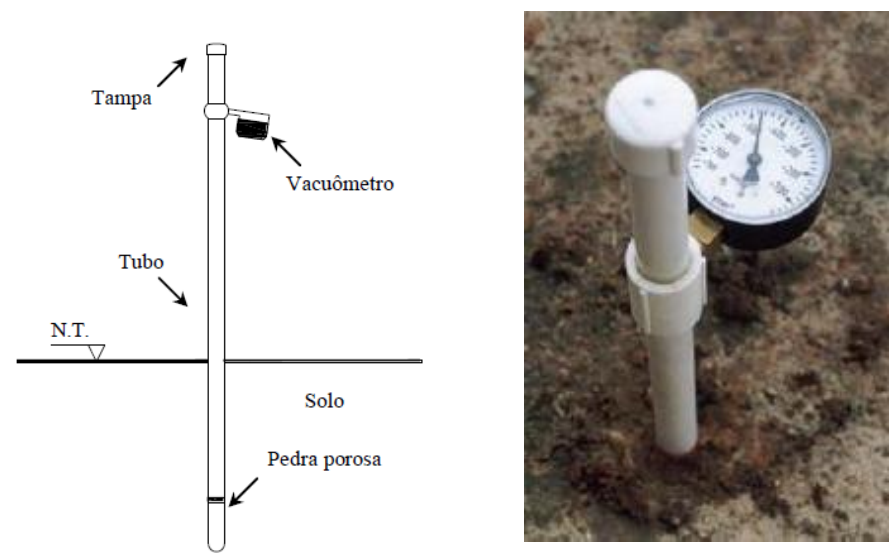

Figura 2.13: Esquema ilustrativo de um tensiômetro (à esquerda) e tensiômetro instalado em campo (à direita).

\subsubsection{Técnica do Papel Filtro}

Esta técnica é bastante difundida no meio técnico pela sua simplicidade. O método consiste em colocar um papel de características de retenção conhecidas num ambiente hermético juntamente com uma amostra de solo. Dado o contato entre o papel que é capaz de reter umidade e o solo, ocorre migração de água até estabelecer-se o equilíbrio de potencial. A determinação da sucção do solo é obtida mediante uma curva de calibração do papel.

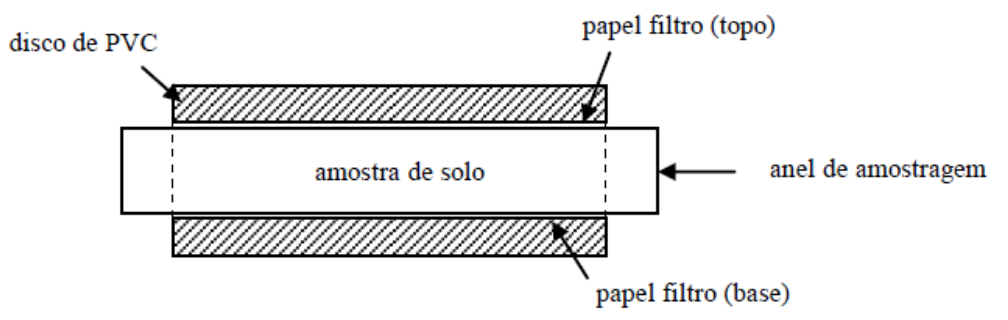

Figura 2.14: Esquema ilustrativo da montagem de um corpo de prova para ensaio com papel filtro.
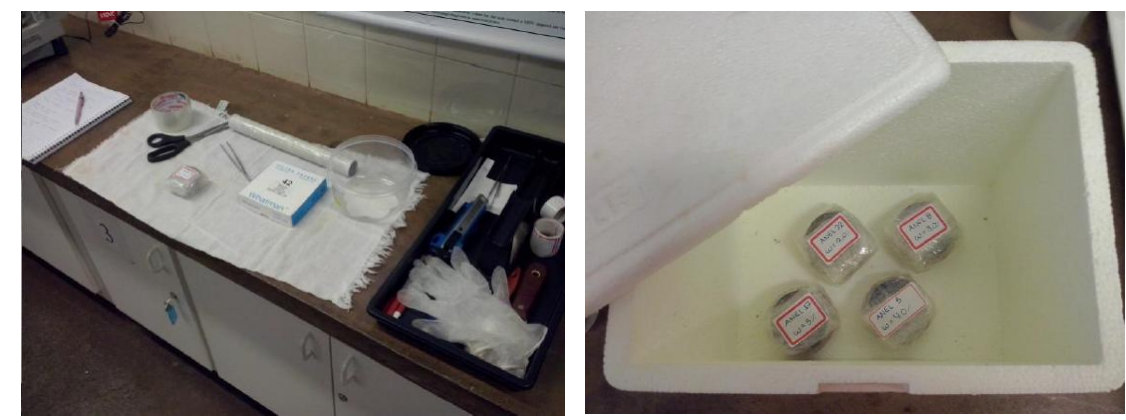

Figura 2.15: Procedimento de montagem do corpo de prova para determinação da sucção através da técnica do papel filtro. Fonte: Pereira, 2013. 


\subsubsection{Câmara de Pressão}

A câmara de pressão, também denominada de panela de pressão ou câmara de Richards é utilizada para determinação das características de retenção da água pelos solos. Tal equipamento consiste em uma câmara hermeticamente fechada e em cujo interior é fixada uma placa porosa de alta pressão de entrada de ar, a qual permite, dentro de certos limites, o fluxo de água, porém não o de ar. Por envolver a técnica de translação de eixos, tal placa é de suma importância para determinação do par umidade e sucção. Essa técnica consiste na alteração do referencial de pressão com o aumento da pressão de ar existentes nos espaços intergranulares do solo, alterando, portanto, a origem do eixo de pressão na água (VILAR, 2006).

Deve-se saturar a placa em água destilada e deairada por um período de 24 horas. Os corpos de prova são colocados em seu interior e é imposta uma pressão de entrada de ar na câmara equivalente à sucção desejada. O limite de trabalho fica por conta dessa pressão de entrada de ar que é capaz de dar início ao fluxo de ar através da placa e que pode atingir até 15 bar (1500 kPa). (PEREIRA, 2013).
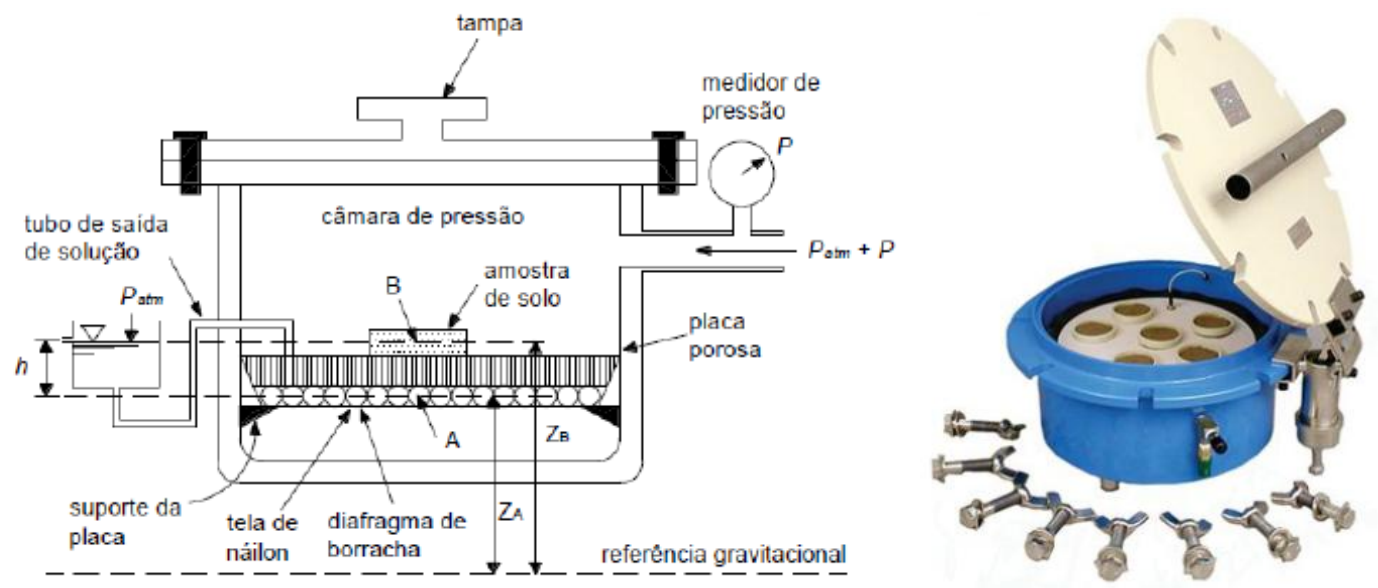

Figura 2.16: Esquema representativo de uma câmara de pressão (a) e ilustração de uma câmara de pressão com corpos de prova (b). Fonte: Pereira, 2013.

\subsubsection{Funil de Placa Porosa}

O Funil de Placa Porosa ou Funil de Haines é um equipamento constituído por um funil, provido de uma placa porosa e de um tubo, através do qual se impõem gradientes de altura (pela redução ou elevação do nível d'água de um reservatório simples acoplado ao funil ou pela abertura dos registros do tubo). 
Para imposição da sucção nos solos, o procedimento padrão é o seguinte: inicialmente coloca-se o corpo de prova saturado na superfície da placa porosa (também saturada), mantendo-se o nível do tubo flexível no topo da amostra ou mantendo-se fechado os registros do tubo; em seguida, o reservatório de água é rebaixado ou o registro é aberto em uma determinada altura de interesse, fazendo com que ocorra a drenagem de água do solo; após interrupção do fluxo de água (estabilização do corpo de prova), o solo é retirado para medição do seu teor de umidade.

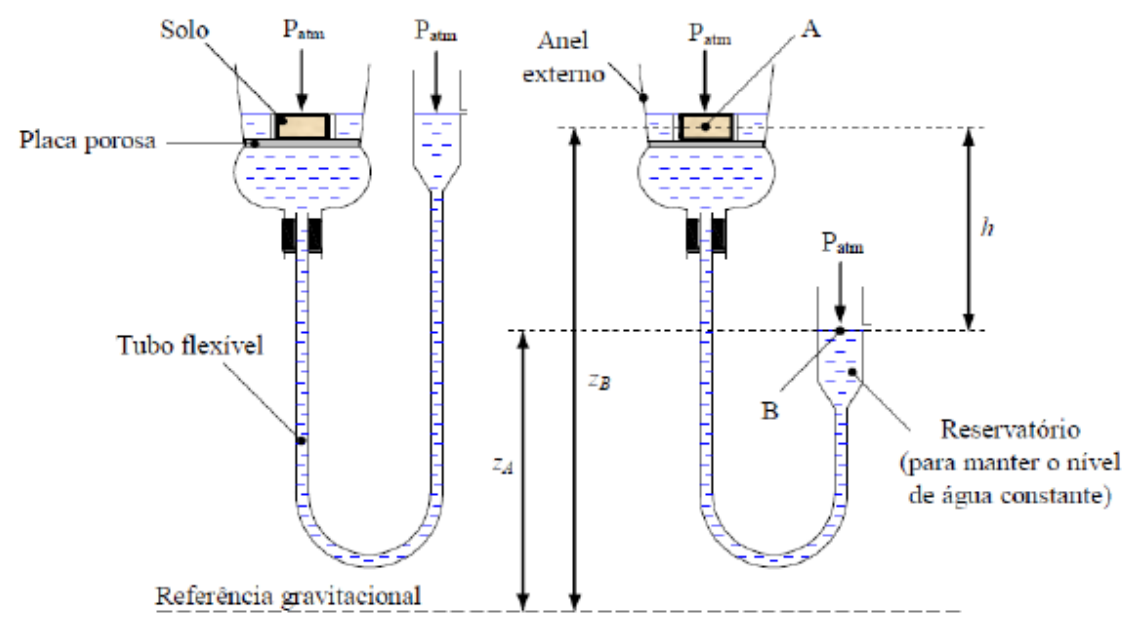

Figura 2.17: Esquema representativo de um Funil de Haines. Fonte: Pereira (2013) apud Libardi (1995).

\subsubsection{Porosimetria por Intrusão de Mercúrio}

Esta técnica baseia-se no princípio de que, a uma pressão atmosférica atuante apenas, o mercúrio não apresentará energia suficiente para conseguir penetrar nos poros do solo, sendo, portanto, necessária a atuação de uma pressão externa para possibilitar tal penetração. À medida que tal pressão externa é aplicada e o mercúrio consegue penetrar nos poros, o nível de mercúrio diminui e é possível assim saber o volume de poros ocupados pelo mesmo. A partir da pressão $P$ aplicada, calcula-se de maneira empírica a sucção e o teor de umidade do solo, sendo possível, assim, o traçado da curva de retenção de água no solo. (MASCARENHA et. al, 2008)

Uma vez que a sucção matricial e a parcela adicional de resistência por ela gerada são governadas pela distribuição de ar nos vazios do solo, torna-se fundamental o conhecimento da curva de distribuição desses vazios. (VILAR et. al, 1995) 
Com essa finalidade, os ensaios de porosimetria por intrusão de mercúrio são executados, introduzindo-se mercúrio sob pressão dentro dos poros do solo seco. Monitora-se ao longo de todo o ensaio o volume e a pressão de intrusão do mercúrio, sendo essa menor no início para preenchimento dos macroporos e aumentada gradativamente à medida que os poros vão sendo preenchidos. Correlaciona-se, através da equação de Young-Laplace, os dados obtidos do ensaio com o raio aproximado dos poros preenchidos. (GUTIERREZ, 2005)

\subsection{Solos Colapsíveis}

A água, em contato com o solo não saturado, pode agir de duas maneiras distintas: ou pela eliminação das forças capilares que proporcionam a parcela de resistência adicional temporária ao solo devido ao aumento da tensão efetiva (coesão que varia em função da sucção matricial) ou então pela redução da cimentação existente entre as partículas sólidas (VILAR, 1981).

Caso tais tensões capilares sejam anuladas, tanto pela saturação parcial ou total do solo, ocorrerá uma brusca diminuição da resistência do solo, tornando-o mais suscetível ao fenômeno de colapso (SOUZA, 1993).

Por definição, solos colapsíveis são solos altamente porosos e permeáveis que apresentam boas condições de resistência quando não saturados devido às tensões capilares (sucção), mas que podem apresentar consideráveis recalques quando inundados, devido à perda da sua parcela adicional de resistência proporcionada pela sucção matricial. Ou seja, se o teor de umidade for aumentado até um determinado valor limite (valor crítico, geralmente aquém da saturação), esses solos, submetidos a um determinado carregamento, sofrem uma repentina e considerável redução de volume. Essa redução decorre de uma espécie de colapso da estrutura do solo e, por isso, a denominação de solos colapsíveis.

Dessa forma, Cintra (1998) define que "são dois os requisitos básicos para o desenvolvimento da colapsibilidade em solos naturais: uma estrutura porosa, caracterizada por um alto índice de vazios, e a condição não saturada, representada por um baixo teor de umidade".

Em alguns casos, o carregamento necessário para gerar o fenômeno do colapso pode ser devido ao peso próprio da camada apenas, como em alguns solos do norte europeu. São os 
solos ditos verdadeiramente colapsíveis, formados em condições deficientes de umidade e que, quando vêm a ter seu teor de umidade aumentado por alguma razão, colapsam sem que haja nenhuma sobrecarga solicitante.

Contudo, esse não é o caso dos solos de nossa região, onde é necessário um carregamento mínimo para que seja desencadeado o colapso, denominado de "carga de colapso" (Cintra, 1995). Dessa forma, para que ocorra o fenômeno de colapso do solo, é necessário que sejam atingidos, simultaneamente, o teor de umidade equivalente à inundação do solo e uma carga no mínimo igual à carga de colapso do mesmo.

A norma brasileira de fundações, NBR 6122/2010, define solos colapsíveis como "solos que apresentam brusca redução de volume quando submetidos a acréscimos de umidade, sob a ação de carga externa" e alerta ainda quanto à consideração da possibilidade de ocorrência de encharcamento do solo devido a possíveis vazamentos de tubulações, elevação do lençol freático e entre outros.

De acordo com Collares (2002), solos colapsíveis possuem "uma estrutura macroporosa, onde as partículas se mantêm em equilíbrio meta-estável pela presença de um vínculo (cimentação e/ou sucção) capaz de proporcionar ao solo uma resistência adicional temporária".

É necessário ainda atentar-se para as estruturas a serem construídas e os danos admissíveis pelas mesmas, uma vez que os recalques diferenciais provenientes de um fenômeno de colapso podem causar danos irreparáveis às estruturas, comprometendo sua utilização. Na Figura 2.18 a seguir são ilustrados exemplos de danos estruturais presenciados graças ao fenômeno de recalque de colapso sofrido pela camada de solo solicitada.
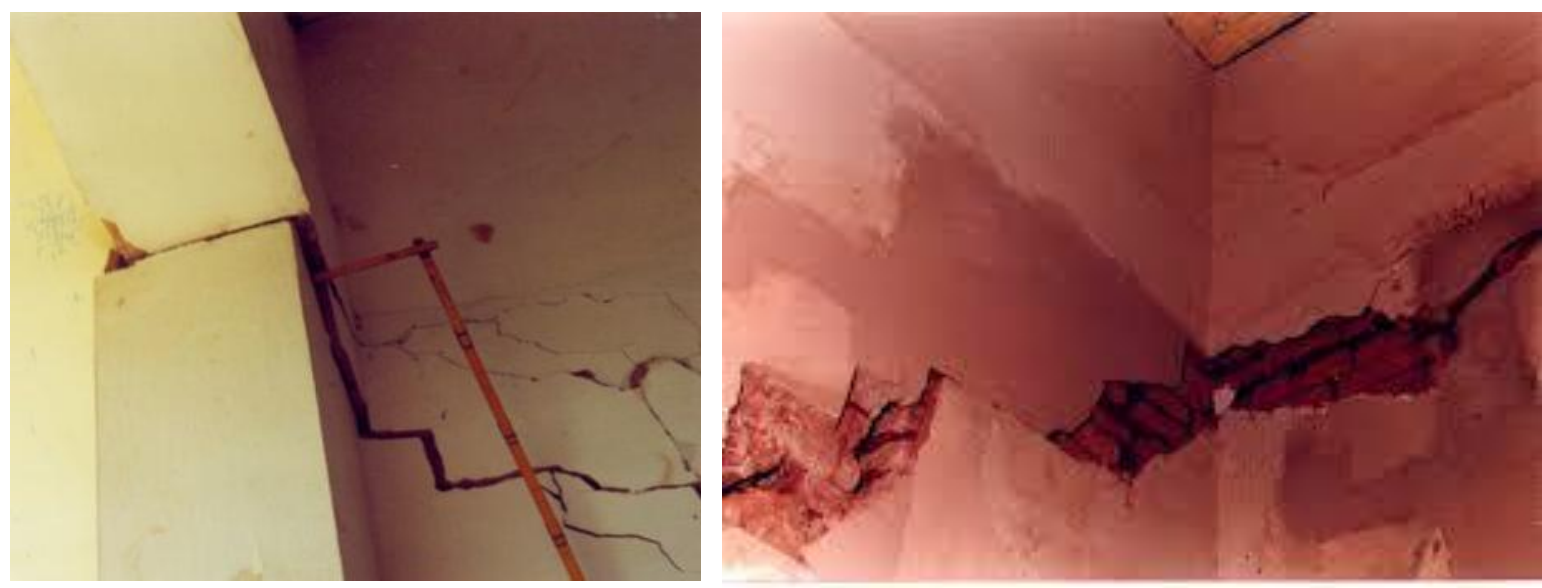

Figura 2.18: Ilustração de danos a edificações devido ao fenômeno de recalque de colapso. Fonte: Rodrigues \& Vilar, 2013. 
Os solos colapsíveis são comumente encontrados em diversas regiões do território nacional, requisitando especial atenção. Existem estudos e dados catalogados em diversos pontos do território nacional, conforme ilustrado na Figura 2.19 abaixo.

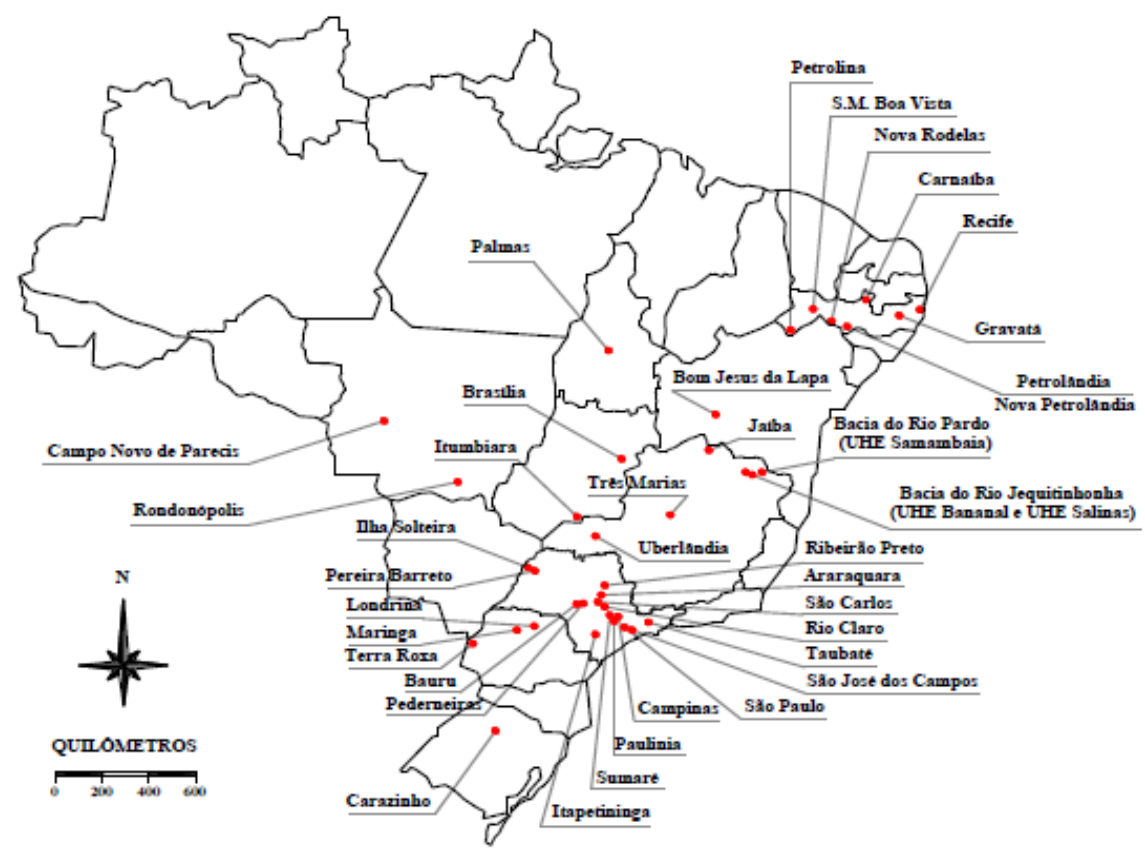

Figura 2.19: Distribuição de Solos Colapsíveis ao longo do Brasil. Fonte: Rodrigues \& Vilar, 2013.

\subsubsection{Ensaios Edométricos}

De acordo com Cintra \& Aoki (2009), o fenômeno referente ao colapso pode ser reproduzido em laboratório através dos ensaios edométricos, com inundação artificial do solo a um determinado estágio de carregamento, conforme ilustrado na Figura 2.20 abaixo.

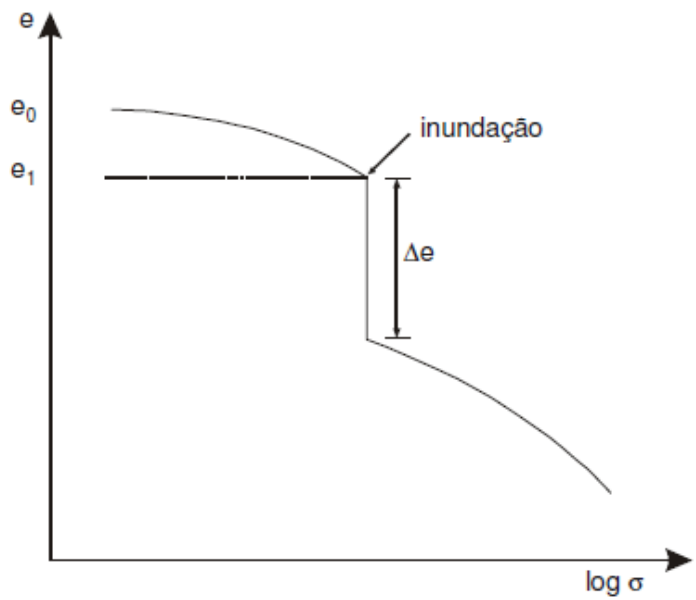

Figura 2.20: Ensaio edométrico em laboratório para reprodução do efeito de colapso. Fonte: Cintra \& Aoki, 2009. 
A maioria dos ensaios de laboratório para caracterização de solos colapsíveis provém da realização dos ensaios edométricos simples e duplos propostos por Jennings e Knight (1975). Os ensaios edométricos simples correspondem àqueles com um único corpo de prova, inundado em uma determinada carga de interesse. Já os edométricos duplos (ou gêmeos) são aqueles nos quais dois corpos de prova idênticos são ensaiados simultaneamente, sendo um deles na condição não inundada e o outro com inundação prévia ao ensaio. (CASTRO et al., 2017)

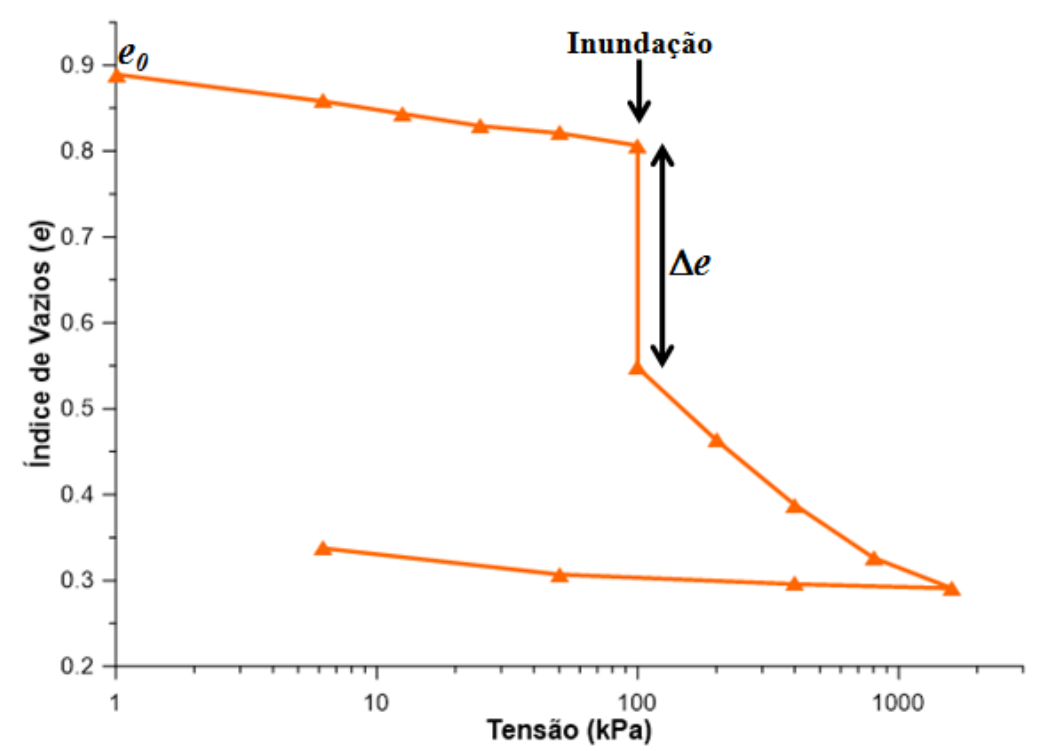

Figura 2.21: Ensaio edométrico simples.

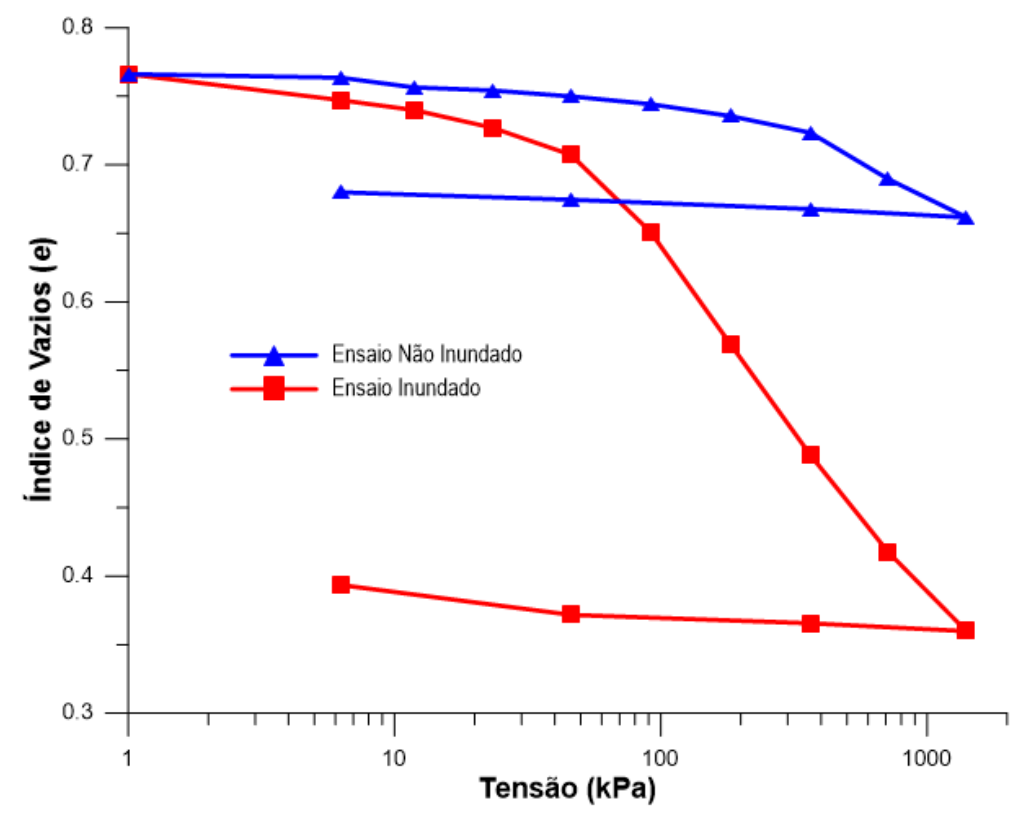

Figura 2.22: Ensaio edométrico duplo. 
Jennings e Knight (1975) sugerem o cálculo do denominado Potencial de Colapso (PC) para mensuração do deslocamento provocado pela inundação do solo, através da seguinte expressão:

$$
P C=\frac{\Delta e}{1+e_{0}}
$$

$\mathrm{Na}$ qual $\Delta e$ corresponde à variação do índice de vazios proveniente da inundação a uma determinada tensão e $e_{0}$ corresponde ao índice de vazios inicial do ensaio. $\mathrm{O}$ ensaio consiste em manter a inundação por um período de 24 horas e então medir o potencial de colapso. A vantagem do edométrico duplo perante o edométrico simples é justamente o da possibilidade de obtenção do potencial de colapso para qualquer tensão de interesse (ao passo que no simples o potencial de colapso é obtido apenas para a tensão em que foi realizada a inundação). Os autores ainda classificam a gravidade apresentada pelo efeito do colapso para obras de engenharia de acordo com intervalos do potencial de colapso, $P C$, de acordo com a Tabela 2.1 a seguir.

Tabela 2.1: Gravidade dos problemas ocasionados pelo efeito de colapso de acordo com o potencial de colapso proposto por Jennings e Knight (1975). Fonte: Motta, 2006.

\begin{tabular}{|c|c|}
\hline $\boldsymbol{P C}(\boldsymbol{\%})$ & Gravidade dos Problemas \\
\hline 0 a 1 & Sem problemas \\
\hline 1 a 5 & Problema moderado \\
\hline 5 a 10 & Problemático \\
\hline 10 a 20 & Problema grave \\
\hline$>20$ & Problema muito grave \\
\hline
\end{tabular}

Luttenegger \& Saber (1988) definiram o potencial de colapso através de um ensaio onde carrega-se a amostra até uma tensão de $300 \mathrm{kPa}$ (ou outra tensão mais adequada), na qual a mesma é inundada e as deformações são registradas até a sua estabilização. Segundo os autores, o potencial de colapso ( $I$ ) é então definido por:

$$
I=\frac{\Delta_{e_{c}}}{1+e_{i}}
$$

Onde $\Delta e_{c}$ corresponde à variação do índice de vazios proveniente da inundação a uma tensão de $300 \mathrm{kPa}$ (ou outra tensão mais adequada) e $e_{i}$ corresponde ao índice de vazios antes da inundação. Uma noção da gravidade do problema associada ao potencial de colapso $(I)$ é expressa na Tabela 2.2 a seguir. 
Tabela 2.2: Gravidade dos problemas ocasionados pelo efeito de colapso de acordo com o potencial de colapso proposto por Luttenegger \& Saber (1988). Fonte: Collares, 2002.

\begin{tabular}{|c|c|}
\hline $\boldsymbol{I}(\boldsymbol{\%})$ & Gravidade dos Problemas \\
\hline 2 & Leve \\
\hline 6 & Moderada \\
\hline 10 & Alta \\
\hline
\end{tabular}

Os ensaios edométricos, contudo, são qualitativos e servem apenas para conferência de uma noção quanto à colapsibilidade do solo, pois os ensaios são realizados em uma amostra de dimensões reduzidas, com um elevado confinamento (fornecido pelo anel metálico rígido), submetida a elevados carregamentos e cuja inundação é feita de maneira demasiadamente brusca, não representando idealmente as condições de campo.

Outro fator importante refere-se ao caso da perturbação na preparação de amostras deformadas, mesmo que tentando reproduzir os parâmetros encontrados em campo (grau de compactação e teor de umidade). O solo in situ sofreu, ao longo de sua vida, diversas trajetórias de secagem e umedecimento que resultaram em cimentações que fornecem uma parcela adicional de resistência. Além disso, a distribuição dos macroporos em sua matriz confere certas tensões superficiais que também aumentam a resistência provisoriamente e que não são exatamente reproduzidas em uma amostra em laboratório.

Somando esses fatores às perturbações devidas ao peneiramento, destorroamento, umedecimento, compactação e entre outros processos, decorre que os resultados de amostras indeformadas diferem consideravelmente dos referentes às deformadas. Um exemplo do descrito acima pode ser ilustrado na Figura 2.23 abaixo.

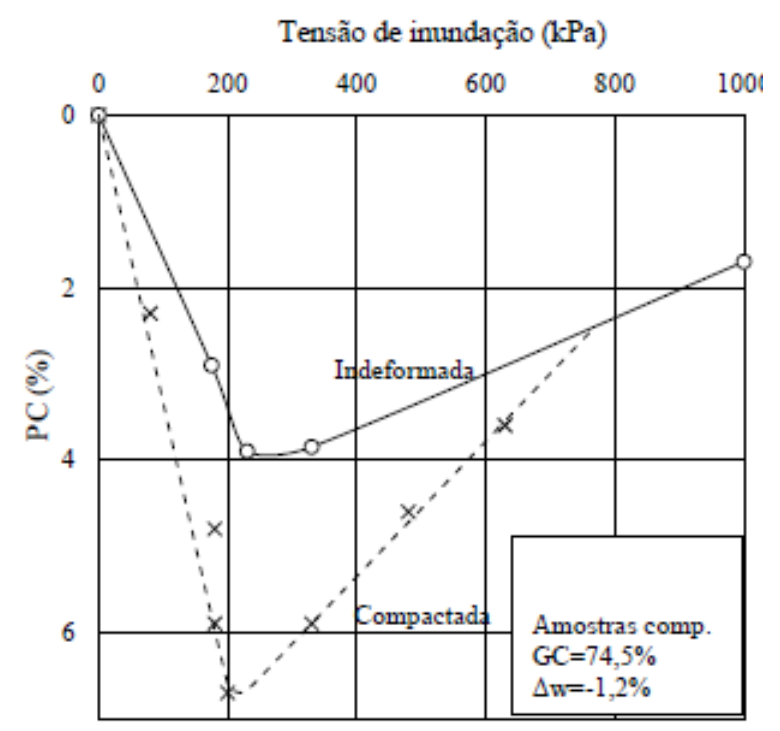

Figura 2.23: Diferença dos potenciais de colapso referentes a amostras indeformadas comparadas às compactadas. Fonte: Ferreira \& Monteiro, 1985. 
Cabe ainda salientar quanto à diferença entre colapso do solo e adensamento da camada. O colapso é traduzido pela expulsão do ar que antes havia dentre a matriz do solo (quando em condição não saturada) devido à sua inundação, sob uma mesma carga aplicada, e ocorre de maneira abrupta (instantânea). O colapso nada mais é que um problema de resistência traduzido em uma deformação acentuada. O estado de equilíbrio do solo é afetado pelo umedecimento e o mesmo então se reestrutura para buscar um novo equilíbrio, reestruturação essa traduzida em uma brusca redução de volume dos macroporos antes estáveis. Já o fenômeno de adensamento refere-se à saída gradual da água (tão mais lenta quanto menor o coeficiente de permeabilidade do solo) devido a um acréscimo de carregamento sofrido pelo solo (instantaneamente traduzido em excesso de poropressão).

\subsubsection{Ensaios de Prova de Carga}

Analogamente aos ensaios edométricos de laboratório, pode-se proceder a inundação antes do início da prova de carga (ensaio com inundação prévia) ou então realizá-la durante a execução do ensaio, a um determinado carregamento.

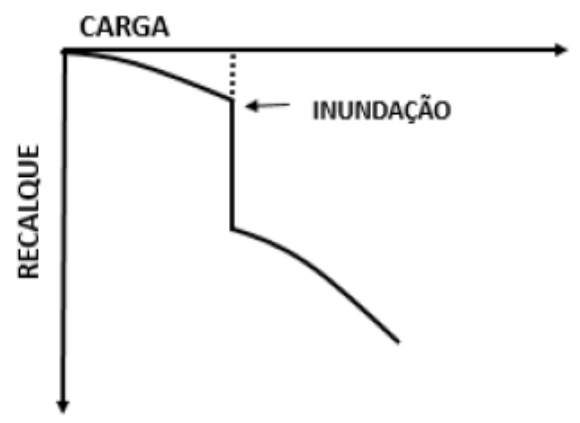

Figura 2.24: Curva carga $x$ recalque de um ensaio de prova de carga realizado com inundação durante a execução do ensaio, a um determinado nível de carregamento. Fonte: Cintra (1995).

No caso do ensaio de prova de carga com inundação previa do terreno, considera-se que o colapso não se manifeste por um recalque abrupto (uma vez que não é presenciado o trecho retilíneo vertical da curva carga x recalque como no ensaio com inundação durante a execução), mas sim pelo aumento da deformabilidade e diminuição da carga de ruptura, conforme ilustrado na Figura 2.25 a seguir. 


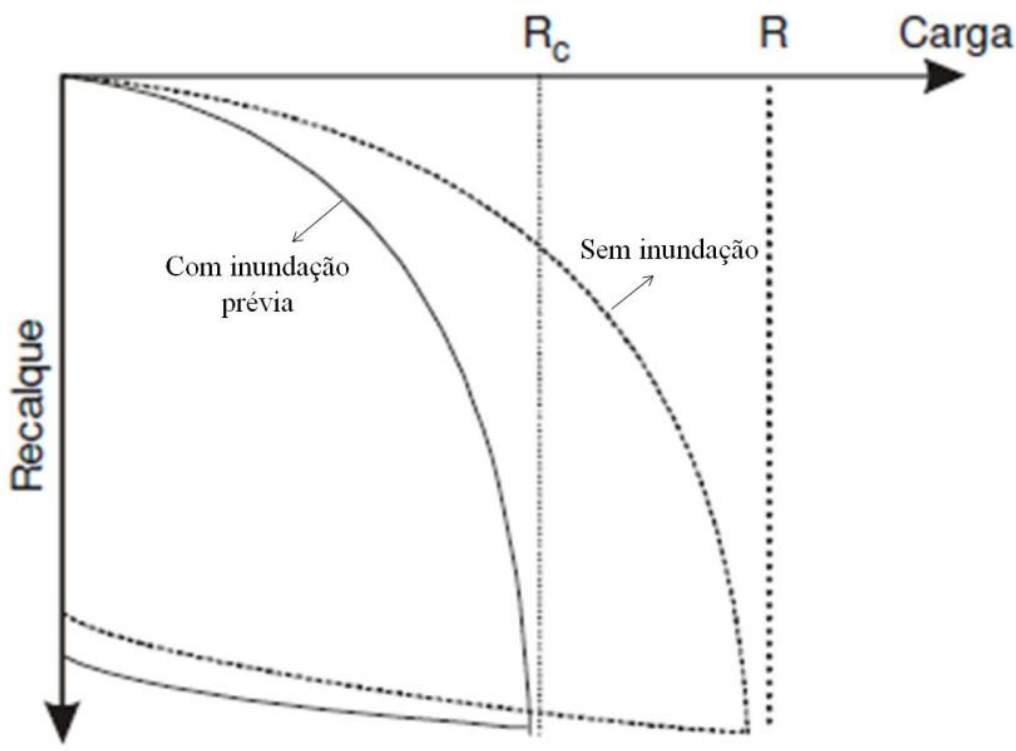

Figura 2.25: Carga de colapso determinada através de ensaio de prova de carga com inundação prévia do solo. Adaptado de Cintra (2004).

Segundo Cintra \& Aoki (2009), a capacidade de carga de uma fundação é diretamente dependente da sucção matricial e a condição mais crítica possível corresponde à de sucção matricial nula (solo inundado), na qual a capacidade de carga atinge seu valor mínimo. Além disso, os autores aconselham a realização do ensaio de prova de carga com pré-inundação do terreno para a determinação experimental da carga de colapso.

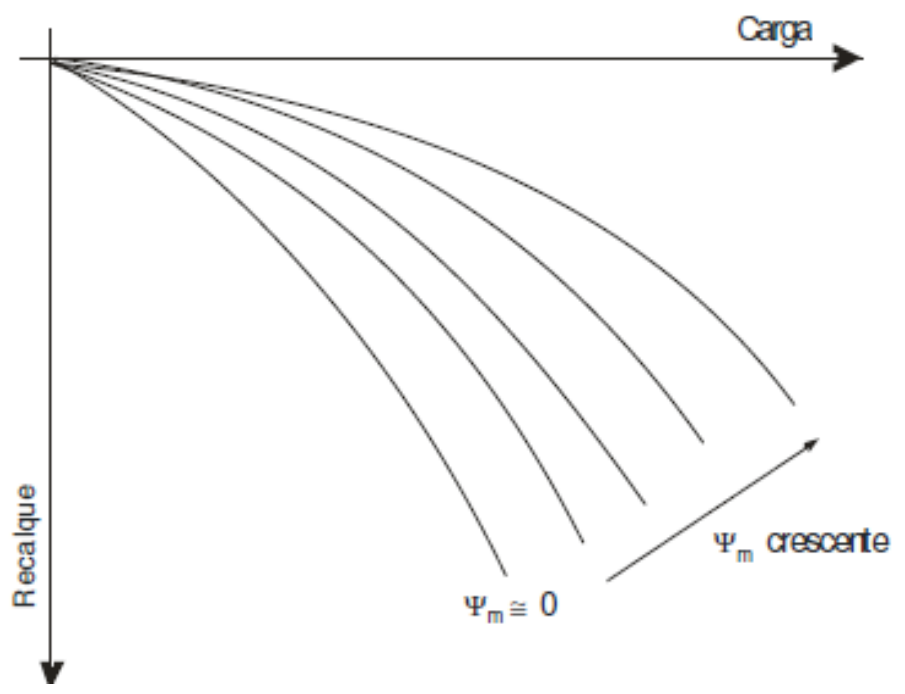

Figura 2.26: Curvas carga $x$ recalque de acordo com variações na sucção matricial. Fonte: Cintra (2004). 


\subsubsection{Critérios de Identificação de Solos Colapsíveis.}

Devido à importância e instabilidade dos solos colapsíveis, tornou-se fundamental o desenvolvimento de critérios para identificação dos mesmos. Apesar de vários serem disponibilizados na literatura, tais critérios apresentam a limitação de serem aplicáveis aos solos regionais a partir dos quais foram desenvolvidos, podendo apresentar discrepâncias quando adotados para outros solos de outras localidades. Ainda assim, é válido o conhecimento dos mesmos para possibilitar a noção acerca da colapsibilidade de um solo sem a necessidade de realização de ensaios mais elaborados.

\subsubsection{Critérios baseados nos Índices Físicos e Limites de Atterberg}

Para classificação da colapsibilidade de um solo são ilustrados a seguir alguns critérios encontrados na literatura, utilizando para isso alguns índices físicos e os limites de liquidez e plasticidade.

Tabela 2.3: Critérios de Identificação de Colapso. Adaptado de Collares (2002) e Freitas (2016).

\begin{tabular}{|c|c|c|}
\hline Critério & Expressão & Considerações \\
\hline Critério de Denisov (1951) & $k=\frac{e_{L}}{e_{0}}$ & $0,5<k<0,75 \rightarrow$ Solos Colapsíveis \\
\hline $\begin{array}{c}\text { Critério de Priklonskij } \\
(1952)\end{array}$ & $k=\frac{L L-w_{0}}{L L-L P}$ & $\begin{array}{c}k<0 \rightarrow \text { Solos Altamente Colapsíveis } \\
k \geq 0,5 \rightarrow \text { Solos Não Colapsíveis }\end{array}$ \\
\hline Feda (1966) & $K I=\frac{w_{0} / S_{r o}-L P}{L L-L P}$ & $K I<0,85 \rightarrow$ Solos Colapsíveis \\
\hline Gibbs e Bara (1967) & $k=\frac{w_{s a t}}{L L}$ & $k>1 \rightarrow$ Solos Colapsíveis \\
\hline Kassif \& Henkin (1967) & $k=\gamma_{d} \cdot w$ & $k<15 \rightarrow$ Solos Colapsíveis \\
\hline
\end{tabular}

Onde: $e_{L}$ é o índice de vazios correspondente ao limite de liquidez, $e_{0}$ é o índice de vazios natural, $L L$ e $L P$ são os limites de liquidez e plasticidade, $w_{0}$ é o teor de umidade natural, $S r_{0}$ é o grau de saturação natural, $w_{\text {sat }}$ é o teor de umidade saturado, $\gamma_{d}$ refere-se ao peso específico seco e $w$ é o teor de umidade. 


\subsubsection{Critério baseado no teor de finos}

Em um estudo, comentado por Collares (2002), houve a análise da probabilidade de colapso que um solo loéssico de Iowa apresentaria de acordo com a fração argila apresentada em sua granulometria, conforme ilustrado na Tabela 2.4 a seguir.

Tabela 2.4: Probabilidade de Colapso em função do teor de finos. (Fonte: Collares, 2002).

\begin{tabular}{|c|c|}
\hline Teor de Finos (\%) & Probabilidade de Colapso \\
\hline Inferior a 16 & Alta Probabilidade \\
\hline 16 a 24 & Provavelmente Colapsível \\
\hline 24 a 32 & Probabilidade menor que 50\% \\
\hline Superior a 32 & Geralmente não Colapsível \\
\hline
\end{tabular}

\subsubsection{Critério baseado em ensaio CPT}

A partir do ensaio de perfilagem CPT (Cone Penetration Test) é possível a estimativa de um coeficiente de colapso $\left(K_{w}\right)$ através da relação entre resistência a penetração do cone em solo natural pela resistência do mesmo em solo saturado. A partir de tal coeficiente, é possível então obter a noção da colapsibilidade apresentada pelo solo em questão.

\subsection{Técnicas de Melhorias de Solos}

Devido, portanto, a tal instabilidade apresentada pelos solos colapsíveis, uma das soluções comumente adotadas na prática refere-se à utilização de fundações profundas, cuja superfície resistente esteja localizada em camadas mais profundas e resistentes. Todavia, tal solução acaba, geralmente, por não ser a mais econômica, onerando a obra como um todo.

Quando a adoção de fundações profundas acaba por não ser viável, opta-se então pela utilização de alguma técnica que vise a melhoria das camadas menos resistentes do solo, podendo, em alguns casos, até mesmo ocorrer a remoção completa da camada e posterior execução de um aterro antrópico de características conhecidas.

Referente aos solos colapsíveis, existem também as técnicas de pré-inundação ou inundação controlada (em que a camada colapsível é umedecida para que o colapso seja 
minimizado), a de estabilização química (que envolve a redução do teor de umidade e o efeito de cimentação no interior da estrutura do solo, aumentando, portanto, sua resistência ao colapso) e a mais comumente difundida técnica de compactação do solo. Mais detalhes sobre as mesmas podem ser encontrados no estudo realizado por Freitas, 2016.

\subsection{Compactação do Solo}

Segundo Pinto (2009), a compactação do solo é a sua densificação, por meios mecânicos ou manuais, visando diminuir a sua permeabilidade, índice de vazios e assim aumentar sua massa específica seca e capacidade resistente. Credita-se o pioneirismo da técnica de compactação ao engenheiro Proctor que, em 1933, mostrou que, ao aplicar-se certa energia de compactação, a massa específica resultante seria função do teor de umidade apresentado pelo solo.

De acordo com Hogentogler (1937), a curva de compactação pode ser subdivida em quatro estágios distintos: o de hidratação, o de lubrificação, o de inchamento e o de saturação. $O$ primeiro estágio, de hidratação, refere-se ao envolvimento das partículas sólidas por uma fina camada de água adsorvida. $\mathrm{O}$ atrito entre as partículas fica reduzido e é possível um rearranjo estrutural das partículas sólidas.

No estágio subseqüente, de lubrificação, o teor de umidade já é suficiente para que a água presente sirva como um lubrificante às partículas sólidas, que conseguem novamente se rearranjar de forma a deixar a estrutura ainda mais densa.

No terceiro estágio, de inchamento, o teor de umidade ótimo já foi atingido e ultrapassado; não ocorre mais expulsão de ar, mas sim um aumento de volume das partículas sólidas devido à umidade, diminuindo assim o peso específico.

Por fim, o último estágio, de saturação, o solo não apresenta mais ar em sua estrutura praticamente, com seu grau de saturação próximo a $100 \%$ e o excesso de água dificulta o rearranjo das partículas sólidas. 


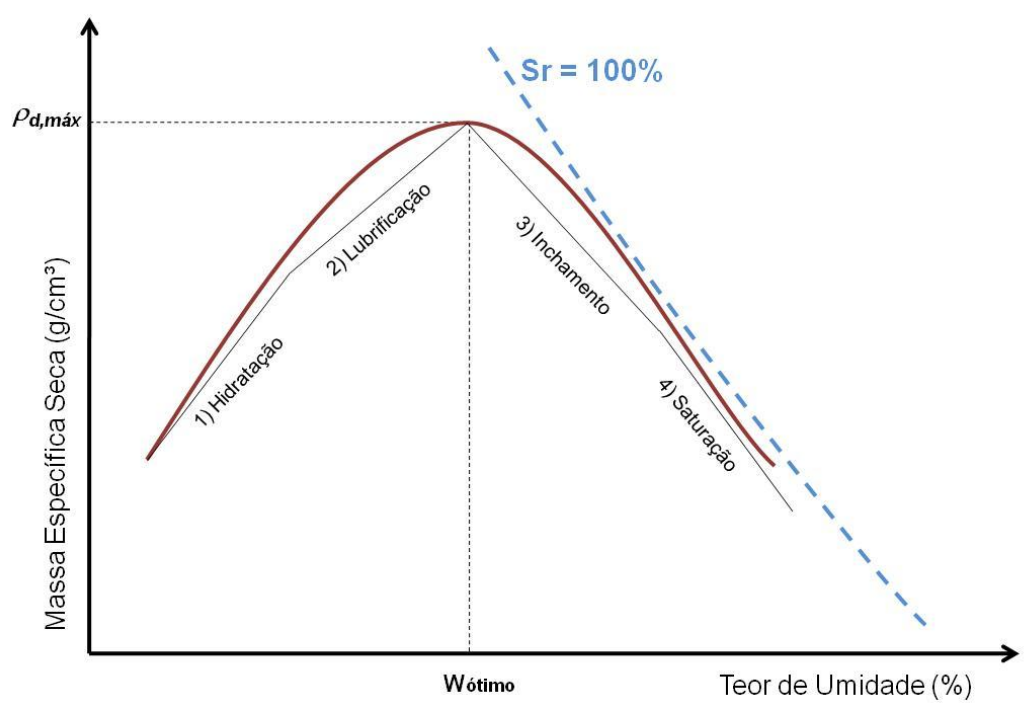

Figura 2.27: Estágios de teor de umidade segundo Hogentogler (1937).

Quando o teor de umidade do solo é baixo (inferior à umidade ótima de compactação), o atrito entre as partículas sólidas é elevado e a redução dos vazios do solo não é de tamanha significância. Já para teores de umidade mais elevados (acima da umidade ótima de compactação), parte da energia do processo de compactação é absorvida e amortecida pela água, ao invés do solo, não sendo tão eficiente o processo. Para o teor de umidade adequado (denominado teor de umidade ótimo), a água funciona como um lubrificante das partículas sólidas, que se acomodam em uma estrutura mais compacta e densa.

Durante o processo de compactação, o teor de umidade permanece praticamente constante (ocorre apenas uma perda de aproximadamente $0,5 \%$ devido à evaporação durante o procedimento). Dessa forma, o aumento da massa específica do solo decorre da expulsão de ar dos vazios antes presente em sua estrutura. Contudo, quando o teor de umidade é elevado, o ar encontra-se envolto por uma película de água e a energia proveniente da compactação não é suficiente para conseguir expulsá-lo. Novamente, portanto, frisa-se a importância da determinação do teor de umidade ótimo e controle do mesmo durante a execução em campo.

É possível estimar a resistência de um solo compactado por meio de diversos ensaios, como, por exemplo, o ensaio de compressão simples, a partir do qual é comprovado que a resistência de um solo é inversamente proporcional ao seu teor de umidade. É importante salientar, contudo, que teor de umidade ótimo não é aquele que confere a maior resistência ao solo. O teor de umidade ótimo é aquele que promove a estrutura mais estável possível ao solo, permanecendo esse menos suscetível a variações de resistência quando submetido à variações do teor de umidade. 
Em outras palavras, um solo que sofreu um processo de compactação atendendo ao teor de umidade ótimo para uma determinada energia, não apresentará a maior resistência possível, mas sim a estrutura mais estável possível independentemente das variações de umidade a serem provocadas pelas mudanças climáticas e pluviométricas. Vargas (1977) ilustra muito bem essa situação ao comparar uma curva de resistência versus o teor de umidade de um solo com a curva de compactação Proctor Normal do mesmo solo, conforme ilustrado na Figura 2.28 a seguir.

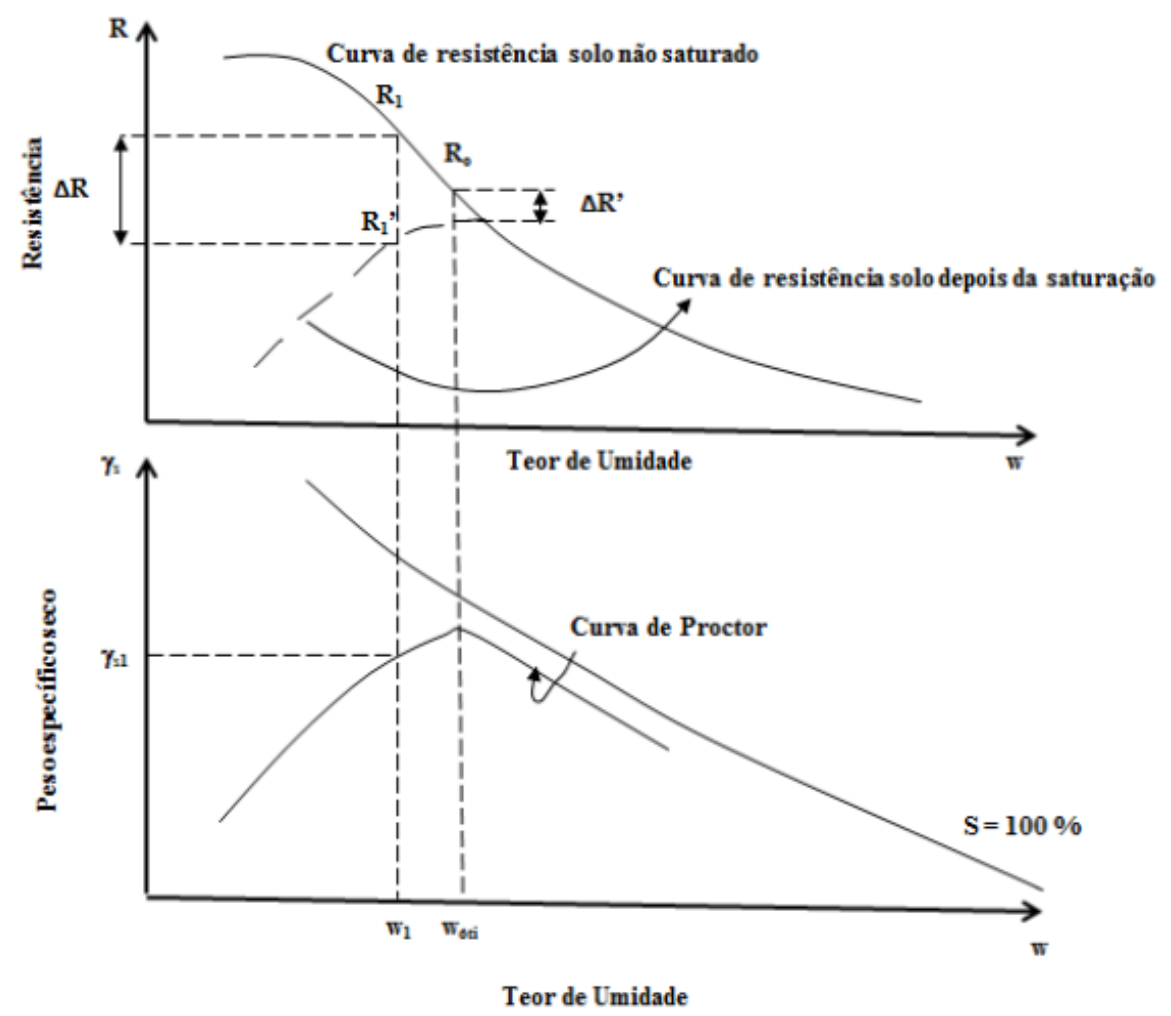

Figura 2.28: Comparação entre a curva de resistência de um solo compactado com a curva de compactação de Proctor. Fonte: Vargas, 1977.

Atrelado ao teor de umidade ótimo está, consequentemente, a massa específica seca máxima que o solo consegue atingir a uma dada energia de compactação recebida. Tais parâmetros referentes à umidade ótima e massa específica seca máxima são justamente os parâmetros visados para obtenção em campo, pois conferem à camada de solo compactada as melhores características possíveis de resistência, permeabilidade, influência da sucção e colapso, e entre outros aspectos. O grau de compactação $(G C)$ é uma relação entre a massa específica seca atingida em campo e a massa específica seca máxima, devendo estar situado em uma faixa pré-determinada em projeto executivo (geralmente de $95 \%$ a $105 \%$ ). 


$$
G C=\frac{\rho_{d, \text { campo }}}{\rho_{\text {d,máximo }}} \cdot 100 \%
$$

Existem diversos métodos e equipamentos utilizados para compactação do solo em campo, cujas energias externas aplicadas podem ser oriundas de ações dinâmicas, estáticas, semi-estáticas ou vibratórias. (VILLAR et al., 2015)

\subsubsection{Influência do Grau de Compactação no Colapso}

Em um estudo sobre compactação para melhoria de solo colapsível, Castro et al. (2017) discorrem sobre ensaios edométricos realizados em um solo com diferentes graus de compactação e teores de umidade. O colapso do solo é tratado como um problema passível de prevenção, sendo a compactação do solo um eficiente método que aumenta a resistência ao cisalhamento e diminui a compressibilidade de um solo.

Os resultados desse estudo ilustraram a influência da sucção no comportamento do solo. Corpos de prova submetidos a sucções mais elevadas apresentaram tensões de préadensamento mais elevadas também, comprovando que, quanto maior a sucção, menor o deslocamento causado pelos carregamentos. Ficou ainda evidente neste estudo que a redução do fenômeno do colapso está associada ao aumento do grau de compactação do solo. Para todos os teores de umidade testados, houve benefício quanto à densificação do solo para redução do colapso. Na Figura 2.29 a seguir fica ilustrado que o potencial de colapso é reduzido conforme o grau de compactação aumenta, permanecendo praticamente inalterado para altos graus de compactação (em torno de 90\%).

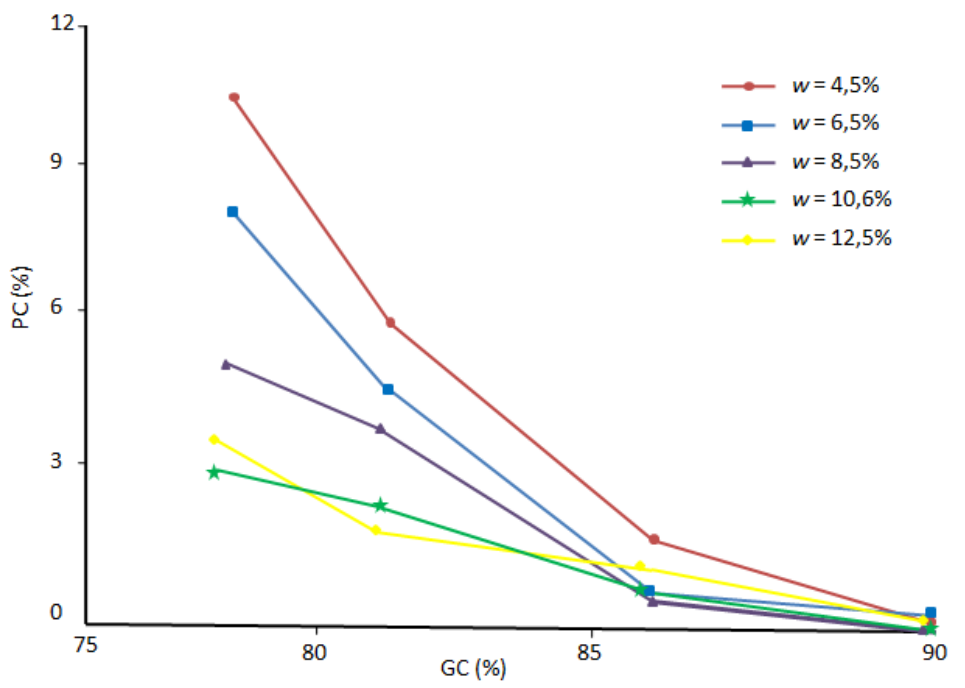

Figura 2.29: Curvas de potencial de colapso versus grau de compactação para as diversas umidades testadas. Adaptado de Castro et al. (2017). 
Verifica-se ainda uma tendência de que, quanto mais deficiente for o processo de compactação do solo, a menores teores de umidade de compactação, maior será magnitude das deformações pelo efeito do colapso. Ou seja, a gravidade do problema está associada aos solos menos densos e inicialmente mais secos. Fica, portanto, evidenciada a importância do controle do processo de compactação conforme especificações de projeto para que os efeitos do colapso possam ser extintos, havendo seguridade da obra e eficiência da melhoria da camada.

Collares (2002) ressalta que Basma \& Tuncer (1992) estudaram diversas amostras de solo compactadas em anel edométrico e observaram que o peso específico seco inicial é o parâmetro que mais impacta o colapso dos solos, sendo o colapso e este parâmetro inversamente proporcionais. Vilar e Gaioto (1994) notaram que em situações onde os aterros são lançados ou compactados de forma inadequada (como bota-foras, aterros construídos a partir de rejeitos de mineração, aterros construídos em regiões áridas e semi-áridas e entre outras situações), formam-se depósitos altamente compressíveis e suscetíveis ao fenômeno de colapso.

Em outras palavras, os solos colapsíveis que sofreram adequadamente o processo de compactação não mais permanecem à mercê do fenômeno de colapso quando o teor de umidade é aumentado, pois a sua estrutura não é mais considerada instável (uma vez que houve a redução de seu elevado índice de vazios e porosidade).

\subsubsection{Compactação como Reforço de Fundações Diretas}

De acordo com Cintra \& Aoki (2009), para redução do recalque de colapso e viabilização da utilização de fundações por sapatas (ou radiers), o método de melhoria de solos colapsíveis mais utilizado tem sido a compactação do solo a uma profundidade equivalente a metade do bulbo de tensões. Como o bulbo de tensões para fundações diretas é adotado como o dobro da dimensão da base da fundação $(2 B)$, a compactação deve se proceder até uma profundidade equivalente à base $B$ do elemento de fundação. Além disso, o aumento da dimensão da cava em $B / 2$, para cada lado, faz com que, até essa profundidade, a propagação de tensões ocorra somente no maciço compactado (espraiamento de tensões na proporção 2:1). 


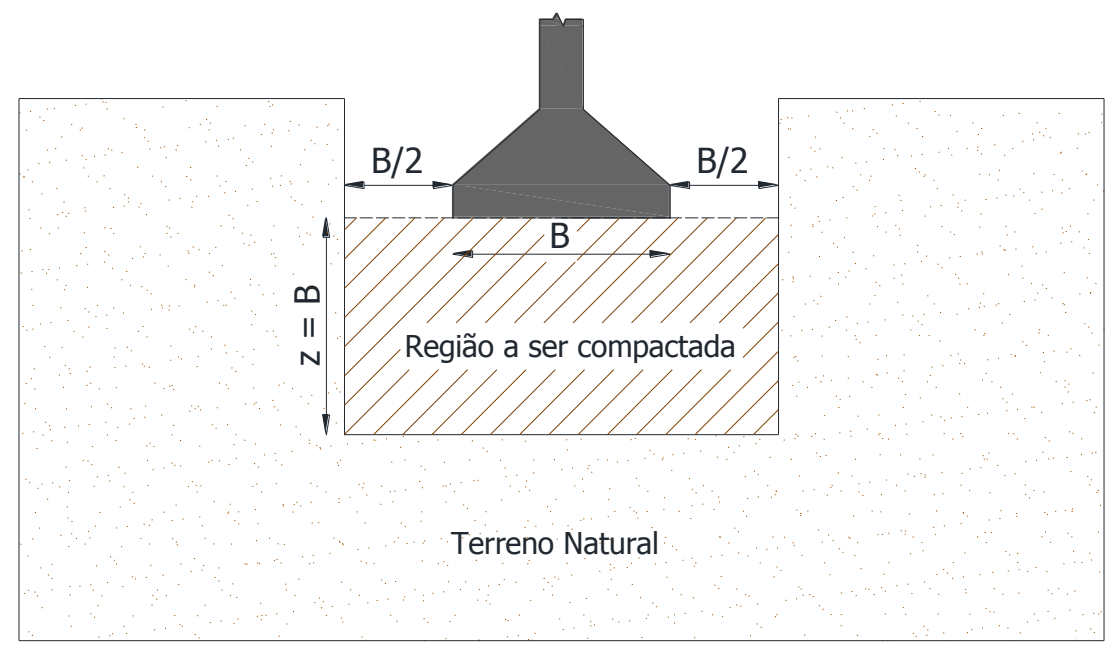

Figura 2.30: Recomendação para compactação de uma camada colapsível para apoio de fundações diretas. Adaptado de Cintra \& Aoki (2009).

Todavia, para fundações diretas de maiores dimensões (solicitadas por maiores carregamentos), esse volume de solo a ser compactado acaba por ficar relativamente grande, tornando, em muitos casos, inviável sua execução (tanto técnica quanto economicamente).
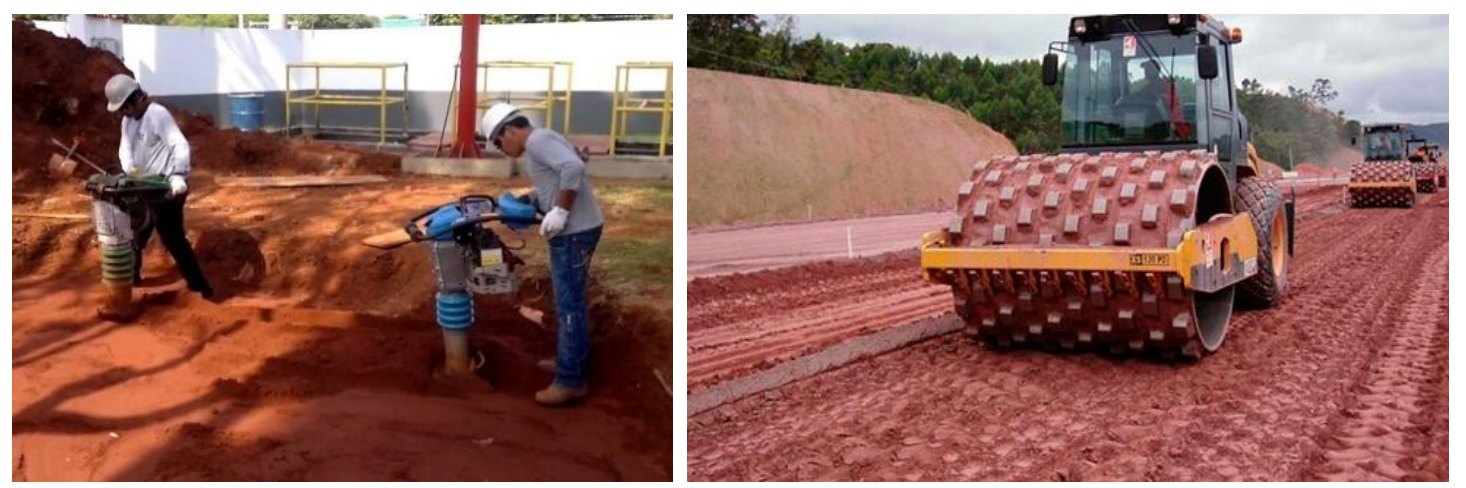

Figura 2.31: Compactação de Solo através de vibrador pneumático (a) e equipamento rolo pé de carneiro (b).

\subsubsection{Reforço por Colunas de Deslocamento}

Em vista de tal problemática, cabe aqui salientar quanto à técnica de compactação através de colunas de deslocamento, que consiste em colunas verticais inseridas e compactadas na camada de solo menos resistente, cuja finalidade é a densificação e melhoria das propriedades do solo na região adjacente à coluna, a qual provoca uma expansão (deslocamento) para as regiões laterais durante sua compactação. Dentre os principais materiais utilizados para comporem as colunas destacam-se a brita, a areia e o solo-cimento, podendo ser empregados puramente ou misturados e que podem ainda serem compactados através do processo de compactação dinâmica, impactos ou de vibrocompactação. 


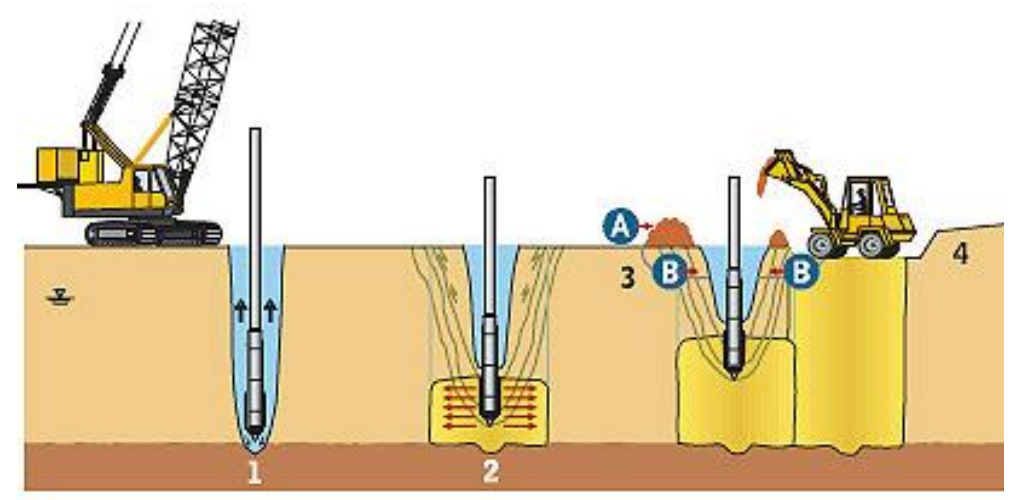

Figura 2.32: Ilustração da Técnica de melhoria de solo com coluna de deslocamento preenchida com solo através da vibrocompactação (QUINALIA, 2009).

A técnica de reforço através do tratamento do solo com colunas de deslocamento já é amplamente difundida e tem sido frequentemente utilizada em meio prático nacional. Consiste basicamente em reduzir os índices de vazios e a permeabilidade do solo em seu entorno (através da compactação) e por consequência melhorar a capacidade resistente do mesmo. Todavia, na literatura, é pouco encontrado a respeito da utilização do próprio solo laterítico compactado como material para preenchimento da coluna e reforço do solo, sendo mais difundidas as técnicas que utilizam misturas solo-brita ou solo-cimento (envoltas ou não por geossintéticos).

De modo a assegurar a eficiência do reforço utilizado, deve-se realizar um controle de compactação, para garantir que os parâmetros de projeto requeridos tenham sido de fato atingidos. Para tanto, são realizados ensaios após a compactação que, além de analisar a eficiência do solo compactado, permitam também a estimativa de parâmetros de deformabilidade do mesmo. Dentre os principais ensaios, destacam-se os citados a seguir.

i. $\quad$ SPT (Standart Penetration Test) e CPT (Cone Penetration Test): ensaios de percussão, amplamente difundidos e empregados, que fornecem parâmetros de resistência de ponta e/ou lateral e que, através de equações empíricas, fornecem o módulo de deformabilidade do solo.

ii. Prova de carga em placa: confere uma curva tensão x recalque, a partir da qual é possível estimar o módulo de deformabilidade.

iii. Controle de recalque e deslocamentos: monitoramento feito por instrumentos de controle de recalque e inclinômetros. 
iv. Retirada de Amostras Indeformadas: determinação do módulo de deformabilidade através de ensaios triaxiais (os quais conferem uma curva tensão $x$ deslocamento) realizados em laboratório com as amostras indeformadas retiradas do campo.

\subsection{Comportamento do solo reforçado com uma malha de colunas}

Para que o aumento da capacidade resistente seja significativo para a camada como um todo, são necessárias várias colunas de reforço, confeccionando uma malha e ocorrendo um efeito de superposição entre elas (quando carregadas), conhecido como "efeito de grupo".

Ensaios acerca do melhoramento de solos arenosos com colunas compactadas de areais realizadas por Gusmão (2005) mostram que, para colunas com diâmetros de 300 milímetros, há uma melhoria em termos de compactação no solo adjacente de cerca de 2 a 2,5 vezes o diâmetro da coluna de reforço. Assim sendo, pode-se admitir o espaçamento da malha de melhoramento como 4 a 5 vezes o diâmetro da coluna.

O comportamento apresentado em geral, bem como os mecanismos de ruptura apresentados por um grupo de estacas é distinto daqueles apresentados por um elemento isolado. Silva (1996) discorre que, quando ocorre a aproximação de elementos de fundação, ocorre também uma interação entre os elementos adjacentes modificando as tensões normais atuantes na face dos mesmos. Além disso, ocorre o efeito de superposição dos bulbos de tensões de cada elemento de fundação, aumentando a solicitação sobre o solo e modificando as possíveis superfícies de ruptura.

Estudos realizados por Kishida e Meyerhof (1965) apontam que, para elementos pouco espaçados, ocorre uma tendência de ruptura como se fosse um único elemento (denominado "tubulão equivalente") e a capacidade de carga do sistema é a capacidade de carga do "tubulão equivalente". Já para elementos com maiores espaçamentos, a capacidade de carga do sistema equivale à soma das capacidades de carga dos elementos.

O entendimento do mecanismo de transmissão do carregamento suportado pela fundação para o solo reforçado com colunas, contudo, é complexo e envolve inúmeras variáveis, tais como rigidezes (tanto do substrato quanto dos elementos de reforço), características do 
local, espaçamento, geometria e diâmetro das colunas, saturação do meio e entre inúmeras outras.

Tendo em vista tal dificuldade, utiliza-se o conceito de "célula unitária", onde o comportamento de toda e qualquer coluna é semelhante, independentemente da sua localização espacial na malha. A célula unitária é composta por uma quantidade de solo circundante (afetada pelo processo de execução da coluna), tal que os esforços radiais em seu perímetro sejam nulos. Somando a área da célula unitária $\left(A_{s}\right)$ com a área da seção transversal da coluna $\left(A_{p}\right)$ tem-se a denominada área de influência $(A)$.

$$
\boldsymbol{A}=\boldsymbol{A}_{\boldsymbol{s}}+\boldsymbol{A}_{\boldsymbol{p}}
$$

São encontradas na literatura distribuições das colunas em malhas triangulares, quadradas e hexagonais (sendo as duas primeiras, geralmente, as mais comuns). As malhas triangulares acabam por formar uma célula unitária de geometria hexagonal; as quadradas formam células unitárias também quadradas e, por fim, as malhas hexagonais acabam por formar células unitárias triangulares. O espaçamento entre os eixos longitudinais das colunas é designado por $s$ e, geralmente, é proporcional ao diâmetro $d$ das colunas.

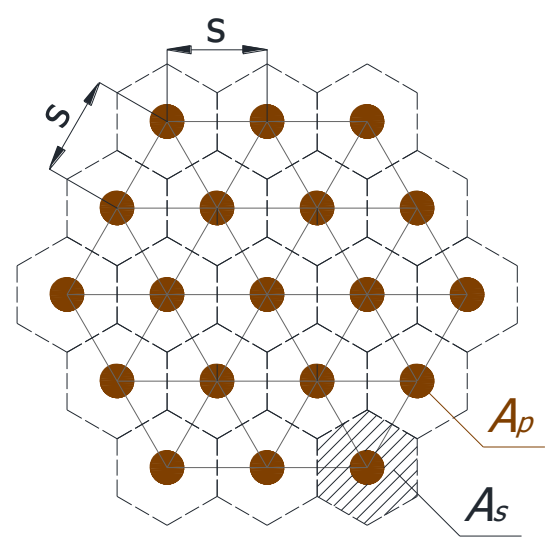

Figura 2.33: Exemplo de malha triangular com célula unitária hexagonal.

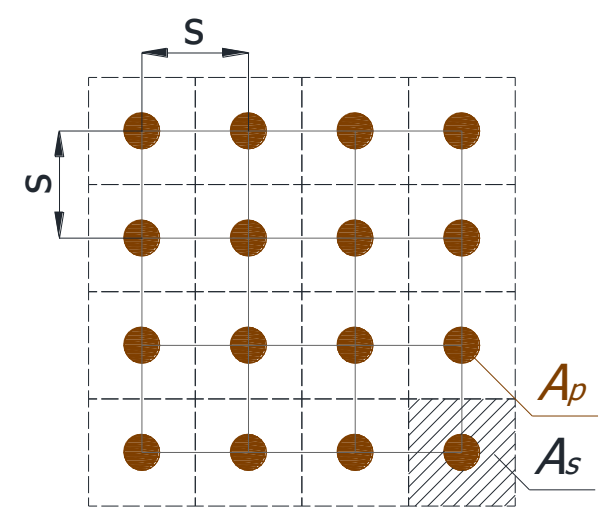

Figura 2.34: Exemplo de malha quadrada com célula unitária quadrada. 


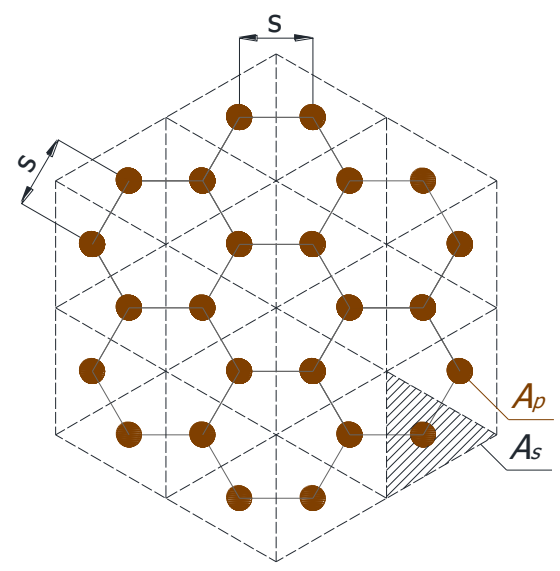

Figura 2.35: Exemplo de malha hexagonal com célula unitária triangular.

A taxa de cobertura ou área de substituição $(\alpha)$ pode ser obtida pela relação entre a área da seção transversal da coluna e a área de influência, geralmente expressa em porcentagem, e dada pela seguinte expressão:

$$
\alpha(\%)=\frac{A_{p}}{A} .100
$$

\subsection{Modelagem Numérica}

Os materiais e ambientes são pertencentes a um modelo contínuo, compostos por infinitos pontos e que possuem infinitos graus de liberdade, uma vez que as variáveis se distribuem continuamente em todo o domínio do problema. Geralmente, não é possível resolver analiticamente tais problemas e recorre-se então aos denominados modelos discretos (ou numéricos), obtidos dos modelos contínuos através de hipóteses simplificadoras e de sua discretização (transformação em um modelo discreto, com finitos pontos).

Métodos numéricos permitem a obtenção de tensões e deslocamentos em qualquer ponto do volume da obra geotécnica analisada. Uma grande vantagem dos modelos numéricos consiste em possibilitar a resolução de problemas teóricos analiticamente insolúveis pela sua substituição por uma solução numérica aproximada. 


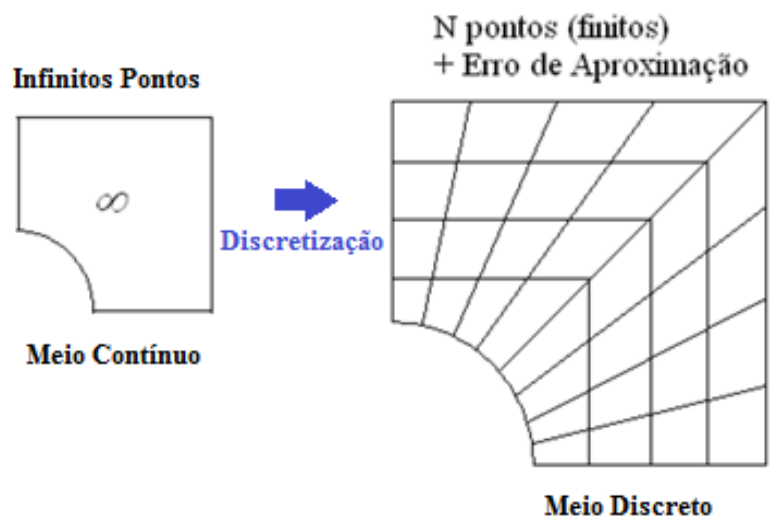

Figura 2.36: Discretização de um meio contínuo. Adaptado de Alves (2007).

De acordo com Alves (2007), quando um modelo contínuo é substituído por um modelo discreto, a solução de um sistema de equações diferenciais é substituída pela solução de um sistema de equações algébricas, cuja resolução torna-se relativamente mais fácil. Existem diversos métodos para realização de modelagens numéricas, tais como o Método das Diferenças Finitas (MDF), Método dos Elementos de Contorno (MEC) e, o mais amplamente difundido em geotecnia, o Método dos Elementos Finitos (MEF).

\subsubsection{Método dos Elementos Finitos}

O método dos elementos finitos (MEF) é um procedimento numérico, amplamente empregado nas esferas da engenharia como um todo, utilizado para resolver problemas da mecânica do contínuo associando tensões com deformações. Esse método consiste na subdivisão do meio contínuo em um número conhecido (finito) de elementos, interconectados por pontos discretos denominados nós.

Tal subdivisão gera uma malha (na qual os vértices são os pontos nodais ou nós) cuja geometria e densidade são de fundamental importância para uma boa convergência do resultado, sendo tão mais densa quanto mais precisão os resultados requeiram. Contudo, quanto mais densa for a malha, mais elementos existirão e mais lentamente o modelo será processado, sendo necessária, assim, uma otimização entre a precisão de resultados e o processamento do modelo. Em função dos nós, pode-se calcular o deslocamento no interior de um elemento através de uma interpolação linear.

Além de uma escolha adequada da malha de elementos finitos, são de suma importância a constituição de uma geometria tal como encontrada em modelo real e o 
fornecimento dos parâmetros adequados ao modelo. Em modelos numéricos de dados experimentais já realizados, por exemplo, não é relevante apenas o bom ajuste do resultado do modelo com o experimental sem que haja fidedignidade entre os parâmetros e geometrias do modelo com os apresentados em campo.

A modelagem numérica pode ser feita em uma, duas ou três dimensões $(1 D, 2 D$ ou $3 D$ ), sendo tão mais complexa quanto mais dimensões analisadas. A malha gerada pode ter elementos triangulares ou quadrados, podendo ainda serem lineares (mais simples) ou quadráticos (mais complexos e que resultam em uma modelagem mais fina).

Elemento linear

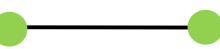

\section{Elemento quadrático}

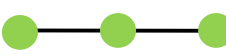

Figura 2.37: Elementos para modelagem em uma dimensão $(1 D)$.

Elemento linear

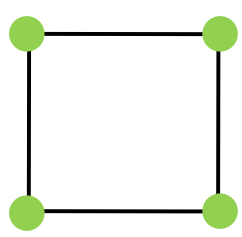

Malha quadrada

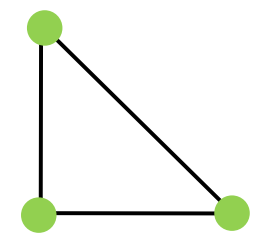

Malha triangular

Elemento quadrático

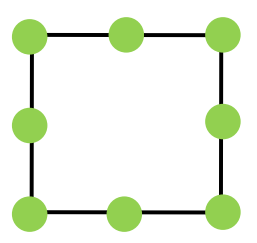

Malha quadrada

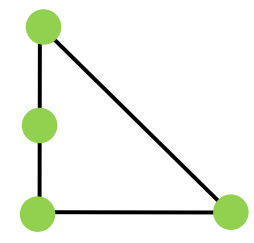

Malha triangular

Figura 2.38: Elementos para modelagem em duas dimensões (2D).

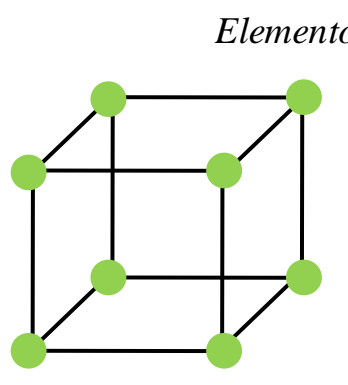

Malha quadrada

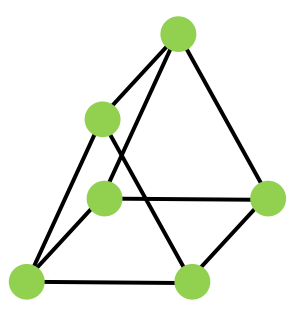

Malha triangular

Elemento quadrático

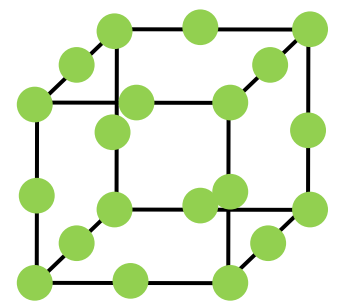

Malha quadrada

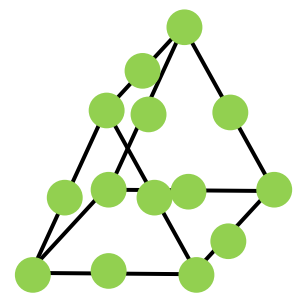

Malha triangular

Figura 2.39: elementos para modelagem em três dimensões (3D).

Por fim, outros aspectos decisivos na conduta da modelagem são a imposição das condições de contorno adequadas e a escolha do modelo constitutivo (ou reológico) a ser 
adotado para o modelo, o qual infere diretamente nos parâmetros a serem fornecidos e no comportamento dos materiais estudados na modelagem realizada.

\subsubsection{Modelos Constitutivos}

Modelos constitutivos (ou reológicos ou ainda comportamentais) são modelos que descrevem o comportamento do solo através de um modelo matemático. Eles permitem correlacionar as tensões (ou carregamentos) aplicados ao sólido (volume) estudado com as deformações sofridas pelo mesmo. Existem diversos modelos constitutivos, para diversas esferas de conhecimento, sendo cada um mais adequado a depender do caso e material estudados.

De acordo com Lodi (1998), de maneira elementar na resolução de problemas geotécnicos, são comumente adotados pelo menos dois modelos de comportamento para os solos. Utiliza-se a teoria da elasticidade para a previsão de recalques imediatos de uma determinada fundação (modelo elástico-linear), enquanto que, para situações relacionadas ao problema de ruptura, são considerados apenas os parâmetros de resistência como coesão e ângulo de atrito (modelo rígido-plástico). De maneira geral, pode-se afirmar que o estudo das tensões e deformações dá-se sob a visão dos conceitos de um material elástico-linear, ao passo que o estudo de estabilidade e ruptura é feito considerando um comportamento rígido-plástico.

Os modelos são tão mais complexos quanto mais parâmetros requisitarem. É melhor, em muitos casos, a escolha de um modelo de comportamento mais simples baseado em parâmetros mensuráveis e confiáveis do que a escolha de um modelo mais elaborado baseado em parâmetros complexos obtidos por correlações empíricas devido à falta de dados.

\subsubsection{Modelo de Mohr-Coulomb}

Trata-se de um modelo elástico linear perfeitamente plástico com um critério de ruptura do tipo Mohr-Coulomb. É frequentemente utilizado para representar a ruptura por cisalhamento de um solo ou de uma rocha branda. É um comportamento elasto-plástico simples adaptado ao caso de materiais granulares submetidos a carregamentos constantes. 
Esse modelo, contudo, apresenta algumas limitações, tais como apresentar um mesmo módulo de carregamento e descarregamento e ser uma representação muito simplista do comportamento real do solo.

\subsubsection{Modelo Hardening-Soil}

Parecido com o de Mohr-Coulomb, mas permite uma não linearidade. É um modelo hiperbólico elasto-plástico com endurecimento. Seu critério de ruptura também é do tipo MohrCoulomb. Os módulos de carregamento e descarregamento são distintos.

\subsubsection{Modelo Soft-Soil}

Modelo que permite levar em consideração a coesão apresentada pelo solo. Mais indicado para turfas e solos moles em geral.

\subsubsection{Modelo Cam-Clay}

O modelo cam-clay foi desenvolvido para representação do comportamento de solos argilosos levemente pré-adensados, que tendem a sofrer redução de volume durante o processo de plastificação. Tal situação faz com que haja uma limitação do modelo para reprodução do comportamento de solos altamente pré-adensados. (LODI, 1998)

Trata-se de um modelo que permite analisar conjuntamente os comportamentos da resistência apresentada e a deformabilidade sofrida pelo solo. Ambos os comportamentos são de fundamental importância para governar o equilíbrio do solo, mas são, em muitos casos, tratados de maneira isolada. A grande vantagem do modelo é, portanto, assimilar ambos os comportamentos, que governam conjuntamente o solo. É um modelo que permite também representar o ensaio edométrico.

Existem, ainda, outros modelos, inclusive para as rochas em específico, tais como o Modelo de Hoek-Brown e o Modelo Jointed-Rock (que permite caracterizar de maneira anisotrópica as rochas). 


\subsection{Modelagem Física}

Uma eficaz reprodução do que ocorre em campo através de um modelo em escalas reduzidas é conferida com a utilização de um equipamento denominado centrífuga geotécnica. A partir da década de 1980, a utilização da centrífuga para tratamento de problemas envolvendo mecânica dos solos passou a ser frequente, ganhando cada vez mais espaço em meio geotécnico. (CINTRA, LEVACHER \& GARNIER, 1990)

Juntamente com a modelagem numérica, a modelagem física torna-se uma importante ferramenta para análise e predição do comportamento de um conjunto de elementos geotécnicos. Ambas modelagens apresentam suas vantagens e desvantagens, mas devem, sempre que possível, serem utilizadas como ferramentas complementares de análise, e não excludentes.

A essência da modelagem física consiste basicamente em reproduzir o que ocorre em campo, em um modelo geotécnico de escala $1 / n$, através de uma aceleração equivalente a $n$ vezes a aceleração da gravidade (n.g). Dessa forma, um modelo em escala real (protótipo) que provavelmente seria inviável de confeccionar (seja por razões econômicas ou executivas), tornase facilmente atingível graças à reprodução em um modelo de escala reduzida na centrífuga. Essa relação, que expressa as dimensões do protótipo como sendo $n$ vezes as dimensões do modelo, é tida como a lei básica da modelagem centrífuga.

$$
\boldsymbol{h}_{\boldsymbol{p}}=\boldsymbol{n} \cdot \boldsymbol{h}_{\boldsymbol{m}}
$$

Caso houvesse apenas a reprodução em modelo reduzido, sem a utilização da centrífuga, não haveria a reprodução do estado de tensões encontrado em campo, devido ao peso próprio e carregamentos serem diferentes do protótipo para o modelo. Por isso a necessidade de impor uma aceleração (equivalente a $n$ vezes a da gravidade) que compense essa redução de dimensões (também equivalente a $n$ vezes) de modo a reproduzir o estado de tensões in situ.

As relações de escala entre os modelos e os protótipos já foram amplamente estudadas e são ilustradas na Tabela 2.5 abaixo, que sumariza as principais relações utilizadas em ensaios com centrífuga geotécnica. É ilustrado também, na Figura 2.40, as relações entre o protótipo e o modelo de acordo com tais escalas. 
Tabela 2.5: Relações de escala entre protótipos e modelos. Fonte: Cintra, Levacher \& Garnier (1990).

\begin{tabular}{|c|c|c|c|}
\hline Grandeza & Protótipo & $\begin{array}{c}\text { Modelos } \\
\text { Centrifugados }\end{array}$ & $\begin{array}{c}\text { Modelos não } \\
\text { Centrifugados }\end{array}$ \\
\hline Aceleração & 1 & $\mathrm{n}$ & $\mathrm{n}$ \\
\hline Área & 1 & $1 / \mathrm{n}^{2}$ & $1 / \mathrm{n}^{2}$ \\
\hline Deformação Específica & 1 & 1 & 1 \\
\hline Deslocamento & 1 & $1 / \mathrm{n}$ & $1 / \mathrm{n}$ \\
\hline Força & 1 & $1 / \mathrm{n}^{2}$ & $1 / \mathrm{n}^{3}$ \\
\hline Massa & 1 & $1 / \mathrm{n}^{3}$ & $1 / \mathrm{n}^{3}$ \\
\hline Massa Específica & 1 & 1 & 1 \\
\hline Módulo de Young & 1 & 1 & $1 / \mathrm{n}$ \\
\hline Momento de Inércia & 1 & $1 / \mathrm{n}^{4}$ & $1 / \mathrm{n}^{4}$ \\
\hline Peso Específico & 1 & $\mathrm{n}$ & 1 \\
\hline Tensão & 1 & 1 & $1 / \mathrm{n}$ \\
\hline Volume & 1 & $1 / \mathrm{n}^{3}$ & $1 / \mathrm{n}^{3}$ \\
\hline
\end{tabular}

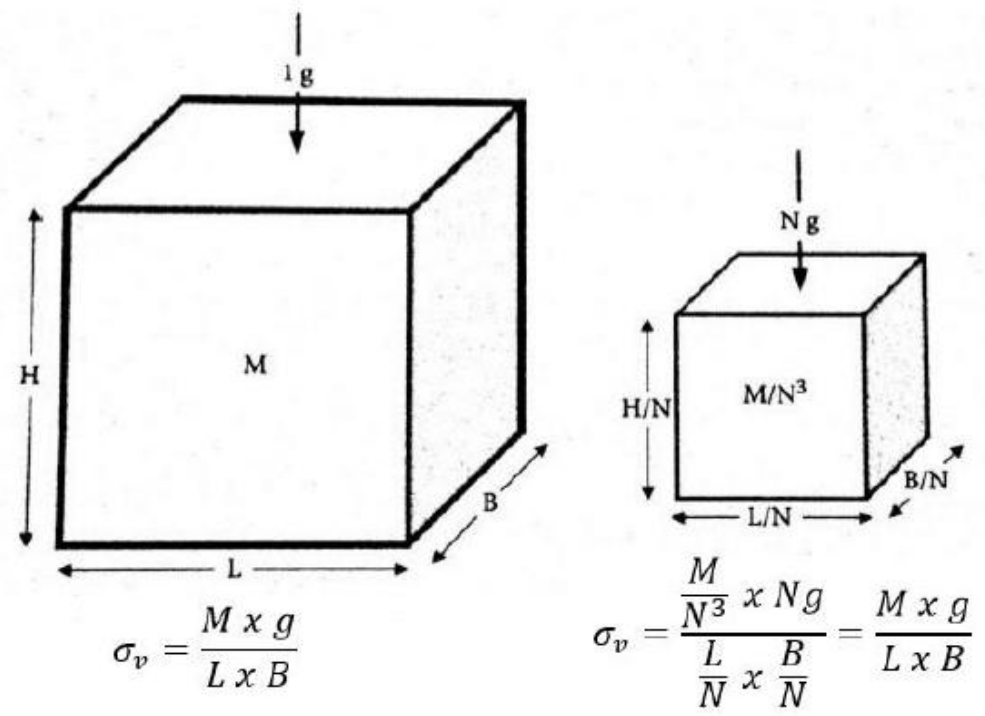

Figura 2.40: Princípio fundamental da modelagem em centrífuga. Fonte: Machado, 2016.

De acordo com Vianna (2005), todos os modelos testados em condições de $1 g$ são, por definição, protótipos. A maneira ideal de análise de um modelo é a sua comparação com o protótipo. Porém, quando isso não é possível, recorre-se a uma técnica muito utilizada em centrífugas denominada "modelagem de modelos", que correlaciona um modelo com outro equivalente ao invés de relacionar o modelo diretamente com o protótipo. 


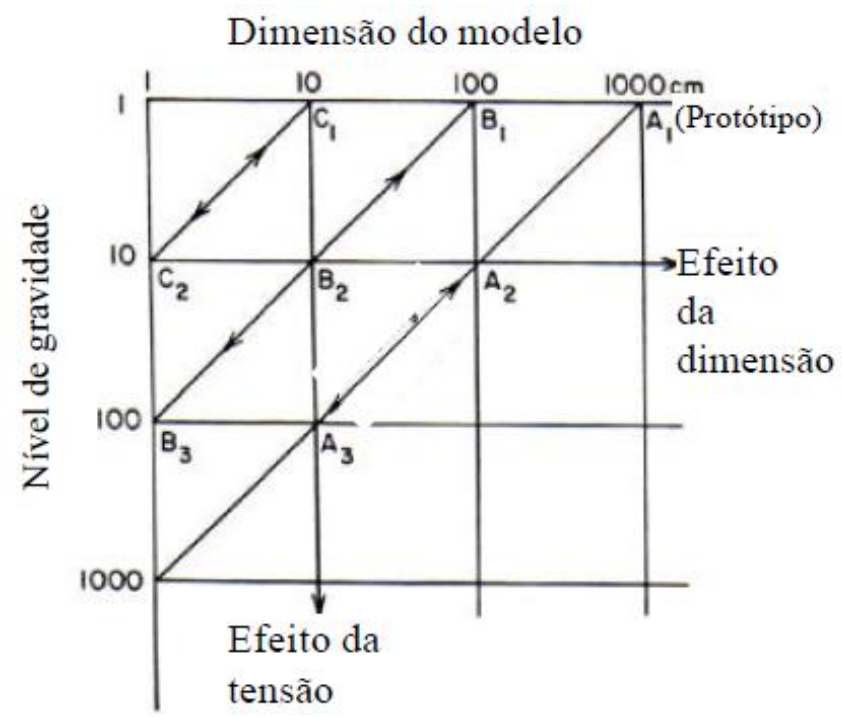

Figura 2.41: Representação da Modelagem de modelos. Fonte: Vianna, 2005.

Nessa técnica, por exemplo, um protótipo de $100 \mathrm{~cm}$ indicado por $B_{1}$ pode ser representado por um modelo de $10 \mathrm{~cm}\left(B_{2}\right)$ a uma aceleração de $10 \mathrm{~g}$ ou então por um modelo de $1 \mathrm{~cm}\left(B_{3}\right)$ a uma aceleração de $100 g . B_{2}$ e $B_{3}$ não são apenas modelos representativos do protótipo $B_{1}$, mas são, também, modelos um do outro, passíveis de correlações (por isso o nome modelagem de modelos).

O termo "atuação" em modelagem centrífuga corresponde a uma aplicação externa de quaisquer tensões, carregamentos ou perturbações que não oriundos do peso próprio do material.

Deve-se atentar, ainda, à limitação do fator de escala das partículas de solo utilizado, pois as dimensões dos elementos são reduzidas por uma escala $n$, mas os diâmetros das partículas permanecem inalterados, não obedecendo à proporção ou escala utilizada. Estudos apontam que, a partir da relação onde a dimensão do modelo equivale a pelo menos 15 vezes a dimensão da partícula, não ocorrem grandes influências nos resultados devido ao efeito do tamanho das partículas utilizadas. Estudos mais conservadores já alertam que tal relação deve ser no mínimo igual a 50 vezes. (LOPES, 2015)

Fuglsang \& Ovesen (1988) realizaram alguns ensaios experimentais dos quais deduziram que a capacidade de carga de um modelo reduzido não é afetada pelo fator de escala se a relação entre as dimensões do modelo e dos grãos for superior a 30 vezes. 
Outro limitante para a confecção do modelo em escala reduzida é o efeito de borda. Apesar de pouco comentado na literatura, esse efeito deve ser levado em consideração para que os resultados da modelagem não sejam afetados. A caixa de teste, por ser composta de material diferente ao do solo ensaiado, pode acabar por conferir uma resistência a mais medida, que não a do solo propriamente. Para que isso seja evitado, os elementos a serem ensaiados devem ficar distanciados a uma determinada distância mínima da borda para que não haja interferência do atrito oferecido pela caixa em seu entorno (denominada efeito de borda).

Dentre os diversos modelos já desenvolvidos de centrífugas geotécnicas, os mais comumente encontrados são os de centrífuga de viga (ou de braço) e os de tambor. De acordo com Lopes (2015), a centrífuga de viga é o modelo mais utilizado e consiste basicamente de um eixo central acoplado a um braço (simétrico ou não) no qual une-se, em sua extremidade, uma caixa (ou container) onde é montado e ensaiado o modelo. Já nas centrífugas de tambor, o solo é depositado em um cilindro que é rotacionado em relação ao seu eixo central longitudinal, sendo geralmente de menores dimensões quando comparadas às centrífugas de viga.

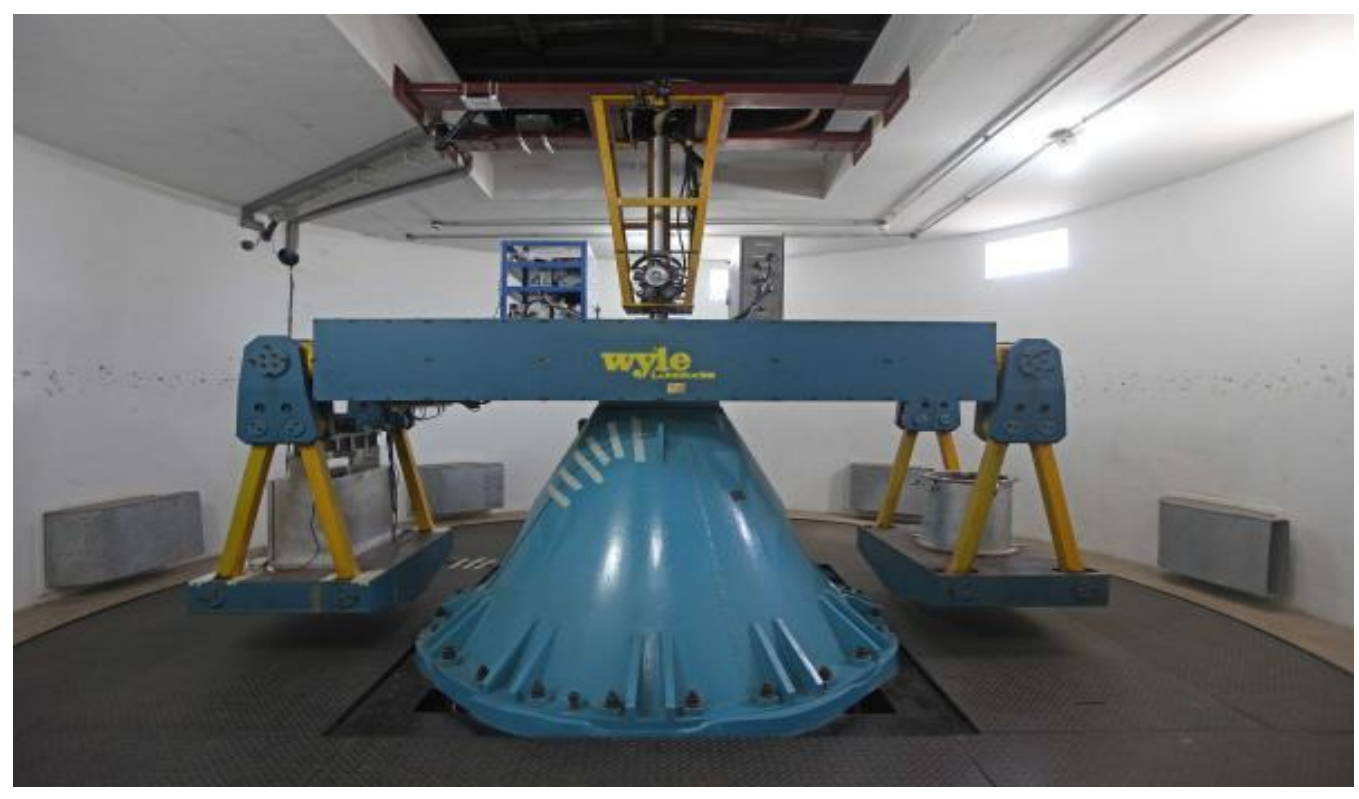

Figura 2.42: Centrífuga de Viga da Universidade Estadual do Norte Fluminense, utilizada para execução da modelagem física do presente estudo. 

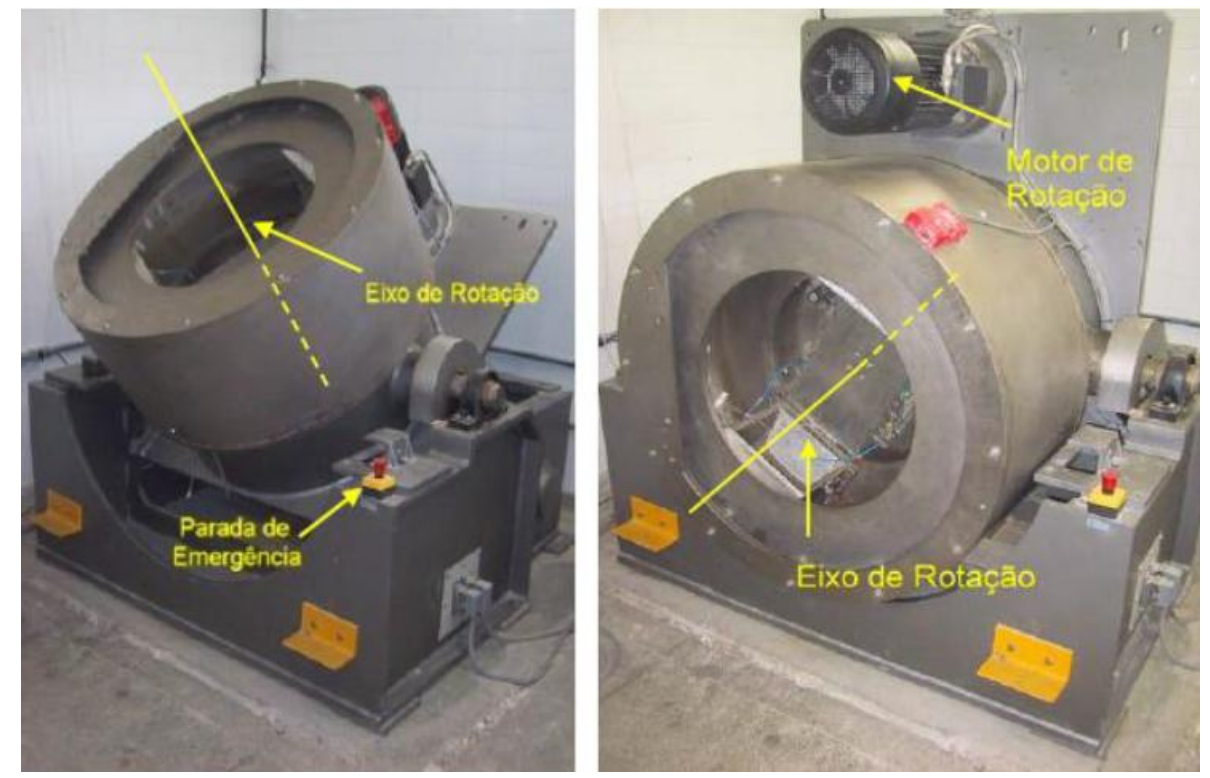

Figura 2.43: Centrífuga de tambor da COPPE - UFRJ em suas posições distintas (basculamento e vertical). Fonte: Machado, 2016.

Cabe novamente salientar que as modelagens físicas e numéricas atuam de maneira complementar. Obviamente, ambas apresentam suas vantagens e desvantagens, sendo melhores ou mais indicadas dependendo do caso e de sua finalidade. Contudo, essas duas ferramentas não são, de maneira alguma, excludentes; e devem, sempre que possível, serem somadas de modo a enriquecerem a análise e predição do comportamento do protótipo. 


\subsection{Características Geológicas}

De acordo com Giachetti, Peixoto e Mondelli (2004), a região de São Carlos está assentada sobre as rochas do Grupo São Bento (constituídas pelos arenitos das Formações Botucatu e Pirambóia) e pelos derrames de rochas efusivas basálticas da Formação Serra Geral. Acima dessas rochas encontram-se os arenitos e conglomerados do Grupo Bauru, recobertos pelos sedimentos cenozóicos.

Tratando-se da região de estudo em específico (campo experimental de fundações da Escola de Engenharia de São Carlos - USP), tem-se um perfil estratigráfico dividido basicamente em uma camada mais superficial de um Sedimento Cenozóico, separada por uma linha de seixos (a aproximadamente 6 metros da superfície), a partir do qual encontra-se a segunda camada, de solo residual do arenito do Grupo Bauru. (GIACHETTI, PEIXOTO \& MONDELLI, 2004).

\subsection{Características Geotécnicas}

\subsubsection{Ensaios de Laboratório}

Por ser objeto de diversas pesquisas e estudos já realizados, são encontrados diversos parâmetros geotécnicos a respeito do solo do campo experimental da Escola de Engenharia de São Carlos.

Em um estudo desenvolvido por Machado (1998) foram realizados diversos ensaios de caracterização do solo do campo experimental, a diferentes profundidades, em um poço com aproximadamente 1,20 metro de diâmetro e 10 metros de profundidade. Primeiramente, metro a metro, foram colhidas amostras indeformadas para determinação dos índices físicos referentes a teor de umidade $(w)$, peso específico seco $\left(\gamma_{d}\right)$, peso específico $(\gamma)$ e índice de vazios $(e)$. Os resultados encontram-se na Tabela 3.1 abaixo. 
Tabela 3.1: Determinação dos índices físicos ao longo de diferentes profundidades. Fonte: Machado, 1998.

\begin{tabular}{|c|c|c|c|c|c|c|c|c|c|}
\hline Profundidade & $\mathbf{1 , 0} \mathbf{~ m}$ & $\mathbf{2 , 0} \mathbf{~ m}$ & $\mathbf{3 , 0} \mathbf{~ m}$ & $\mathbf{4 , 0} \mathbf{~ m}$ & $\mathbf{5 , 0} \mathbf{~ m}$ & $\mathbf{6 , 0} \mathbf{~ m}$ & $\mathbf{7 , 0} \mathbf{~ m}$ & $\mathbf{8 , 0} \mathbf{~ m}$ & $\mathbf{9 , 0} \mathbf{~ m}$ \\
\hline$w(\%)$ & 13,7 & 14,6 & 15,8 & 16,8 & 16,4 & 17,2 & 19,1 & 16,7 & 18,3 \\
\hline$\gamma_{d}\left(\mathrm{kN} / \mathrm{m}^{3}\right)$ & 12,5 & 13,6 & 13,8 & 14,3 & 14,4 & 14,7 & 15,2 & 16,1 & 16,6 \\
\hline$\gamma\left(\mathrm{kN} / \mathrm{m}^{3}\right)$ & 14,2 & 15,6 & 16,0 & 16,7 & 14,8 & 17,1 & 18,1 & 18,8 & 19,6 \\
\hline$e$ & 1,17 & 0,99 & 0,96 & 0,90 & 0,88 & 0,84 & 0,78 & 0,68 & 0,63 \\
\hline
\end{tabular}

Além disso, para algumas profundidades, foram realizados ensaios de compactação com energia Proctor Normal, ensaios de limite de liquidez (LL) e limite de plasticidade (LP), ensaios para determinação da massa específica dos sólidos, e ensaios de granulometria conjunta. Os resultados obtidos encontram-se nas Tabelas 3.2 e 3.3 abaixo.

Tabela 3.2: Resultados dos ensaios de compactação e de caracterização. Fonte: Machado, 1998.

\begin{tabular}{|c|c|c|c|c|c|}
\hline Prof.(m) & $\gamma_{d, \text { máx }}\left(\mathbf{k N} / \mathbf{m}^{\mathbf{3}}\right)$ & $\boldsymbol{w}_{\boldsymbol{o t}}(\boldsymbol{\%})$ & $\mathbf{L L}(\boldsymbol{\%})$ & $\mathbf{L P}(\boldsymbol{\%})$ & $\gamma_{\boldsymbol{s}}\left(\mathbf{k N} / \mathbf{m}^{\mathbf{3}}\right)$ \\
\hline 3,0 & 18,7 & 14,0 & 27,9 & 16,0 & 27,1 \\
\hline 5,0 & 18,4 & 14,8 & 30,9 & 19,8 & 27,5 \\
\hline 8,0 & 18,9 & 11,2 & 28,4 & 17,2 & 27,1 \\
\hline
\end{tabular}

Tabela 3.3: Frações Granulométricas do solo. Fonte: Machado, 1998.

\begin{tabular}{|c|c|c|c|}
\hline Prof. (m) & Areia (\%) & Silte (\%) & Argila (\%) \\
\hline 3,0 & 60,8 & 11,9 & 27,3 \\
\hline 5,0 & 66,7 & 5,90 & 27,4 \\
\hline 8,0 & 68,9 & 13,7 & 17,4 \\
\hline
\end{tabular}

Houve ainda, nesse trabalho, a determinação da curva de retenção de água no solo para a profundidade de 2,0 metros, utilizando os métodos do Funil de Haines para determinação de valores de sucção mais baixos (devido à maior precisão dessa técnica) e da Câmara de Richards para determinação dos valores de sucção mais elevados. Os dados experimentais foram ajustados pelo métodos dos mínimos quadrados pela equação proposta por Fredlund e Xing (1994). 


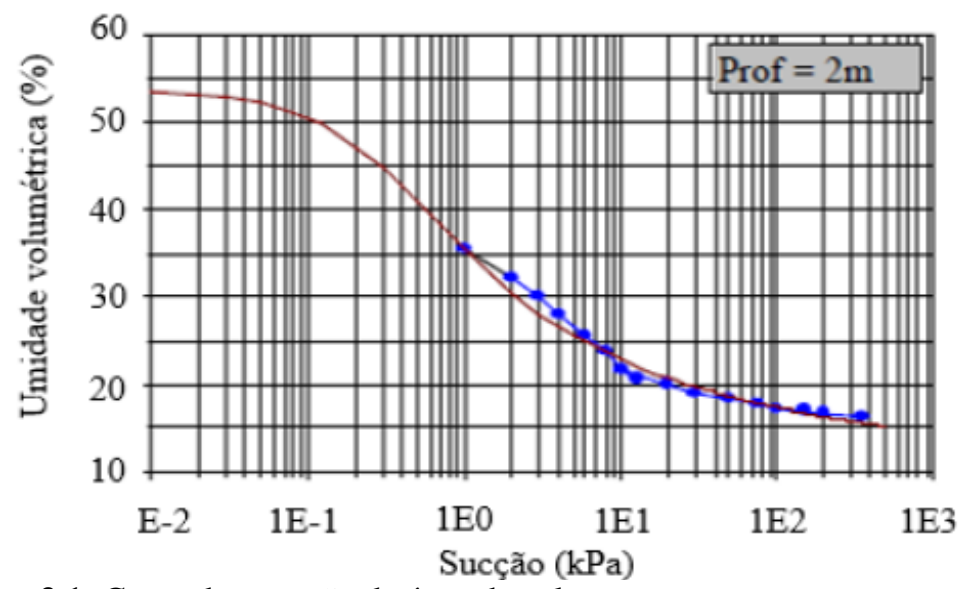

Figura 3.1: Curva de retenção de água do solo pertencente ao campo experimental.

Fonte: Machado, 1998.

De acordo com Freitas (2016), que realizou o ensaio de classificação MCT, o solo do campo experimental corresponde a um solo laterítico argiloso $\left(L G^{\prime}\right)$, conforme ilustrado na Figura 3.2 a seguir.

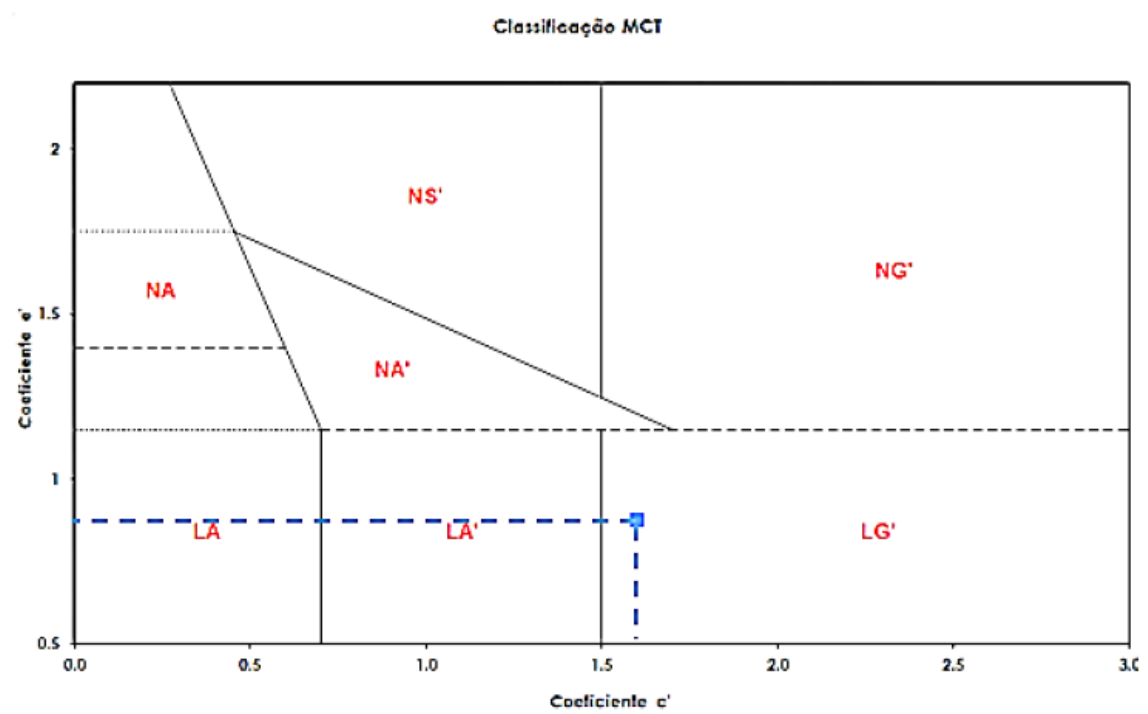

Figura 3.2: Ábaco de classificação MCT para amostra do campo experimental de fundações da EESC, de acordo com Freitas (2016).

\subsubsection{Ensaios de Campo}

Dentre diversos ensaios in situ realizados no campo experimental, são ilustrados a seguir alguns de cunho mais relevante para caracterização do solo de acordo com o presente estudo. 
De acordo com Menegotto (2004), o perfil estratigráfico pode ser divido em três camadas de solo até que seja atingido o impenetrável. A primeira camada refere-se a uma areia fina argilosa marrom e fofa, com aproximadamente 6,40 metros de profundidade. Logo abaixo dessa camada é encontrada uma linha de seixos cuja espessura varia entre 0,10 e 0,50 metro. A segunda camada é composta por uma areia fina argilosa marrom avermelhada, pouco a medianamente compacta, a qual atinge uma profundidade de aproximadamente 24,00 metros. Por fim, a terceira camada é referente a um silte argiloso, compacto a muito compacto.

A posição do nível do lençol freático varia, a depender da época do ano, estando a uma profundidade média de 10 metros. Na Figura 3.3 a seguir são representados valores de sondagens SPT e CPTu realizadas no campo experimental.

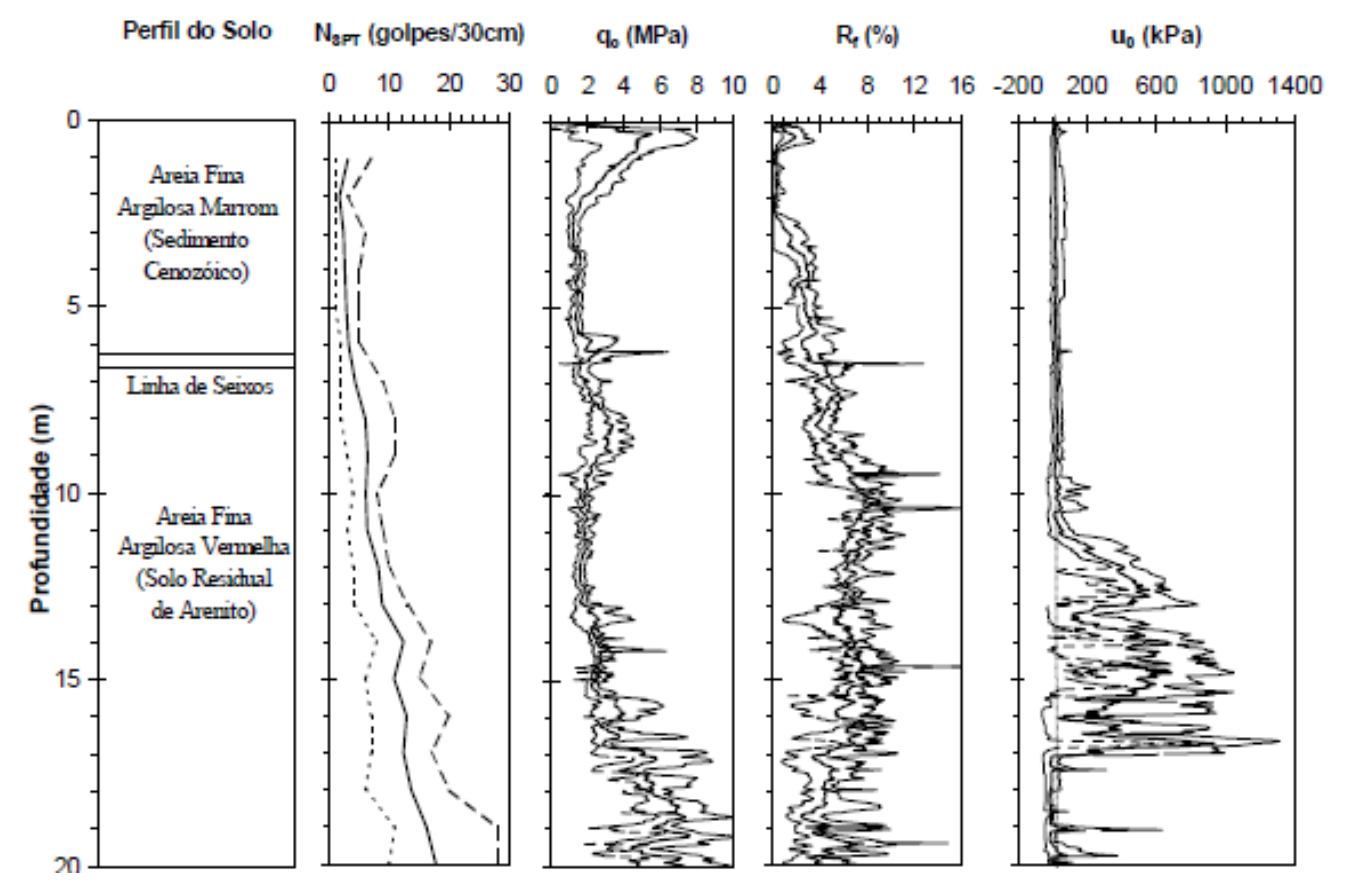

Figura 3.3: Resultados de ensaios de perfilagem SPT e CPTu realizados no campo experimental. Fonte: Menegotto, 2004.

Estudos realizados por Freitas (2016), utilizando reforço do solo com colunas de solo laterítico compactado resultaram em melhorias do solo tanto na região da coluna quanto em seu entorno, com diminuição do índice de vazios e aumento da capacidade resistente do solo adjacente. Após a execução das colunas por apiloamento e compactação das mesmas utilizando o próprio solo laterítico como material de preenchimento, foram retiradas amostras indeformadas em anéis de PVC na região da coluna e em seu entorno e ensaiadas em laboratório para análise dos índices físicos. 


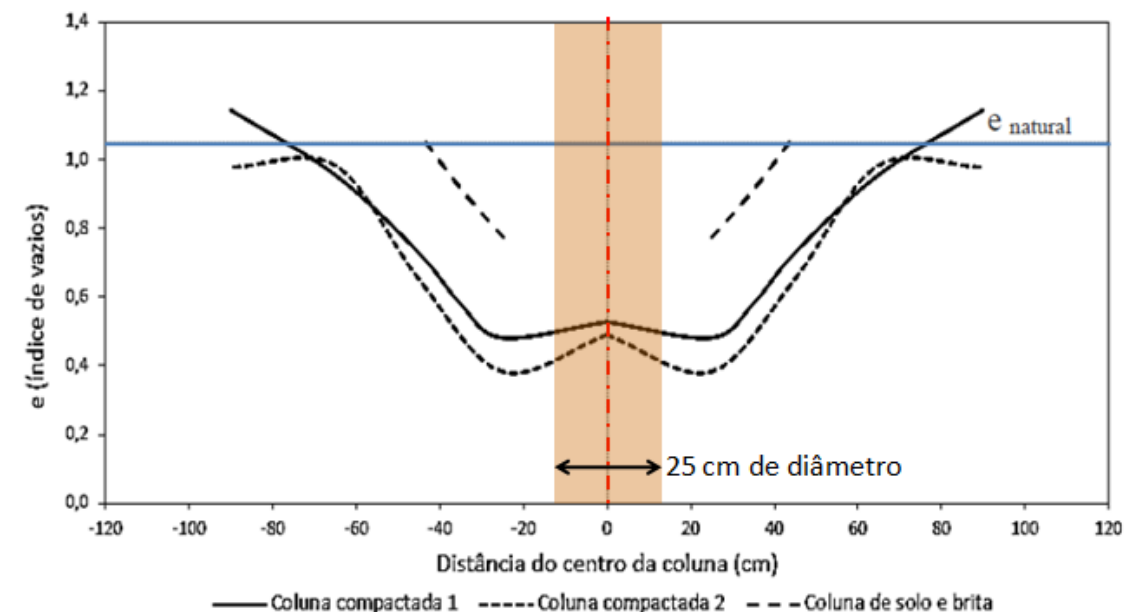

Figura 3.4: Resultados da variação do índice de vazios na região das colunas. Adaptado de Freitas (2016).

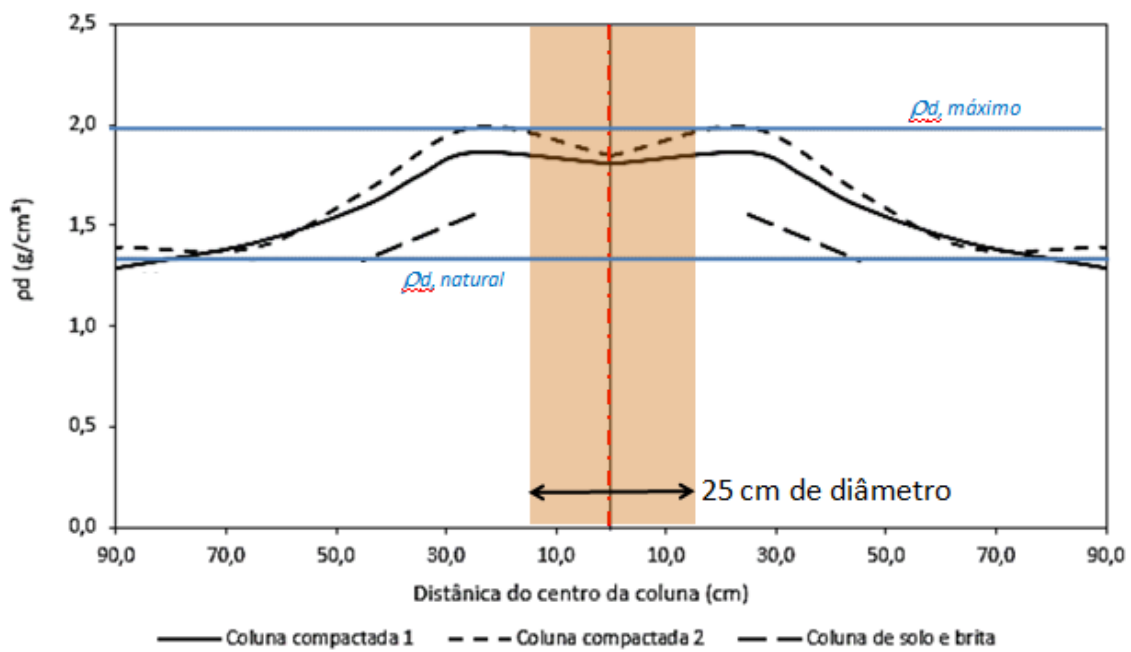

Figura 3.5: Resultados da variação da massa específica seca na região das colunas. Adaptado de Freitas (2016).

Tabela 3.4: Índices físicos obtidos pela retirada de amostras indeformadas a diversas distâncias do centro Coluna 1 (coluna de solo laterítico compactado na situação inundada). Adaptado de Freitas (2016).

\begin{tabular}{|cccc|}
\hline Distância $(\mathrm{cm})$ & $e$ & $\rho d\left(\mathrm{~g} / \mathrm{cm}^{3}\right)$ & $w(\%)$ \\
\hline $\mathbf{0}$ & 0,49 & 1,85 & 14,6 \\
25 & 0,38 & 1,99 & 14,9 \\
35 & 0,93 & 1,42 & 16,3 \\
45 & 0,65 & 1,67 & 17,4 \\
65 & 0,98 & 1,39 & 16,8 \\
90 & 0,98 & 1,39 & 16,4 \\
\hline
\end{tabular}


Nesse estudo foram executadas três colunas isoladas de reforço, sendo uma na condição inundada (Coluna Compactada 1), outra na condição do solo natural (não inundada, denominada pela autora como Coluna Compactada 2) e uma terceira constituída de uma mistura solo e brita (Coluna Solo e Brita) para comparação com as de solo laterítico compactado.

Após a execução das colunas, foram realizados ensaios de prova de carga estática (ou lenta) em cada uma delas, cujos resultados (para as colunas de solo laterítico compactado) encontram-se expressos pelas curvas tensão $x$ deslocamento da Figura 3.6 abaixo.

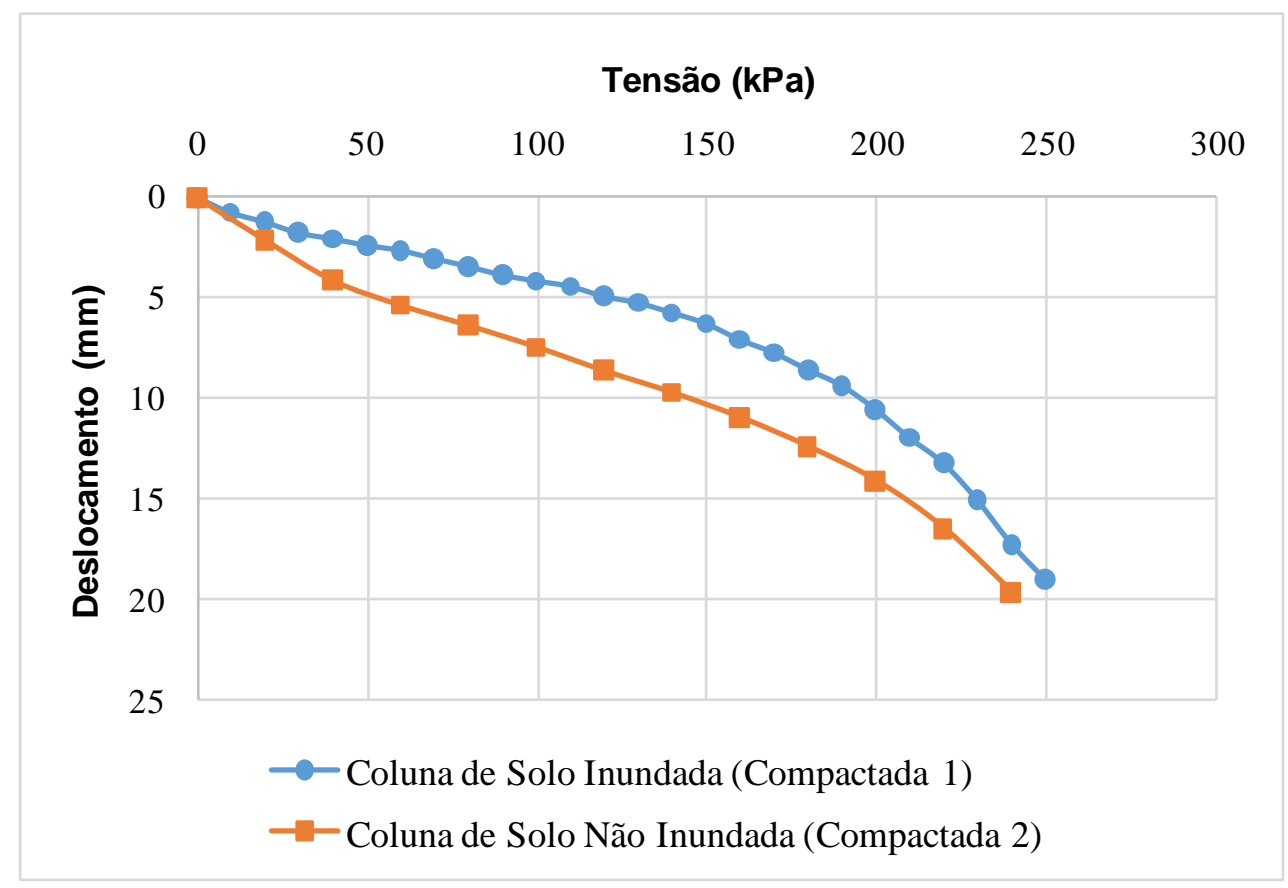

Figura 3.6: Curvas tensão $x$ deslocamento experimentais para as colunas de solo laterítico compactado. Adaptado de Freitas (2016).

A partir da análise dos dados obtidos no ensaio de prova de carga, fez-se uma estimativa do módulo de deformabilidade equivalente $(E)$ e das tensões de ruptura e admissíveis.
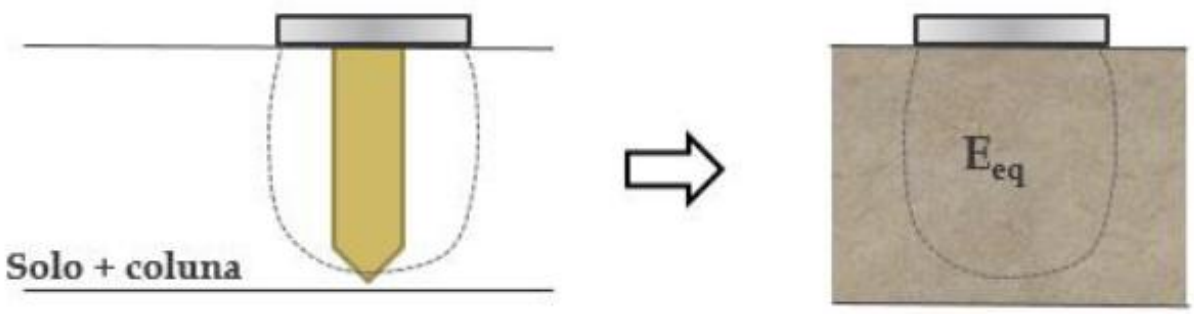

Figura 3.7: Simplificação considerada para o cálculo do módulo de deformabilidade equivalente. Fonte: Freitas (2016) 
Tabela 3.5: Valores estimados de Módulo de Deformabilidade e tensões de ruptura e admissível para as colunas e maciço natural (solo sem reforço). Fonte: Freitas (2016).

\begin{tabular}{|cccc|}
\hline Ensaio & $\boldsymbol{\sigma}_{\text {rup }}(\mathbf{k P a})$ & $\boldsymbol{\sigma}_{\text {adm }}(\mathbf{k P a})$ & $\boldsymbol{E}_{\text {adm }}(\mathbf{M P a})$ \\
\hline Coluna de solo compactado 1 & 268 & 134 & 27,33 \\
Coluna de solo compactado 2 & 265 & 132,5 & 21,93 \\
Solo sem reforço com sucção de 6 $\mathrm{kPa}$ & 100 & 50 & 8,54 \\
\hline
\end{tabular}

Por fim, para noção da geometria final da coluna após sua execução em campo, a autora realizou modelos físicos em escala reduzida onde houve a cravação estática de um pilão metálico de diferentes geometrias e posterior escarificação para medida das dimensões finais.

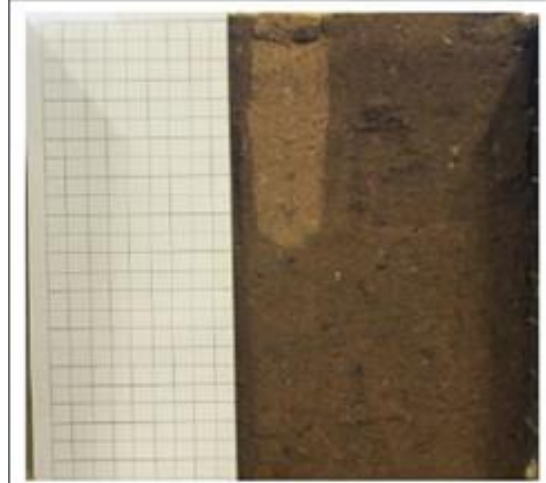

Pilão Cônico

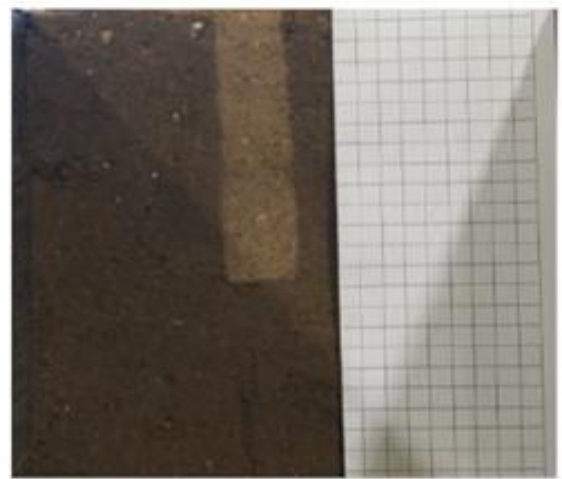

Pilão Cilíndrico

Figura 3.8: Geometrias das colunas em modelo reduzido após escarificação. Fonte: Freitas (2016)

Os pilões utilizados foram o de ponta cilíndrica e de ponta cônica com $30^{\circ}$ de ápice, ambos com diâmetro de 25,4 milímetros. A profundidade cravada (antes da compactação) foi de 12,5 centímetros. As medidas obtidas após a escarificação são ilustradas na Tabela 3.6 abaixo.

Tabela 3.6: Resultados obtidos da cravação estática e compactação do modelo em escala reduzida. Fonte: Freitas (2016).

\begin{tabular}{|ccc|}
\hline & Ponta Cilíndrica & Ponta Cônica \\
\hline Profundidade $(\mathrm{cm})$ & 13,2 & 12,1 \\
Diâmetro médio $(\mathrm{cm})$ & 3,13 & 3,29 \\
Acréscimo do diâmetro (\%) & $23 \%$ & $30 \%$ \\
Volume $\left(\mathrm{cm}^{3}\right)$ & 101,6 & 102,9 \\
$\rho\left(\mathrm{g} / \mathrm{cm}^{3}\right)$ & 1,77 & 1,75 \\
\hline
\end{tabular}


Para realização do presente estudo, foi utilizado o solo pertencente ao campo experimental de fundações do Campus I da Escola de Engenharia de São Carlos da Universidade de São Paulo. O local de retirada das amostras encontra-se ilustrado nas Figura 4.1 e 4.2 abaixo e foi escolhido pelo fato de encontrar-se em uma cota mais profunda, possibilitando assim a retirada de um material menos revolvido e fora da camada de aterro (encontrada ao longo de toda a extensão do campo experimental, para nivelamento de sua superfície).

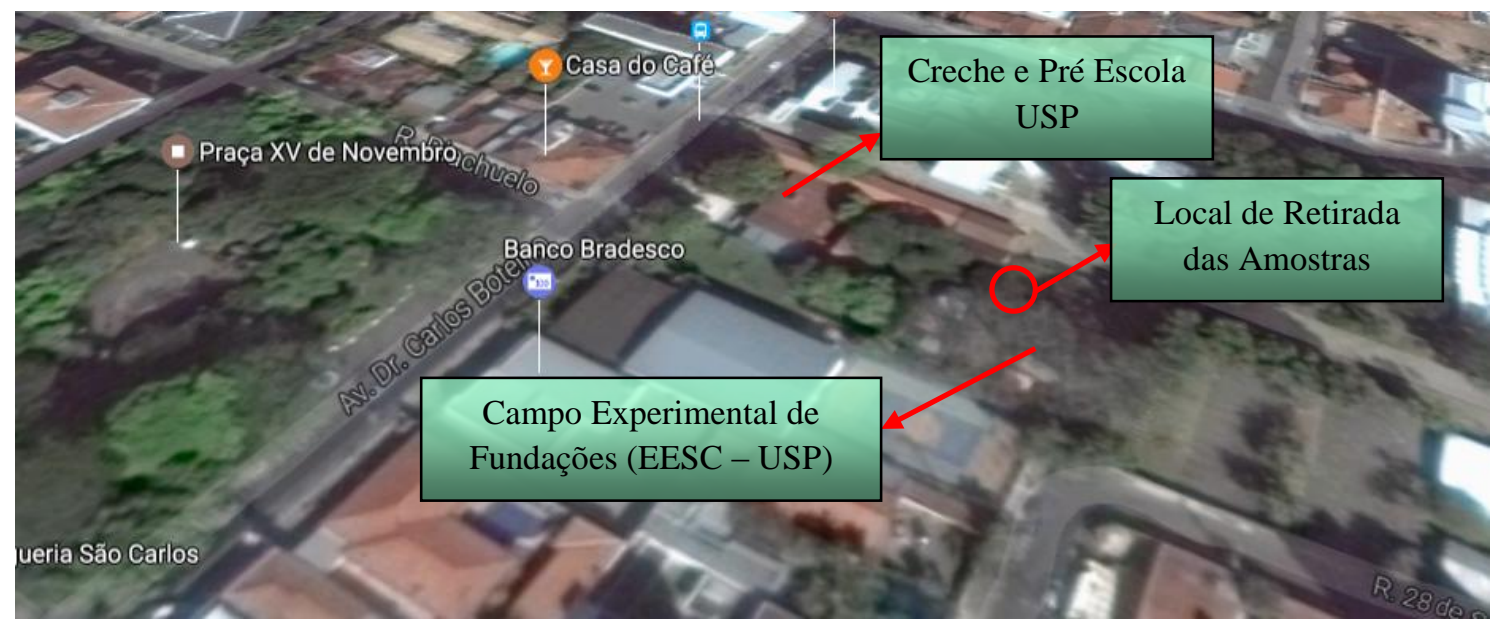

Figura 4.1: Locação estimada da amostragem realizada para execução dos ensaios. Fonte: Google Maps, acesso em 03/04/2017.

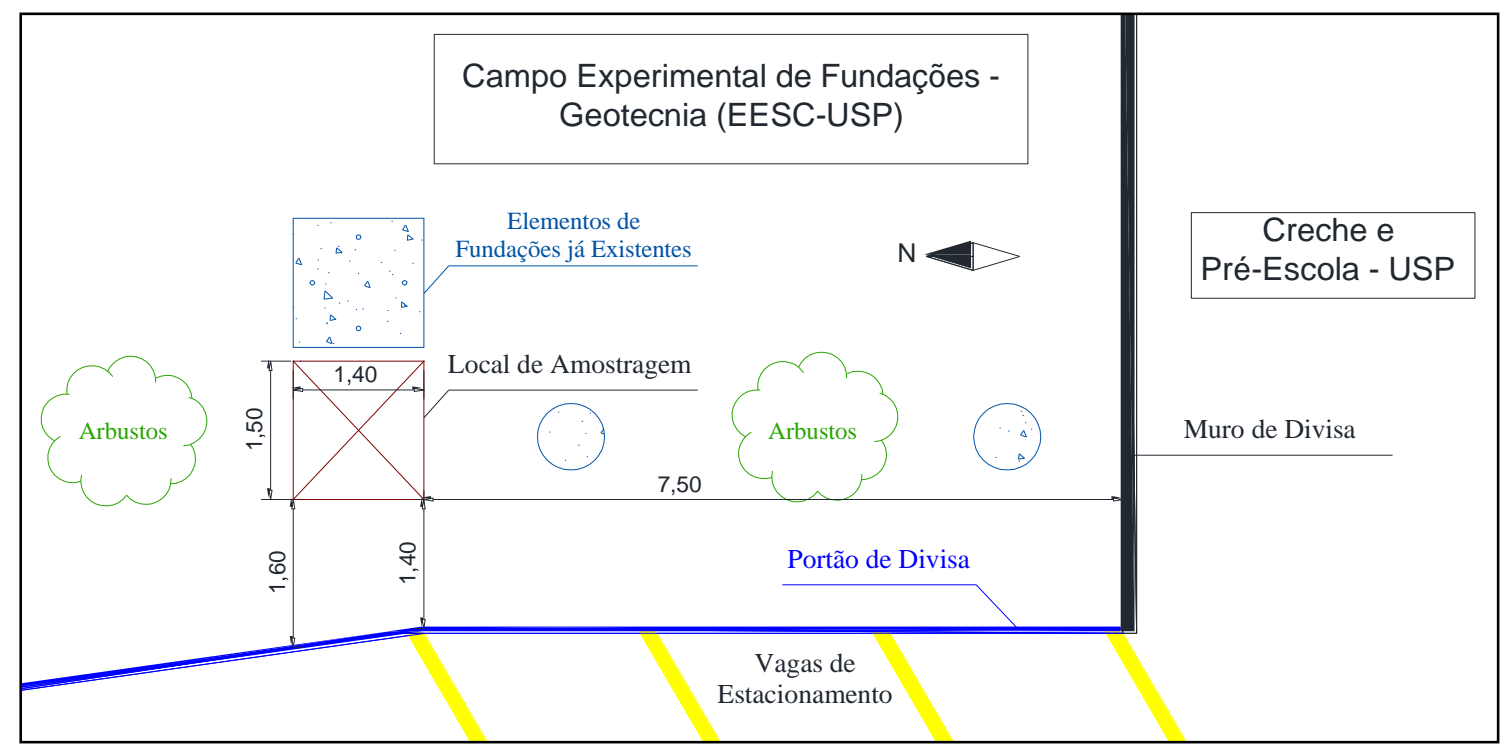

Figura 4.2: Croqui esquemático, em planta, do local de amostragem (dimensões em metros). 


\subsection{Ensaios de Laboratório}

Em uma primeira etapa de ensaios em laboratório, realizados no Laboratório de Mecânica dos Solos do Departamento de Geotecnia da EESC (USP), foram amostrados cerca de $150 \mathrm{~kg}$ de solo, a partir do qual foram realizados ensaios de caracterização, de compactação, edométricos e simulações de modelos físicos reduzidos não centrifugados. Todo o solo foi secado em estufa (com temperatura não superior a $40{ }^{\circ} \mathrm{C}$ ), destorroado, peneirado em peneira de malha $n^{\circ} 4$ (abertura $4,75 \mathrm{~mm}$ ), homogeneizado em betoneira e posteriormente ensacado para realização dos ensaios.
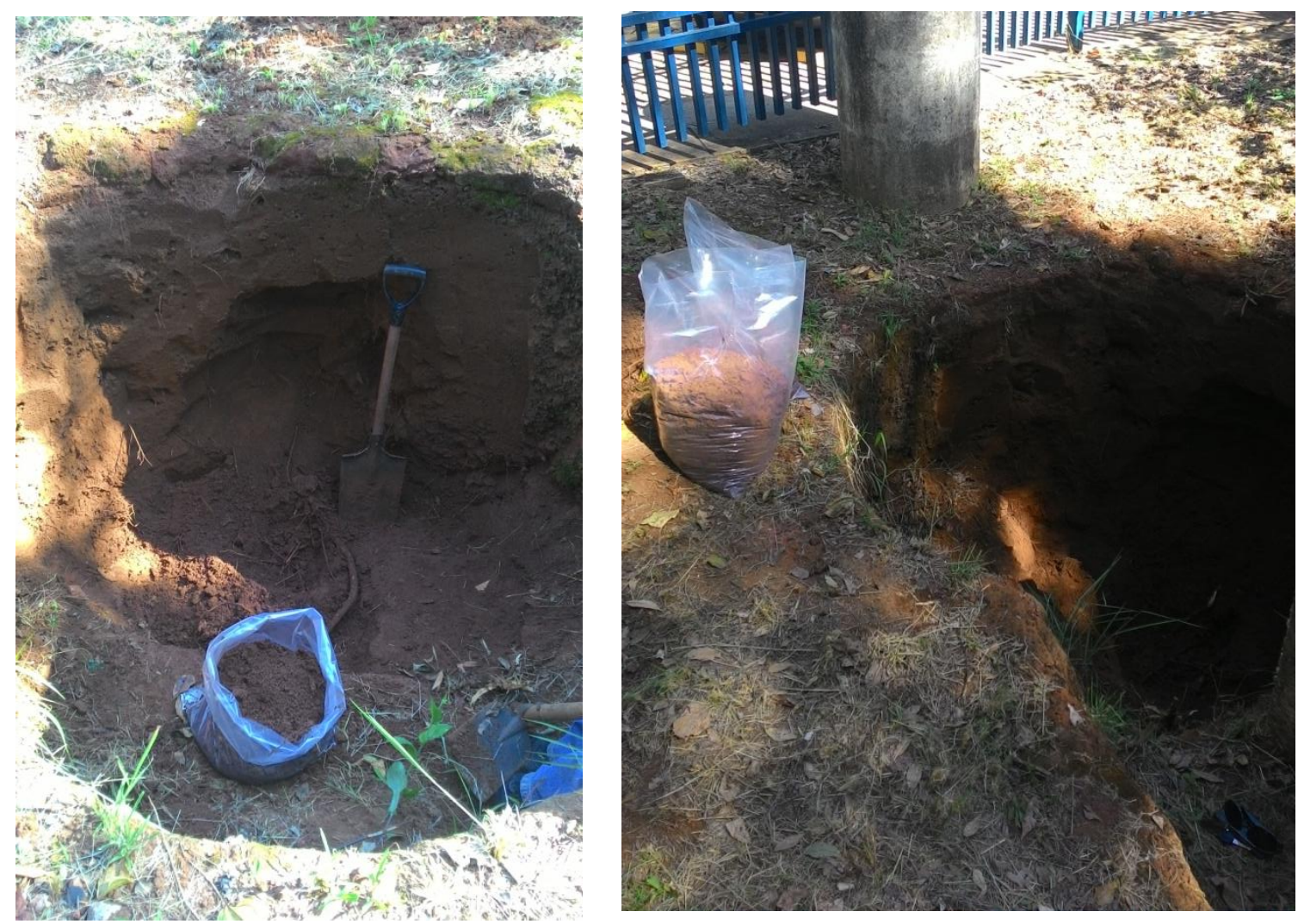

Figura 4.3: Procedimento de retirada de amostras deformadas para a realização dos ensaios.

\subsubsection{Ensaios de Caracterização}

Por mais estudado e caracterizado que um determinado solo tenha sido (como no caso do Campo Experimental de Fundações), é sempre necessário e prudente um novo estudo de caracterização do mesmo, anteriormente à execução dos ensaios e modelagens, para que seja 
assegurada a fidedignidade dos parâmetros utilizados. Para isso, realizou-se, no Laboratório de Mecânica dos Solos do Departamento de Geotecnia da Escola de Engenharia de São Carlos, os ensaios de classificação tradicionais de granulometria conjunta (ABNT NBR 7181/1984), massa específica dos sólidos (ABNT NBR 6508/1984), limite de liquidez (ABNT NBR 6459/1984) e limite de plasticidade (ABNT NBR 7180/1984).

\subsubsection{Ensaio de Compactação}

Devido à importância de um processo de compactação bem executado, para que sejam assegurados seus benefícios e redução do efeito da colapsibilidade do solo, foi também realizado um ensaio de compactação com energia Proctor normal (ABNT NBR 7182/1986) para obtenção dos parâmetros ótimos de compactação do solo estudado. Tal ensaio foi de suma importância para desenvolvimento da pesquisa, uma vez que os parâmetros ótimos obtidos no mesmo serviram de base para realização das modelagens (principalmente em centrífuga) e ensaios relacionados à colapsibilidade.

\subsubsection{Ensaios Edométricos}

Sabe-se que o solo local apresenta comportamento colapsível. O pertencente ao campo experimental, por exemplo, apresenta porosidades na ordem de 50\% (extremamente porosos) e cujos poros apresentam grandes dimensões (tornando-se difícil permanecer na condição saturada). Dessa forma, a compreensão do efeito do colapso sobre o mesmo torna-se demasiadamente importante para predição e entendimento de seu comportamento.

Tendo tal situação em vista, ainda no Laboratório de Mecânica dos Solos, foram executados ensaios edométricos simples e duplos para investigar o potencial de colapso do solo estudado a diferentes graus de compactação. 


\subsection{Modelagem Física a $1 \mathrm{~g}$}

Também no Laboratório de Mecânica dos Solos do Departamento de Geotecnia da Escola de Engenharia de São Carlos, foram executados alguns mini-modelos físicos não centrifugados, em uma caixa de madeirite de 24 por 30 centímetros de base e 30 centímetros de altura. O intuito da realização desses modelos foi o de reprodução das condições de campo (a uma escala dez vezes menor), de modo a conferir uma noção quanto à execução do ensaio em centrífuga, suas dificuldades e otimização, tal que fosse conhecido e racionalizado o processo executivo dos ensaios que seriam realizados a posteriori na Universidade Estadual do Norte Fluminense.

Para realização dos ensaios não centrifugados, tentou-se simular as condições presenciadas em campo, testando alguns graus de compactação e sempre com um teor de umidade $3 \%$ inferior ao ótimo (obtido a partir do ensaio de compactação). A caixa foi dividida em alturas iguais e conhecidas e, então, foi calculada a massa de solo para que, nestes parâmetros citados, preenchesse exatamente aquele volume estipulado, garantindo assim o grau de compactação necessário, conforme descrito a seguir.

$$
\begin{gathered}
G C=\frac{\rho_{d, \text { compactação }}}{\rho_{d, \text { máx }}} \rightarrow \rho_{d, \text { compactação }}=G C \cdot \rho_{d, \text { máx }} \\
\rho=\rho_{d, \text { compactação }} \cdot(1+w)
\end{gathered}
$$

Sendo, por definição, a massa específica a relação entre a massa e o volume, para um determinado volume a ser ocupado, conhecendo-se a massa específica requerida, tem-se, portanto, a massa de solo cabível ao mesmo. Como a caixa do ensaio apresenta $30 \mathrm{~cm}$ de altura e uma seção transversal de $24 \mathrm{~cm}$ por $30 \mathrm{~cm}$, fez-se uma divisão, em sua altura, em 12 camadas de 2,5 cm de altura cada, conforme ilustrado na Figura 4.4 abaixo.

Dessa forma, para cada camada, sabe-se a massa de solo necessária, a uma determinada umidade, para que seja preenchido o volume estipulado atendendo ao requisito de grau de compactação desejado. Ou seja:

$$
\rho=\frac{m}{V}=\frac{m_{\text {solo por camada }}}{V_{\text {por camada }}}=\frac{m_{\text {solo por camada }}}{2,5.24 .30}\left[\mathrm{~g} / \mathrm{cm}^{3}\right]
$$

Sendo a massa específica seca calculada pela Expressão 4.1. 

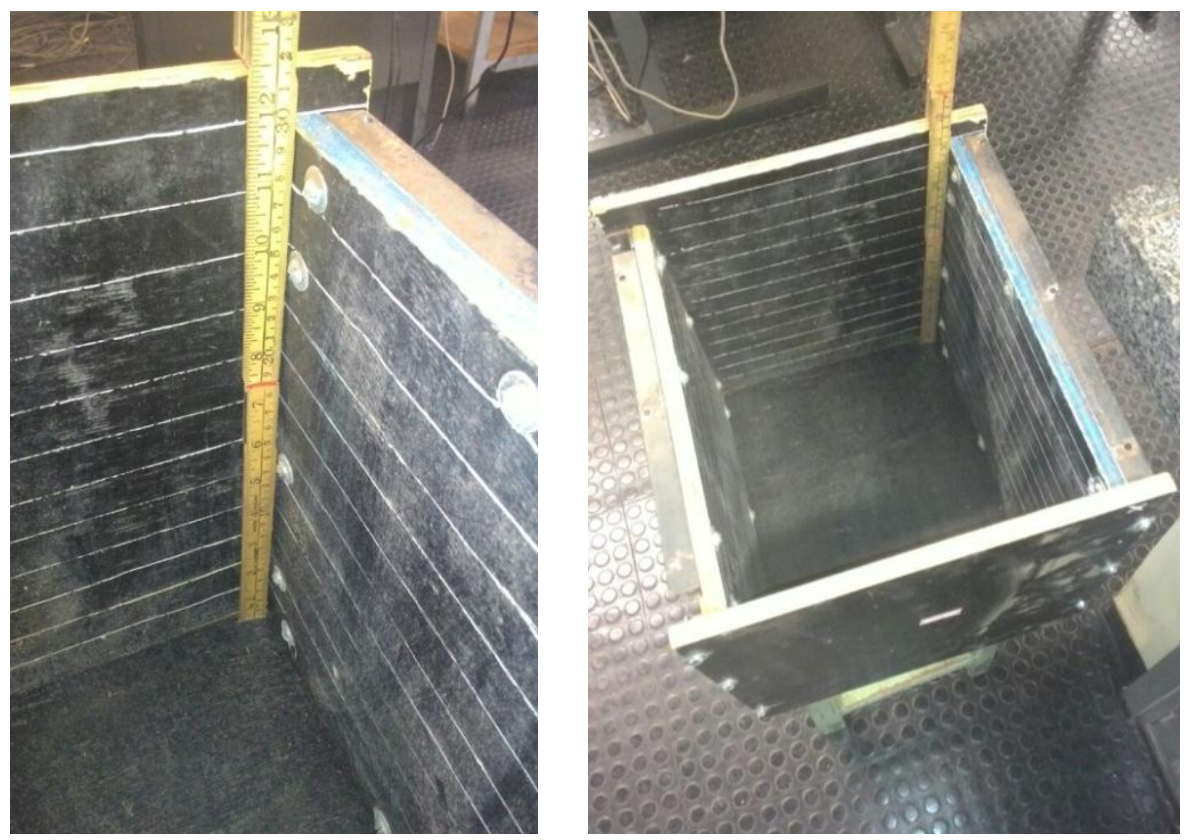

Figura 4.4: Caixa de madeirite utilizada para execução do modelo físico não centrifugado.

Feito isso, executou-se a cravação da coluna metálica com uma prensa, a uma velocidade constante, a qual serviu de forma para o furo a ser compactado. A coluna utilizada é de alumínio e possui seção transversal circular de $20 \mathrm{~mm}$ de diâmetro e comprimento final cravado de $200 \mathrm{~mm}$. Sua ponta é cônica, com ápice de $30^{\circ}$, conforme Figura 4.5 a seguir.

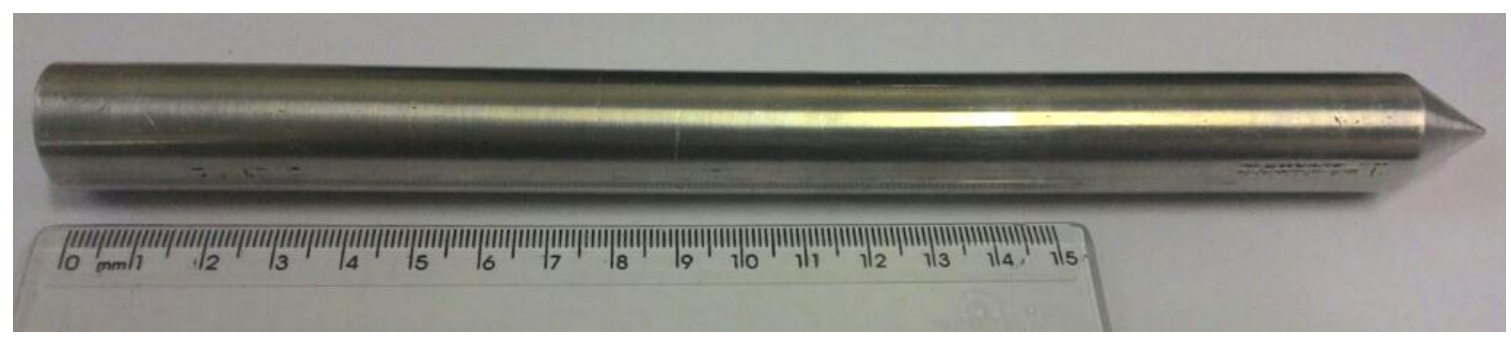

Figura 4.5: Coluna metálica utilizada como forma para execução do furo a ser compactado com o solo laterítico.

Após sua cravação, retirou-se a coluna metálica e em seguida, com o auxílio de um soquete compactador adaptado e galgado em alturas conhecidas, procedeu-se o processo de compactação da coluna, também com controle do processo de compactação por volume. 


\subsection{Modelagem em Centrífuga Geotécnica}

Para realização dessa segunda etapa, foram amostrados cerca de $400 \mathrm{~kg}$ de solo, do mesmo local anteriormente locado. Todo o solo foi disposto em bandejas e seco ao ar (temperatura ambiente), peneirado e batido por 15 minutos em betoneira para homogeneização. Após esse procedimento, foram separados em porções de $5 \mathrm{~kg}$ para adequação do teor de umidade requerido e então novamente ensacado para transporte à centrífuga.

A modelagem física foi realizada através da centrífuga de viga localizada na Universidade Estadual do Norte Fluminense, na cidade de Campos dos Goytacazes, no estado do Rio de Janeiro (ilustrada na Figura 2.42 do presente trabalho).

Os modelos ensaiados foram montados em um container cilíndrico de $464 \mathrm{~mm}$ de diâmetro e $475 \mathrm{~mm}$ de altura, conforme ilustrado na Figura 4.6 a seguir. $\mathrm{O}$ efeito de borda foi considerado desprezível a partir de uma distância equivalente a quatro vezes o diâmetro da coluna medida a partir da parede do container $(4 d)$.
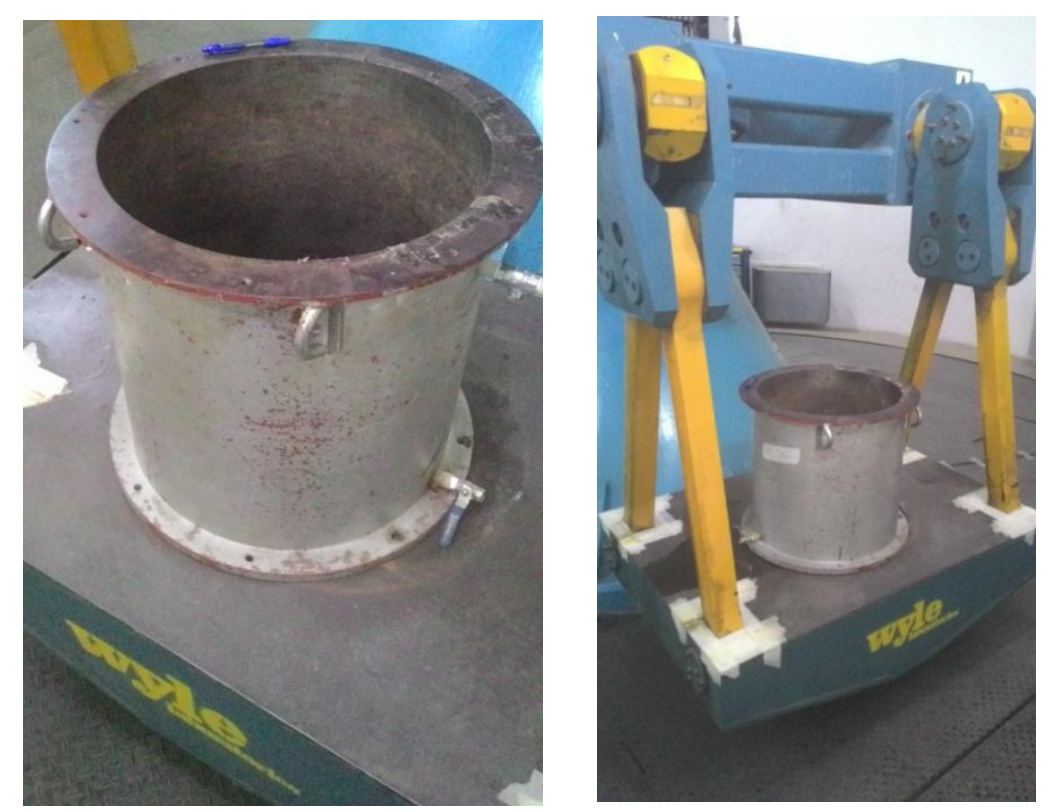

Figura 4.6: Container cilíndrico utilizado para os ensaios (Centrífuga da UENF).

Para preenchimento do container, foram simuladas as condições de campo, atendendo a um grau de compactação $(G C)$ e uma variação do teor de umidade ótimo $(\Delta w)$ pré-estipulados como representativos do campo. O container foi forrado em sua lateral por um acetato 
transparente, com divisões de $50 \mathrm{~mm}$ de altura nas nove primeiras camadas e uma última divisão de $25 \mathrm{~mm}$ (para controle do volume no processo de compactação).
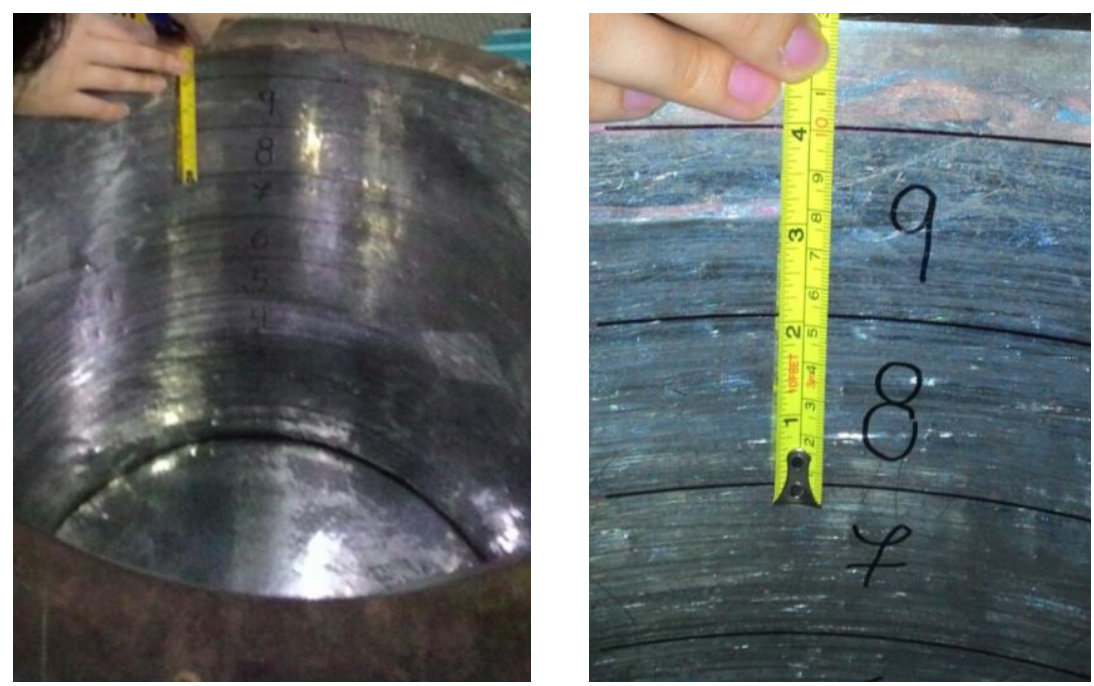

Figura 4.7: Acetato com marcações para controle do processo de compactação por volume.

As colunas de reforço foram executadas de maneira análoga à comentada no item 4.2 do presente trabalho, tendo $20 \mathrm{~mm}$ de diâmetro e um comprimento cravado de $200 \mathrm{~mm}$. As malhas de colunas foram locadas de acordo com placas gabarito pré-confeccionadas com a posição exata das colunas de reforço. Sua cravação deu-se através de uma placa de cravação, nivelada, sobre a qual um macaco hidráulico fornecia, juntamente com um pórtico de reação fixado ao container, a pressão necessária para cravar o sistema de colunas metálicas.

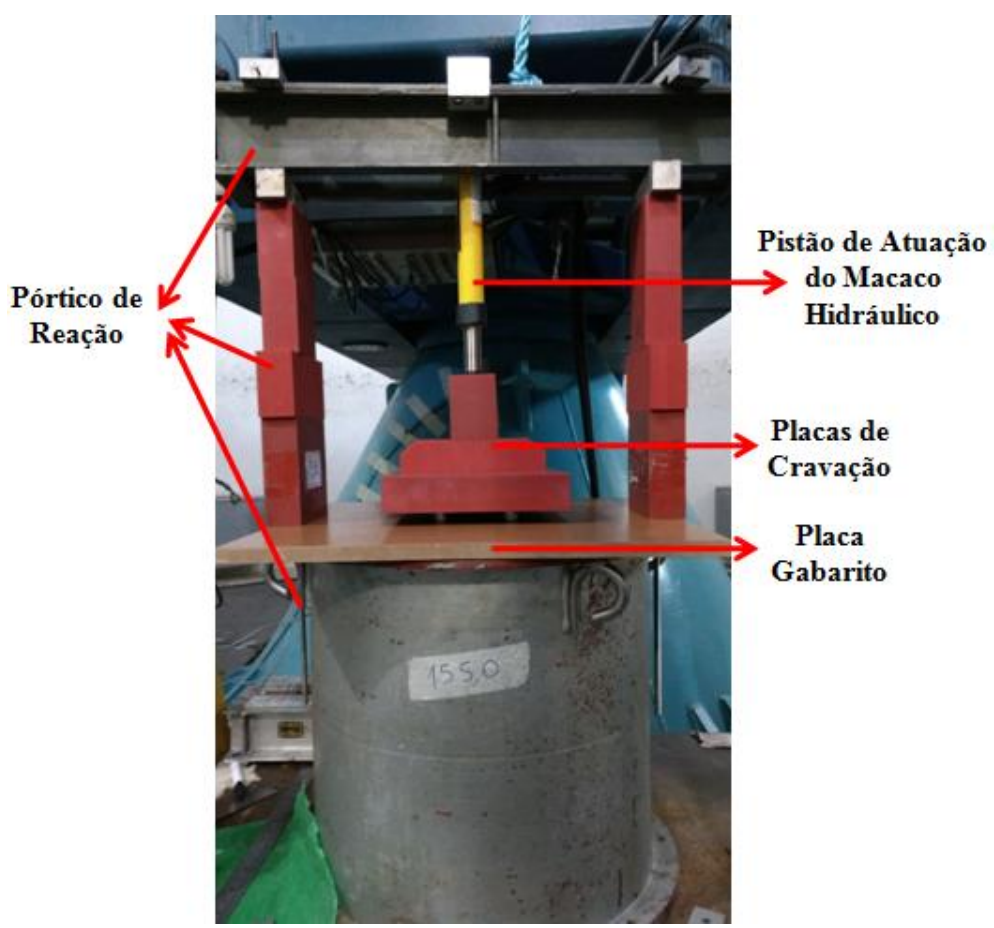

Figura 4.8: Elementos componentes do sistema de cravação das colunas metálicas. 


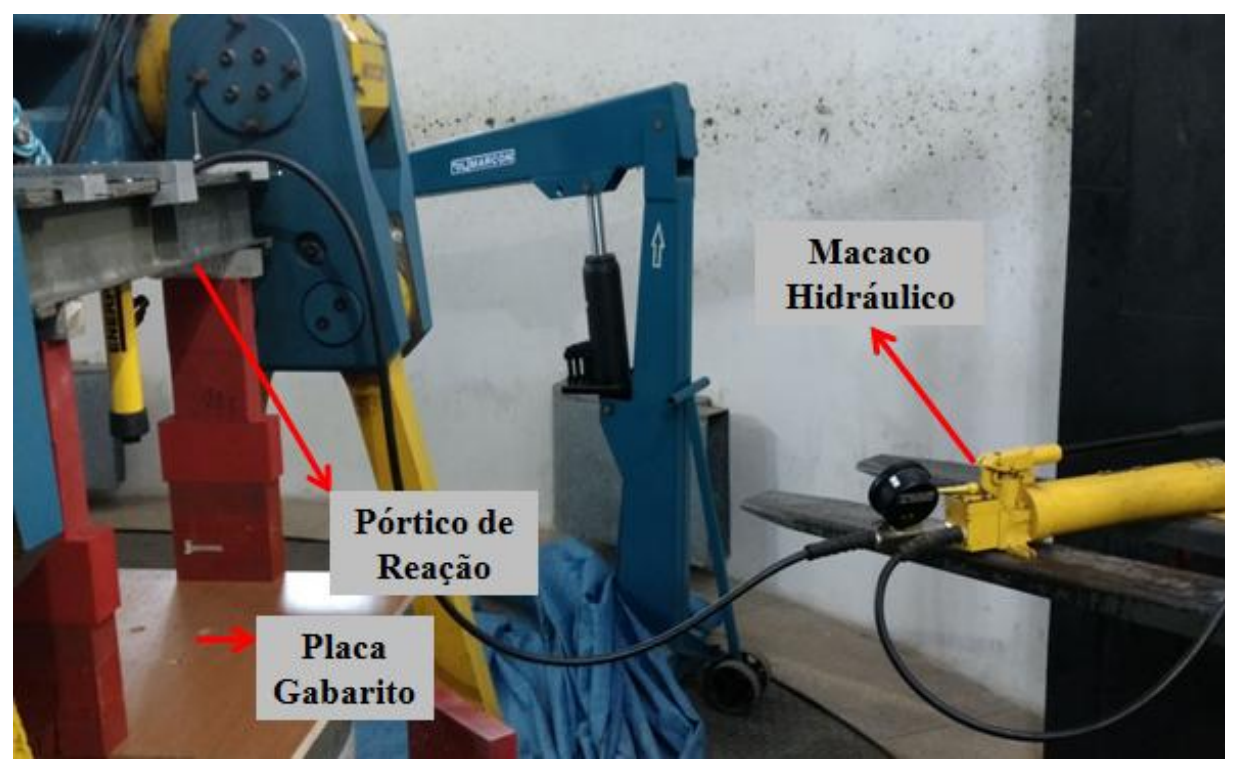

Figura 4.9: Sistema de cravação das colunas metálicas.

Posteriormente à cravação das colunas, desmontou-se o sistema de cravação e, uma a uma, foram retiradas as colunas metálicas e então compactadas as colunas de solo laterítico para reforço. Para a simular o carregamento de uma fundação direta, foi utilizada uma placa circular de 200 mm de diâmetro, de material chempoxy (muito leve e resistente à compressão), conforme ilustrado na Figura 4.10 a seguir.

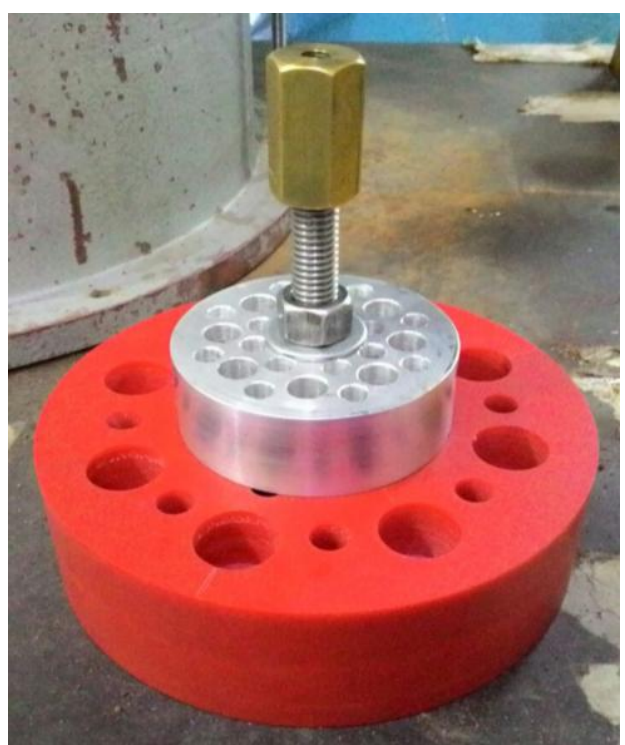

Figura 4.10: Placa de atuação, de 20 centímetros de diâmetro, simulando o elemento de fundação direta.

Dentre as diversas configurações de malha possíveis, foi escolhida aquela que melhor se adequou ao espaço disponível no container, tanto em termos de formato da malha quanto em termos de profundidade e espaçamento das colunas. Todos os ensaios foram rotacionados a uma 
aceleração equivalente a 10 vezes a aceleração da gravidade $(10 \mathrm{~g})$. A seguir estão indicadas as diferentes disposições dos ensaios realizados.

\subsubsection{Solo sem reforço}

Primeiramente, foi realizado o ensaio do solo sem nenhum reforço (sem nenhuma coluna), para verificar seu deslocamento tal como ocorreria na situação original em campo e depois então ser possível a comparação com os diferentes reforços dispostos, sob um mesmo carregamento aplicado. Para o solo sem reforço, foram realizados os ensaios tanto para a condição natural de campo (não saturada) quanto para a condição inundada.

A condição inundada foi simulada de maneira que a sucção fosse nula ou desprezível. Para isso, após a compactação do solo no container (simulando os parâmetros de campo), foi adicionado um volume de água até que o solo encontrasse-se próximo de sua saturação (sucção matricial nula ou próxima).

Na Figura 4.11 a seguir, são ilustrados em planta o limite para o efeito de borda considerado como quatro vezes o diâmetro $d$ da coluna de reforço (4d) e a placa de atuação de diâmetro $B=200 \mathrm{~mm}$.

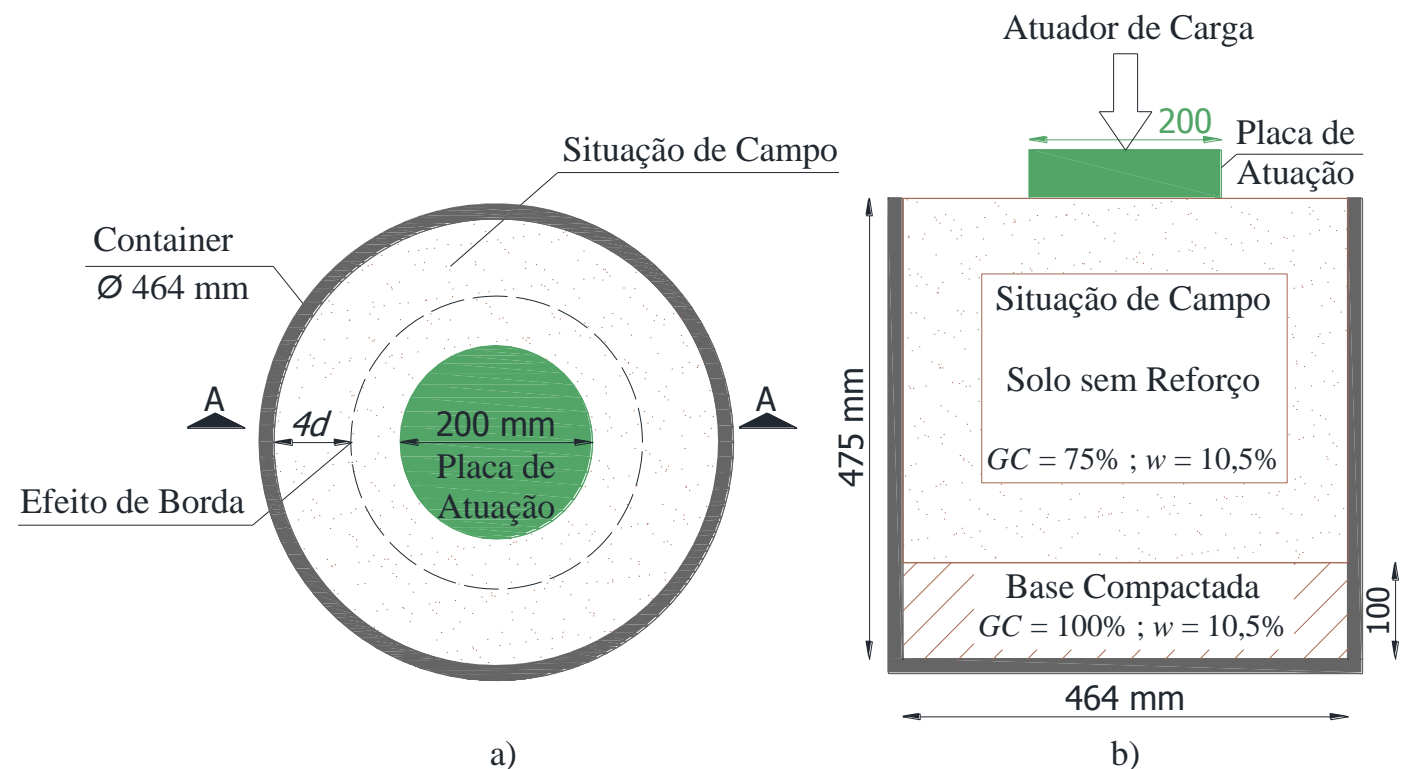

Figura 4.11: Esquema ilustrativo dos ensaios a serem realizados em solo sem reforço, vista em planta (a) e em corte A-A (b), com dimensões em milímetros. 
Analogamente ao modelo não centrifugado, o controle de compactação foi realizado por volume, calculando-se a massa necessária para preenchimento do volume de cada camada definida, nos parâmetros pré-estabelecidos como representativos do campo. Entre cada camada era realizado o processo de escarificação para melhor entrosamento entre as camadas adjacentes.
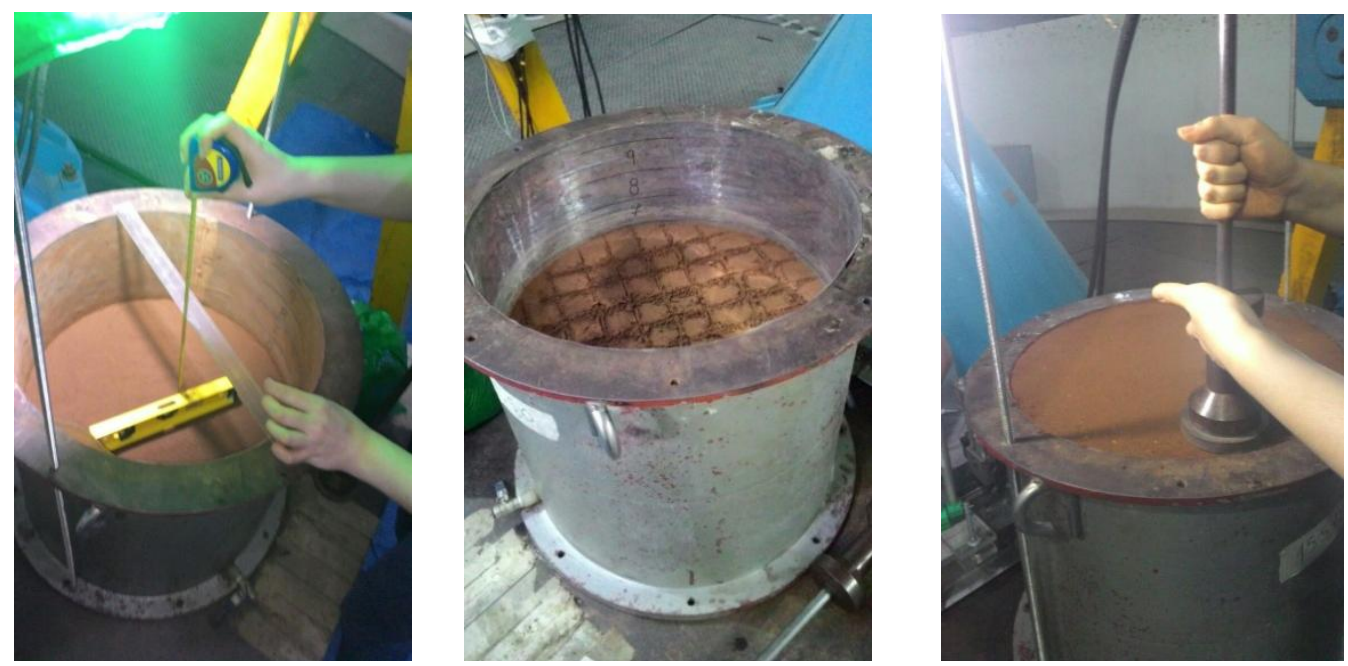

Figura 4.12: Processo de compactação do container, com controle de volume.

Depois de preenchido o container nos parâmetros requeridos, foi montado o sistema de atuação e centralizou-se, com auxílio de nível a laser, a placa de atuação. Posteriormente, a instrumentação foi instalada para proceder ao início do voo. Como instrumentação, foram utilizados duas células de carga (de capacidades $1.000 \mathrm{lbf} 3.000 \mathrm{lbf}$ ) e um LVDT para medida do deslocamento vertical sofrido pelo sistema.
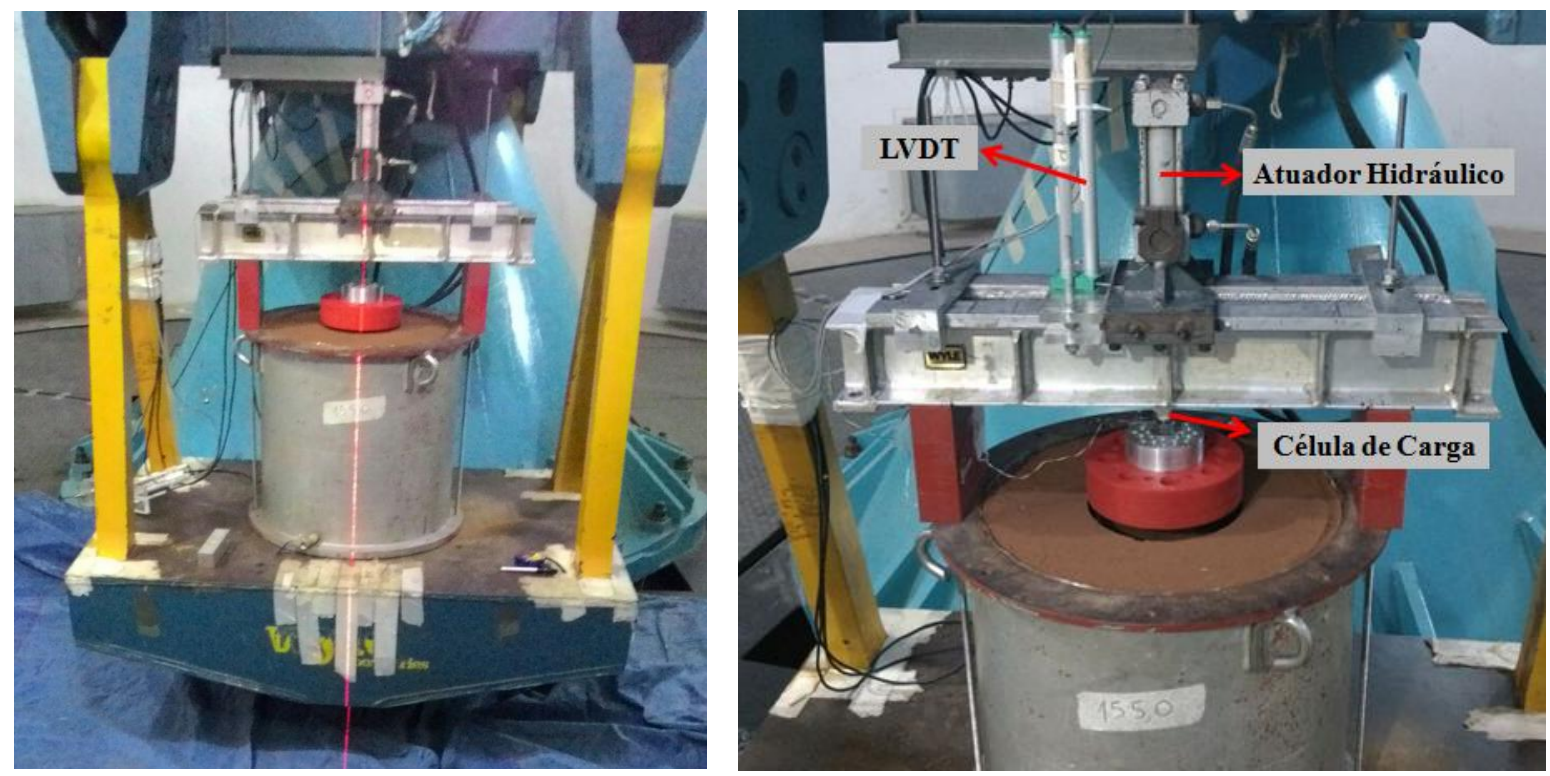

Figura 4.13: Centralização da placa de atuação com nível a laser (à esquerda) e locação da instrumentação utilizada no ensaio (à direita). 
Foi considerada a superfície do solo (interface entre o solo e a placa de atuação) como superfície para cálculo do raio a ser inserido no software de operação da centrífuga. A aceleração foi equivalente a 10 vezes a aceleração da gravidade ( $10 \mathrm{~g}$ ou $58 \mathrm{RPM})$. No cesto oposto ao do container de ensaio, foram colocadas, em um container retangular, anilhas de ferro totalizando a massa equivalente do container ensaiado para contrabalanceamento de pesos em voo.

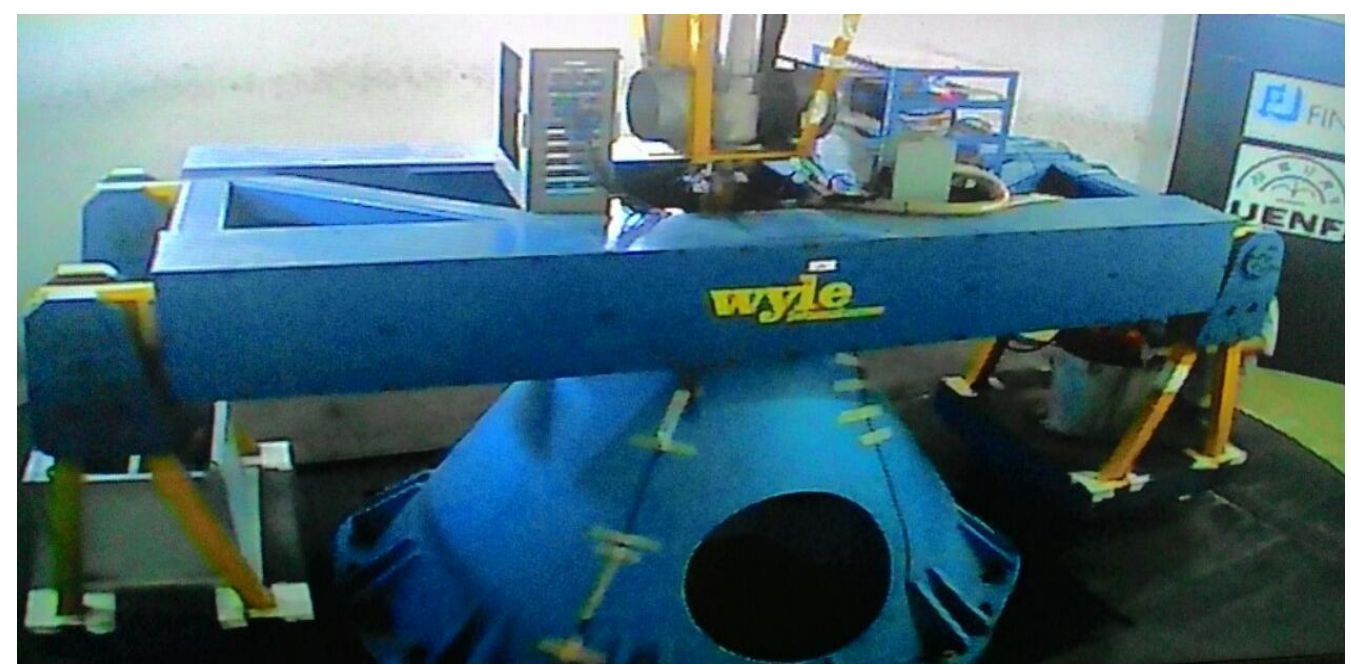

Figura 4.14: Imagem da câmera da centrífuga sendo preparada para início do voo.

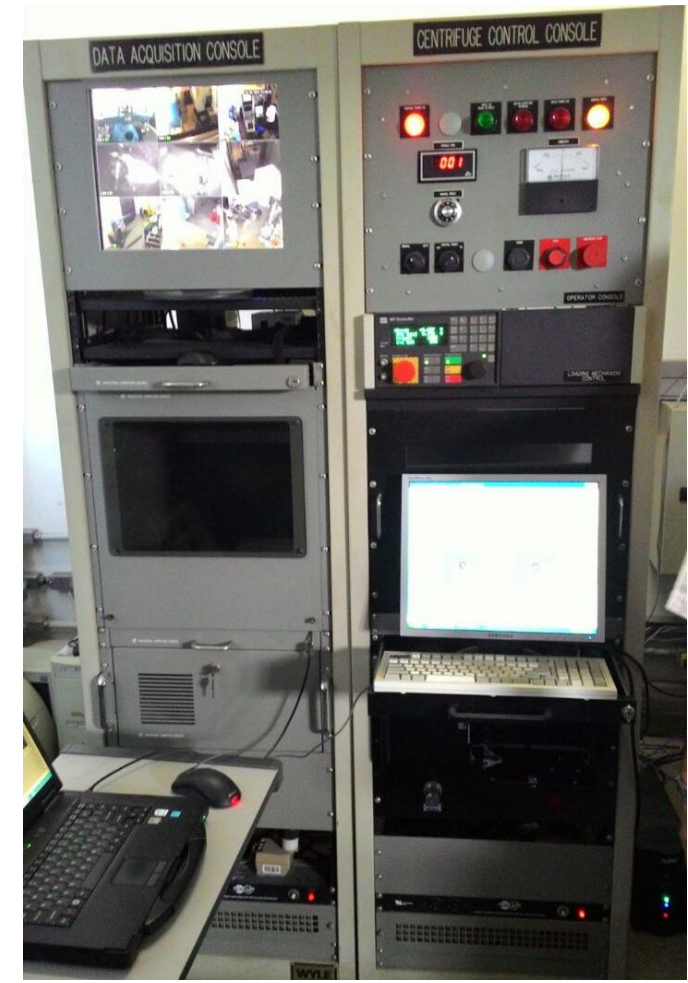

Figura 4.15: Equipamento para controle e operação da centrífuga geotécnica. 


\subsubsection{Malha de colunas com espaçamento 4d}

Primeiramente, foi cogitado um espaçamento entre eixos de três vezes o diâmetro $d$ da coluna. Contudo, para uma malha triangular, a configuração da malha e a quantidade de colunas sob a placa de atuação seriam as mesmas do que com espaçamento de 4 vezes o diâmetro. Assim sendo, optou-se por ensaiar um espaçamento entre as colunas, de eixo a eixo (longitudinal), equivalente a quatro vezes seu diâmetro $d(4 d)$. Como o diâmetro das colunas equivale a aproximadamente $20 \mathrm{~mm}$, o espaçamento entre eixos foi equivalente, portanto, a 80 mm. A profundidade cravada das colunas metálicas foi equivalente à dimensão B da placa de atuação $(200 \mathrm{~mm})$.

A melhor disposição dentre as consideradas para tal espaçamento, com as dimensões do container e da placa disponíveis, foi a referente a uma malha triangular. Os esquemas ensaiados foram dois: um com o reforço pelas colunas apenas na região de projeção da placa e outro com reforço tanto na região da placa quanto em sua adjacência (exceto na região onde o efeito de borda é atuante), conforme ilustrado nas Figuras 4.16 e 4.17 a seguir.

O objetivo da realização de ambos os ensaios foi o de verificar o aumento da capacidade de carga do sistema quando o reforço está disposto, também, além do elemento de fundação (considerando uma propagação de tensões da proporção 2:1). Além disso, foi também testada a condição inundada para a malha com 13 colunas (colunas não só na projeção da placa mas também em sua adjacência).

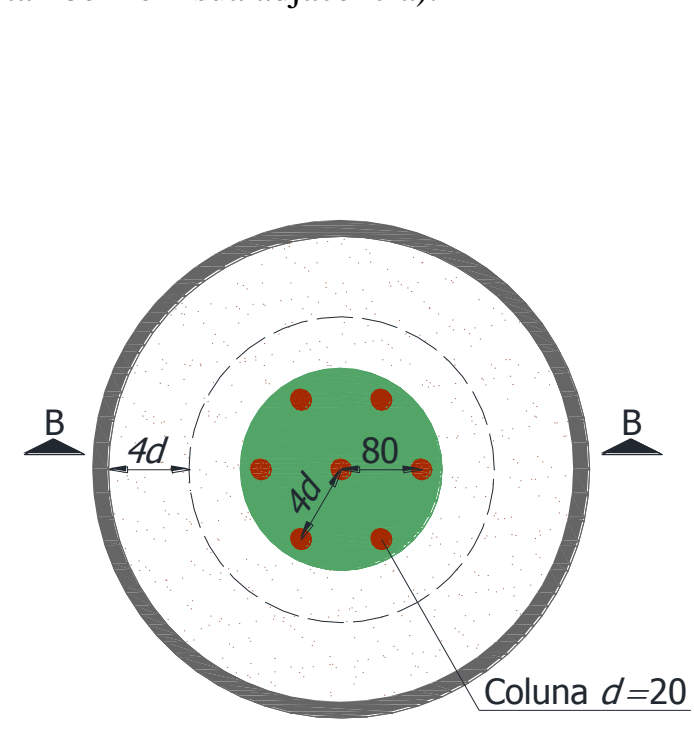

a)

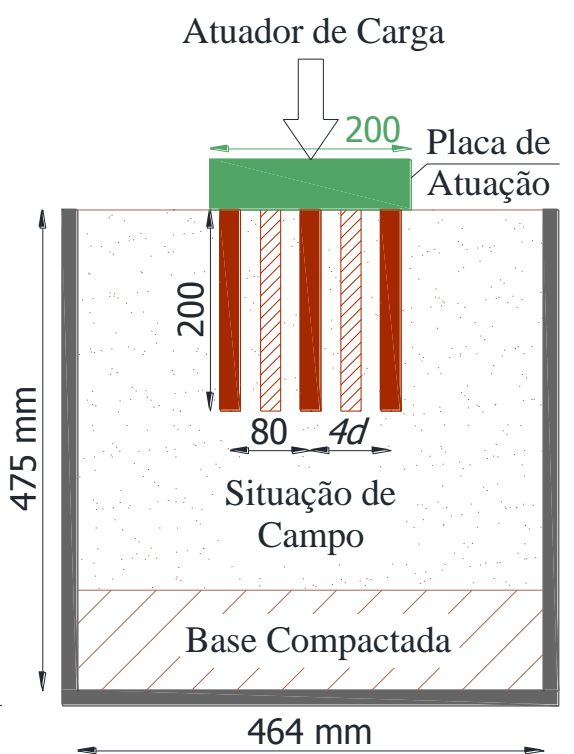

b)

Figura 4.16: Malha triangular com 7 colunas, apenas na região de projeção da placa de atuação, com espaçamento entre eixos de $4 d$. Vista em planta (a) e em corte B-B (b). Medidas em centímetros. 


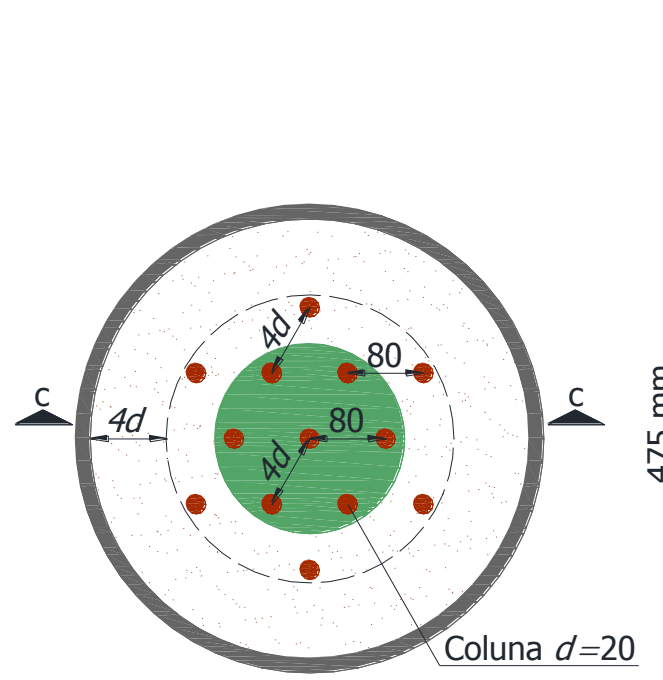

a)

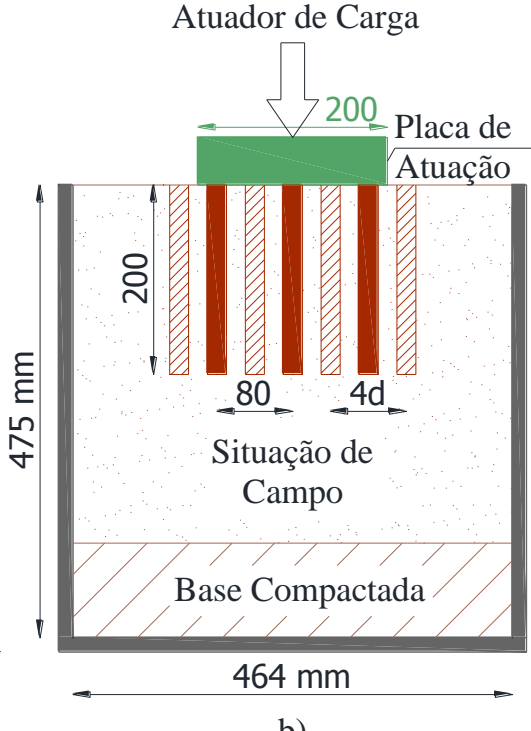

b)

Figura 4.17: Malha triangular com 13 colunas, tanto na região de projeção da placa de atuação quanto em seu entorno, com espaçamento entre eixos de $4 d$. Vista em planta (a) e em corte C-C (b). Medidas em milímetros.

Para a malha triangular com espaçamento $4 d$, têm-se uma célula unitária hexagonal conforme exposto na Figura 4.18 a seguir.

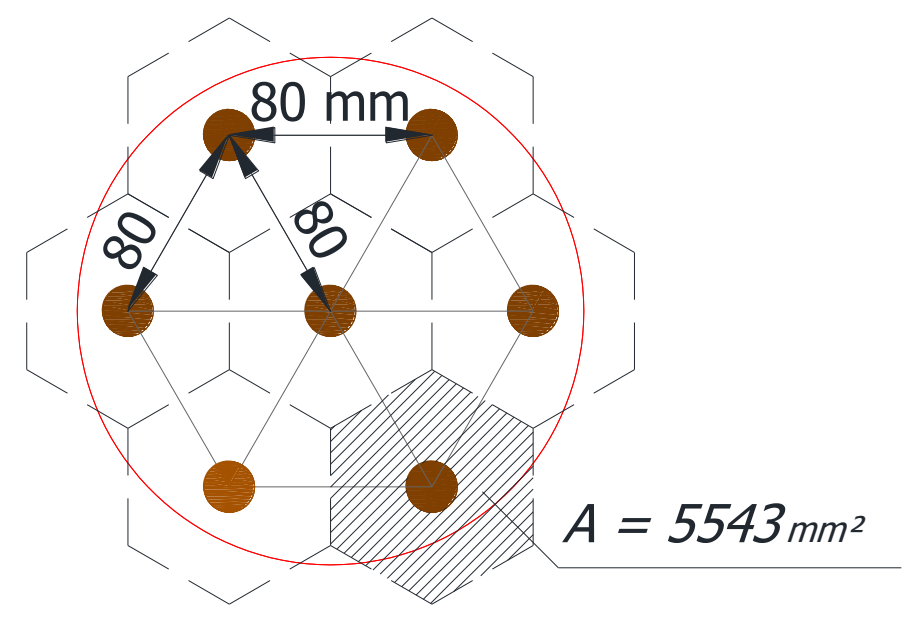

Figura 4.18: Célula unitária hexagonal da malha triangular com espaçamento $4 d$.

$\mathrm{O}$ esquema de célula unitária acima ilustrado aplica-se tanto para o esquema com 7 colunas tanto para o esquema com 13 colunas. A taxa de cobertura ou área de substituição $(\alpha)$ pode ser calculada através Expressão 2.13, em que:

$$
\alpha(\%)=\frac{A_{p}}{A} \cdot 100=\frac{\left(\pi \cdot 20^{2} / 4\right)}{5543} .100=5,67 \%
$$


Para execução da malha no container, foram utilizadas placas gabarito com a locação das colunas de acordo com sua geometria e espaçamento. A placa gabarito era fixada ao container, as colunas eram locadas em prumo e então cravadas pela atuação do macaco hidráulico e auxílio da placa de cravação (conforme ilustrado na Figura 4.19 a seguir).

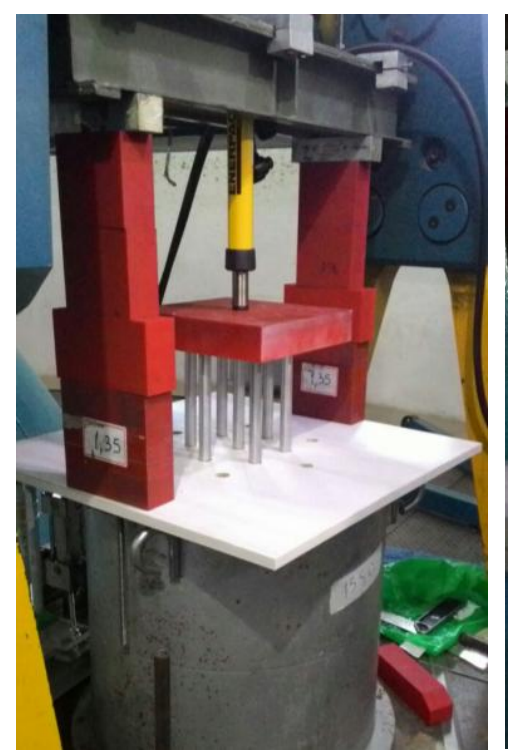

Figura 4.19: Processo de cravação das colunas metálicas. Ensaio com 7 colunas (à esquerda) e com 13 colunas (à direita).

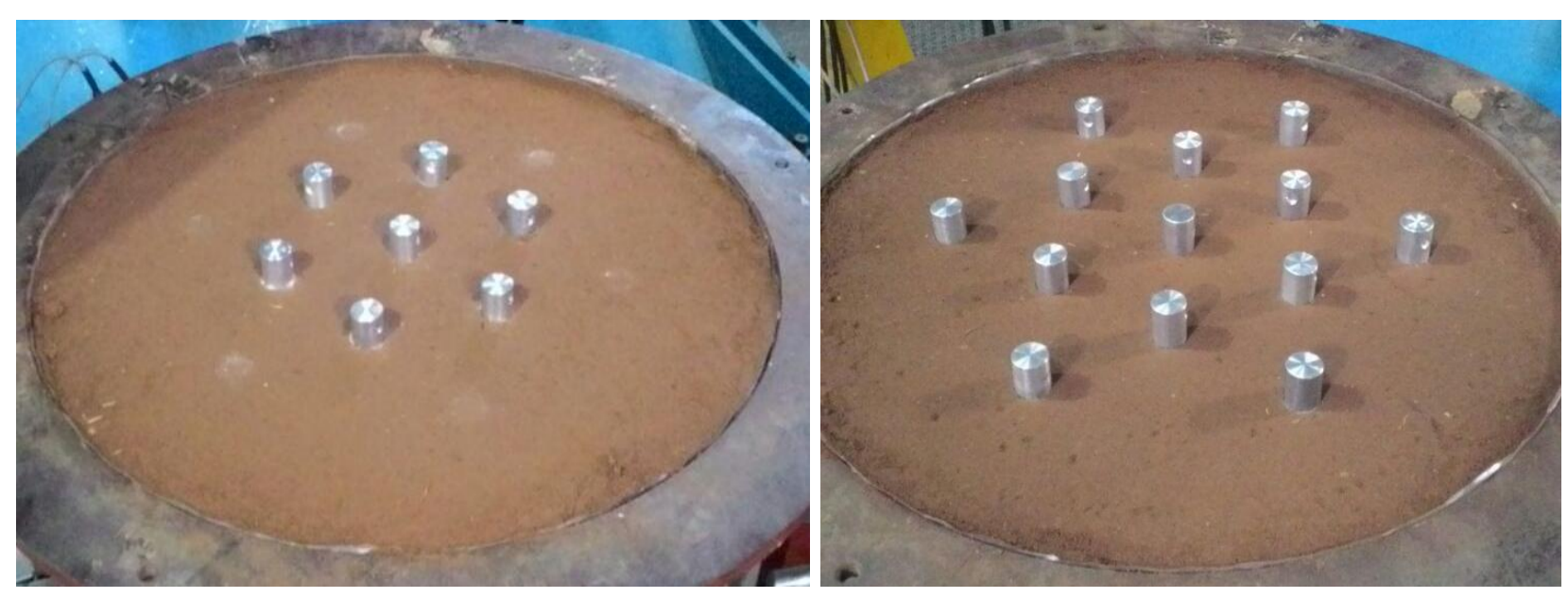

Figura 4.20: Colunas metálicas após término do processo de cravação. À esquerda, malha triangular com 7 colunas e, à direita, com 13 .

Terminada a cravação das colunas metálicas, era então retirado todo o sistema e a placa gabarito (com cuidado para não impactar a coluna metálica e danificar o solo). Posteriormente, as colunas metálicas eram retiradas uma a uma para início do processo de compactação, sempre do centro da malha em direção à sua periferia. Em todos os ensaios, os furos mantiveram-se estáveis e foi possível o processo de compactação de todas as colunas por controle de volume. 


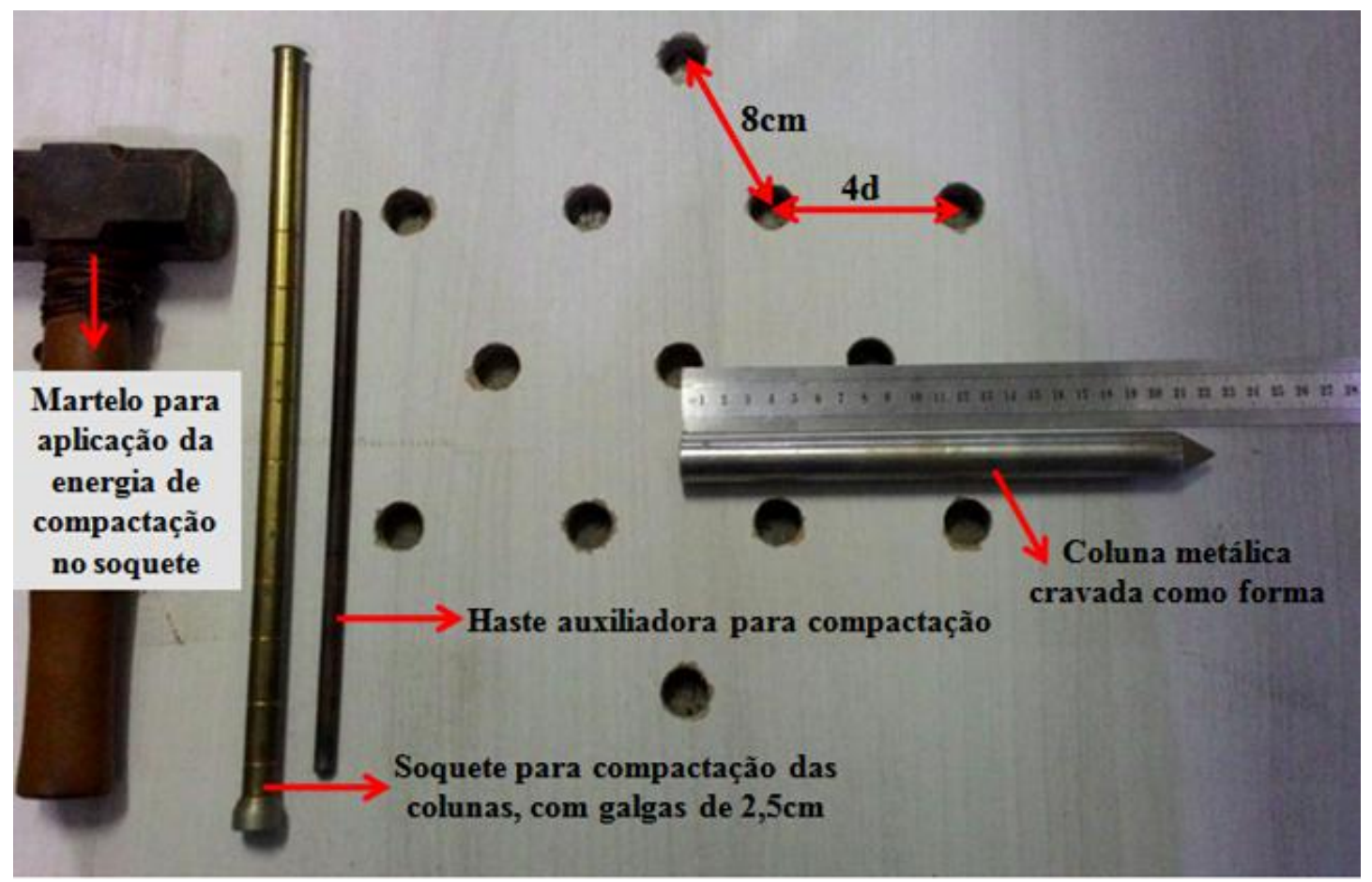

Figura 4.21: Placa gabarito utilizada para realização dos ensaios com malha triangular de espaçamento $4 d$ e materiais utilizados para compactação das colunas de solo laterítico.

Para as colunas, o processo de compactação também foi executado através do controle por volume. As galgas de $25 \mathrm{~mm}$ de altura no soquete compactador permitiam o cálculo aproximado do volume da coluna e da massa de solo necessária, nos parâmetros ótimos, para preenchimento do mesmo. O volume é dito aproximado porque foi embasado em experimentos anteriores tentando simular as mesmas condições (modelo físico não centrifugado) a partir dos quais, através da escarificação, obteve-se o aumento radial da coluna.

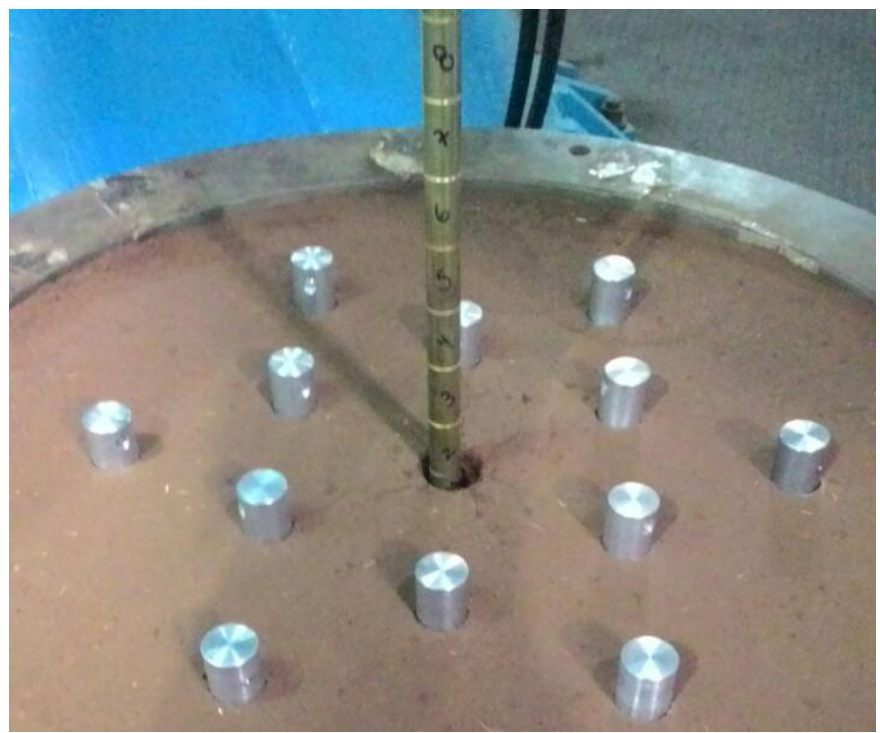

Figura 4.22: Soquete compactador galgado para compactação das colunas por controle de volume. Ao total, foram oito camadas de $25 \mathrm{~mm}$ de altura cada (conferindo os $200 \mathrm{~mm}$ de profundidade). 
Em uma das colunas, foi adicionado ao solo um pouco de caulim (argilomineral de cor branca, semelhante a um talco) para possibilitar, na escarificação do container, a noção da geometria da coluna de reforço.
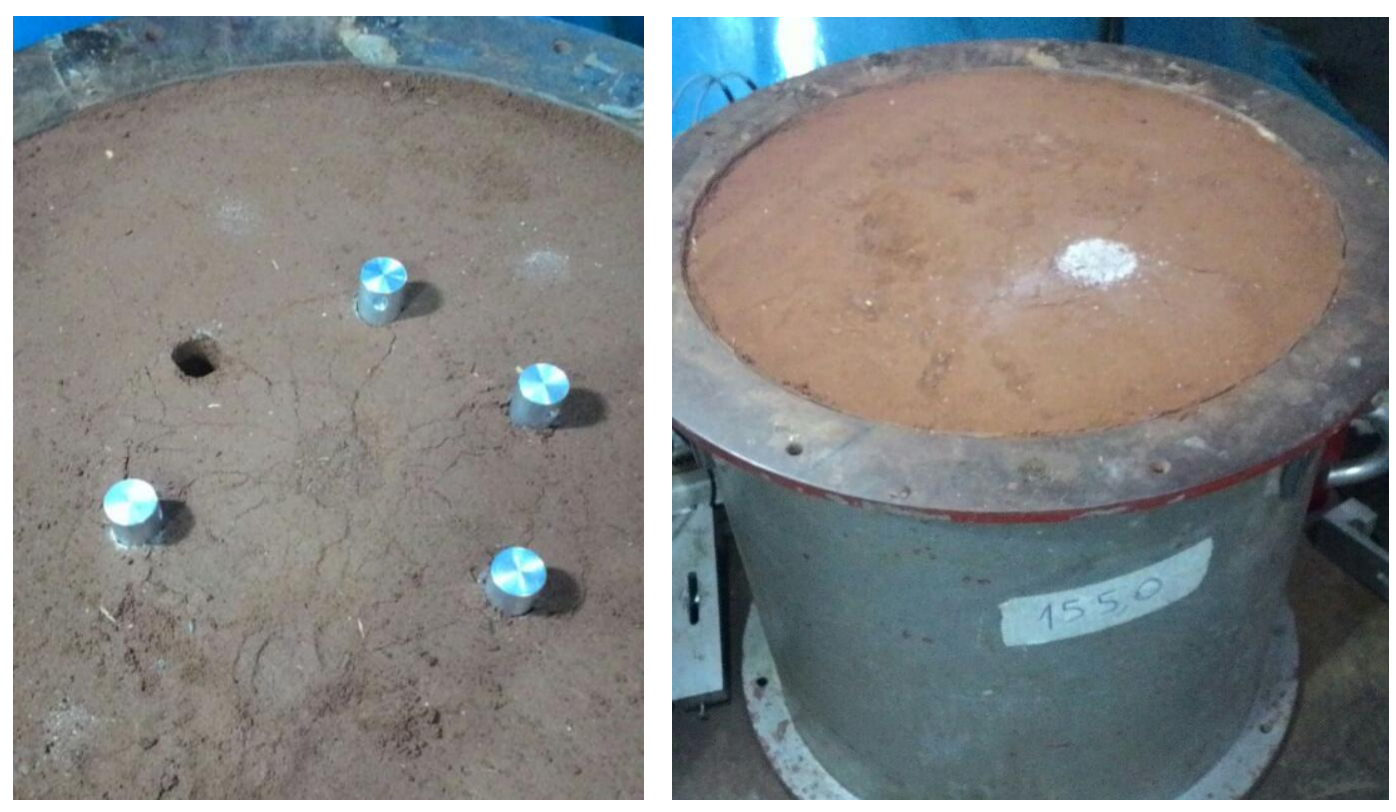

Figura 4.23: Compactação das colunas sendo executada uma a uma, do centro para a periferia da malha. Detalhe para a coluna com mistura de solo + caulim. Ensaio com 7 colunas.

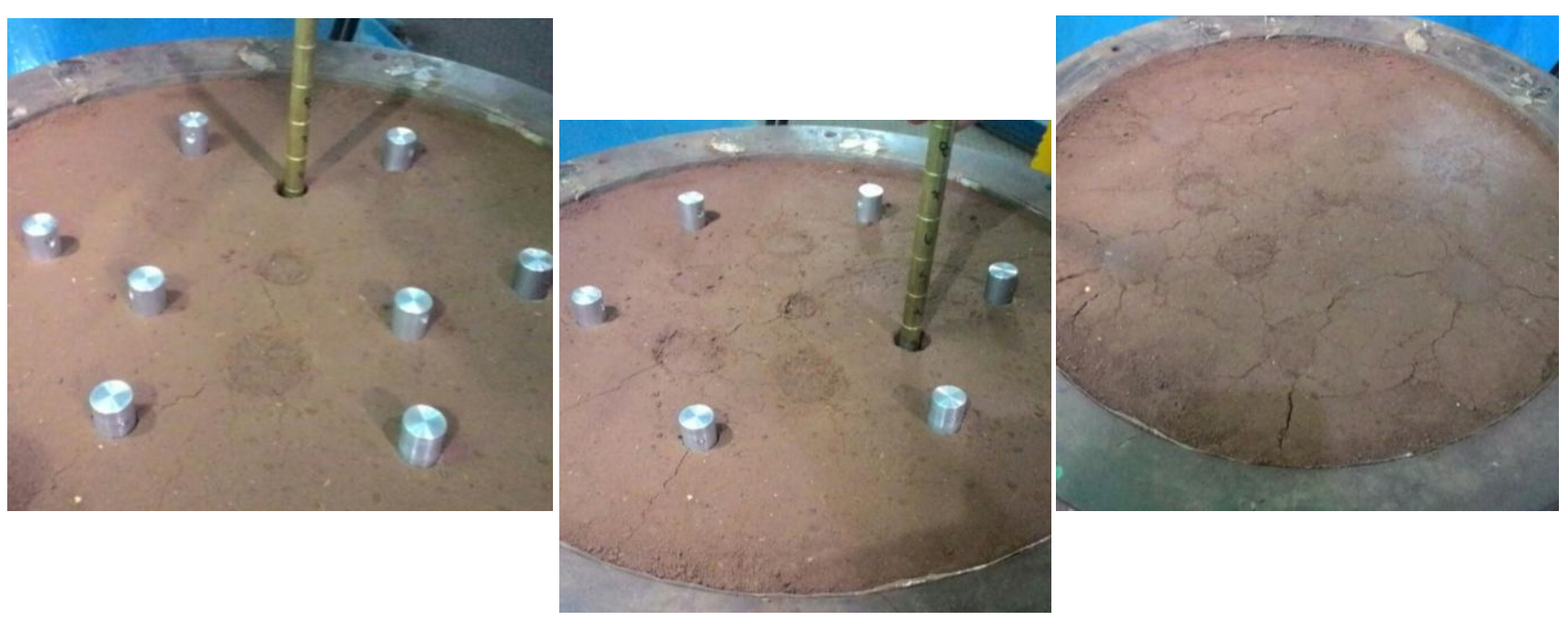

Figura 4.24: Processo de compactação da malha triangular com 13 colunas (imagens à esquerda e central) e container após todas as colunas terem sido compactadas (imagem à direita). 
As trincas presenciadas são oriundas dos processos de cravação e compactação. Como a compactação dava-se através do impacto do martelo no soquete e o solo encontrava-se confinado em sua base e lateral, as trincas surgiam na superfície devido à reestruturação provocada pelos processos de cravação e compactação.

\subsubsection{Malha de colunas com espaçamento 5d}

Foi testada também uma malha com espaçamento longitudinal entre os eixos das colunas de 5 vezes seu diâmetro $(5 d)$. Para esse caso, a malha triangular não seria viável, uma vez que a mesma teria parte de suas colunas fora da placa de atuação e parte dentro (provocando um efeito cisalhante). Assim sendo, optou-se pela malha quadrada, de espaçamento $5 d$, conforme ilustrado na Figura 4.25 abaixo. Para tal malha, foram testadas 4 colunas, todas sob a projeção da placa de atuação.

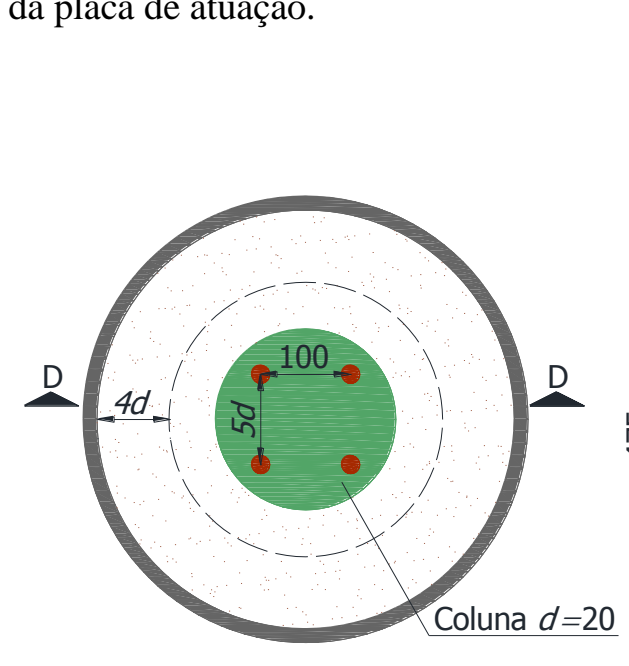

a)

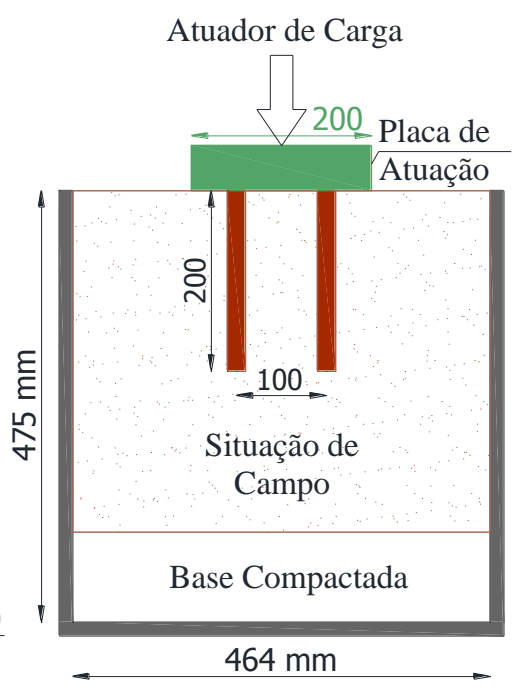

b)

Figura 4.25: Malha quadrada com 4 colunas, apenas na região de projeção da placa de atuação, com espaçamento entre eixos de $5 d$. Vista em planta (a) e em corte D-D (b). Medidas em milímetros.

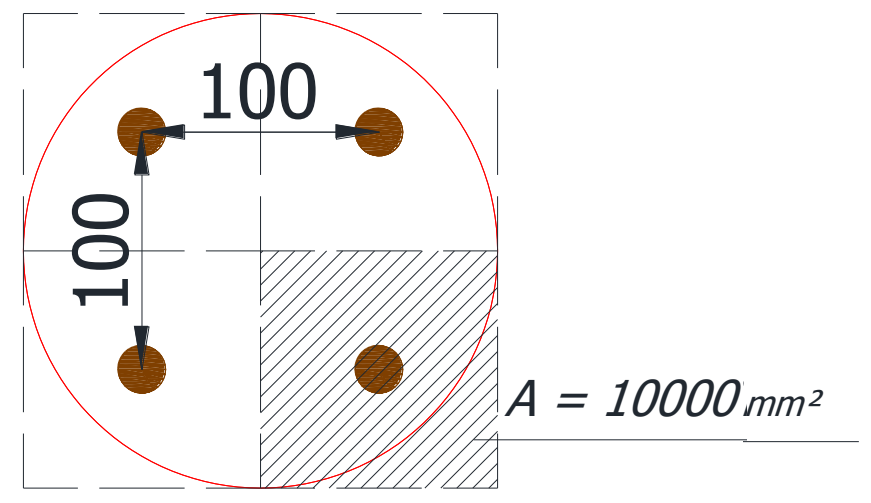

Figura 4.26: Ilustração da célula unitária quadrada. 
Para a malha apresentada, como visto, a célula unitária é também quadrada, com 100 mm de lado e taxa de cobertura $\alpha$ expressa por:

$$
\alpha(\%)=\frac{A_{p}}{A} \cdot 100=\frac{\left(\pi \cdot 20^{2} / 4\right)}{10000} \cdot 100=3,14 \%
$$

Uma nova placa gabarito foi utilizada para realização do ensaio com essa malha, ilustrada na Figura 4.27 a seguir.
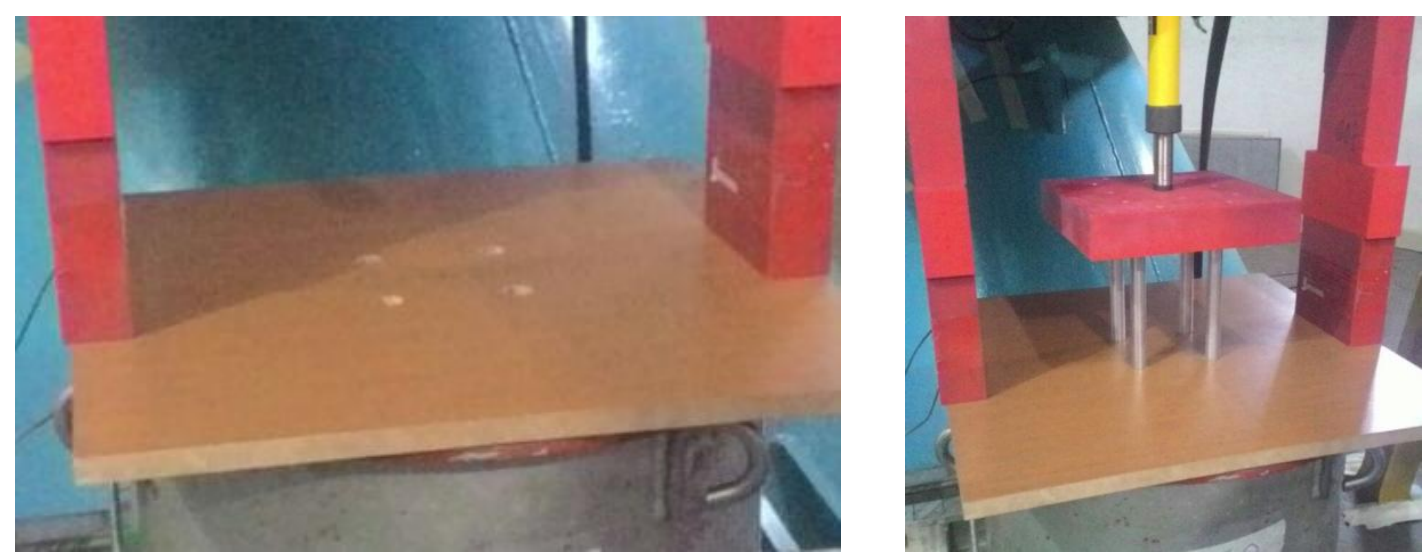

Figura 4.27: Placa gabarito para a malha quadrada (à esquerda) e cravação das quatro colunas metálicas (à direita).

O procedimento foi análogo ao da malha triangular, com retirada e compactação, uma a uma, de cada coluna individualmente.
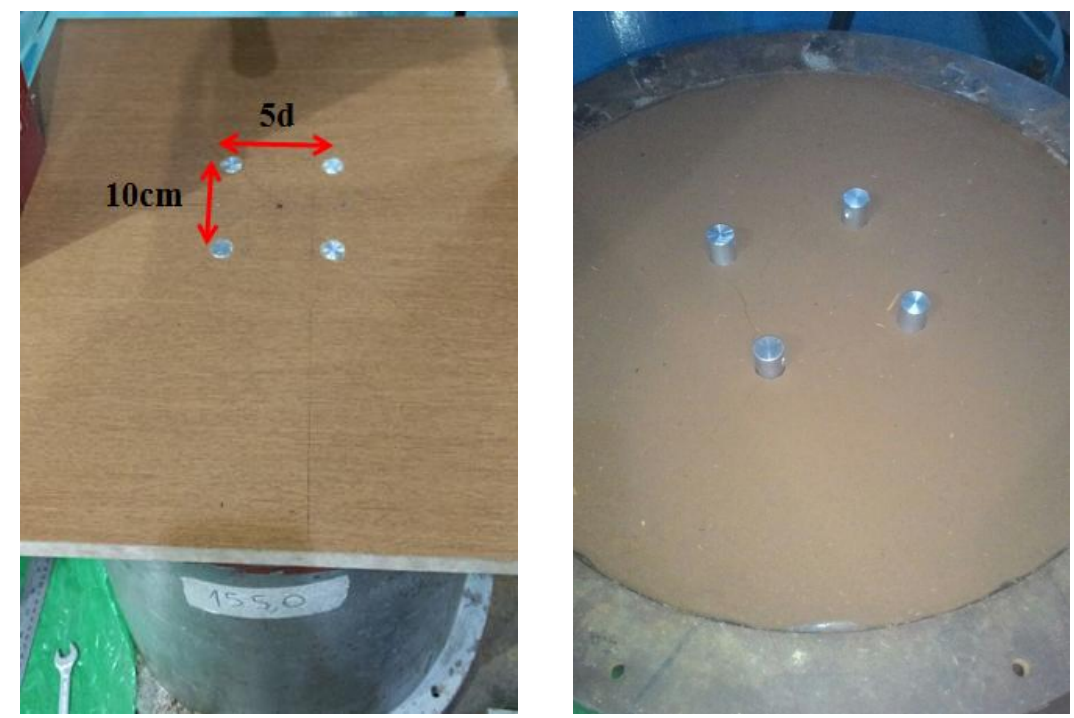

Figura 4.28: Colunas metálicas após término do processo de cravação. 

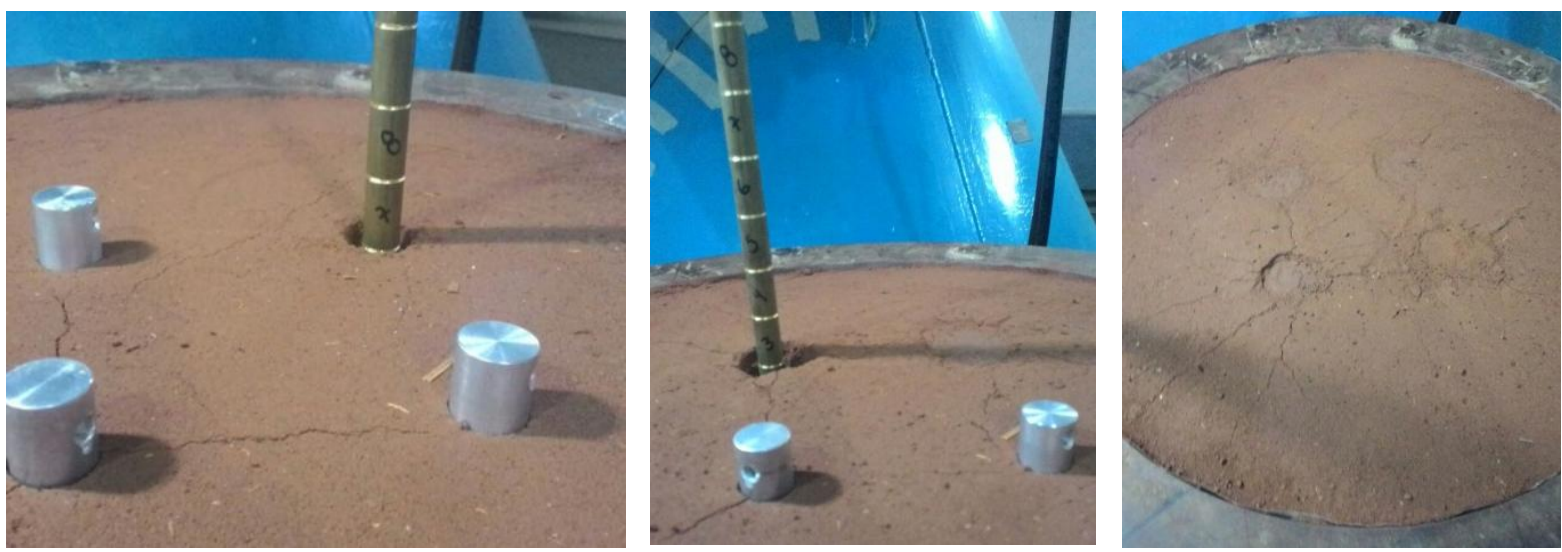

Figura 4.29: Processo de compactação das colunas de solo laterítico para a malha quadrada com 4 colunas.

Dessa forma, é possível sintetizar os ensaios realizados em um quadro para melhor entendimento, conforme é apresentado na Tabela 4.1 a seguir.

Tabela 4.1: Quadro de ensaios realizados na modelagem física em centrífuga geotécnica.

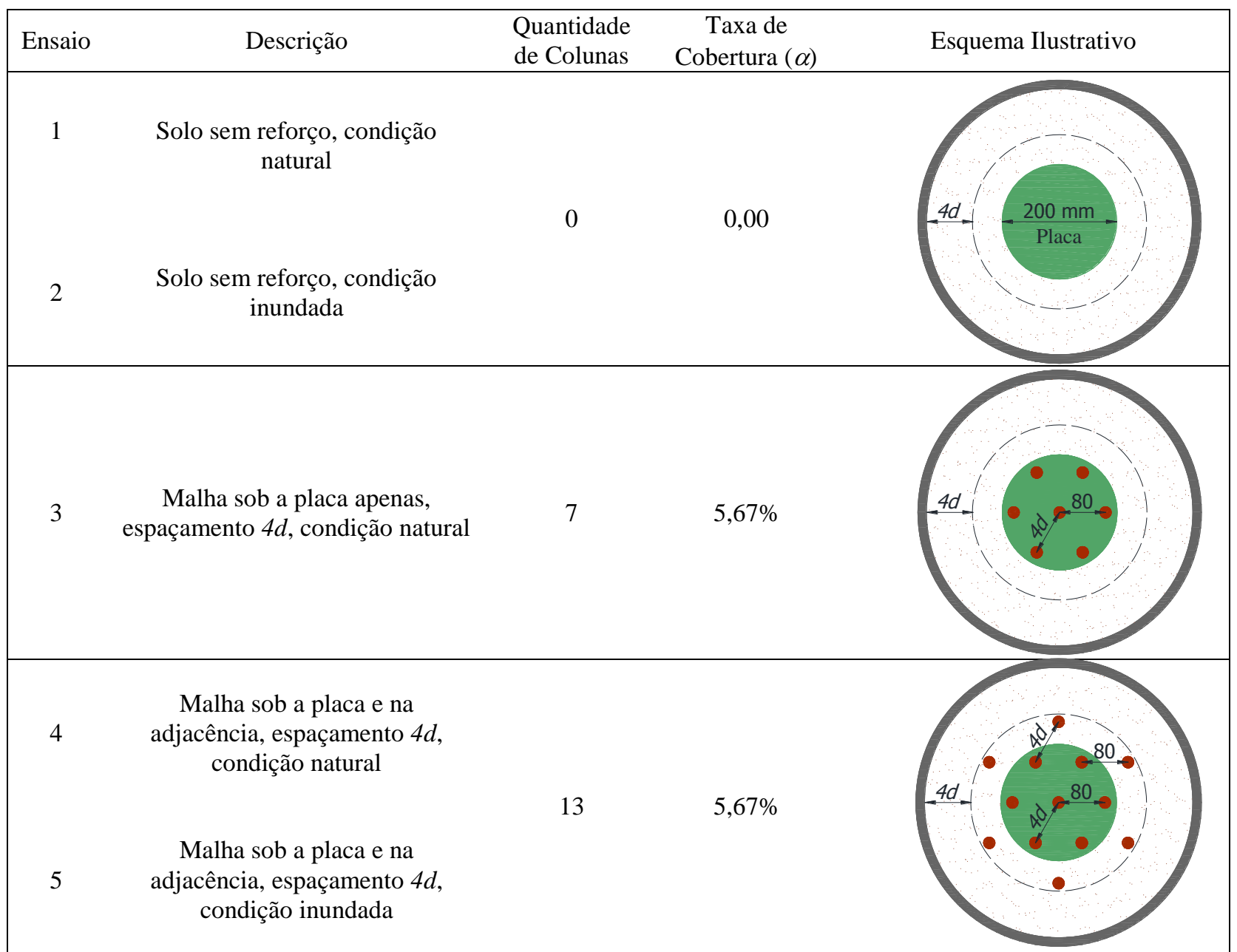




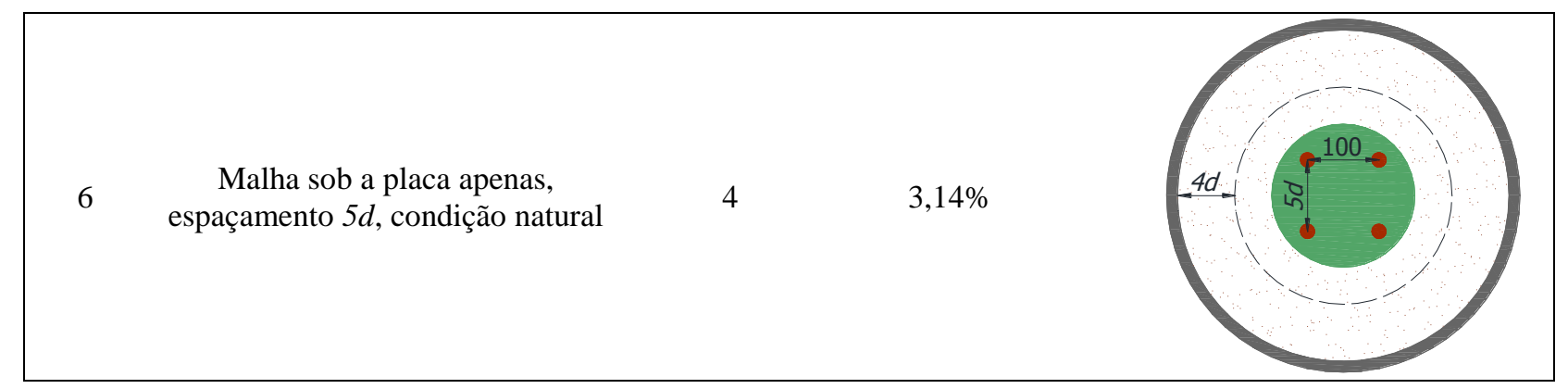

Vale ainda salientar que foram realizados apenas dois ensaios inundados pela limitação executiva encontrada. Foram preparados e transportados à centrífuga cerca de $400 \mathrm{~kg}$ de solo. Uma vez inundado (teor de umidade aumentado), não era possível a disposição do solo para secagem e realização de um novo ajuste do teor de umidade para reuso em outro ensaio. Assim sendo, o solo, após o ensaio inundado, era descartado. Como cada container necessitava de cerca de $150 \mathrm{~kg}$ de solo, a quantidade disponível era suficiente para apenas dois ensaios inundados.

Dessa foram, apenas os dois últimos ensaios realizados foram inundados e então o material retirado do container após ensaio foi descartado. Se não fosse essa limitação, seria amplamente indicada a realização dos ensaios inundados para todas as situações ensaiadas, visto que a problemática do solo em questão reside justamente em seu colapso devido à condição inundada.

Nos ensaios em que foi realizada a inundação, a mesma foi executada com o container parado $(1 g)$ devido à impossibilidade da inundação ser feita em voo. Assim sendo, calculou-se o volume de água necessário para praticamente saturar a camada central do solo ao longo de toda a profundidade das colunas de reforço e ainda um pouco abaixo (cerca de 6 camadas de profundidade no total).

Para o ensaio do solo sem reforço, a inundação deu-se desde o início do ensaio, simulando um ensaio edométrico duplo (onde foi ensaiado um container sem reforço não inundado e um container sem reforço inundado desde o início). Dessa forma, a última camada do container (camada de número 10, com $25 \mathrm{~mm}$ de altura) não foi preenchida, para possibilitar formar uma lâmina d'água durante a inundação sem haver transbordamento. 

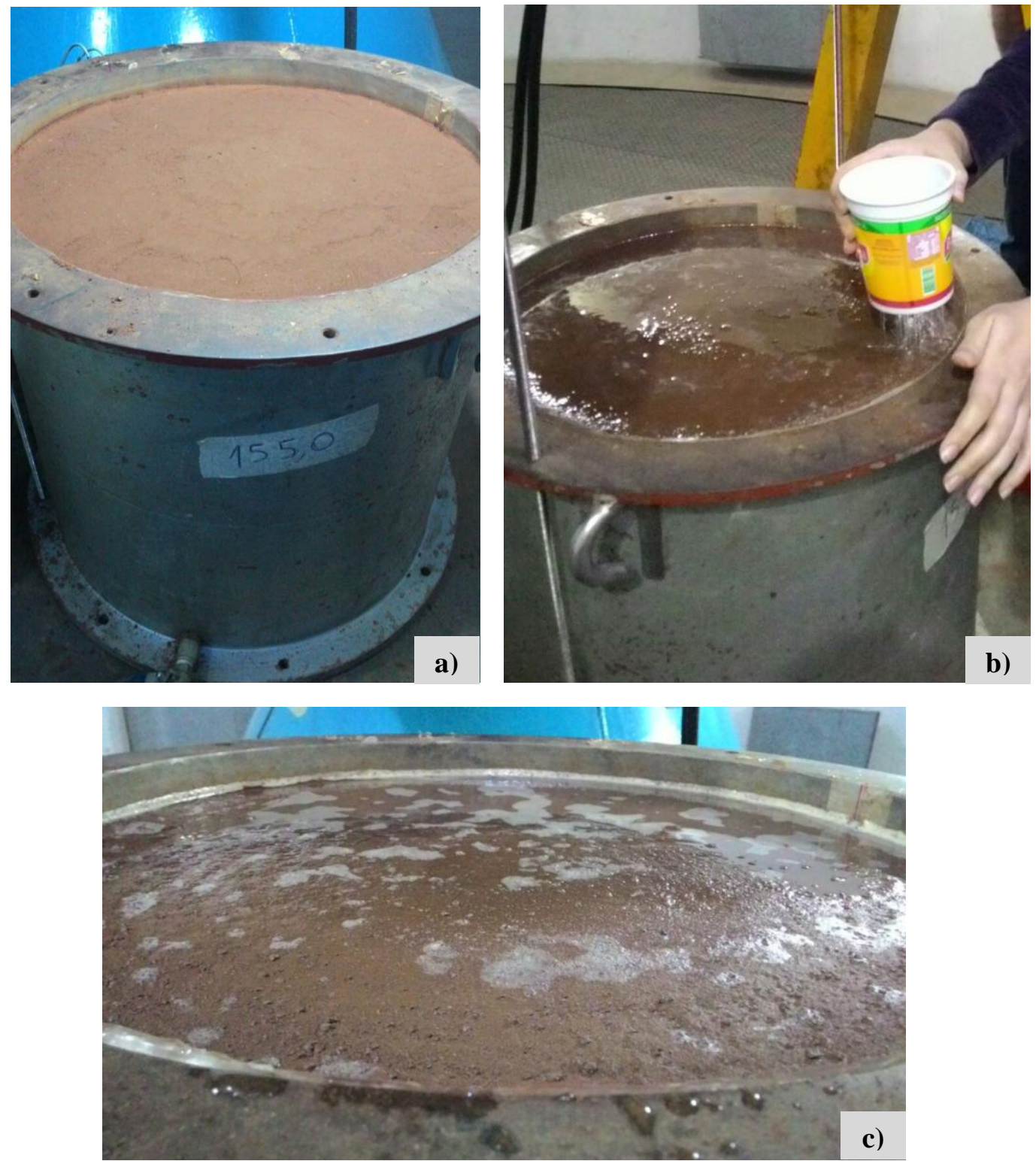

Figura 4.30: Container sem reforço preenchido até a camada número 9 (a), container sendo inundado gradativamente (b) e container após a inundação pronto para início do voo.

Para o ensaio do solo reforçado com 13 colunas (malha triangular, espaçamento 4d), o ensaio foi executado normalmente na condição não inundada e, após seu término, realizou-se a inundação do container e então procedeu-se o voo pela segunda vez para o mesmo ensaio. 


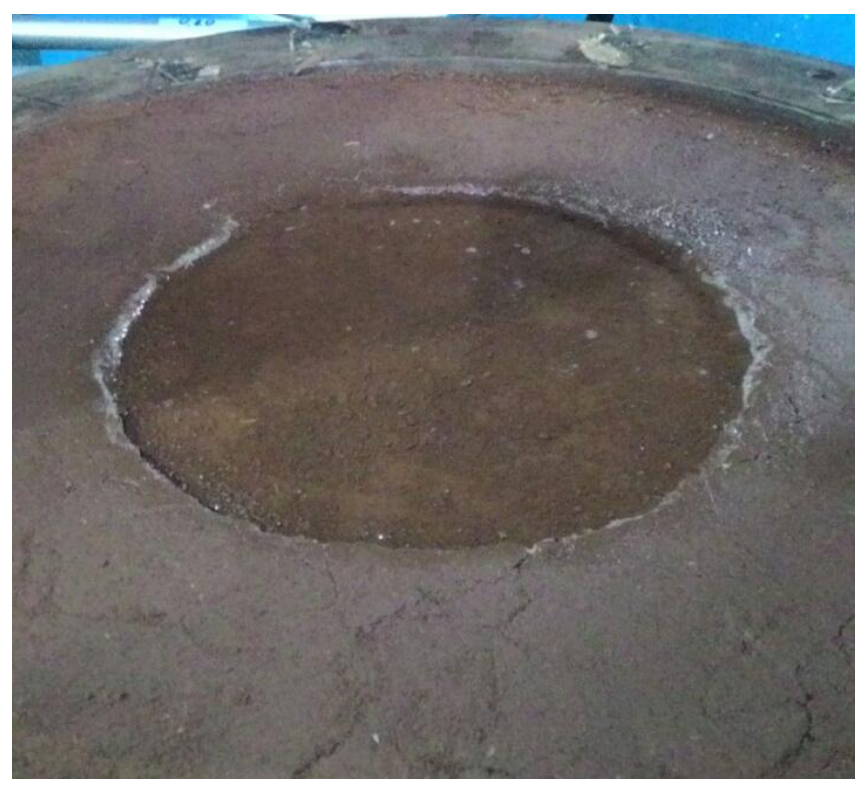

Figura 4.31: Ensaio com 13 estacas inundado, após realização do primeiro voo (na condição não inundada).

Aproveitou-se o deslocamento causado pela placa de atuação no primeiro ensaio não inundado para realizar a inundação e formar uma lâmina de água nas colunas centrais abaixo da placa (conforme ilustrado na Figura 4.31).

Quanto à instrumentação do ensaio, o limite de curso do pistão para medidas de deslocamento vertical era de aproximadamente $60 \mathrm{~mm}$. A velocidade média de atuação foi equivalente a 0,15 milímetros por segundo. Para o ensaio sem reforço inundado, foi utilizada a célula de carga com capacidade de $1.000 \mathrm{lbf}(4.500 \mathrm{~N})$, pois sabia-se que não seria atingida essa carga antes do limite de curso do pistão ser completado. Além disso, a célula de carga de 1.000 lbf tinha uma precisão melhor nas leituras. Para todos os demais ensaios, utilizou-se a célula de carga com capacidade de $3.000 \mathrm{lbf}(13.500 \mathrm{~N})$. Dessa forma, os ensaios eram sempre limitados ou pela capacidade da célula de carga ou então pelo limite de curso do pistão.

\subsection{Modelagem Numérica}

A parte de modelagem numérica do presente trabalho é referente tanto ao resultado experimental obtido pelo estudo em campo de Freitas (2016) quanto aos resultados da modelagem física em centrífuga realizada no presente estudo. Como a modelagem em 
centrífuga foi constituída do reforço através de malhas, seria viável a realização da modelagem em três dimensões, para melhor entendimento do ocorrido. Contudo, o software inicialmente cogitado para realização da modelagem numérica (o Abaqus) apresenta a forte limitação de não apresentar modelos constitutivos específicos para solos. O que ele apresenta é um código geral, relacionado a problemas mecânicos, sendo mais satisfatoriamente utilizado para descrever materiais de comportamento elástico linear (como concreto e aço, por exemplo).

Por conta dessa limitação, optou-se pela realização da modelagem em Plaxis 8.2 que, mesmo impossibilitando uma análise tridimensional, apresenta melhores modelos constitutivos próprios para materiais geotécnicos.

Os tipos de modelagem possíveis nesse software são: o Plane Strain e o Axissimétrico. O primeiro consiste em um plano $x, y$ de profundidade unitária (indicado para barragens, muros de arrimo e entre outros). Já o modelo axissimétrico consiste em um eixo longitudinal de simetria e considera "fatias representativas", de ângulo equivalente a um radiano (sendo mais indicado para estacas e colunas). O software ainda confere a possibilidade de fazer a análise com elementos de 15 nós (15 pontos de interpolação) ou 6 nós (6 pontos de interpolação), sendo a primeira mais detalhada.

\subsubsection{Modelagem de Coluna Experimental}

Primeiramente, houve a realização de um modelo numérico simulando a prova de carga executada em campo com as colunas experimentais de Freitas (2016). Para isso, foi utilizado um modelo axissimétrico, com 15 nós. Foi considerado, inicialmente, um maciço de $10 \mathrm{~m}$ de profundidade (5 vezes a profundidade da coluna) por 4 metros de largura. Todavia, verificou-se que as tensões não influenciavam em grandes profundidades e, para otimizar a modelagem, reduziu-se a geometria para um maciço de 5 metros de profundidade por 4 metros de largura.

O pilão utilizado em campo foi o de ponta cilíndrica com diâmetro de 216 milímetros. A profundidade considerada do furo apiloado foi equivalente a 2,0 metros. Pelos resultados ilustrados na Tabela 3.6, para o pilão de ponta cilíndrica, houve um acréscimo de $23 \%$ no diâmetro e de 5,6\% na profundidade. Dessa forma, foi considerado, no modelo, a coluna com um diâmetro de 266 milímetros e uma profundidade final de 2,20 metros (prevendo a descida do material compactado pela queda do pilão). 
A geometria da coluna considerada foi retangular, visto que para o pilão cilíndrico há uma uniformidade no aumento radial ao longo da profundidade (Figura 3.8). Além disso, o maciço foi dividido em diferentes regiões tal que fosse simulada a melhoria do solo de acordo com as amostras indeformadas retiradas para cálculo dos índices físicos. A geometria com as diferentes regiões consideradas encontram-se ilustradas na Figura 4.32 abaixo.
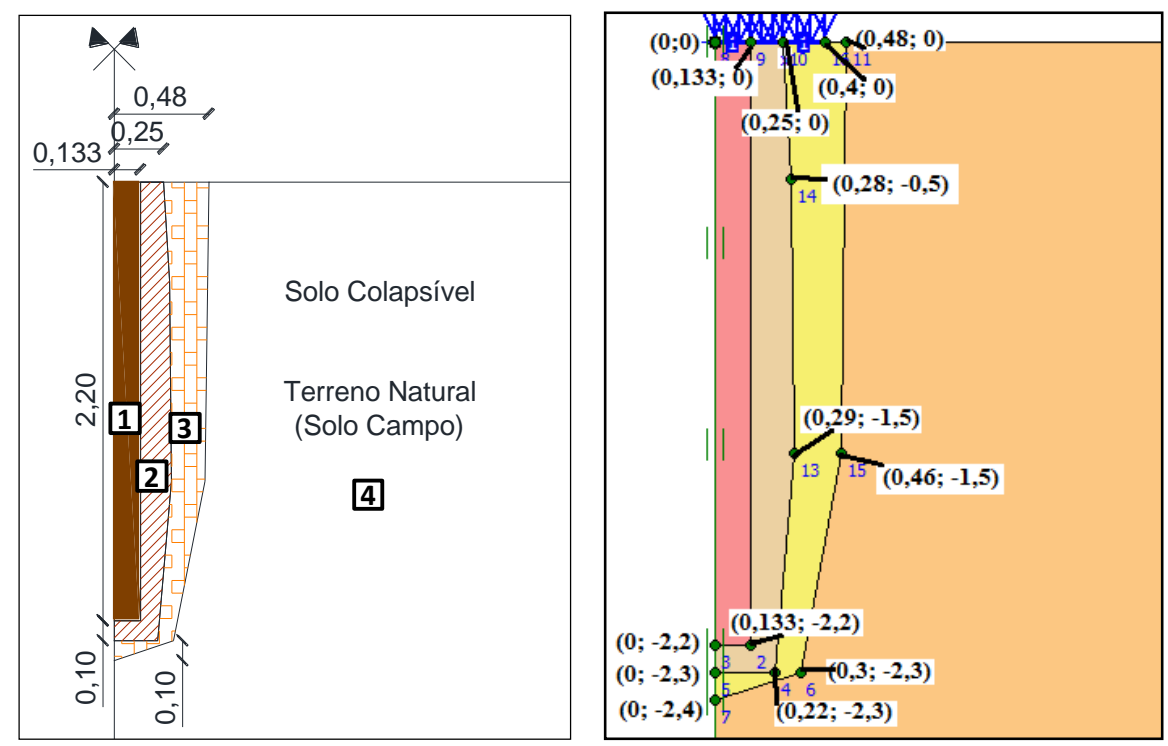

Figura 4.32: Geometria considerada a partir do eixo de simetria do modelo axissimétrico, com as diferentes regiões estabelecidas. Medidas em metros.

Para cada região de solo delimitada, criou-se um material em específico, com parâmetros variados. Como não foi realizado nenhum ensaio de laboratório para obtenção dos parâmetros de resistência, todos os valores de ângulo de atrito $(\phi)$ e coesão $(c)$ foram arbitrados tal que melhor se ajustassem ao resultado desejado (curva tensão $x$ deslocamento experimental).

Os únicos parâmetros de antemão conhecidos eram os referentes ao módulo de deformabilidade equivalente da coluna de solo compactado e do solo natural sem reforço (maciço natural), às massas específicas secas e aos teores de umidade de cada amostra indeformada retirada em diferentes distâncias do centro da coluna. A partir da Tabela 3.4 foram calculados os valores dos pesos específicos de cada região definida na geometria, conforme ilustrado na Tabela 4.2 a seguir. $\mathrm{O}$ valor adotado para o peso específico da água foi referente a $10 \mathrm{kN} / \mathrm{m}^{3}$. 
Tabela 4.2: Pesos específicos considerados para as diferentes regiões.

\begin{tabular}{|ccccc|}
\hline Distância $(\mathbf{c m})$ & $\boldsymbol{\rho d}\left(\mathbf{g} / \mathbf{c m}^{3}\right)$ & $w(\%)$ & $\rho\left(\mathbf{g} / \mathbf{c m}^{3}\right)$ & $\gamma\left(\mathbf{k N} / \mathbf{m}^{3}\right)$ \\
\hline 0 & 1,85 & 14,60 & 2,12 & 21,20 \\
25 & 1,99 & 14,90 & 2,29 & 22,87 \\
45 & 1,67 & 17,40 & 1,96 & 19,61 \\
\hline
\end{tabular}

Não são encontrados, na literatura, os parâmetros de resistência do solo pertencente ao campo experimental quando compactado nos parâmetros ótimos. Alguns estudos realizados que envolveram ensaios triaxiais, contudo, apontam que os parâmetros para o solo natural encontram-se em torno de $29^{\circ}$ para o ângulo de atrito efetivo e $0 \mathrm{kPa}$ para a coesão (pior situação, quando a sucção matricial é próxima de zero). Para o coeficiente de Poisson, foi adotado um valor típico da literatura para solos arenosos entre 0,30 e 0,35.

Como os módulos de deformabilidade de Freitas (2016) foram calculados por uma retroanálise dos resultados da prova de carga pelo método de Schmertmann (1978), considerando um valor constante para o bulbo de tensões da placa de ensaio (o que na prática não ocorre de fato), o módulo equivalente foi considerado como uma média e os módulos de deformabilidade adotados para os diferentes materiais foram embasados na mesma, sendo inversamente proporcionais à distância do centro da coluna de reforço. Além disso, todos os parâmetros de resistência (ângulo de atrito $\phi$ e coesão $c$ ) para as diferentes regiões foram arbitrados tal que o modelo melhor de ajustasse à curva experimental (sempre fidedigno, contudo, à realidade apresentada em campo).

Para simular o ensaio de prova de carga estática realizada, inseriu-se um elemento "Plate" com as dimensões da placa ensaiada e distribuiu-se o carregamento em toda sua extensão. O módulo de deformabilidade $E$ considerado foi de $200 \mathrm{GPa}$, referente ao aço. A espessura $d$ foi obtida através da massa do elemento fornecida $(150 \mathrm{~kg})$. Sendo o peso específico considerado equivalente a $70 \mathrm{kN} / \mathrm{m}^{3}$, para que o peso próprio resultasse em $1500 \mathrm{~N}$ (peso da placa), seria, portanto, necessário um volume de $0,0214 \mathrm{~m}^{3}$. Ou seja:

$$
\begin{gathered}
\text { Peso }=m \cdot g=150 \mathrm{~kg} \cdot 10 \mathrm{~m}^{2} / \mathrm{s}=1500 \mathrm{~N}=1,5 \mathrm{kN} \\
\text { Volume }=\frac{\text { peso }}{\gamma}=\frac{1,5}{70}=0,0214 \mathrm{~m}^{3}
\end{gathered}
$$

Tendo a placa 80 centímetros de diâmetro, sua área equivale, portanto, a:

$$
A=\frac{\pi \cdot d^{2}}{4}=\frac{\pi \cdot 0,80^{2}}{4}=0,50 \mathrm{~m}^{2}
$$


Considerando a placa como um corpo rígido cilíndrico, seu volume é dado por:

$$
V=A . h \rightarrow 0,0214=0,50 . h \rightarrow h=0,0428
$$

Dessa forma, tem-se que a espessura equivalente da placa a ser considerada no modelo refere-se a $0,0428 \mathrm{~m}$.

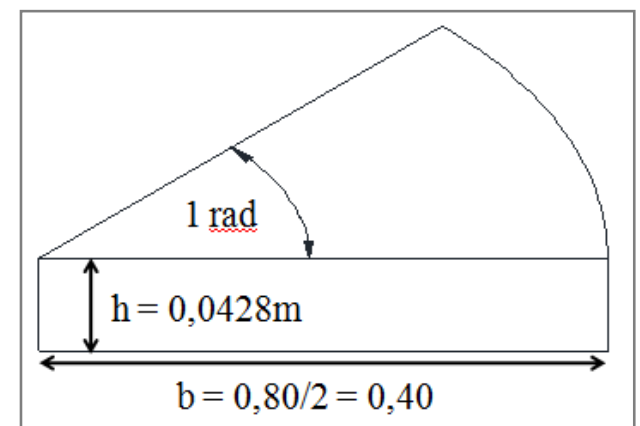

Figura 4.33: Esquema representativo do modelo axissimétrico da placa considerada.

Considerando um modelo elástico para o material "plate" adicionado, são necessários alguns parâmetros de entrada, conforme detalhado a seguir.

$$
\begin{gathered}
E A=200.000 .000 \times 0,4 \times 0,0428=3.424 .000 \mathrm{kN} / \mathrm{m} \\
E I=200.000 .000 \times\left(\frac{0,40 \times 0,0428^{3}}{12}\right)=522,7 \mathrm{kN} \cdot \mathrm{m}^{2} / \mathrm{m}
\end{gathered}
$$

Para os diferentes materiais geotécnicos, foram inseridos os parâmetros de acordo com os dados disponíveis e também com os arbitrados. A curva experimental escolhida para ser modelada refere-se ao ensaio inundado. Isso porque durante a realização dos ensaios de prova de carga, o período era muito chuvoso (explicando a similaridade entre as curvas inundada e não inundada). Além disso, julga-se que houve um deslocamento do equipamento no início do ensaio da prova de carga não inundada, explicando os maiores deslocamentos iniciais desse ensaio e a similaridade entre a forma de ambas as curvas (inundada e não inundada). Por essas razões, a curva modelada será a referente ao ensaio inundado, considerado como melhor representativo do ocorrido em campo.

Dessa forma, os dados são referente à Coluna de Solo Compactado 1 (solo inundado), com um módulo de deformabilidade equivalente de $27.330 \mathrm{kPa}$. Para o solo do campo (sem reforço), o módulo de deformabilidade equivale a $8.540 \mathrm{kPa}$ (Tabela 3.5). O nível d'água é inexistente no modelo (não havendo, portanto, poropressões). 


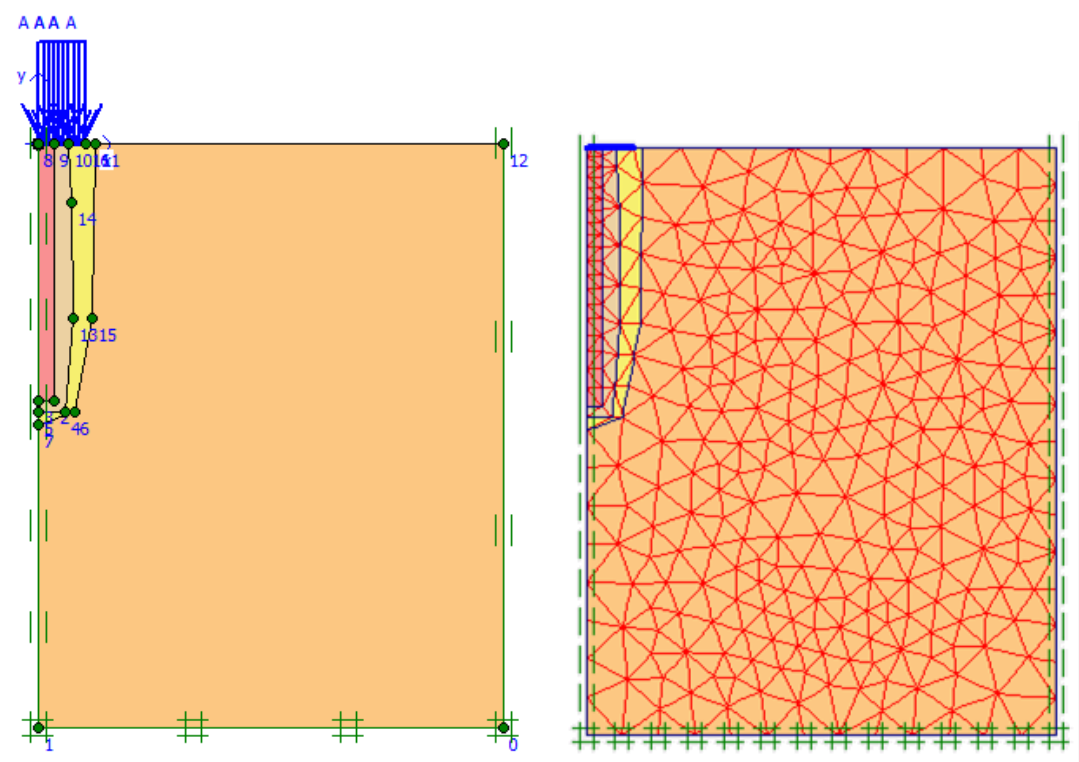

Figura 4.34: Geometria definida com os materiais e carregamento já atribuídos (à esquerda) e geração da malha de elementos finitos (à direita).

\subsubsection{Modelagem dos Ensaios em Centrífuga Geotécnica}

Para realização dessa modelagem, também foi considerado o modelo axissimétrico, com 15 pontos de interpolação (15 nós) e o modelo constitutivo de Mohr-Coulomb para todos os materiais geotécnicos. Foi modelado o protótipo (em escala real, 10 vezes a do modelo em centrífuga), sendo que, tanto para o solo sem reforço quanto para os solos reforçados, foi arbitrado um módulo de deformabilidade equivalente tal que fosse obtido um resultado similar ao apresentado nos ensaios em centrífuga geotécnica.

\subsubsection{Solo sem Reforço}

Para o solo sem reforço, realizou-se a modelagem sem nível d'água para comparação com o ensaio não inundado. Os materiais geotécnicos constituintes (além do similar ao container e à placa de atuação) foram dois: o referente ao solo natural (simulando as condições de campo, com grau de compactação de $75 \%$ e teor de umidade de $10,5 \%$ ) e à base compactada com grau de compactação de $100 \%$ e 1 metro (100 mm ou 2 camadas, no modelo) de altura. Para o container e placa de atuação, foram inseridos materiais "plates" (comportamento linear), cujos parâmetros foram calculados analogamente ao discorrido no item 4.4.1 do presente trabalho. 


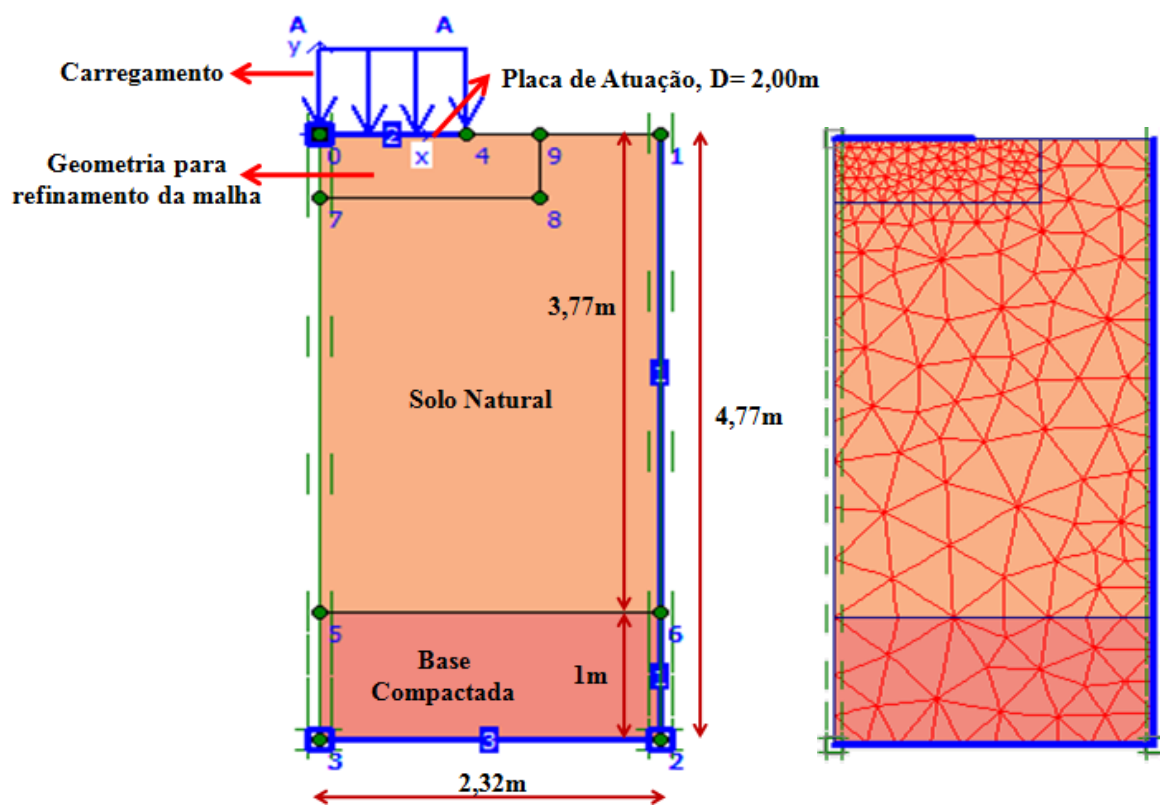

Figura 4.35: Geometria utilizada para simular o protótipo ensaiado (à esquerda) e malha de elementos finitos (à direita) em software para modelagem numérica, referente ao solo sem reforço.

\subsubsection{Malha de colunas com espaçamento 4d}

Para o solo reforçado com a malha triangular de espaçamento $4 d$, inclui-se um terceiro material geotécnico referente ao solo reforçado com um módulo de deformabilidade equivalente tal que fosse gerada a curva carga versus deslocamento a ser comparada com o resultado do ensaio em centrífuga geotécnica.
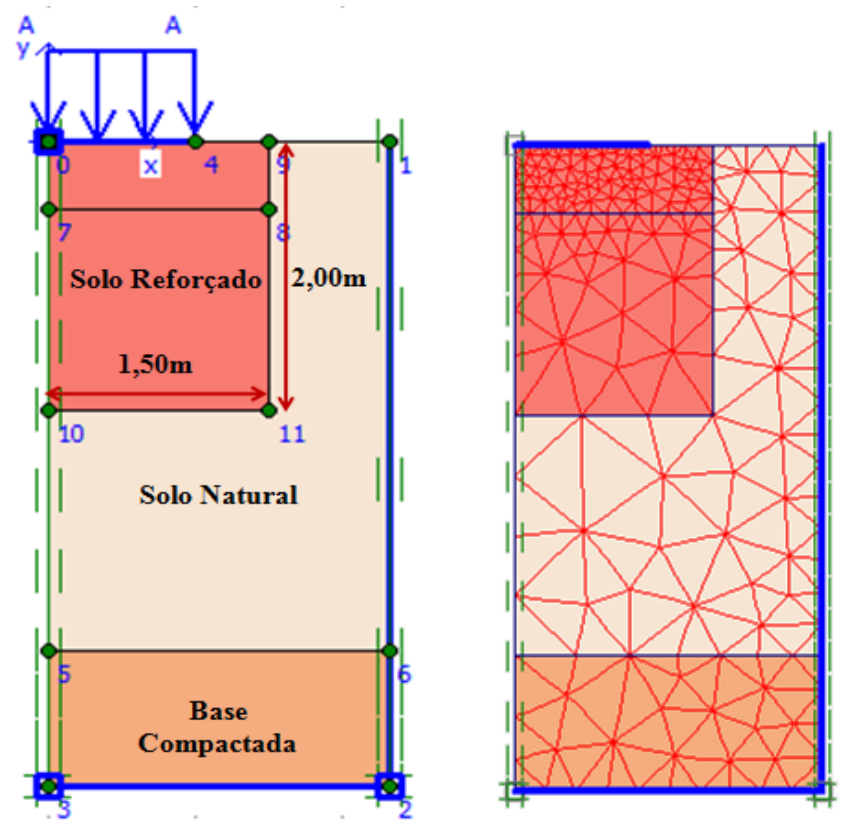

Figura 4.36: Geometria referente ao protótipo (à esquerda) e malha de elementos finitos (à direita) para o solo reforçado com uma malha triangular de colunas com espaçamento $4 d$. 


\subsubsection{Malha de colunas com espaçamento $5 d$}

Para a malha quadrada de espaçamento $5 d$, o conceito utilizado foi o mesmo (módulo de deformabilidade equivalente para o solo reforçado). Contudo, o volume de solo reforçado foi bem menor quando comparado ao reforço com a malha triangular de espaçamento $4 d$, visto que além do espaçamento ser maior, a quantidade de colunas utilizadas no reforço era menor, reforçando menos a camada de solo colapsível.
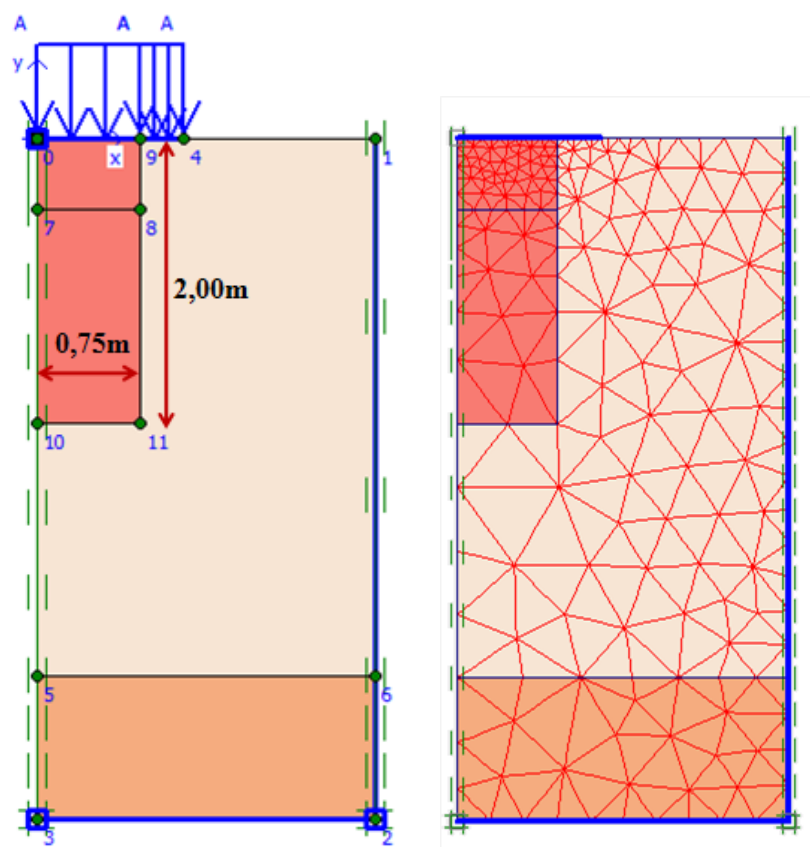

Figura 4.37: Geometria utilizada para simular o protótipo reforçado com a malha quadrada de espaçamento $5 d$ (à esquerda) e geração da malha de elementos finitos (à direita). 


\subsection{Ensaios de Laboratório}

\subsubsection{Ensaios de Caracterização}

\subsubsection{Massa Específica dos Sólidos}

Para a massa específica dos sólidos $\left(\rho_{S}\right)$, realizada de acordo com as diretrizes da norma ABNT NBR 6508/1984, encontrou-se como resultado um valor de 2,656 g/ $\mathrm{cm}^{3}$ para o solo estudado.

\subsubsection{Análise Granulométrica Conjunta}

Para a análise da granulometria, foram realizadas as etapas de sedimentação e peneiramento. A curva granulométrica obtida é expressa na Figura 5.1 abaixo.

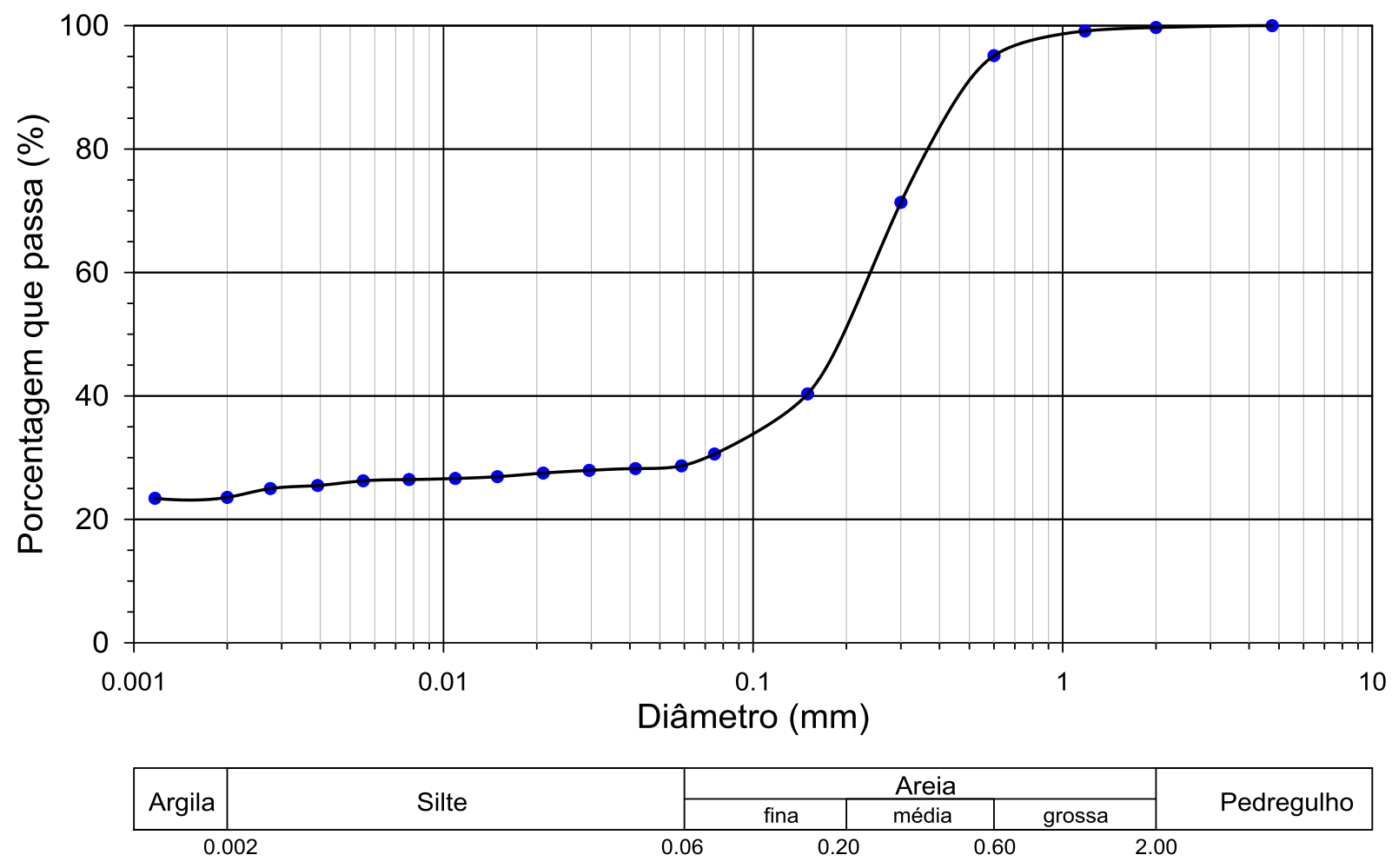

Figura 5.1: Resultado da curva granulométrica obtida do ensaio de análise granulométrica conjunta. 
Através da análise da curva granulométrica, pode-se concluir que o solo é composto de $23 \%$ de argila, $6 \%$ de silte e $71 \%$ de areia (sendo $23 \%$ areia fina, $43 \%$ de areia média e $5 \%$ de areia grossa). O solo estudado pode ser classificado, portanto, como uma areia média a fina argilosa marrom avermelhada.

\subsubsection{Limites de Atterberg}

Ainda para a caracterização do solo estudado, foram realizados os ensaios de limite de plasticidade e limite de liquidez, conforme ilustrado na Figura 5.2 a seguir. Para a determinação do limite de liquidez, utilizou-se o procedimento de ensaio através do aparelho de Casagrande, cujo gráfico de fluência calculado em escala mono-logarítmica é expresso na Figura 5.3 abaixo.
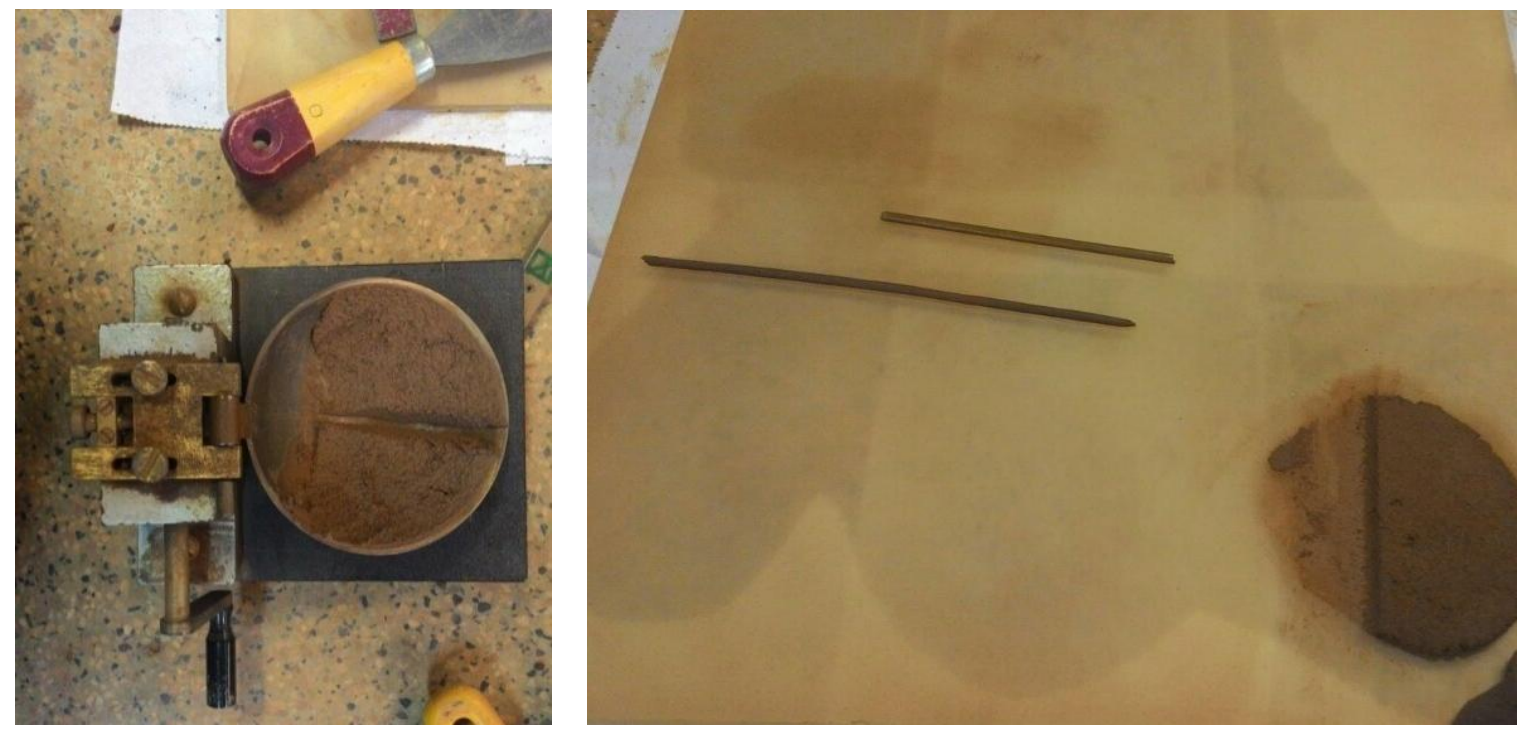

Figura 5.2: Execução dos ensaios de limite de liquidez (à esquerda) e de plasticidade (à direita).

Para o limite de plasticidade $(L P)$ obteve-se, como resultado, o valor de $16 \%$. O limite de liquidez $(L L)$ foi calculado conforme o ajuste dos pontos obtidos no aparelho de Casagrande, conforme ilustrado a seguir. 


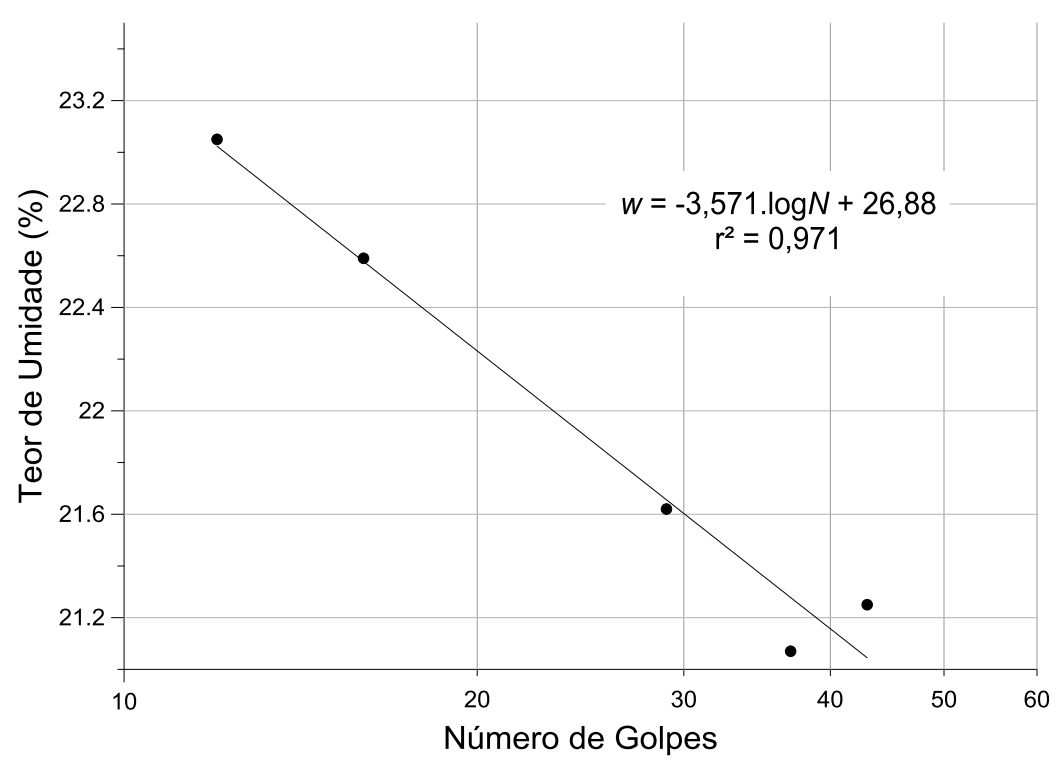

Figura 5.3: Gráfico de fluência obtido através do ensaio de limite de liquidez.

Para um valor $\mathrm{N}$ equivalente a 25 golpes, é então obtido o valor de $22 \%$ de limite de liquidez, conferindo, portanto, um Índice de Plasticidade $(I P)$ expresso por:

$$
I P=L L-L P=22-16=6
$$

\subsubsection{Ensaio de Compactação}

Determinada a umidade higroscópica da amostra a ser ensaiada, foi possível o cálculo da quantidade de água necessária para que o teor de umidade do corpo de prova a ser compactado aproximasse-se de alguns pontos previamente escolhidos tal que fosse possível um traçado satisfatório da curva de compactação. Dessa forma, foram preparadas sete amostras para compactação com teores de umidade de $8,5 \% ; 10,0 \% ; 11,5 \% ; 13,0 \% ; 14,5 \%, 16,0 \%$ e $17,5 \%$.

Os resultados encontram-se ilustrados na Figura 5.4 abaixo, a partir da qual foram determinados os parâmetros ótimos de compactação como sendo equivalentes a uma massa específica seca máxima de $1,88 \mathrm{~g} / \mathrm{cm}^{3}$ e um teor de umidade ótimo de 13,5\%. 


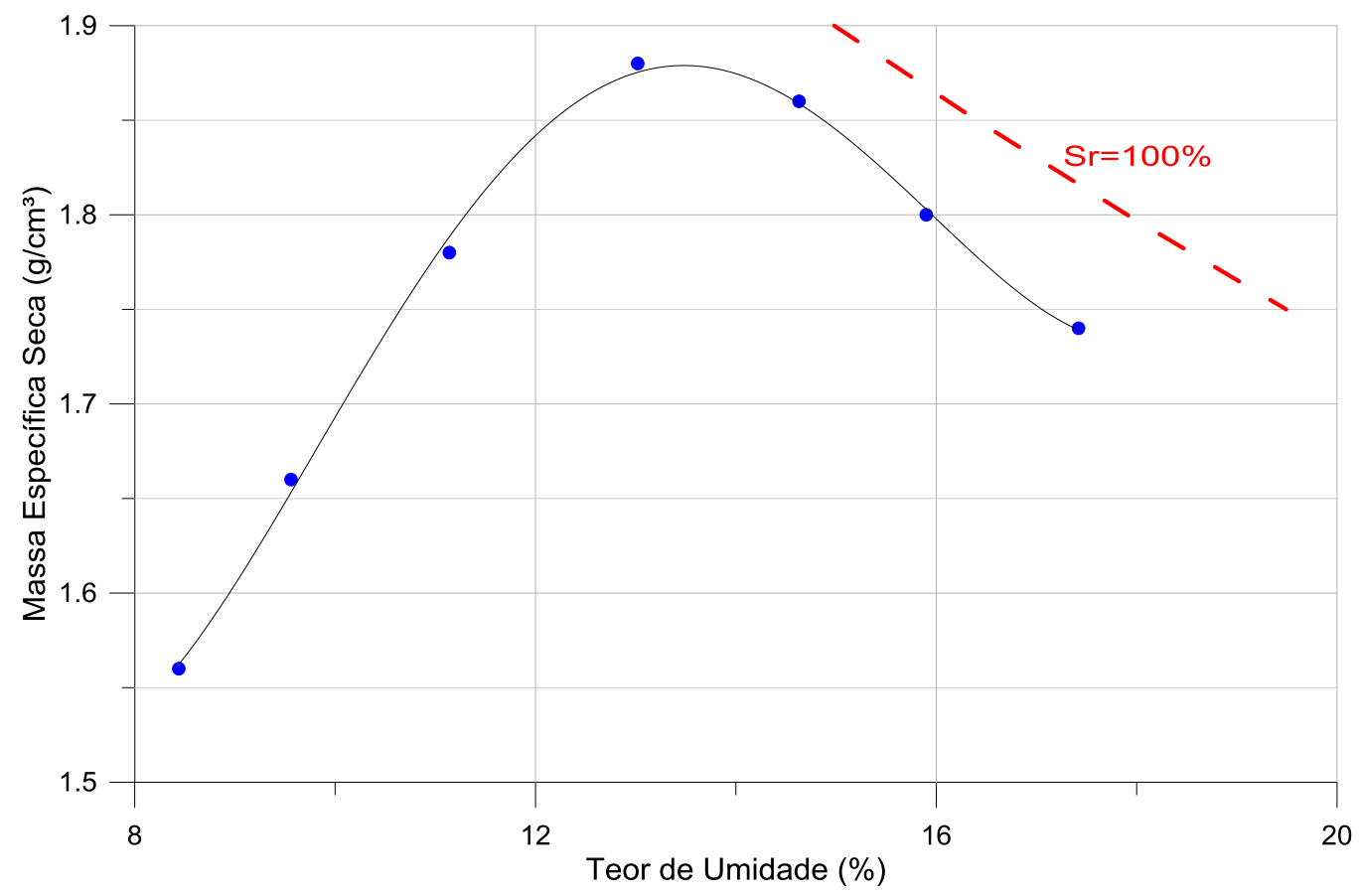

Figura 5.4: Resultados do ensaio de compactação com energia Proctor Normal realizado.

Como síntese dos ensaios de caracterização e de compactação, pode ser organizada a Tabela 5.1 a seguir.

Tabela 5.1: Síntese dos resultados dos ensaios de caracterização e compactação.

\begin{tabular}{|ccc|}
\hline Massa Específica dos Sólidos & $\rho_{S}$ & $2,656 \mathrm{~g} / \mathrm{cm}^{3}$ \\
\hline \multirow{3}{*}{ Limites de Atterberg } & Limite de Liquidez & $22 \%$ \\
& Limite de Plasticidade & $16 \%$ \\
& Índice de Plasticidade & 6 \\
\hline \multirow{3}{*}{ Análise granulométrica conjunta } & Argila & $23 \%$ \\
& Silte & $6 \%$ \\
& Areia fina & $23 \%$ \\
& Areia média & $43 \%$ \\
\multirow{2}{*}{ Compactação (Proctor Normal) } & Areia grossa & $5 \%$ \\
& Massa específica seca máxima $\left(\rho_{d, \text { máx }}\right)$ & $1,88 \mathrm{~g} / \mathrm{cm}^{3}$ \\
& Teor de umidade ótimo $\left(w_{b t}\right)$ & $13,50 \%$ \\
\hline
\end{tabular}

\subsubsection{Ensaios Edométricos}

Foram realizados, nessa etapa, ensaios edométricos simples e duplos. Em um primeiro ensaio edométrico duplo, foi adotado um grau de compactação equivalente a $85 \%$ e teor de 
umidade 3\% inferior ao ótimo (como já comentado anteriormente). Dessa forma, a massa específica seca e o teor de umidade a serem ensaiados equivalem a:

$$
\begin{gathered}
\rho_{d}=0,85 \cdot \rho_{d, \text { máx }}=0,85 \cdot 1,88=1,60 \mathrm{~g} / \mathrm{cm}^{3} \\
w=w_{\text {ót }}-3,0 \%=13,5 \%-3,0 \%=10,5 \%
\end{gathered}
$$

Para atender a esses critérios, sabendo o volume do anel a ser ensaiado, calculou-se a massa de solo necessária para preenchimento do mesmo. Ambos os anéis foram compactados de maneira similar (mesmo grau de compactação, teor de umidade e índice de vazios inicial), sendo um deles ensaiado na condição normal de compactação, do começo ao fim do ensaio (ensaio não inundado, teor de umidade constante e equivalente a 10,5\%) e o outro na condição inundada (permanecendo saturado do começo ao final do ensaio, com a inundação realizada antes do primeiro estágio de carregamento).
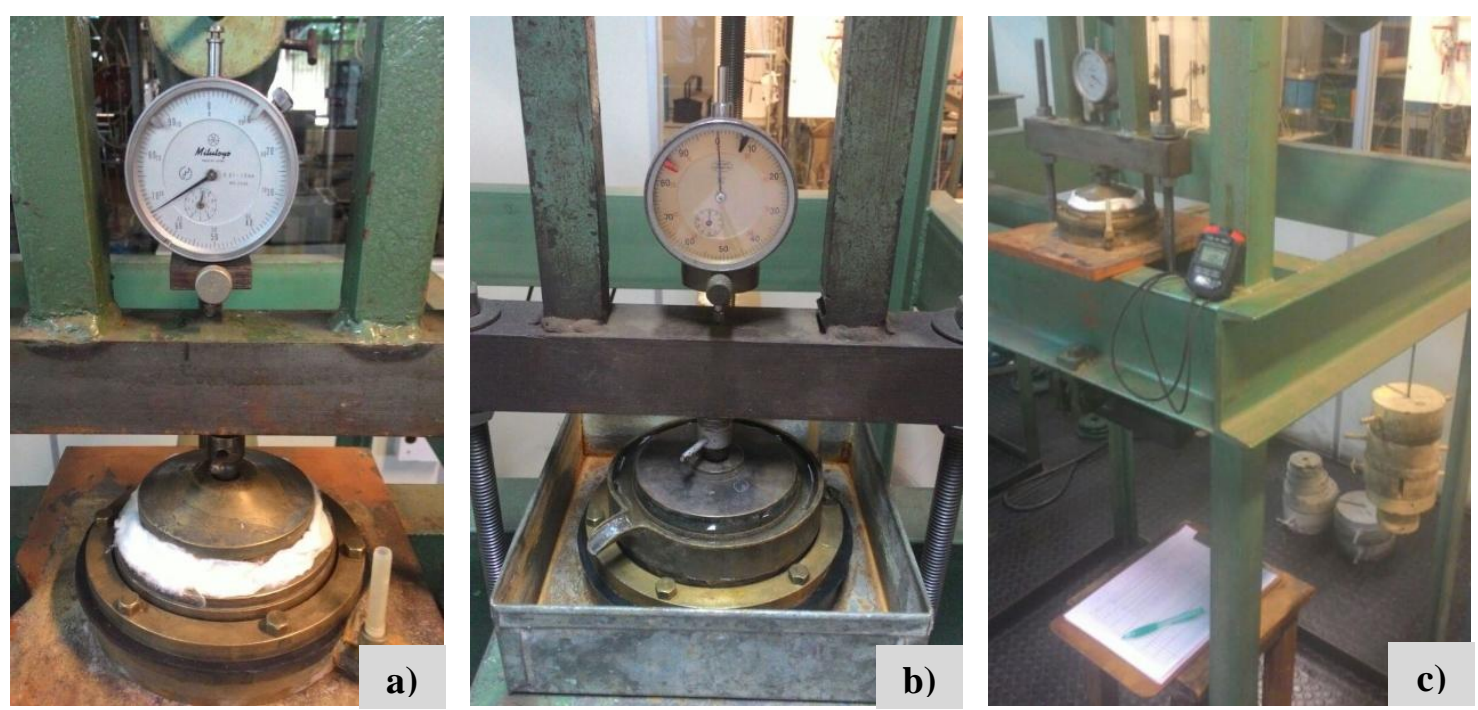

Figura 5.5: Imagens ilustrativas da execução do ensaio do Laboratório de Mecânica dos Solos. Corpo de prova não inundado (a); corpo de prova inundado (b) e estágio de carregamento em andamento (c).

Pode-se, a partir dos parâmetros requeridos, juntamente com o volume do corpo de prova a ser ensaiado (volume do anel) e a massa específica dos sólidos, calcular alguns índices físicos do ensaio executado, tal como demonstrado na Tabela 5.2 a seguir.

Tabela 5.2: Determinação dos índices físicos para o ensaio edométrico duplo realizado com um $G C=85 \%$.

\begin{tabular}{|c|c|c|}
\hline Índice Físico (Unidade) & Símbolo & Valor \\
\hline Volume do Corpo de Prova $\left(\mathrm{cm}^{3}\right)$ & $V$ & 111,60 \\
\hline Massa do Corpo de Prova $(\mathrm{g})$ & $M$ & 196,64 \\
\hline
\end{tabular}




\begin{tabular}{|c|c|c|}
\hline Massa Específica $\left(\mathrm{g} / \mathrm{cm}^{3}\right)$ & $\rho$ & 1,76 \\
\hline Teor de Umidade Gravimétrico (\%) & $w$ & 10,40 \\
\hline Massa Específica Seca $\left(\mathrm{g} / \mathrm{cm}^{3}\right)$ & $\rho_{d}$ & 1,60 \\
\hline Massa Específica dos Sólidos $\left(\mathrm{g} / \mathrm{cm}^{3}\right)$ & $\rho_{s}$ & 2,66 \\
\hline Massa de Sólidos $(\mathrm{g})$ & $M_{s}$ & 178,11 \\
\hline Massa de Água $(\mathrm{g})$ & $M_{w}$ & 18,53 \\
\hline Volume de Sólidos $\left(\mathrm{cm}^{3}\right)$ & $V_{s}$ & 67,06 \\
\hline Volume de Vazios $\left(\mathrm{cm}^{3}\right)$ & $V_{v}$ & 44,54 \\
\hline Volume de Água $\left(\mathrm{cm}^{3}\right)$ & $V_{w}$ & 18,53 \\
\hline Volume de Ar $\left(\mathrm{cm}^{3}\right)$ & $V_{a r}$ & 26,01 \\
\hline Índice de Vazios & $e$ & 0,66 \\
\hline Grau de Saturação (\%) & $S_{r}$ & 41,60 \\
\hline Porosidade $(\%)$ & $n$ & 40,00 \\
\hline Teor de Umidade Volumétrico $(\%)$ & $\theta$ & 16,60 \\
\hline
\end{tabular}

A partir dos índices físicos calculados e da interpretação das leituras obtidas nos diferentes estágios do ensaio, foi possível o traçado do gráfico a seguir, o qual indica o índice de vazios versus a tensão aplicada.

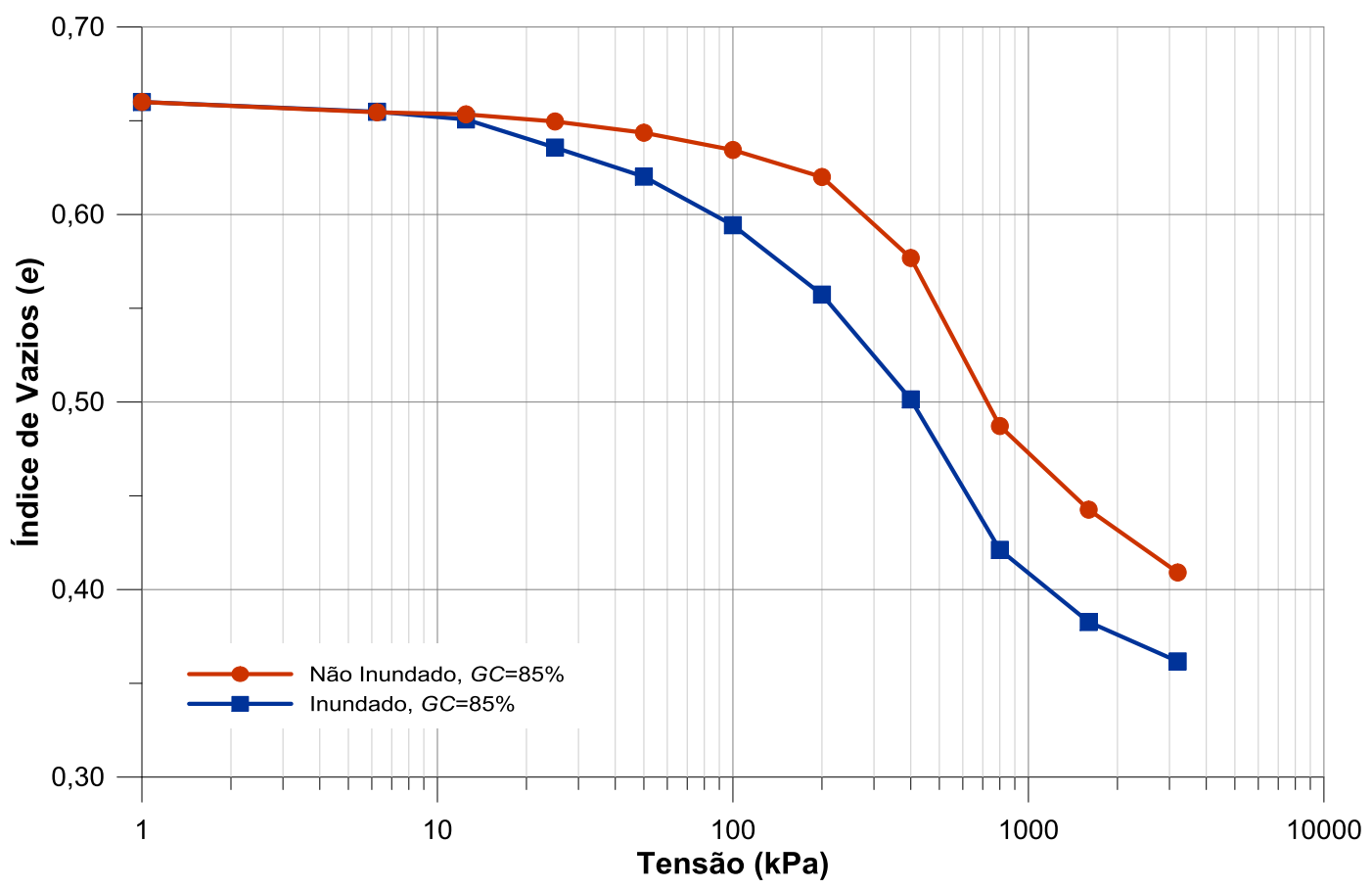

Figura 5.6: Resultados do ensaio edométrico duplo realizado para um $G C=85 \%$.

Uma das vantagens do ensaio edométrico duplo é justamente a obtenção do potencial de colapso para todas as tensões aplicadas, ao passo que no ensaio edométrico simples, o corpo de prova é inundado a uma determinada tensão de interesse, obtendo-se, portanto, o potencial de colapso para apenas aquela tensão específica. Para os diferentes estágios de carregamento 
aplicados, a partir do índice de vazios inicial dos corpos de prova, pôde-se então calcular os diferentes potencias de colapso, de acordo com a Expressão 2.9, conforme ilustrado na Tabela 5.3 a seguir.

Tabela 5.3: Resultado dos potenciais de colapso calculados a partir de ensaio edométrico duplo realizado com um $G C=85 \%$.

\begin{tabular}{|cc|}
\hline Tensão $(\mathbf{k P a})$ & $\boldsymbol{P C}(\boldsymbol{\%})$ \\
\hline 6,25 & 0,00 \\
12,50 & 0,16 \\
25,00 & 0,84 \\
50,00 & 1,41 \\
100,00 & 2,42 \\
200,00 & 3,78 \\
400,00 & 4,54 \\
800,00 & 3,98 \\
1600,00 & 3,61 \\
3200,00 & 2,86 \\
\hline
\end{tabular}

Os potenciais de colapso, para esse caso específico, não ultrapassam, em nenhum momento, o valor de 5\% (podendo ser considerado como limite para gravidade moderada a uma obra). Para maiores tensões, esse potencial é reduzido, uma vez que o solo já foi comprimido o suficiente para expulsão de grande quantidade de ar em seus vazios, devido ao elevado carregamento.

Por experiência de outros autores e pesquisas que envolveram o estudo do solo da atual pesquisa, contudo, julgou-se que o índice de vazios encontrado seria um pouco reduzido, uma vez que tal grandeza, em campo, varia em torno de 1,00 (e foi encontrado, para um $G C=85 \%$, o valor de 0,66). Assim sendo, decidiu-se por repetir o ensaio com um grau de compactação inferior, tal que o índice de vazios aumentasse e aproximasse-se do encontrado em campo (mantendo, contudo, o teor de umidade equivalente a 10,5\%).

Tendo isso em vista, foram executados, então, dois ensaios edométricos simples, sendo um deles para simular o solo na condição de campo (agora mais poroso, com índice de vazios na ordem de 1,00 e $G C=75 \%$ ) e o outro para simular as colunas de solo laterítico compactado nos parâmetros ótimos $(G C=100 \%$ e $w=13,5 \%)$. Os cálculos efetuados e os resultados obtidos encontram-se abaixo ilustrados. 
Tabela 5.4: Determinação dos Índices Físicos para os ensaios edométricos simples realizado para os graus de compactação de $75 \%$ e $100 \%$.

\begin{tabular}{|c|c|c|c|}
\hline Índice Físico (Unidade) & Símbolo & $\boldsymbol{G C}=\mathbf{7 5 \%}$ & $\boldsymbol{G C}=\mathbf{1 0 0 \%}$ \\
\hline Volume do Corpo de Prova $\left(\mathrm{cm}^{3}\right)$ & $V$ & 110,85 & 111,30 \\
\hline Massa do Corpo de Prova $(\mathrm{g})$ & $M$ & 171,02 & 236,80 \\
\hline Massa Específica $\left(\mathrm{g} / \mathrm{cm}^{3}\right)$ & $\rho$ & 1,54 & 2,13 \\
\hline Teor de Umidade Gravimétrico $(\%)$ & $w$ & 9,70 & 12,70 \\
\hline Massa Específica Seca $\left(\mathrm{g} / \mathrm{cm}^{3}\right)$ & $\rho_{d}$ & 1,41 & 1,88 \\
\hline Massa Específica dos Sólidos $\left(\mathrm{g} / \mathrm{cm}^{3}\right)$ & $\rho_{s}$ & 2,66 & 2,66 \\
\hline Massa de Sólidos $(\mathrm{g})$ & $M_{s}$ & 155,90 & 210,12 \\
\hline Massa de Água $(\mathrm{g})$ & $M_{w}$ & 15,12 & 26,68 \\
\hline Volume de Sólidos $\left(\mathrm{cm}^{3}\right)$ & $V_{s}$ & 58,71 & 79,11 \\
\hline Volume de Vazios $\left(\mathrm{cm}^{3}\right)$ & $V_{v}$ & 52,15 & 32,19 \\
\hline Volume de Água $\left(\mathrm{cm}^{3}\right)$ & $V_{w}$ & 15,12 & 26,68 \\
\hline Volume de Ar $\left(\mathrm{cm}^{3}\right)$ & $V_{a r}$ & 37,03 & 5,51 \\
\hline Índice de Vazios & $e$ & 0,889 & 0,407 \\
\hline Grau de Saturação $(\%)$ & $S_{r}$ & 29,00 & 82,90 \\
\hline Porosidade $(\%)$ & $n$ & 47,05 & 28,92 \\
\hline Teor de Umidade Volumétrico $(\%)$ & $\theta$ & 13,64 & 23,97 \\
\hline
\end{tabular}

Para ambos os ensaios, procedeu-se a inundação do corpo de prova a um carregamento equivalente a $100 \mathrm{kPa}$. A partir do ocorrido no momento da inundação, foi possível o cálculo do potencial de colapso para ambos os ensaios, conforme ilustrado na Tabela 5.5.

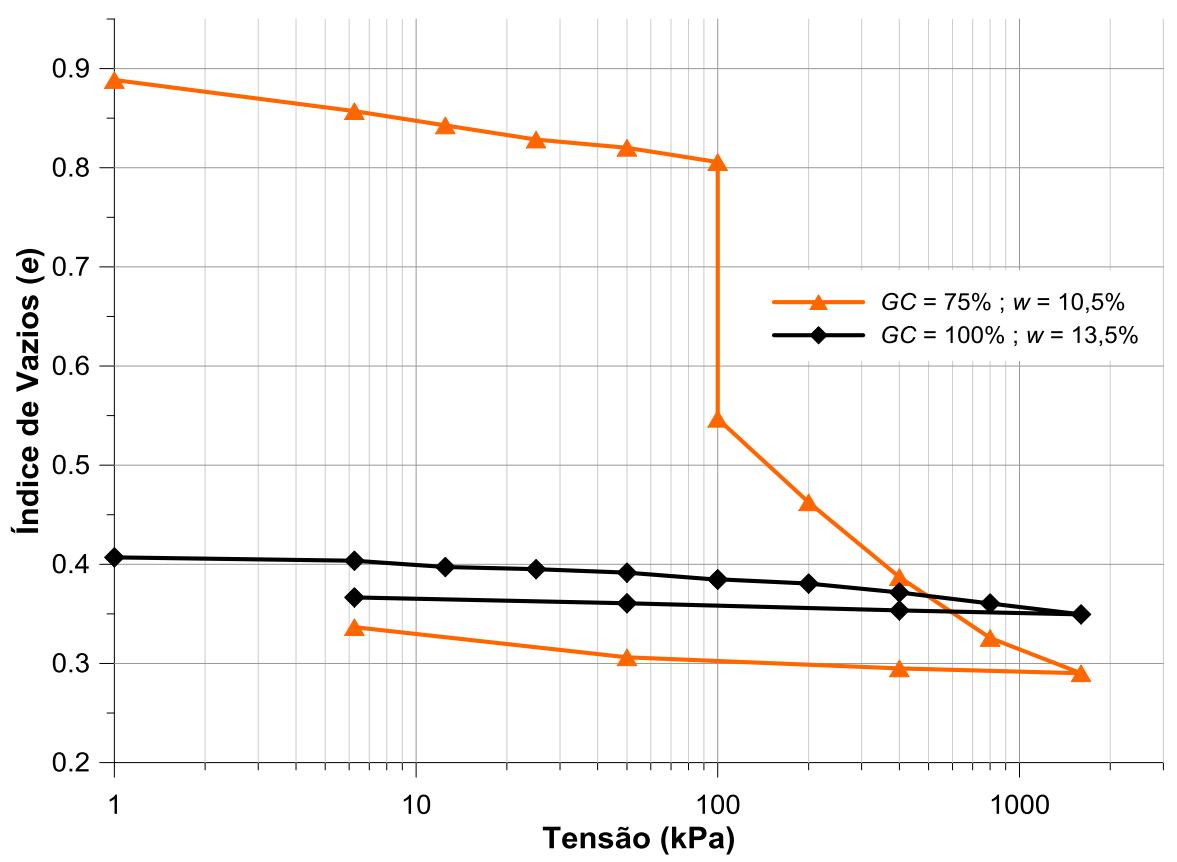

Figura 5.7: Resultados dos ensaios edométricos simples realizados para os graus de compactação de $75 \%$ e $100 \%$. 
Tabela 5.5: Resultado dos potenciais de colapso calculados a partir dos ensaios edométricos simples realizados.

\begin{tabular}{|c|cc|}
\hline Ensaio & $\boldsymbol{G C}(\boldsymbol{\%})$ & $\boldsymbol{P C}(\boldsymbol{\%})$ \\
\hline $\mathbf{1}$ & 75,00 & 14,00 \\
$\mathbf{2}$ & 100,00 & 0,00 \\
\hline
\end{tabular}

A partir dos ensaios supracitados, tornou-se evidente o efeito da compactação de um solo laterítico quanto ao fenômeno de colapso, uma vez que não houve nenhuma perturbação da estrutura no momento da inundação quando verificadas as condições ótimas de compactação $(G C=100 \%)$; ao passo que para a situação do campo $(G C=75 \%$, extremamente porosa e com teor de umidade aquém do ótimo) houve um deslocamento repentino e pronunciado (colapso).

Por fim, ainda, foi testado outro grau de compactação, intermediário, em um ensaio edométrico duplo, para avaliação do efeito de colapso e melhor entendimento do solo estudado. Adotou-se agora um $G C=80 \%$, como condição intermediária aos já estudados (85\% e 75\%), para noção do potencial de colapso nessa condição de compacidade. Os resultados obtidos são ilustrados na Figura 5.8 abaixo.

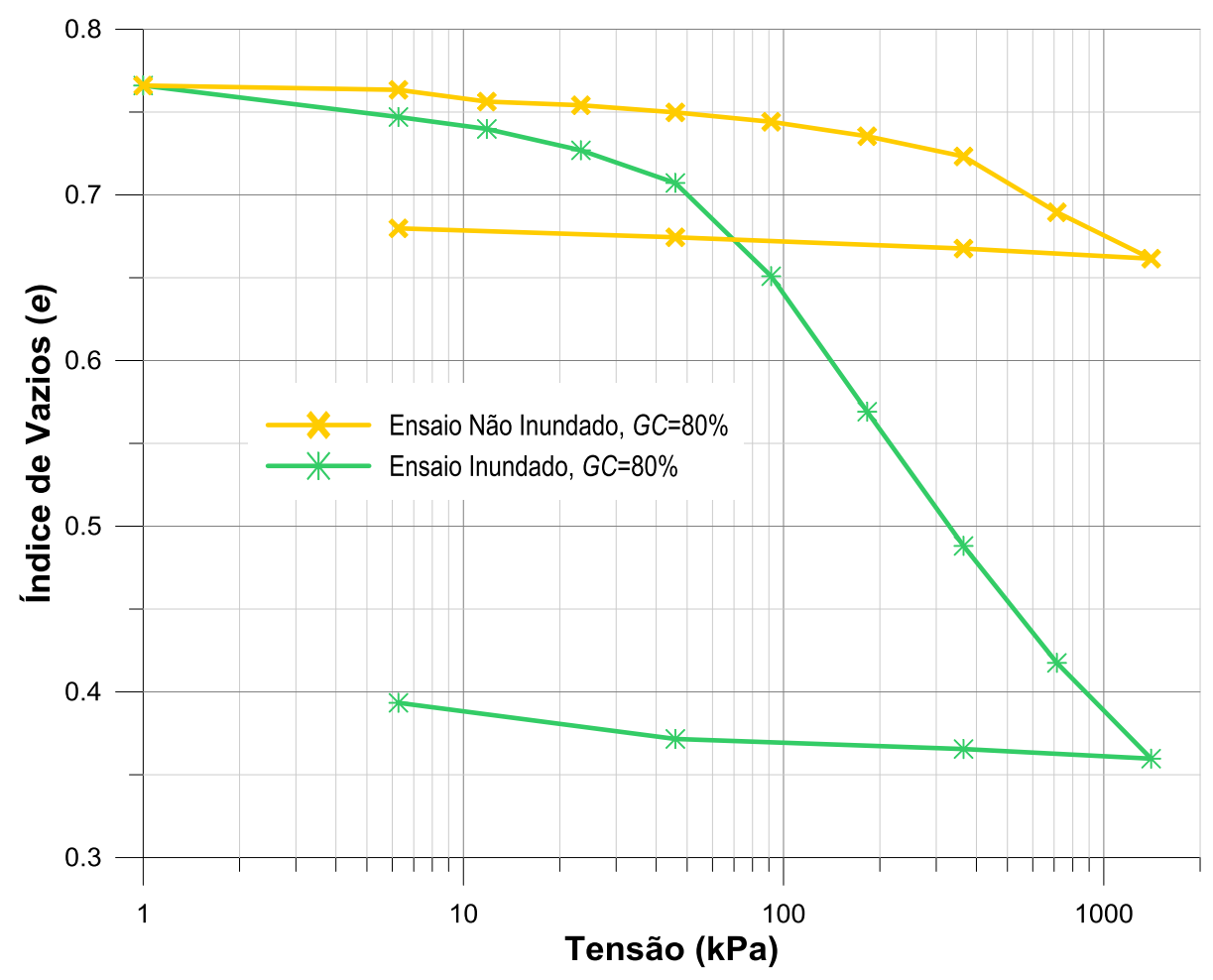

Figura 5.8: Resultado do ensaio edométrico duplo realizado para um $G C$ de $80 \%$. 
Tabela 5.6: Determinação dos índices físicos para o ensaio edométrico duplo realizado com um $G C=80 \%$.

\begin{tabular}{|c|c|c|}
\hline Índice Físico (Unidade) & Símbolo & Valor \\
\hline Volume do Corpo de Prova $\left(\mathrm{cm}^{3}\right)$ & $V$ & 111,60 \\
\hline Massa do Corpo de Prova $(\mathrm{g})$ & $M$ & 185,26 \\
\hline Massa Específica $\left(\mathrm{g} / \mathrm{cm}^{3}\right)$ & $\rho$ & 1,66 \\
\hline Teor de Umidade Gravimétrico $(\%)$ & $w$ & 10,40 \\
\hline Massa Específica Seca $\left(\mathrm{g} / \mathrm{cm}^{3}\right)$ & $\rho_{d}$ & 1,50 \\
\hline Massa Específica dos Sólidos $\left(\mathrm{g} / \mathrm{cm}^{3}\right)$ & $\rho_{s}$ & 2,66 \\
\hline Massa de Sólidos $(\mathrm{g})$ & $M_{s}$ & 167,81 \\
\hline Massa de Água $(\mathrm{g})$ & $M_{w}$ & 17,45 \\
\hline Volume de Sólidos $\left(\mathrm{cm}^{3}\right)$ & $V_{s}$ & 63,18 \\
\hline Volume de Vazios $\left(\mathrm{cm}^{3}\right)$ & $V_{v}$ & 48,42 \\
\hline Volume de Água $\left(\mathrm{cm}^{3}\right)$ & $V_{w}$ & 17,45 \\
\hline Volume de Ar $\left(\mathrm{cm}^{3}\right)$ & $V_{a r}$ & 30,96 \\
\hline Índice de Vazios & $e$ & 0,77 \\
\hline Grau de Saturação $(\%)$ & $S_{r}$ & 36,05 \\
\hline Porosidade $(\%)$ & $n$ & 0,434 \\
\hline Teor de Umidade Volumétrico $(\%)$ & $\theta$ & 15,64 \\
\hline
\end{tabular}

Tabela 5.7: Resultado dos potenciais de colapso calculados a partir de ensaio edométrico duplo realizado com um $G C=80 \%$.

\begin{tabular}{|cc|}
\hline Tensão (kPa) & $\boldsymbol{P C}(\boldsymbol{\%})$ \\
\hline 6,25 & 0,93 \\
12,50 & 0,93 \\
25,00 & 1,54 \\
50,00 & 2,41 \\
100,00 & 5,28 \\
200,00 & 9,42 \\
400,00 & 13,31 \\
800,00 & 15,40 \\
1600,00 & 17,09 \\
\hline
\end{tabular}

Como síntese comparativa de todos os ensaios edométricos realizados para o estudo em questão, são apresentados a seguir todos os resultados compilados. 


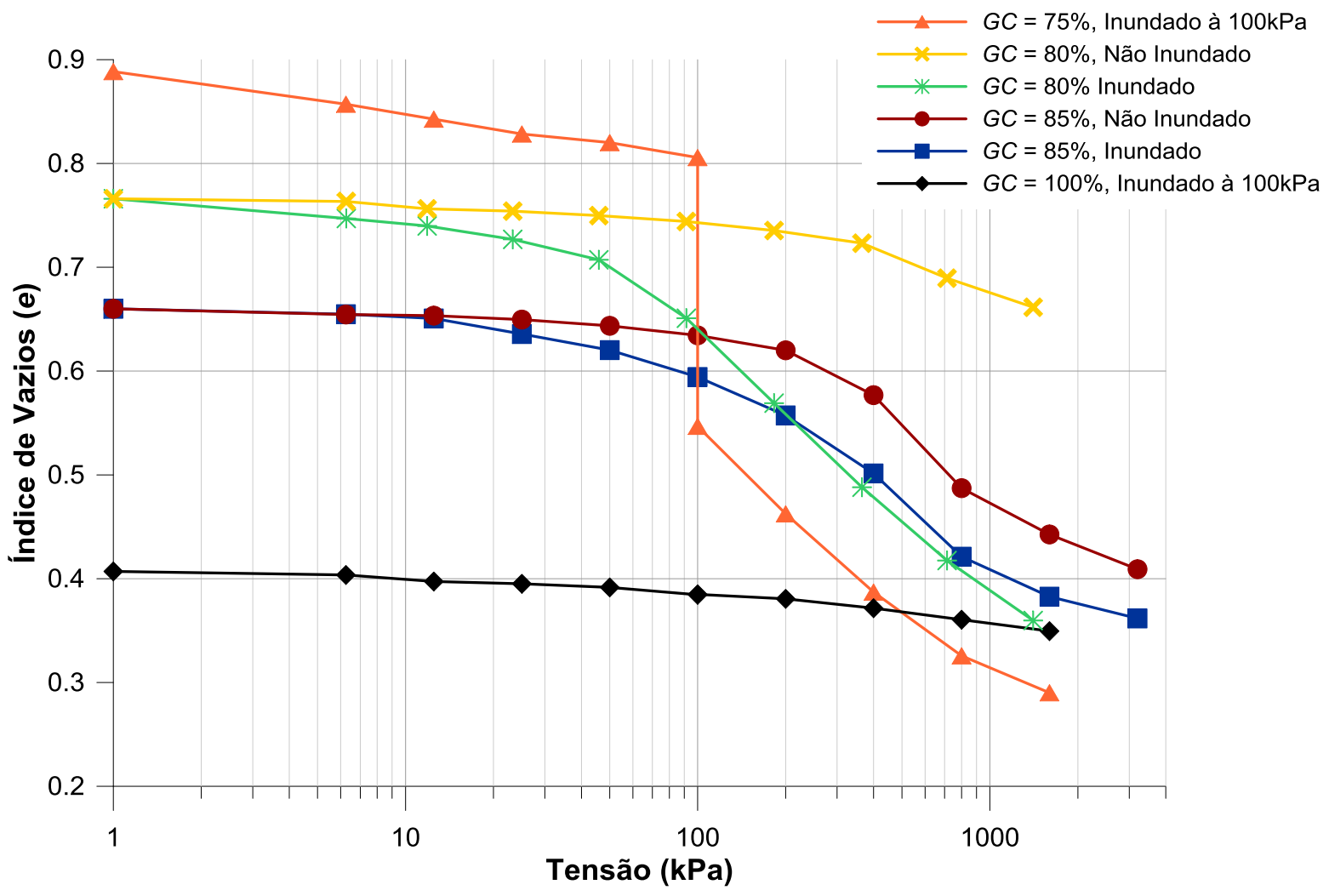

Figura 5.9: Síntese de todos os ensaios edométricos realizados para o solo estudado.

Tabela 5.8: Compilação dos resultados obtidos dos ensaios edométricos realizados.

\begin{tabular}{|c|cccc|}
\hline & $\boldsymbol{G C}=\mathbf{7 5 \%}$ & $\mathbf{G C}=\mathbf{8 0} \%$ & $\boldsymbol{G C}=\mathbf{8 5 \%}$ & $\boldsymbol{G C}=\mathbf{1 0 0 \%}$ \\
\hline$\rho\left(\mathrm{g} / \mathrm{cm}^{3}\right)$ & 1,54 & 1,66 & 1,76 & 2,13 \\
$w(\%)$ & 9,70 & 10,40 & 10,40 & 12,70 \\
$\rho_{d}\left(\mathrm{~g} / \mathrm{cm}^{3}\right)$ & 1,41 & 1,50 & 1,60 & 1,88 \\
$e$ & 0,889 & 0,77 & 0,66 & 0,407 \\
$S_{r}(\%)$ & 29,00 & 36,05 & 41,60 & 82,90 \\
$n$ & 0,471 & 0,434 & 0,400 & 28,92 \\
$\theta(\%)$ & 13,64 & 15,64 & 16,60 & 23,97 \\
$P C(\%)$ para $100 \mathrm{kPa}$ & 14,00 & 5,28 & 2,42 & 0,00 \\
\hline
\end{tabular}




\subsection{Modelagem Física a $1 \mathrm{~g}$}

Um primeiro modelo físico não centrifugado foi realizado em uma caixa de madeirite de dimensões conhecidas, subdividida em alturas de $25 \mathrm{~mm}$. O grau de compactação inicialmente escolhido foi o referente a $85 \%$ e a variação do teor de umidade foi equivalente a $-3 \%$.

$$
\begin{gathered}
\rho_{d}=0,85 \cdot \rho_{d, m a ́ x}=0,85 \cdot 1,88=1,60 \mathrm{~g} / \mathrm{cm}^{3} \\
w=w_{\text {ót }}-3,0 \%=13,5 \%-3,0 \%=10,5 \% \\
\rho=\rho_{d} \cdot(1+w)=1,60 \cdot(1,105)=1,768 \mathrm{~g} / \mathrm{cm}^{3} \\
\rho=\frac{m}{V} \rightarrow m=\rho \cdot V=1,768 \cdot 30 \cdot 24 \cdot 2,5=3182 \mathrm{~g} .
\end{gathered}
$$

A cada camada de $25 \mathrm{~mm}$ da caixa ensaiada, foram então compactados 3182 gramas de solo, com teor de umidade de $10,5 \%$ para assim tentar simular o grau de compactação de $85 \%$ desejado.

Para compactação das camadas foi utilizado um soquete de massa equivalente a 4 quilos e com altura de queda máxima de 35 centímetros. A energia de compactação não foi controlada. O único controle para o processo de compactação foi o de volume a ser atendido por camada. As etapas do experimento são ilustradas a seguir.
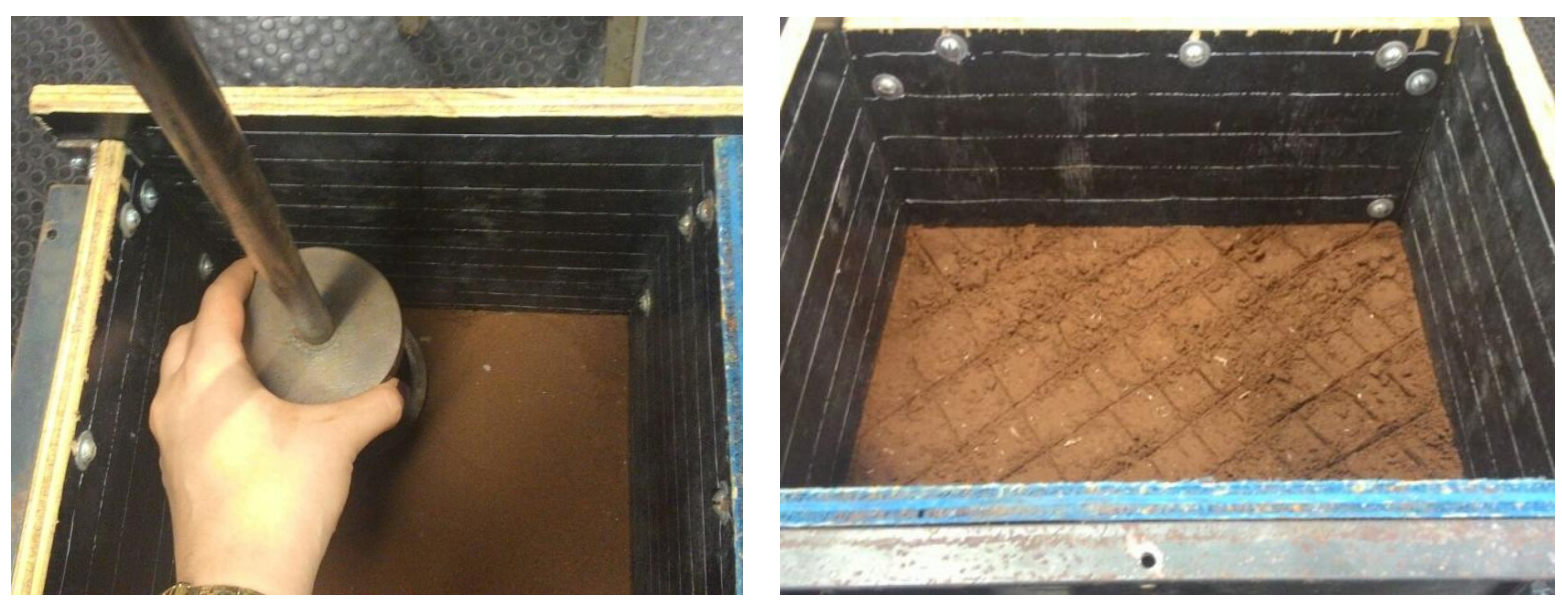

Figura 5.10: Compactação do solo com o soquete (a) e camada compactada no volume estipulado com escarificação da mesma para melhor entrosamento com a posterior (b) 

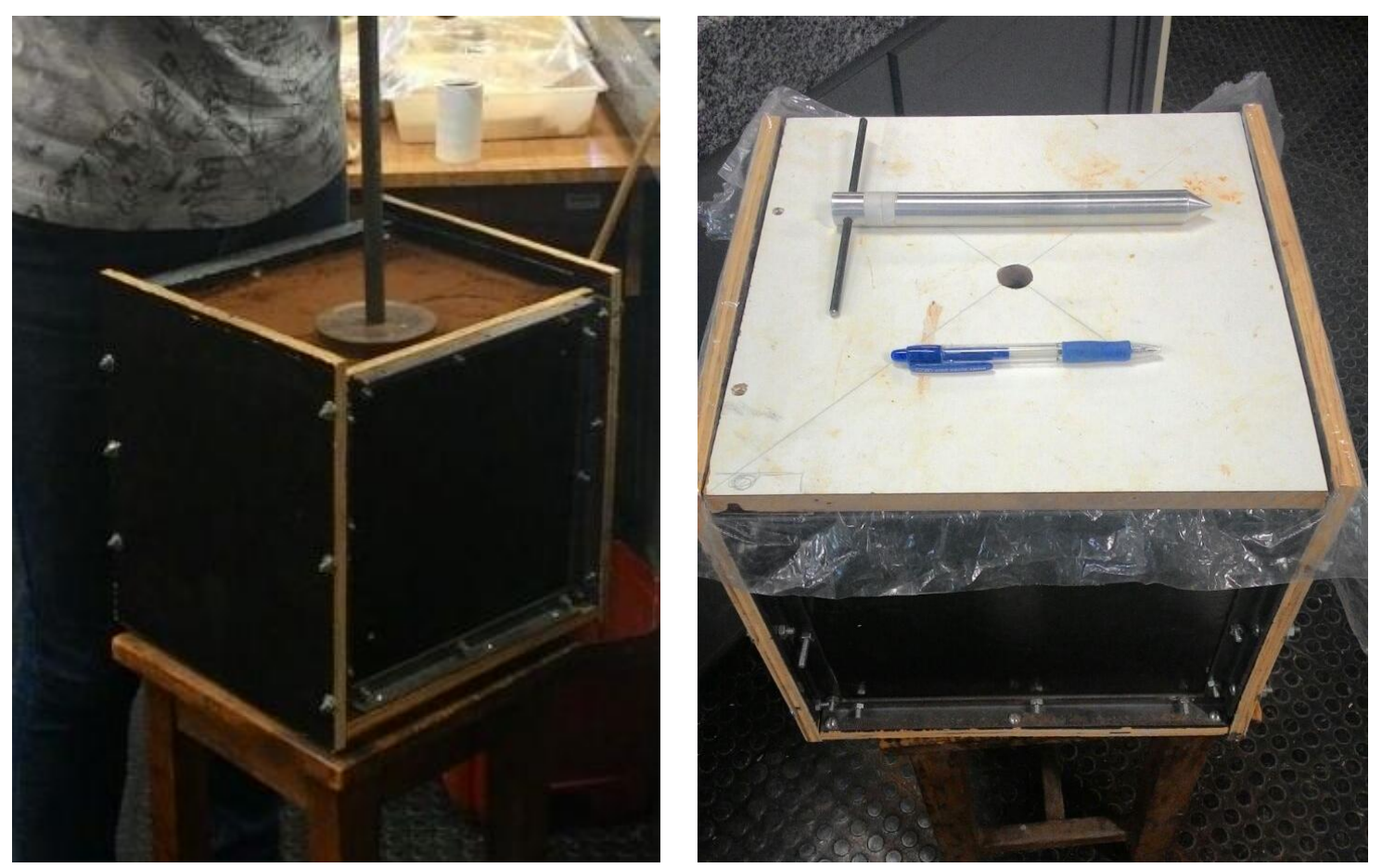

Figura 5.11: Etapa final de compactação da caixa (a) e colocação da placa gabarito para cravação da coluna metálica (b).
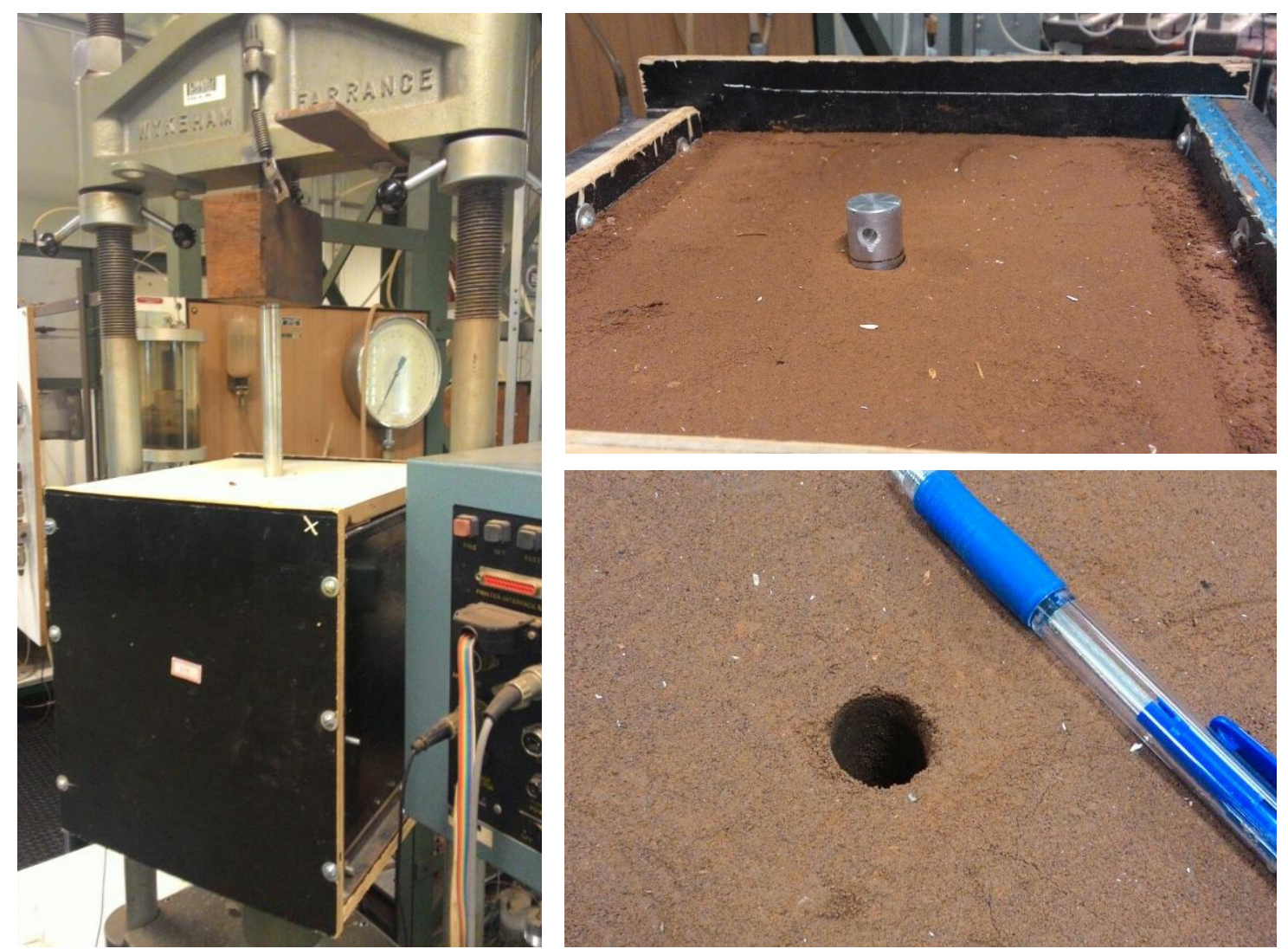

Figura 5.12: Processo de cravação da coluna através da prensa (a), coluna ao final do processo de cravação (b) e furo após retirada da coluna metálica (c). 
Para preenchimento do furo obtido foi utilizado o próprio solo, no teor de umidade ótimo de compactação (13,5\%), visando obter um grau de compactação de $100 \%$. Foram então pré-determinadas alturas de $25 \mathrm{~mm}$ (galgadas no soquete compactador) e procedeu-se o cálculo da massa de solo para cada camada analogamente à execução da caixa.

$$
\begin{gathered}
\rho=\rho_{d_{\text {máx }}}\left(1+w_{\text {ót }}\right)=1,88(1+0,135)=2,13 \mathrm{~g} / \mathrm{cm}^{3} \\
\rho=\frac{m}{V} \rightarrow 2,13=\frac{m}{\pi \cdot 2^{2} / 4 \cdot 2,5} \rightarrow m=16,8 \mathrm{~g} \text { de solo } / \text { camada }
\end{gathered}
$$

Novamente, o processo de compactação não foi controlado pela energia, mas sim pelo volume (altura a ser compactada) a partir do grau de compactação e teor de umidade desejados.
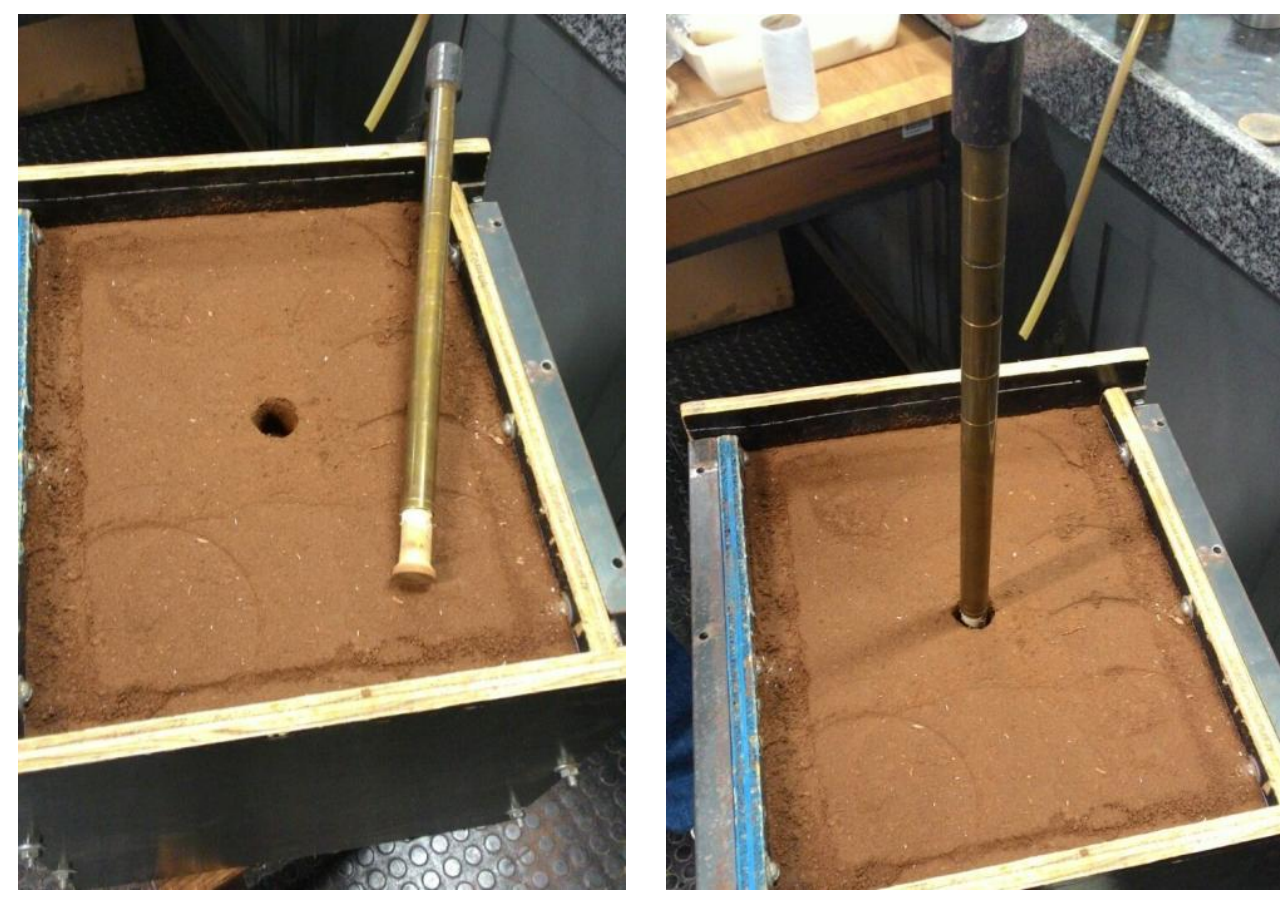

Figura 5.13: Soquete utilizado para compactação do solo no furo da coluna, galgado com 2,50 $\mathrm{cm}$ de altura para o controle de camadas.

Por fim, executou-se a escarificação da caixa no intuito de obter o teor de umidade e a massa específica seca do material compactado e da coluna e verificar se ambos atenderam aos parâmetros de compactação requeridos. 

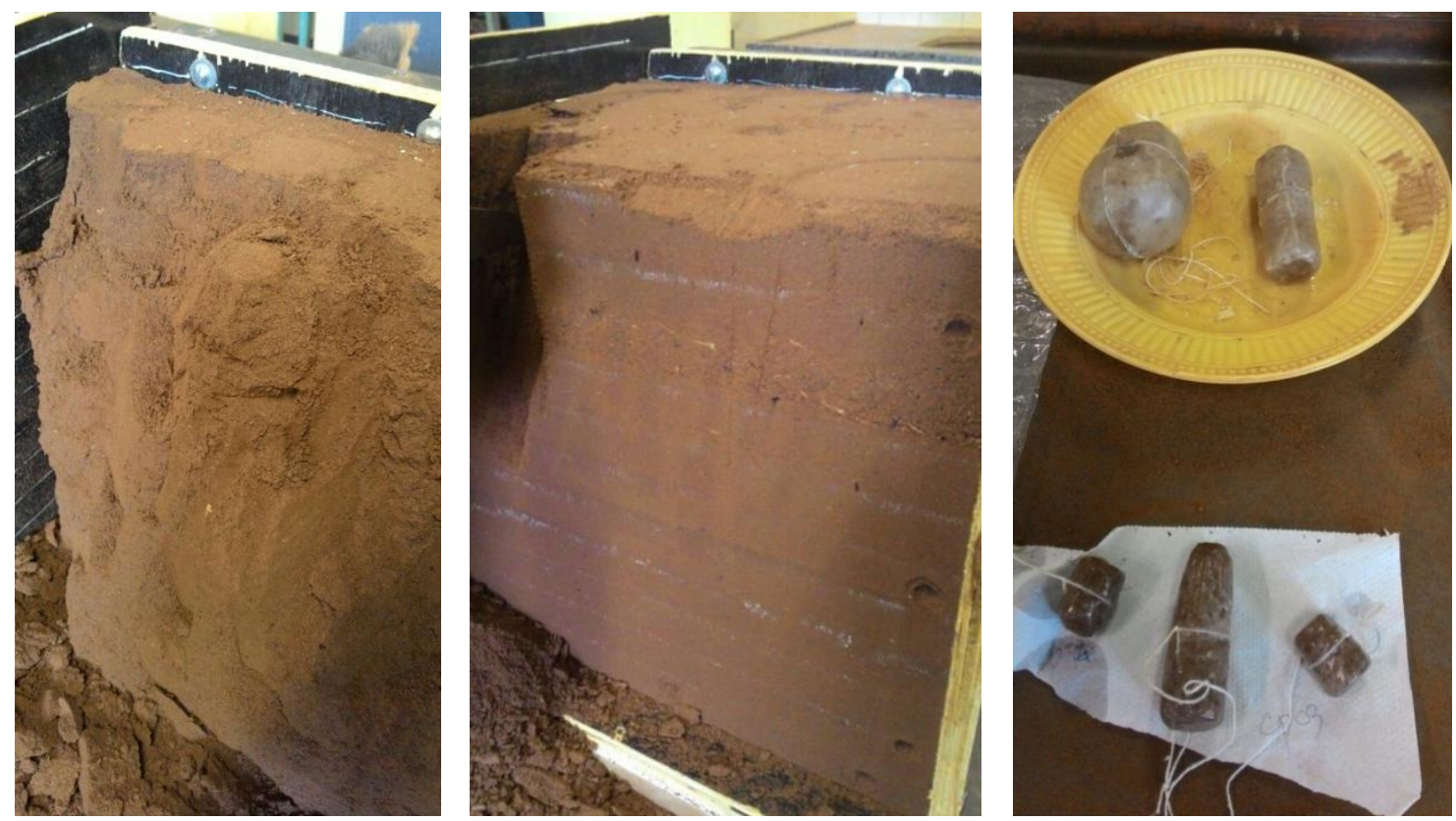

Figura 5.14: Escarificação da caixa executada e procedimento de determinação da massa específica pela determinação do volume por submersão.

O solo compactado na caixa resultou em um teor de umidade de $10,2 \%$ e uma massa específica seca equivalente a $1,51 \mathrm{~g} / \mathrm{cm}^{3}$ (referente a um grau de compactação de $80 \%$ ). Já o material de preenchimento da coluna resultou em um teor de umidade de $13,1 \%$ e uma massa específica seca de $1,70 \mathrm{~g} / \mathrm{cm}^{3}$, o que confere um grau de compactação de 90,5\% (relativamente baixo, uma vez que era visado um $G C$ de $100 \%$ ).

Tais desvios provavelmente devem-se ao fato de que, como a massa para preenchimento de cada camada da coluna era muito pequena, a perda de umidade entre seus processos de pesagem e compactação era rápida, resultando em um teor de umidade um pouco inferior ao ótimo. Além disso, o processo de compactação da coluna novamente foi controlado apenas pelo volume, e não pela energia aplicada. Dessa forma, tendo o volume sido atingido, não foi garantido, nesse caso, que a massa específica seca adequava-se ao previsto, uma vez que a coluna pode ter aumentado de diâmetro (deslocamento radial do solo no entorno) e também aumentado de profundidade (deslocamento vertical da ponta da coluna), mascarando os resultados.

Como não foi adicionado nenhum material que diferenciasse o solo de preenchimento da coluna do solo do restante da caixa (como algum corante, cal, gesso, talco e entre outros), 
não foi possível a análise visual da geometria final da coluna na escarificação da caixa, não sendo possível verificar se ocorreu uma deformação radial ou longitudinal significativa.

Assim sendo, foi realizado outro ensaio, agora com um material de preenchimento diferenciado para as colunas, de tal forma que fosse possível a verificação de sua geometria final após a escarificação. Foram agora executadas três colunas, duas delas compostas de argila alaranjada (de características conhecidas) e espaçadas em $4 d$ (simulando o espaçamento a ser testado em centrífuga) e uma terceira composta do solo estudado nos parâmetros ótimos. A compactação da caixa foi feita de maneira análoga ao ensaio anterior, agora com um grau de compactação equivalente a $80 \%$ e teor de umidade equivalente a $10,5 \%$.
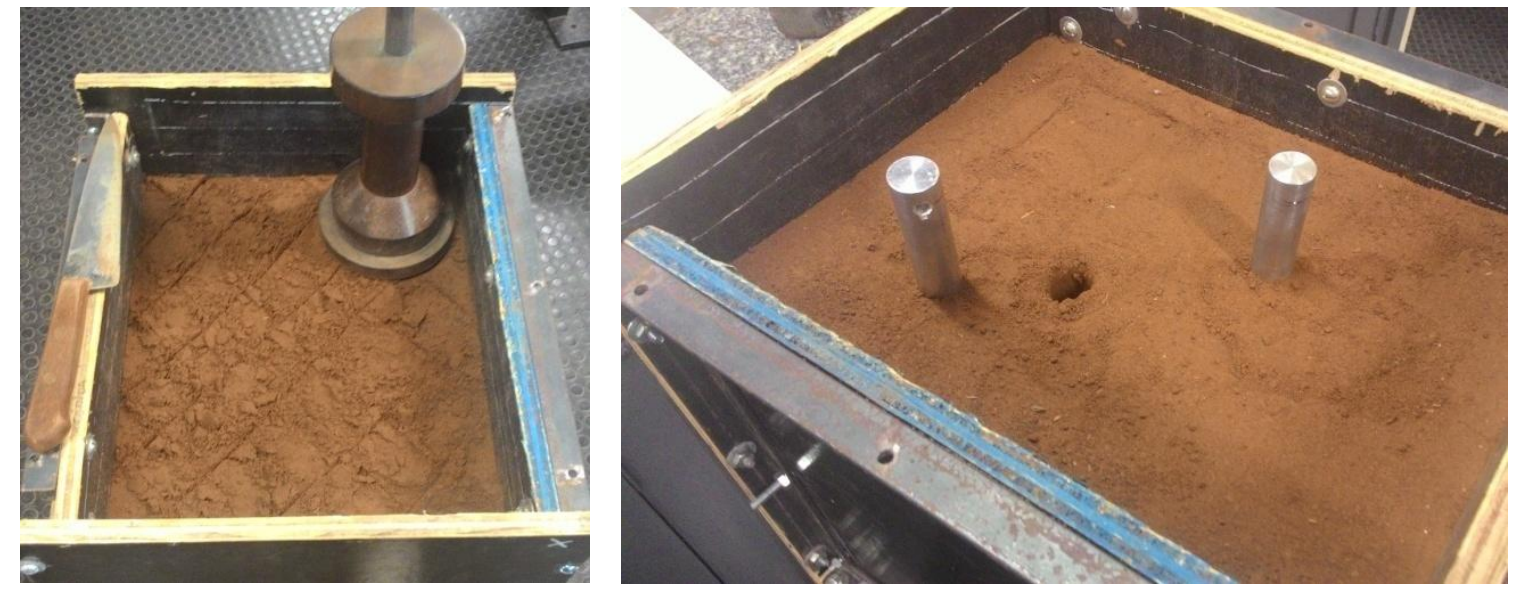

Figura 5.15: Execução do segundo modelo físico para noção da geometria da coluna compactada.
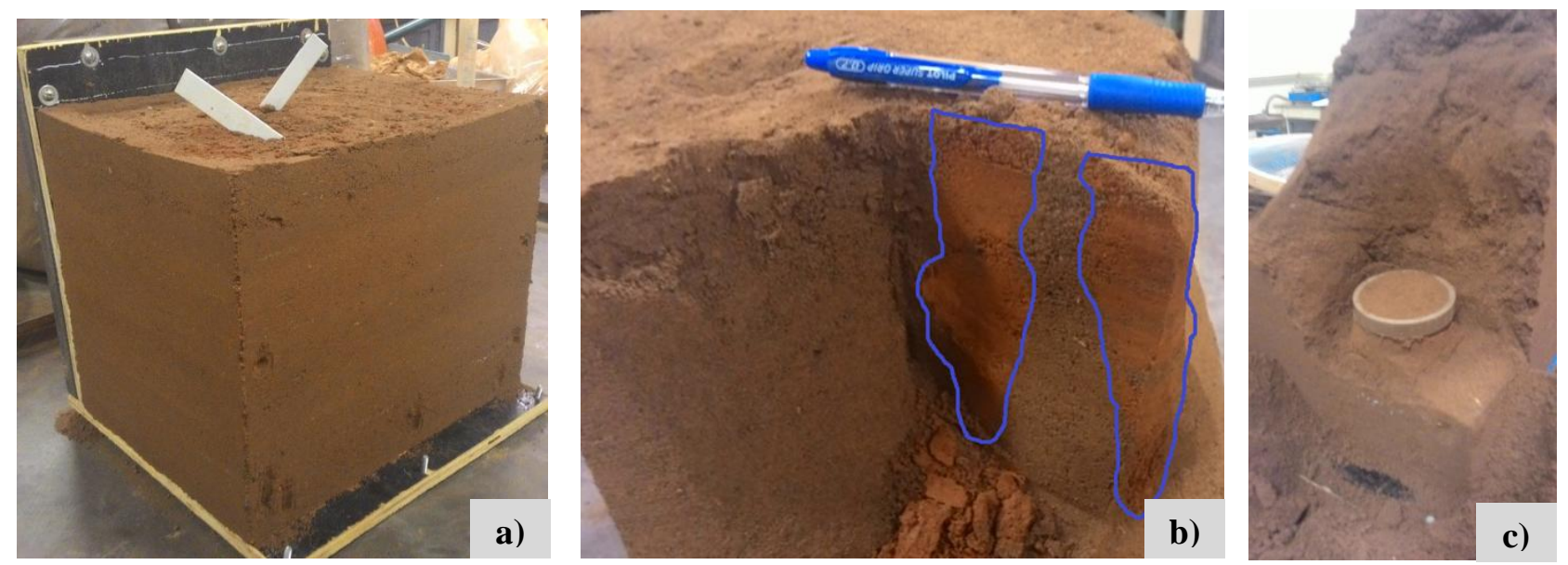

Figura 5.16: Abertura da caixa para escarificação (a), geometria das colunas de argila compactadas (b) e retirada de amostras indeformadas para obtenção dos índices físicos (c).

Da retirada de amostras indeformadas com anéis de PVC, foi possível o cálculo dos índices físicos, tanto da coluna de solo laterítico compactado quanto do solo de preenchimento 
da caixa. Foram retiradas amostras do topo, do meio e da base de ambos e então calculadas as médias, que estão apresentadas na Tabela 5.9 abaixo.

Tabela 5.9: Índices físicos das amostras retiradas da coluna de solo laterítico compactado e da caixa simulando a situação de campo no modelo físico não centrifugado.

\begin{tabular}{|c|cc|}
\hline \multicolumn{2}{|c|}{ Coluna } & Solo da Caixa \\
\hline$V\left(\mathrm{~cm}^{3}\right)$ & 19,63 & 22,35 \\
$M(\mathrm{~g})$ & 40,50 & 37,04 \\
$w(\%)$ & 13,3 & 10,5 \\
$\rho\left(\mathrm{g} / \mathrm{cm}^{3}\right)$ & 2,06 & 1,66 \\
$\rho_{d}\left(\mathrm{~g} / \mathrm{cm}^{3}\right)$ & 1,82 & 1,50 \\
$G C(\%)$ & $97 \%$ & $80 \%$ \\
$\rho_{s}\left(\mathrm{~g} / \mathrm{cm}^{3}\right)$ & 2,66 & 2,66 \\
$M_{s}(\mathrm{~g})$ & 35,75 & 33,52 \\
$V_{s}\left(\mathrm{~cm}^{3}\right)$ & 13,46 & 12,62 \\
$V_{v}\left(\mathrm{~cm}^{3}\right)$ & 6,17 & 9,73 \\
$V_{w}\left(\mathrm{~cm}^{3}\right)$ & 4,75 & 3,52 \\
$V_{a r}\left(\mathrm{~cm}^{3}\right)$ & 1,42 & 6,21 \\
$e$ & 0,46 & 0,77 \\
$S_{r}(\%)$ & $77,0 \%$ & $36,2 \%$ \\
$n$ & 0,31 & 0,44 \\
\hline
\end{tabular}

Nota-se dos dados apresentados acima que os parâmetros obtidos assemelharam-se muito mais dos requeridos inicialmente, sendo considerados satisfatórios. A coluna ficou próxima dos parâmetros ótimos de compactação e o solo da caixa ficou exatamente tal como requerido ( $G C$ de $80 \%$ e teor de umidade de $10,5 \%)$.

Da escarificação das colunas de argila, notou-se uma modificação em sua geometria inicial (equivalente à da coluna metálica cravada), tendo um considerável aumento radial. Apesar das duas colunas de argila não terem se encostado, não significa necessariamente que o solo adjacente não tenha sofrido melhorias devido ao processo da cravação e compactação.

Por fim, para noção da geometria de uma coluna compactada com o solo estudado, fez-se um terceiro modelo físico com uma única coluna de solo misturado com caulim (um argilomineral branco) para destaque da mesma e possibilidade de contraste com o solo simulando as condições de campo. Como seria realizada apenas uma coluna, utilizou-se, ao invés da caixa de madeirite, um cilindro de Proctor modificado para compactação do solo nas condições de campo. 
Dessa vez, foi adotado um grau de compactação de $75 \%$ e o mesmo teor de umidade de 10,5\% como condições de campo. A compactação do cilindro deu-se em cinco camadas de altura iguais, com escarificação entre elas, e realizada através de um disco de aço de mesmo diâmetro interno do cilindro sob a atuação da queda livre de uma massa presa a uma haste (na qual houve o controle da altura da camada). A cravação da coluna metálica ocorreu através da prensa do laboratório de mecânica dos solos e, após sua retirada, verificou-se que o furo manteve-se bem estável. Sua cravação deu-se até uma profundidade de $150 \mathrm{~mm}$. Tal cilindro foi escolhido por ser bipartido e possibilitar sua abertura e facilitar a escarificação da coluna.

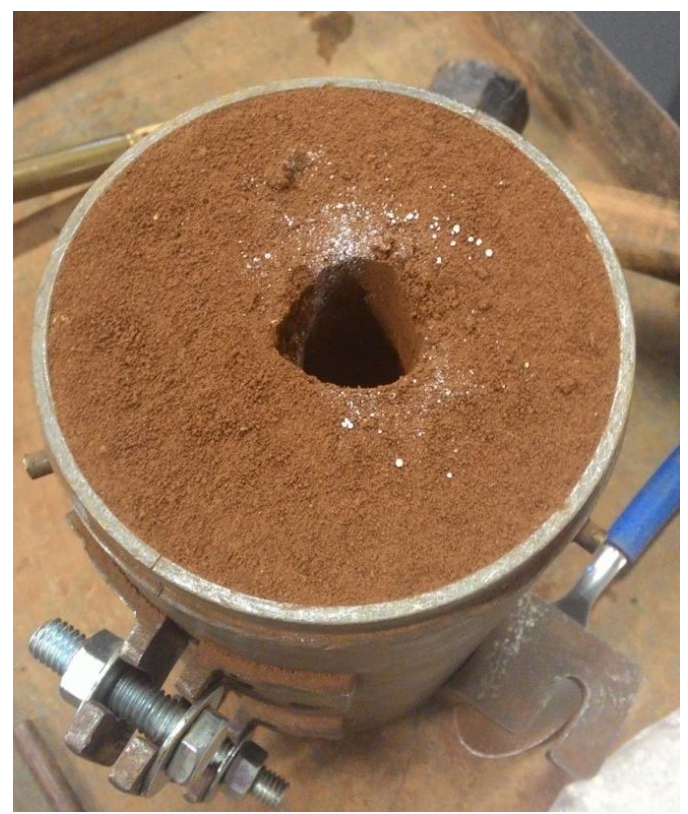

Figura 5.17: Cilindro de Proctor modificado para compactação do solo e furo da coluna após cravação e retirada da coluna metálica.
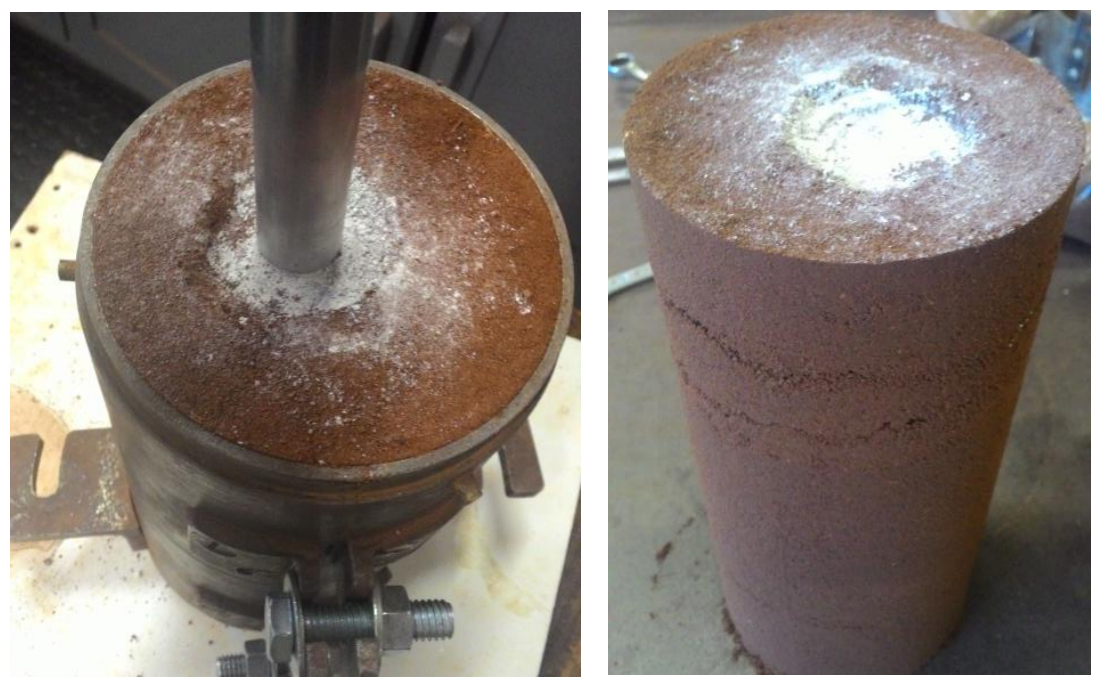

Figura 5.18: Coluna após término de sua compactação. À esquerda, comparação com a dimensão inicial do furo (coluna metálica) e à direita corpo de prova após abertura do cilindro. 

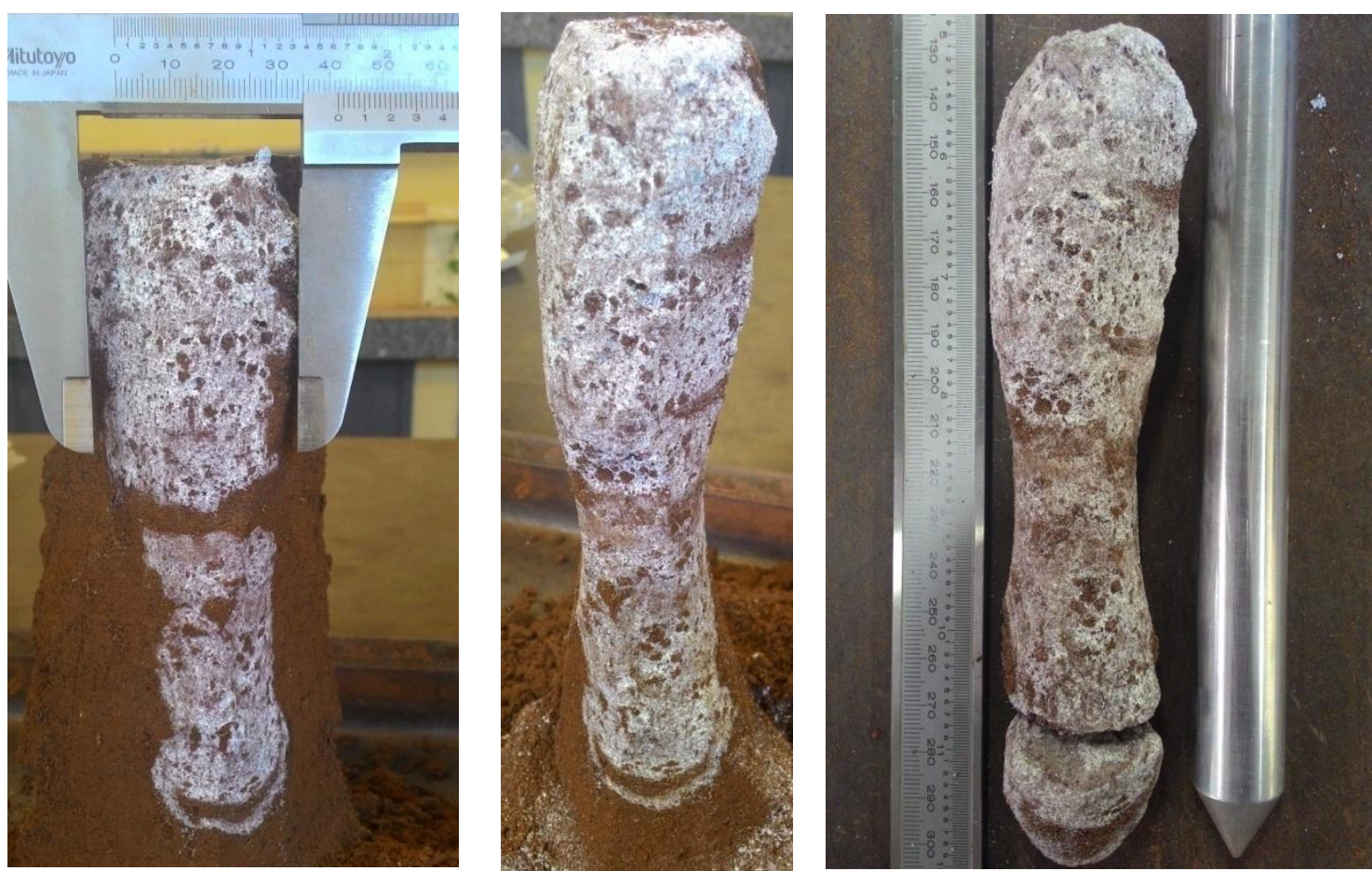

Figura 5.19: Seção longitudinal da coluna com caulim após sua escarificação.
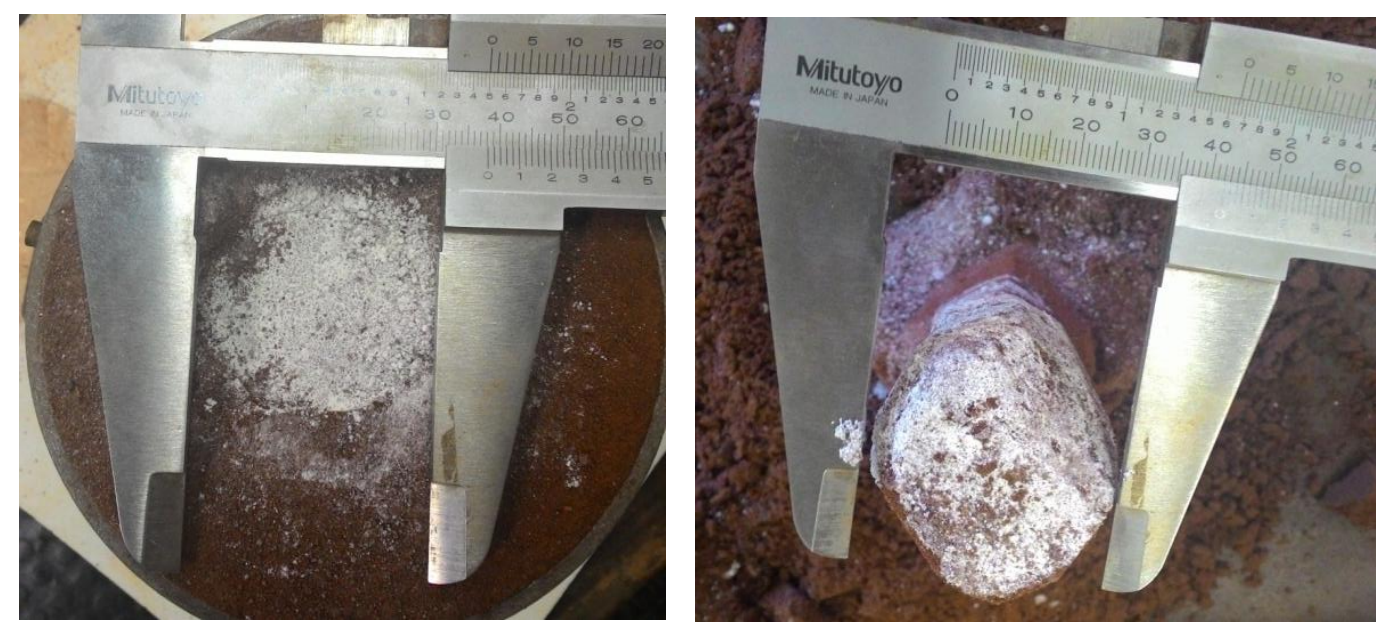

Figura 5.20: Seção transversal da coluna com caulim após sua escarificação.

Tabela 5.10: Dimensões encontradas após escarificação da coluna com caulim.

\begin{tabular}{|c|c|c|c|}
\hline & Inicial & Final & Variação (\%) \\
\hline Diâmetro máximo $(\mathrm{cm})$ & 1,9 & 4,2 & 121,0 \\
\hline Diâmetro mínimo $(\mathrm{cm})$ & 1,9 & 3,2 & 68,4 \\
\hline Profundidade $(\mathrm{cm})$ & 15,0 & 15,4 & 2,7 \\
\hline
\end{tabular}




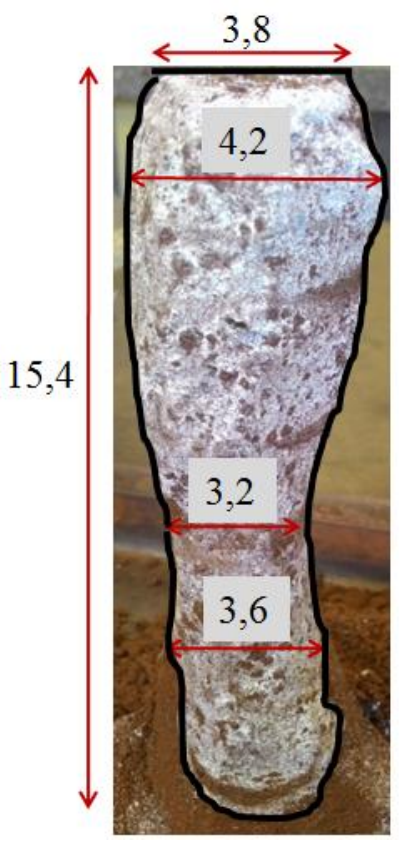

Figura 5.21: Esquema ilustrativo do perfil longitudinal da coluna de caulim executada. Medidas em centímetros.

\subsection{Modelagem em Centrífuga Geotécnica}

Com base nos resultados obtidos dos demais ensaios realizados, foi considerado como o mais representativo do campo o grau de compactação de $75 \%$, com teor de umidade de $10,5 \%$. Assim sendo, todos os ensaios em centrífuga foram modelados com esses parâmetros para a compactação do container. Para as colunas, os parâmetros adotados foram os ótimos, referentes a um grau de compactação de $100 \%$ e um teor de umidade de $13,5 \%$.

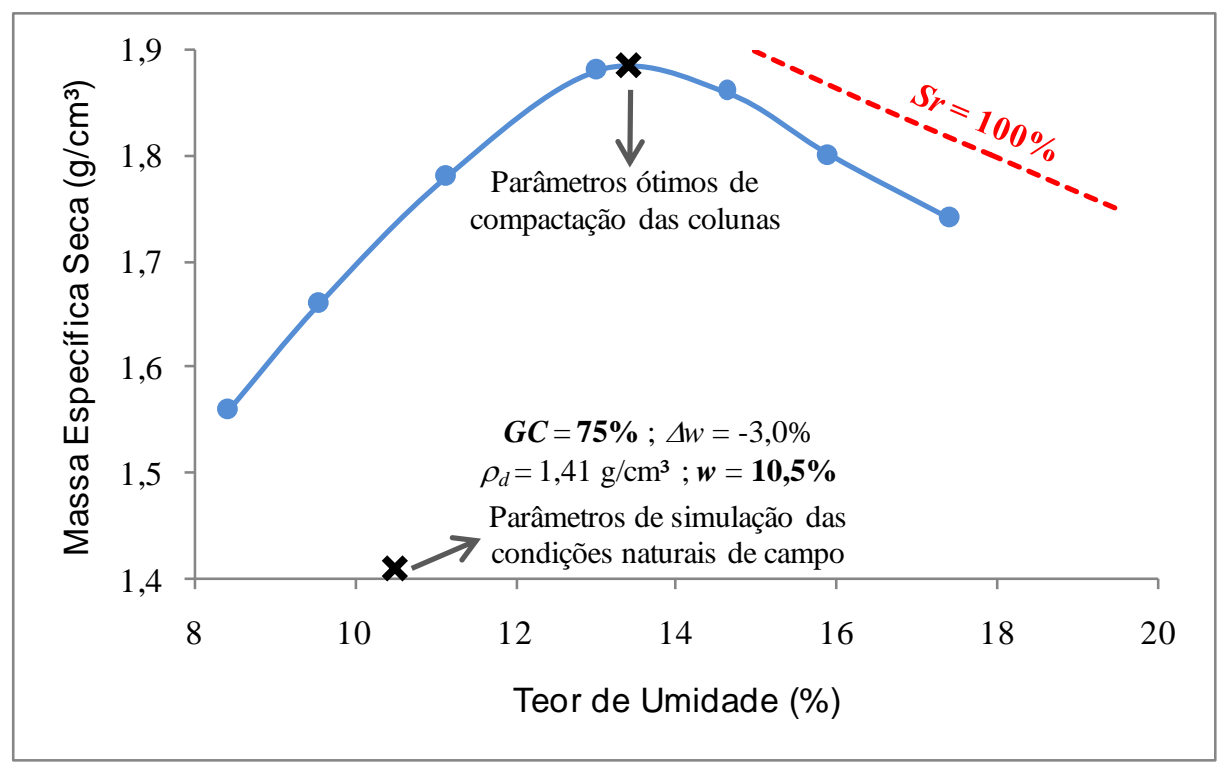

Figura 5.22: Parâmetros de compactação das colunas e do solo natural simulando as condições de campo, de acordo com a curva de Proctor obtida. 
Para as duas primeiras camadas do container adotou-se um grau de compactação de $100 \%$. Isso porque foi considerado que o bulbo de tensões não chegaria a tal profundidade, considerada como indeslocável e que ficaria fixa em todos os ensaios. Além disso, haveria também a simulação de uma camada mais resistente e profunda em campo.

Dessa forma, a compactação do container deu-se através dos seguintes cálculos:

$$
\begin{aligned}
& \text { Camadas } 1 \text { e } 2 \rightarrow \text { Massa de solo }=\rho \cdot V=\rho_{d} \cdot(1+w) \cdot V \\
& =1,00 \cdot 1,88 \cdot(1+0,105) \cdot\left[\left(\pi \cdot 46,4^{2} / 4\right) \cdot 5\right]=17 \cdot 564 g \\
& \begin{aligned}
\text { Camadas } 3 \text { a } 9 & \rightarrow \text { Massa de solo }=\rho \cdot V=\rho_{d} \cdot(1+w) \cdot V \\
& =0,75 \cdot 1,88 \cdot(1+0,105) \cdot\left[\left(\pi \cdot 46,4^{2} / 4\right) \cdot 5\right]=13 \cdot 173 g \\
\text { Camada } 10 \rightarrow & \text { Massa de solo }=\rho \cdot V=\rho_{d} \cdot(1+w) \cdot V \\
& =0,75 \cdot 1,88 \cdot(1+0,105) \cdot\left[\left(\pi \cdot 46,4^{2} / 4\right) \cdot 2,5\right]=6 \cdot 586 g
\end{aligned}
\end{aligned}
$$

Sendo as camadas 1 e 2 fixas (compactadas apenas uma vez, no início dos ensaios) e as camadas 3 a 10 retiradas e re-compactadas a cada ensaio realizado.

\subsubsection{Solo sem Reforço}

Para o solo sem nenhuma coluna de reforço, seguem abaixo os resultados obtidos para os ensaios não inundado (condição natural) e inundado. As curvas tensão $x$ deslocamento apresentadas são todas referentes ao protótipo (com os deslocamentos já corrigidos pela escala $10 g$ do ensaio em centrífuga).

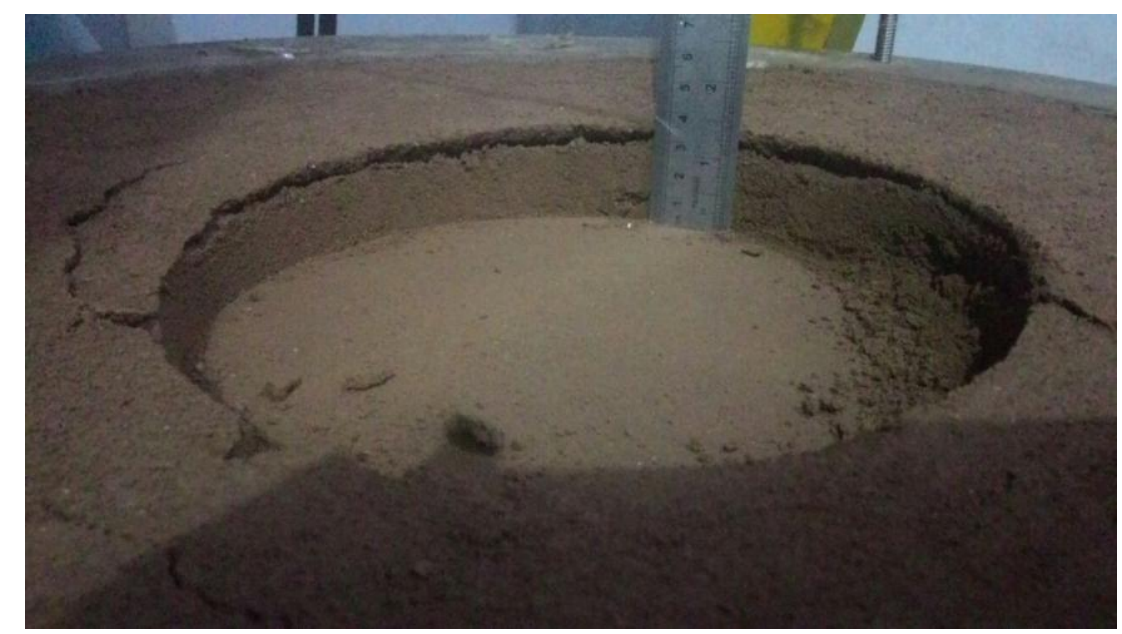

Figura 5.23: Superfície do container após término do ensaio não inundado do solo sem reforço. 


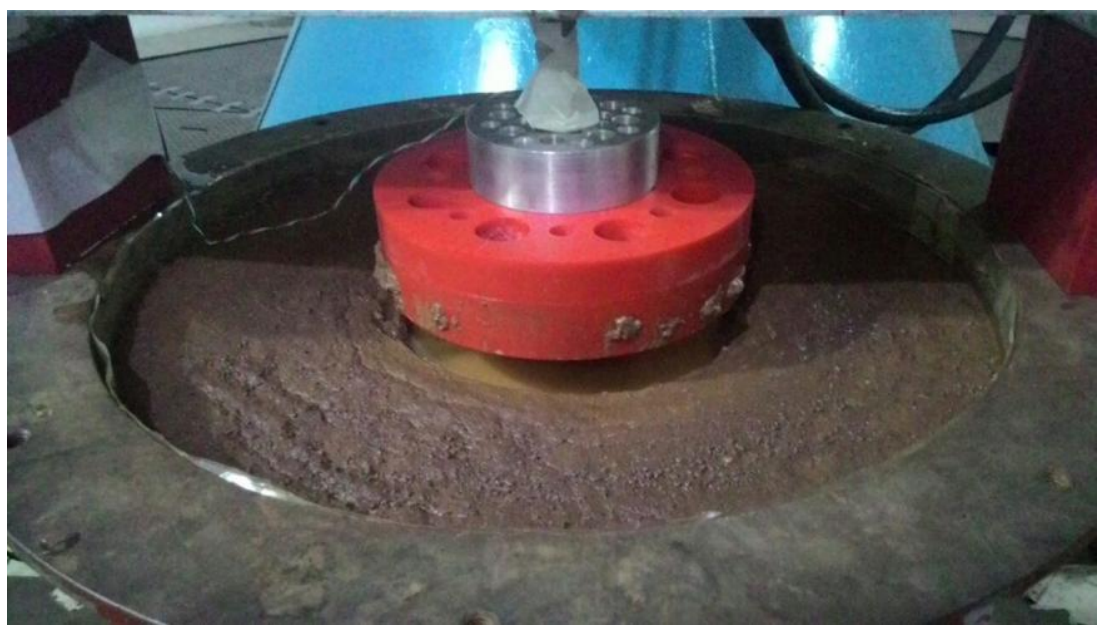

Figura 5.24: Superfície do container após término do ensaio inundado do solo sem reforço.
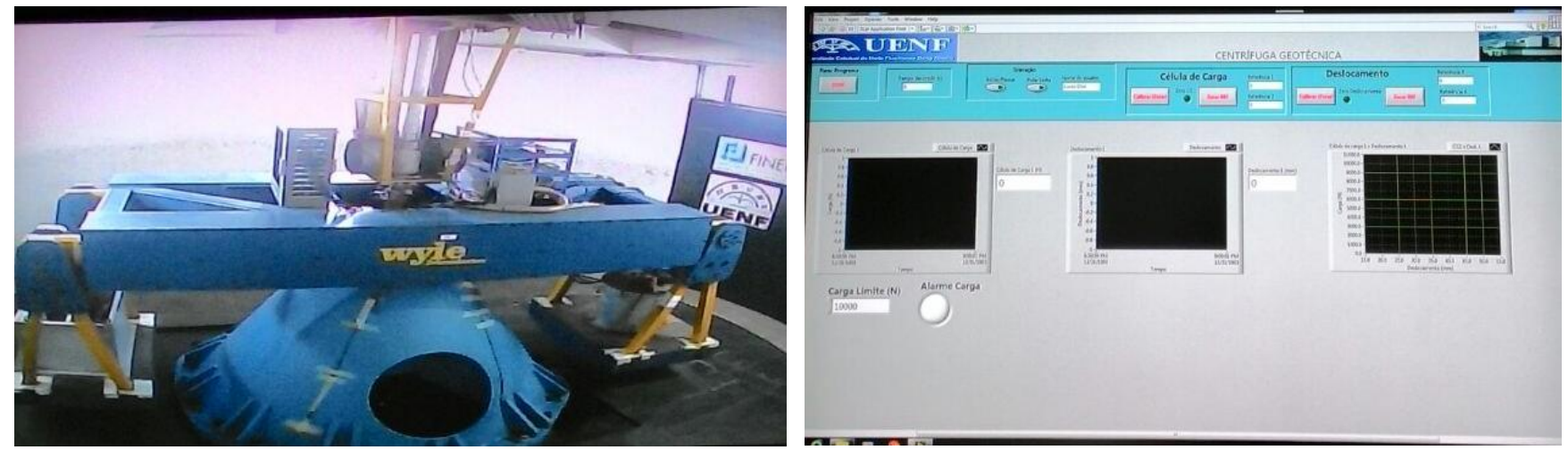

Figura 5.25: Imagem das telas da sala de comando: câmera da centrífuga pronta para realização do ensaio (à esquerda) e programa para aquisição e gravação dos dados requeridos (deslocamento vertical e célula de carga - à direita).

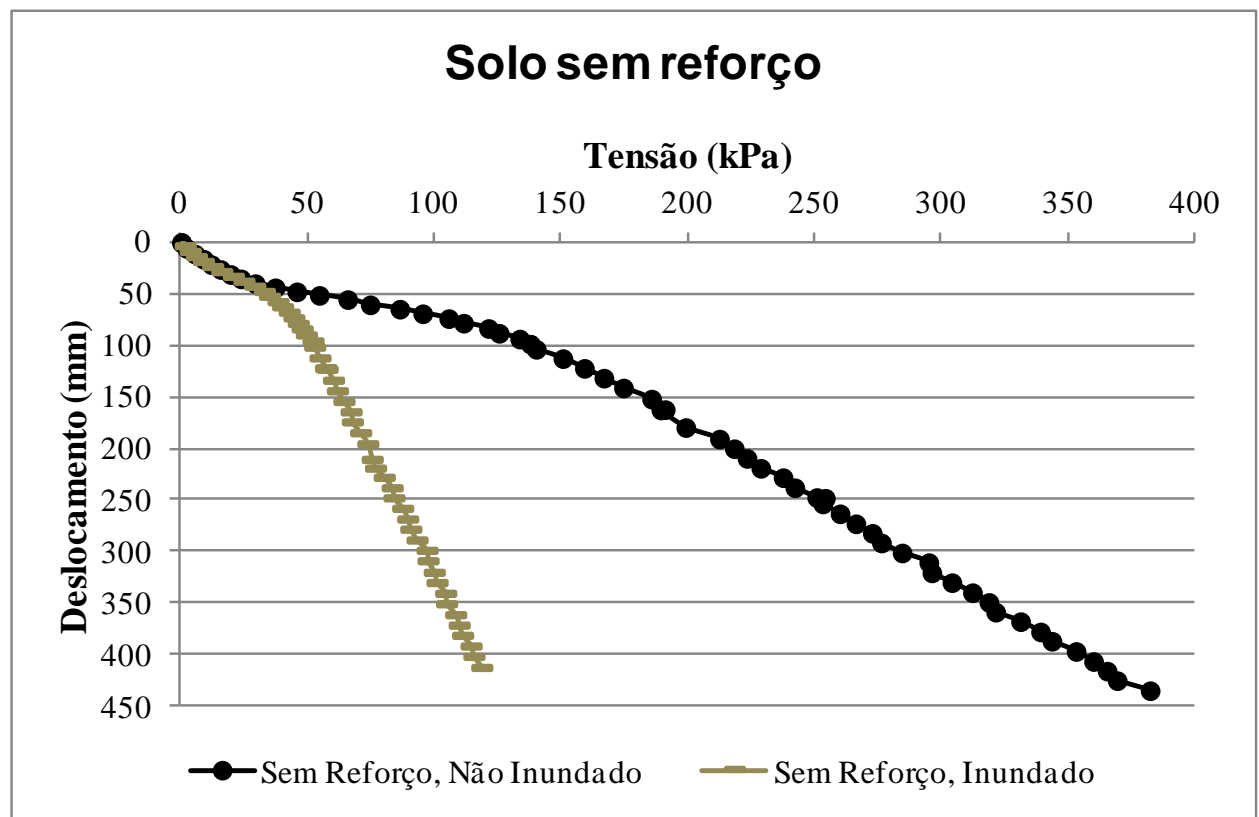

Figura 5.26: Curvas tensão versus deslocamento obtidas para o solo sem reforço (com os valores já corrigidos para o protótipo). 
Para o ensaio do solo sem reforço na condição não inundada foram retiradas algumas amostras indeformadas, com anéis biselados de aço, para obtenção dos índices físicos. Os resultados são ilustrados na Tabela 5.11 a seguir.

Tabela 5.11: Índices físicos obtidos para o ensaio do solo sem reforço na condição não inundada.

\begin{tabular}{|c|ccc|}
\hline Índices Físicos & $\begin{array}{c}\text { Camada 8 } \\
(\mathbf{h}=\mathbf{1 0 0} \mathbf{~ m m})\end{array}$ & $\begin{array}{c}\text { Camada 6 } \\
(\mathbf{h = 2 0 0} \mathbf{~ m m})\end{array}$ & $\begin{array}{c}\text { Resultado } \\
\text { Esperado }\end{array}$ \\
\hline$w(\%)$ & 12,66 & 13,35 & 10,50 \\
$\rho\left(\mathrm{g} / \mathrm{cm}^{3}\right)$ & 1,77 & 1,81 & 1,56 \\
$\rho_{d}\left(\mathrm{~g} / \mathrm{cm}^{3}\right)$ & 1,57 & 1,59 & 1,41 \\
$\rho_{s}\left(\mathrm{~g} / \mathrm{cm}^{3}\right)$ & 2,66 & 2,66 & 2,66 \\
$V\left(\mathrm{~cm}^{3}\right)$ & 168,48 & 174,65 & 168,48 \\
$M_{s}(\mathrm{~g})$ & 264,91 & 278,42 & 237,56 \\
$V_{s}\left(\mathrm{~cm}^{3}\right)$ & 99,74 & 104,83 & 89,44 \\
$V_{v}\left(\mathrm{~cm}^{3}\right)$ & 68,74 & 69,82 & 79,04 \\
$V_{w}\left(\mathrm{~cm}^{3}\right)$ & 33,53 & 37,17 & 24,94 \\
$V_{a r}\left(\mathrm{~cm}^{3}\right)$ & 35,21 & 32,65 & 54,09 \\
$e$ & 0,69 & 0,67 & 0,88 \\
$S_{r}(\%)$ & $48,78 \%$ & $53,24 \%$ & $31,56 \%$ \\
$n$ & 0,41 & 0,40 & 0,47 \\
\hline
\end{tabular}

Para a compactação do container, houve controle rigoroso do teor de umidade do solo e do volume (para que fossem obtidos os parâmetros requeridos com uma boa confiabilidade e repetibilidade entre os ensaios). Assim sendo, esse aumento do teor de umidade pode ser explicado pelo fato de que a força oriunda da aceleração causada pela centrífuga faz com que a água percorra em direção ao fundo do container, aumentando os teores de umidade proporcionalmente è profundidade.

No ensaio sem reforço inundado não foi possível a retirada de amostras indeformadas devido ao elevado teor de umidade da inundação. Além disso, como formou uma lâmina d'água no centro deformado após o ensaio, julgou-se não plausível a retirada de amostra deformada para obtenção do teor de umidade (visto que seria necessário descartar água e mascarar o resultado).

\subsubsection{Malha de colunas com espaçamento $4 d$}

O procedimento de cravação das colunas metálicas foi satisfatório, tal como a estabilidade verificada em todos os furos. O processo de compactação das colunas foi executado 
com controle do volume e, tendo em vista o aumento radial da geometria devido ao processo executivo, foram tomados como base os resultados obtidos do modelo realizado com a coluna com caulim no cilindro de Proctor modificado (expressos na Tabela 5.10 do presente trabalho).

Primeiramente, considerou-se uma média dos diâmetros máximo e mínimo obtidos, adotando um diâmetro de $35 \mathrm{~mm}$. Dessa forma, para obter um grau de compactação de $100 \%$ (massa específica seca equivalente à máxima de $1,88 \mathrm{~g} / \mathrm{cm}^{3}$ ) e com um teor de umidade referente ao ótimo $(13,5 \%)$, foi obtida a seguinte massa por camada:

$$
\begin{aligned}
& \text { Massa de solo por camada }=\rho \cdot V=\rho_{d} \cdot(1+w) \cdot V \\
& \quad=1,88 \cdot(1+0,135) \cdot\left[\left(\pi \cdot 3,5^{2} / 4\right) \cdot 2,5\right]=51,32 g
\end{aligned}
$$

Contudo, a perturbação causada pela cravação simultânea das 7 colunas, juntamente com a dificuldade de execução de um modelo em escala reduzida à $l g$ (montagem do ensaio) e a imposição do aumento radial da coluna no processo de compactação fizeram com que o solo no entorno da coluna começasse a trincar significativamente conforme os golpes para compactação eram aplicados. Dessa foram, tal diâmetro foi considerado até a camada 5 da coluna em questão, ficando as camadas 6 a 8 com um diâmetro adotado de $30 \mathrm{~mm}$ e uma massa por camada equivalente a:

$$
\begin{array}{r}
\text { Massa de solo/camada (camadas } 6 \text { a } 8)=\rho \cdot V=\rho_{d} \cdot(1+w) \cdot V \\
=1,88 \cdot(1+0,135) \cdot\left[\left(\pi \cdot \frac{3,0^{2}}{4}\right) \cdot 2,5\right]=37,71 \mathrm{~g}
\end{array}
$$

Assim sendo, o processo de compactação das colunas pode ser sintetizado na Tabela 5.12 a seguir.

Tabela 5.12: Considerações para o processo de compactação das colunas na modelagem em centrífuga.

\begin{tabular}{|ccc|}
\hline \multirow{3}{*}{ Geral } & $G C(\%)$ & 100,00 \\
& $w(\%)$ & 13,50 \\
& $\rho_{d}\left(\mathrm{~g} / \mathrm{cm}^{3}\right)$ & 1,88 \\
\hline \multirow{4}{*}{ Camadas 1 a 5 } & Diâmetro considerado $(\mathrm{mm})$ & 35 \\
& $V\left(\mathrm{~cm}^{3}\right)$ & 24,05 \\
& $\rho\left(\mathrm{g} / \mathrm{cm}^{3}\right)$ & 2,13 \\
& $M_{\text {solo }}(\mathrm{g})$ & 51,32 \\
\hline \multirow{3}{*}{ Camadas 6 a 8 } & Diâmetro considerado $(\mathrm{mm})$ & 30 \\
& $V\left(\mathrm{~cm}^{3}\right)$ & 17,67 \\
& $\rho\left(\mathrm{g} / \mathrm{cm}^{3}\right)$ & 2,13 \\
& $M_{\text {solo }}(\mathrm{g})$ & 37,71 \\
\hline
\end{tabular}




\subsubsection{Ensaio com 7 colunas}

Para a malha triangular com espaçamento $4 d$ e com as colunas dispostas apenas na região de projeção da placa de atuação (ensaio com 7 colunas) foi testada apenas a condição não inundada, cujos resultados são expressos a seguir.

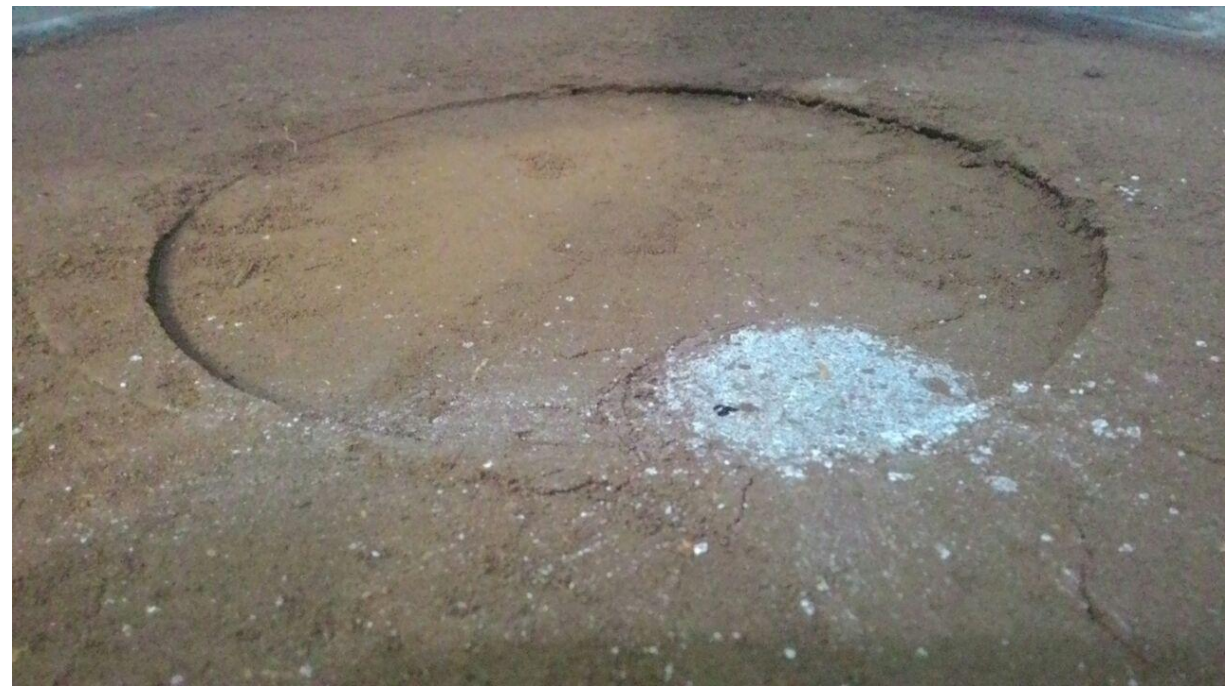

Figura 5.27: Resultado da deformação sofrida pelo solo após realização do ensaio de espaçamento $4 d$ com 7 colunas.
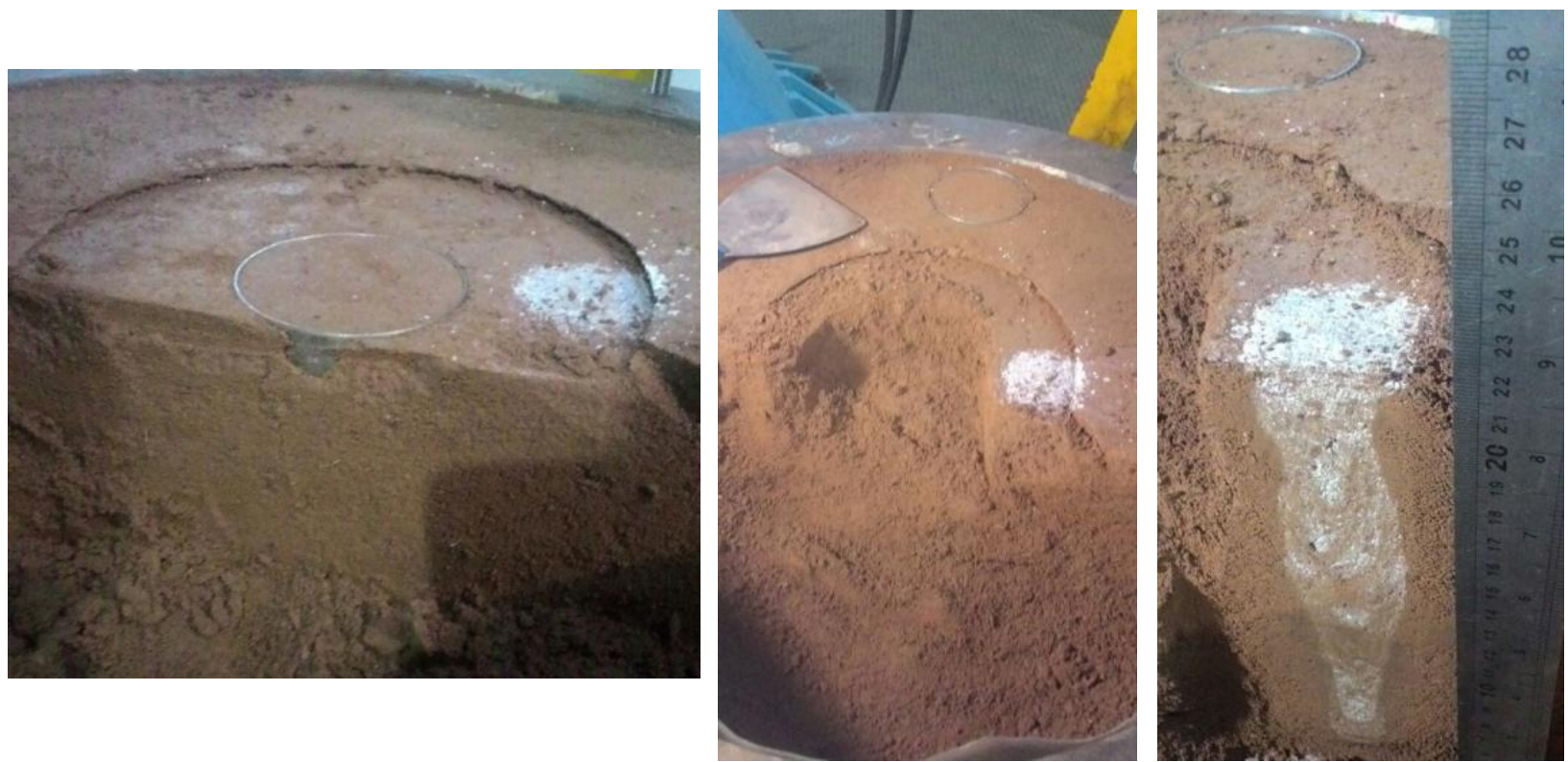

Figura 5.28: Escarificação do container para retirada de amostras indeformadas e noção da geometria da coluna compactada com mistura de solo e caulim. 

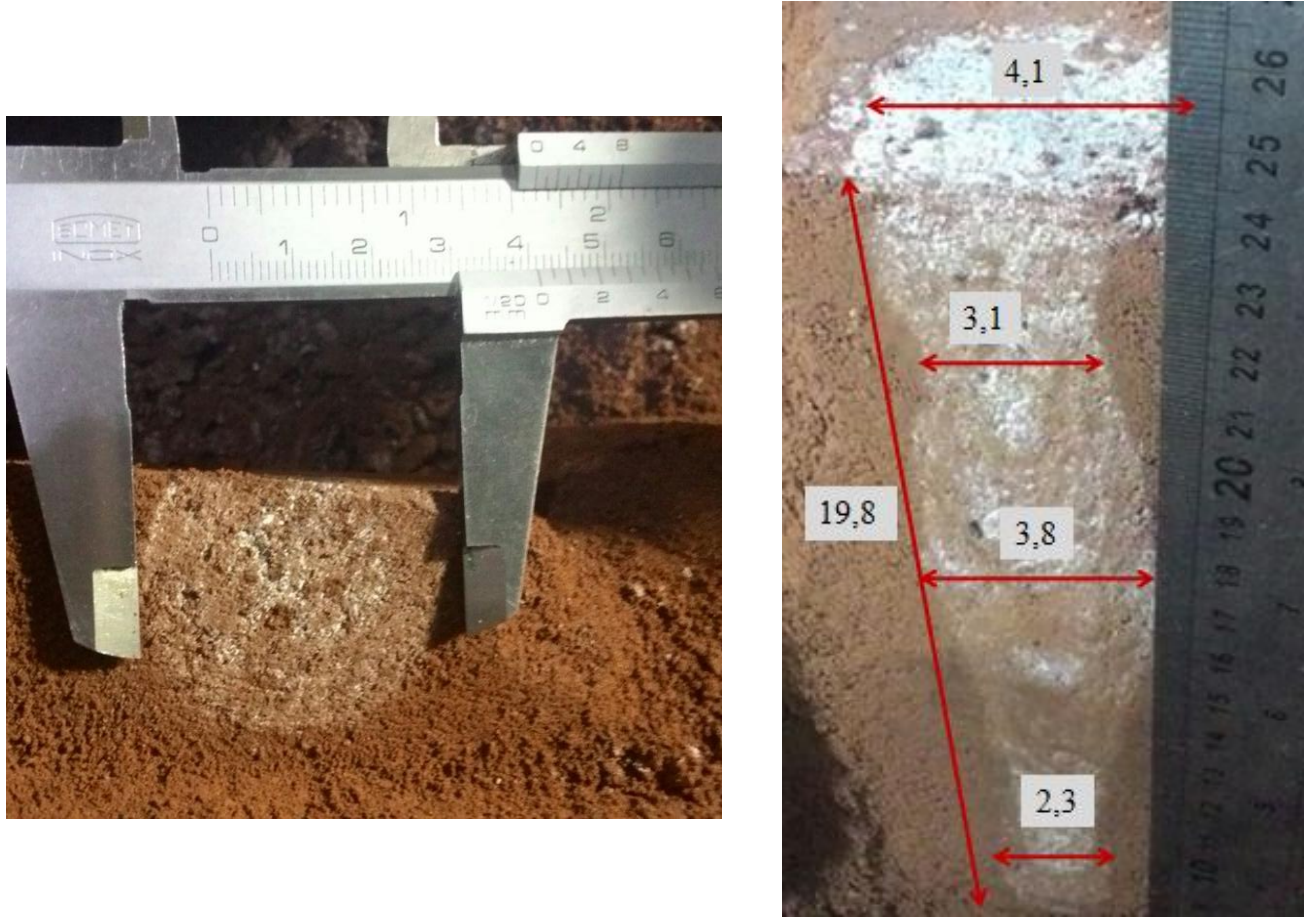

Figura 5.29: Dimensões da coluna com caulim retiradas após o término do ensaio. Medidas em centímetros.

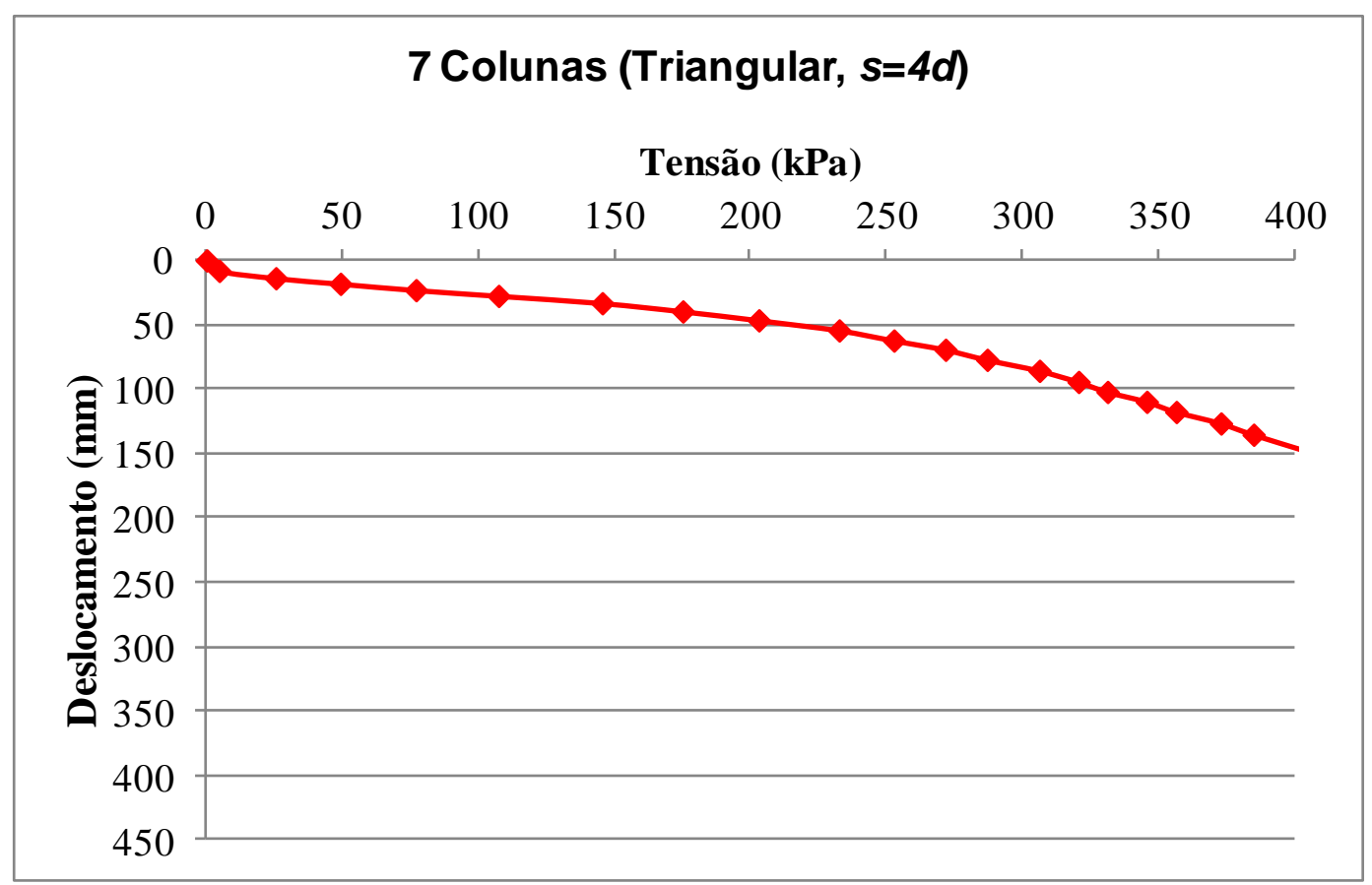

Figura 5.30: Resultado da curva tensão $x$ deslocamento obtida após realização do ensaio com 7 colunas (com os valores já corrigidos para o protótipo). 
Tabela 5.13: Resultados obtidos das amostras indeformadas retiradas do solo do container após término do ensaio com 7 colunas.

\begin{tabular}{|c|c|cc|cc|}
\hline \multicolumn{5}{|c|}{ Solo do Container } \\
\hline \multirow{2}{*}{ Índices } & \multirow{2}{*}{$\begin{array}{c}\text { Resultados } \\
\text { Esicos }\end{array}$} & $\begin{array}{c}\text { Amostra retirada da superfície do } \\
\text { container em sua periferia }\end{array}$ & $\begin{array}{c}\text { Amostra retirada da superfície do } \\
\text { container em seu centro }\end{array}$ \\
\cline { 3 - 6 } & & Obtido & Diferença & Obtido & Diferença \\
\hline$w(\%)$ & $10,50 \%$ & $9,84 \%$ & $-6,3 \%$ & $11,14 \%$ & $6,1 \%$ \\
$\rho\left(\mathrm{g} / \mathrm{cm}^{3}\right)$ & 1,56 & 1,61 & $3,5 \%$ & 1,86 & $19,4 \%$ \\
$\rho_{d}\left(\mathrm{~g} / \mathrm{cm}^{3}\right)$ & 1,41 & 1,47 & $4,1 \%$ & 1,67 & $18,7 \%$ \\
$G C$ & $75 \%$ & $78 \%$ & $4,1 \%$ & $89 \%$ & $18,7 \%$ \\
$\rho_{s}\left(\mathrm{~g} / \mathrm{cm}^{3}\right)$ & 2,66 & 2,66 & $0,0 \%$ & 2,66 & $0,0 \%$ \\
$V\left(\mathrm{~cm}^{3}\right)$ & 168,48 & 168,48 & $0,0 \%$ & 174,65 & $3,7 \%$ \\
$M_{s}(\mathrm{~g})$ & 237,56 & 247,28 & $4,1 \%$ & 292,23 & $23,0 \%$ \\
$V_{s}\left(\mathrm{~cm}^{3}\right)$ & 89,44 & 93,10 & $4,1 \%$ & 110,03 & $23,0 \%$ \\
$V_{v}\left(\mathrm{~cm}^{3}\right)$ & 79,04 & 75,37 & $-4,6 \%$ & 64,62 & $-18,2 \%$ \\
$V_{w}\left(\mathrm{~cm}^{3}\right)$ & 24,94 & 24,34 & $-2,4 \%$ & 32,55 & $30,5 \%$ \\
$V_{a r}\left(\mathrm{~cm}^{3}\right)$ & 54,09 & 51,04 & $-5,7 \%$ & 32,07 & $-40,7 \%$ \\
$e$ & 0,88 & 0,81 & $-8,4 \%$ & 0,59 & $-33,5 \%$ \\
$S_{r}(\%)$ & $31,56 \%$ & $32,29 \%$ & $2,3 \%$ & $50,38 \%$ & $59,6 \%$ \\
$N$ & 0,47 & 0,45 & $-4,6 \%$ & 0,37 & $-21,1 \%$ \\
\hline
\end{tabular}

Tabela 5.14: Resultados obtidos das amostras indeformadas retiradas das colunas após término do ensaio com 7 colunas.

\begin{tabular}{|c|c|c|c|c|}
\hline \multicolumn{5}{|c|}{ Colunas } \\
\hline \multirow{2}{*}{ Índices Físicos } & $\begin{array}{c}\text { Resultado } \\
\text { Esperado }\end{array}$ & $\begin{array}{c}\text { Topo coluna com } \\
\text { caulim }\end{array}$ & $\begin{array}{c}\text { Meio coluna com } \\
\text { Caulim }\end{array}$ & $\begin{array}{c}\text { Topo coluna } \\
\text { Central }\end{array}$ \\
\cline { 3 - 5 }$w(\%)$ & $13,50 \%$ & $13,00 \%$ & $14,02 \%$ & $11,33 \%$ \\
$\rho\left(\mathrm{g} / \mathrm{cm}^{3}\right)$ & 2,1338 & 2,04 & 2,10 & 2,07 \\
$\rho_{d}\left(\mathrm{~g}^{3} \mathrm{~cm}^{3}\right)$ & 1,88 & 1,80 & 1,85 & 1,86 \\
$G C$ & $100 \%$ & $96 \%$ & $98 \%$ & $99 \%$ \\
$\rho_{s}\left(\mathrm{~g} / \mathrm{cm}^{3}\right)$ & 2,656 & 2,656 & 2,656 & 2,656 \\
$V\left(\mathrm{~cm}^{3}\right)$ & 8,87 & 8,87 & 8,87 & 8,87 \\
$M_{s}(\mathrm{~g})$ & 16,68 & 15,99 & 16,37 & 16,49 \\
$V_{s}\left(\mathrm{~cm}^{3}\right)$ & 6,28 & 6,02 & 6,17 & 6,21 \\
$V_{v}\left(\mathrm{~cm}^{3}\right)$ & 2,59 & 2,85 & 2,71 & 2,66 \\
$V_{w}\left(\mathrm{~cm}^{3}\right)$ & 2,25 & 2,08 & 2,30 & 1,87 \\
$V_{a r}\left(\mathrm{~cm}^{3}\right)$ & 0,34 & 0,77 & 0,41 & 0,80 \\
$e$ & 0,41 & 0,47 & 0,44 & 0,43 \\
$S_{r}(\%)$ & $86,87 \%$ & $72,87 \%$ & $84,76 \%$ & $70,13 \%$ \\
$n$ & 0,29 & 0,32 & 0,31 & 0,30 \\
\hline
\end{tabular}




\subsubsection{Ensaio com 13 colunas}

Para a malha triangular com espaçamento $4 d$ e com as colunas dispostas tanto na região de projeção da placa de atuação quanto em seu entorno (ensaio com 13 colunas) foram testadas as condições não inundada e inundada, cujos resultados são expressos a seguir.

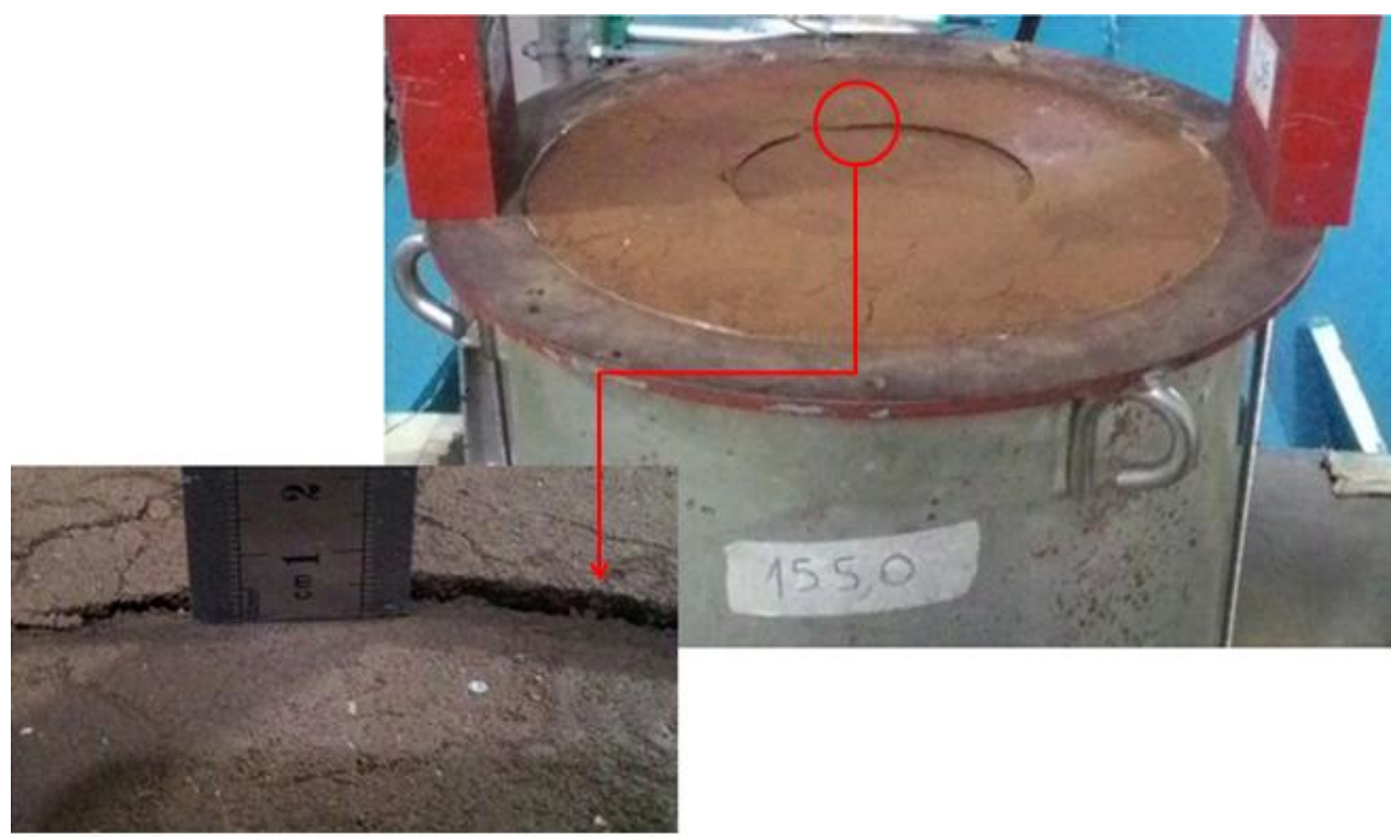

Figura 5.31: Container após a realização do ensaio de espaçamento $4 d$ com 13 colunas na condição não inundada (primeiro voo).

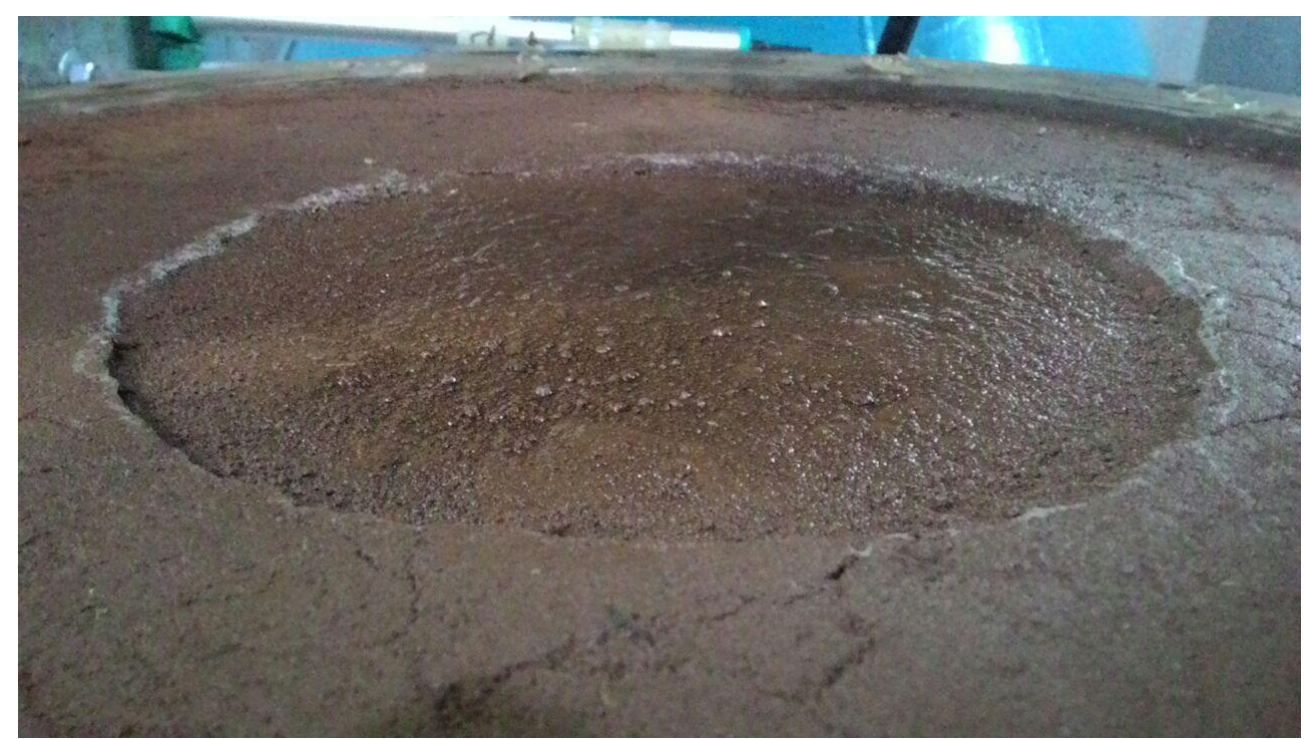

Figura 5.32: Container após primeiro voo, sendo inundado para segundo voo (realização do ensaio inundado). 

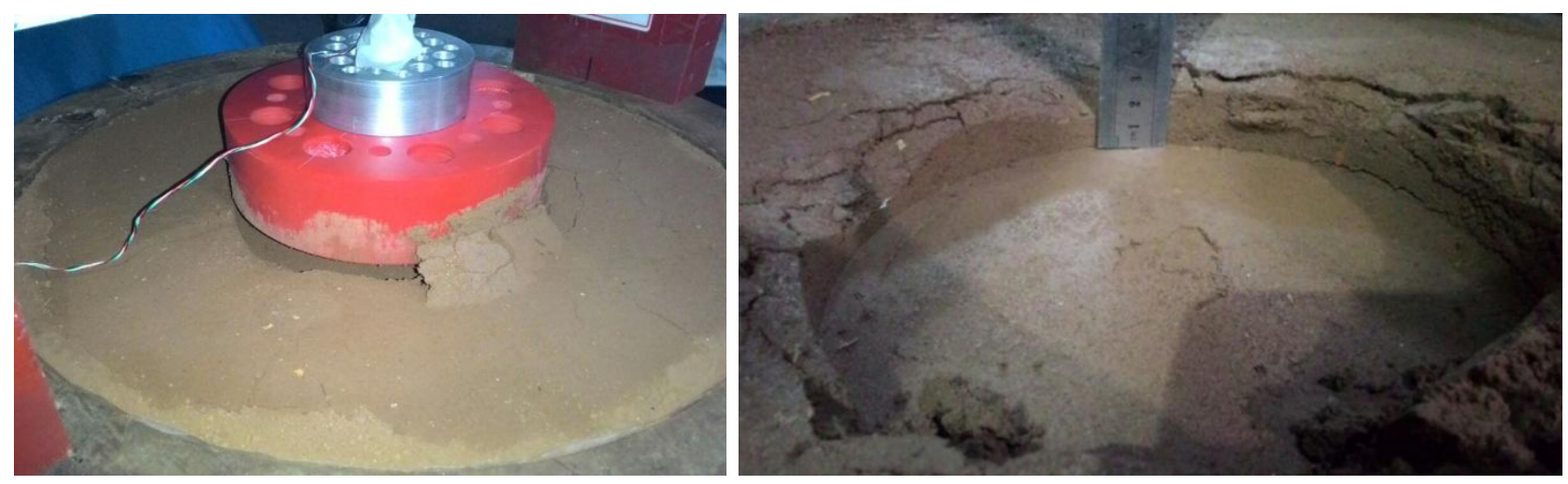

Figura 5.33: Container após a realização do ensaio com 13 colunas na condição inundada (segundo vôo).
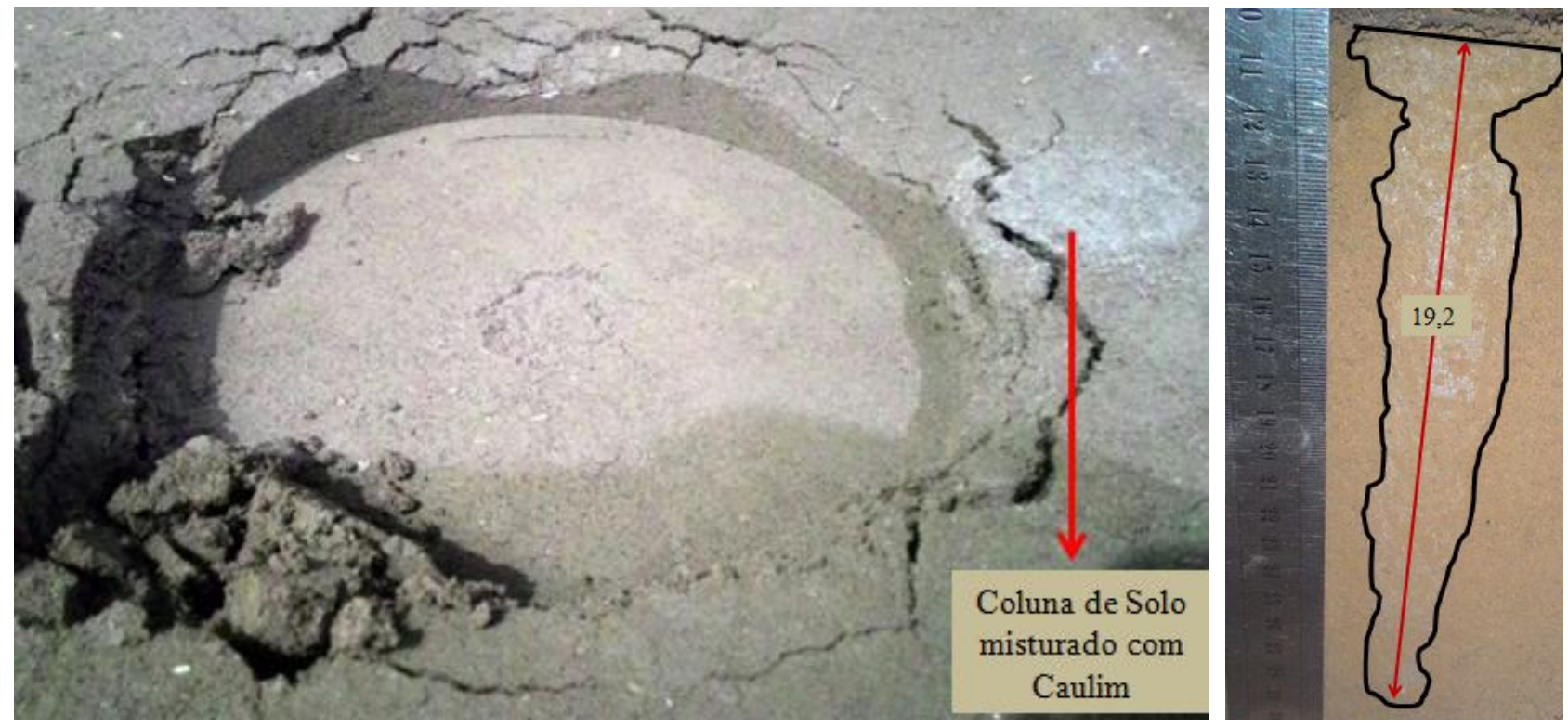

Figura 5.34: Coluna de solo com caulim após realização do ensaio inundado com 13 colunas. Medida em cm.

Pela limitação da quantidade de solo transportado à centrífuga geotécnica, bem como do ensaio demandar dias para sua execução, optou-se por reutilizar o mesmo container de 13 colunas (após ensaio não inundado) para proceder a inundação e obter os resultados inundados. Como foi um reensaio, o solo durante o seu primeiro voo (ensaio não inundado) já havia sofrido dois ciclos de carregamento e descarregamento, necessários de serem levados em conta para exibição dos resultados na condição inundada.

Todos os ensaios sofreram ciclos de carregamento e descarregamento. Como os deslocamentos já eram demasiadamente excessivos julgou-se dispensável a apresentação da curva a partir do primeiro descarregamento sofrido para os demais ensaios. Para o container com 13 colunas, que foi reensaiado na condição inundada, os ciclos sofridos em seu primeiro voo encontram-se ilustrados a seguir. 


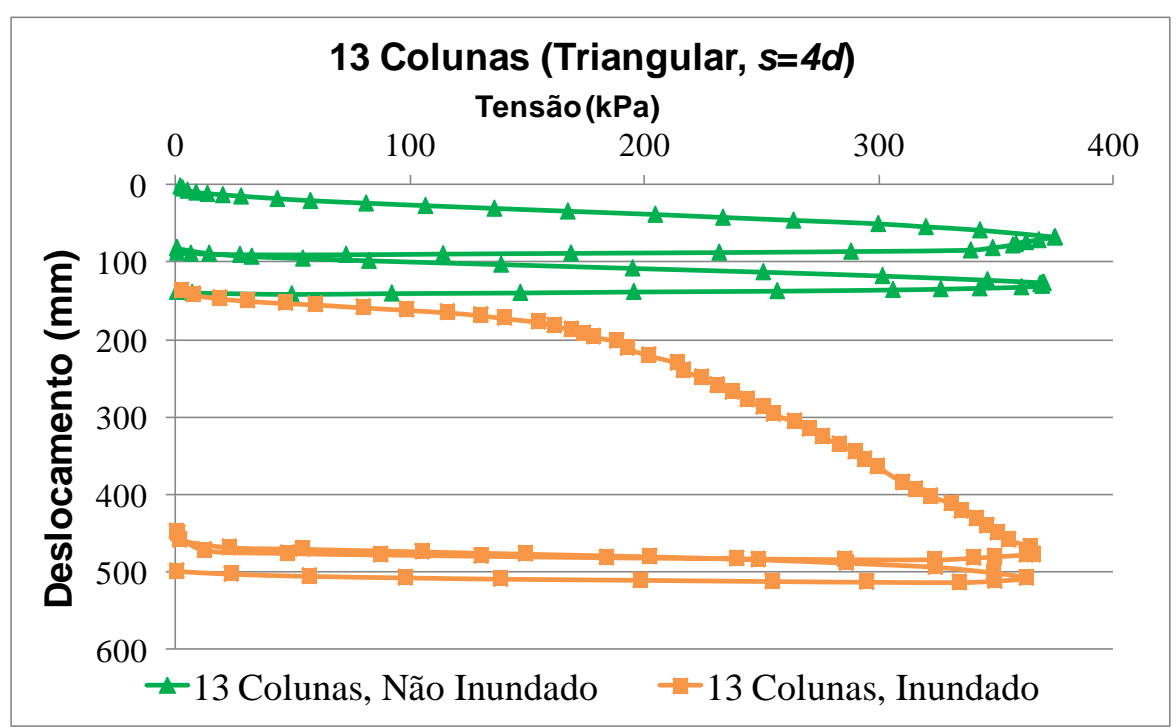

Figura 5.35: Resultados da curva tensão $x$ deslocamento obtida após realização do ensaio de 13 colunas não inundado (primeiro voo, com ciclos de carregamento e descarregamento) e posteriormente reensaiado na condição inundada (mesmo container em um segundo voo).

Contudo, das demais curvas obtidas, verifica-se um comportamento similar entre elas para o trecho do descarregamento que não é verificado para essa apresentada na Figura 5.35. Isso porque o solo continua deslocando quando começa a ser descarregado (o que não é verificado na prática e foge da normalidade). Dessa forma, seria plausível um ajuste da curva para que o ensaio de 13 colunas não inundado seguisse o mesmo comportamento (esperado) dos outros ensaios e dessa forma a origem do ensaio não inundado estaria possivelmente deslocada no eixo das ordenadas. Para anular tal incerteza a também possibilitar a comparação da curva inundada obtida com as demais curvas dos outros ensaios, o eixo do ensaio de 13 colunas inundado foi transferido para coincidir com o eixo do sistema cartesiano, conforme exposto a seguir.

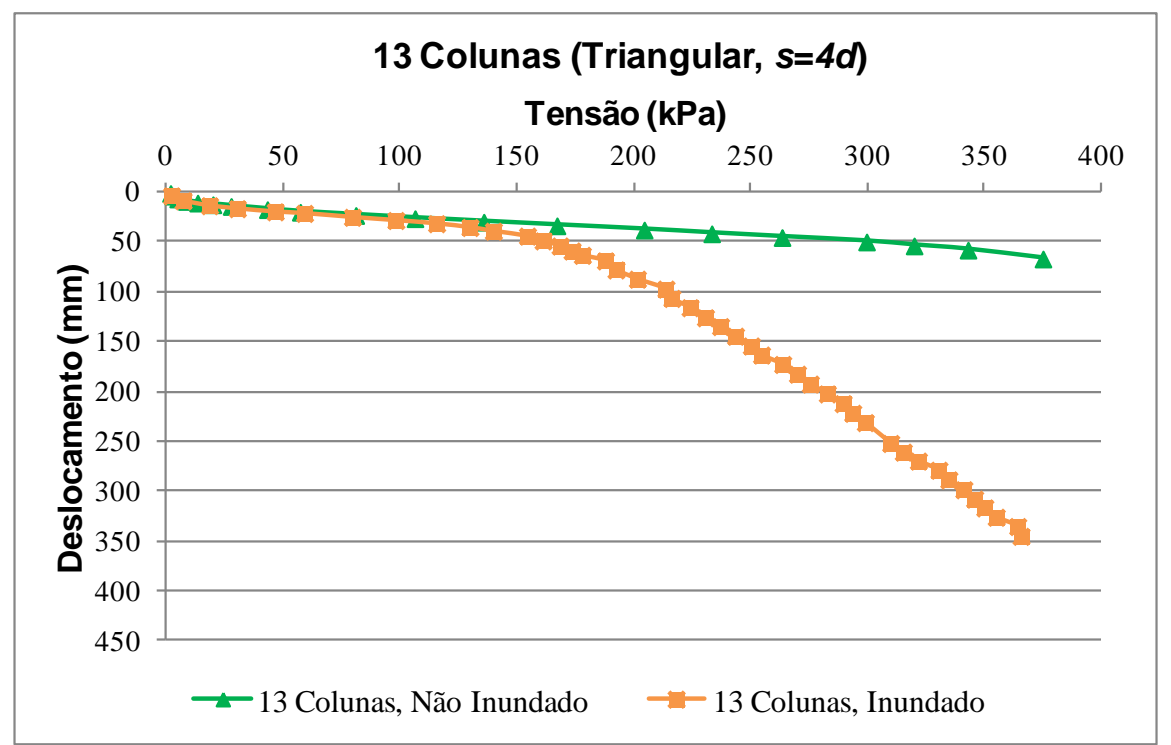

Figura 5.36: Resultado da curva tensão $x$ deslocamento obtida após realização dos ensaios com 13 colunas (não inundado e inundado, com os valores já corrigidos para o protótipo) 
Tabela 5.15: Índices físicos calculados a partir de diversas amostras indeformadas retiradas das colunas após escarificação do ensaio com 13 colunas.

\begin{tabular}{|c|c|c|c|c|c|}
\hline \multicolumn{6}{|c|}{ Colunas } \\
\hline Índices Físicos & $\begin{array}{c}\text { Resultados } \\
\text { Esperados }\end{array}$ & $\begin{array}{c}\text { Topo Coluna } \\
\text { Central }\end{array}$ & $\begin{array}{c}\text { Meio Coluna } \\
\text { Central }\end{array}$ & $\begin{array}{c}\text { Base Coluna } \\
\text { Central }\end{array}$ & $\begin{array}{c}\text { Topo Coluna } \\
\text { Periférica }\end{array}$ \\
\hline$w(\%)$ & $13,5 \%$ & $13,9 \%$ & $12,69 \%$ & $12,65 \%$ & $9,98 \%$ \\
$\rho\left(\mathrm{g} / \mathrm{cm}^{3}\right)$ & 2,13 & 1,96 & 2,01 & 2,11 & 2,11 \\
$\rho_{d}\left(\mathrm{~g}^{\mathrm{c}} \mathrm{cm}^{3}\right)$ & 1,88 & 1,72 & 1,79 & 1,87 & 1,92 \\
$\rho_{s}\left(\mathrm{~g}^{\mathrm{c}} \mathrm{cm}^{3}\right)$ & 2,66 & 2,66 & 2,66 & 2,66 & 2,66 \\
$V\left(\mathrm{~cm}^{3}\right)$ & 168,5 & 168,5 & 9,73 & 8,87 & 8,87 \\
$M_{s}(\mathrm{~g})$ & 316,7 & 289,6 & 17,4 & 16,60 & 17,05 \\
$V_{s}\left(\mathrm{~cm}^{3}\right)$ & 119,3 & 109,02 & 6,54 & 6,25 & 6,42 \\
$V_{v}\left(\mathrm{~cm}^{3}\right)$ & 49,2 & 59,5 & 3,19 & 2,62 & 2,45 \\
$V_{w}\left(\mathrm{~cm}^{3}\right)$ & 42,8 & 40,3 & 2,20 & 2,10 & 1,70 \\
$V_{a r}\left(\mathrm{~cm}^{3}\right)$ & 6,5 & 19,2 & 0,98 & 0,52 & 0,75 \\
$e$ & 0,41 & 0,55 & 0,49 & 0,42 & 0,38 \\
$S_{r}(\%)$ & $86,9 \%$ & $67,8 \%$ & $69,2 \%$ & $80,1 \%$ & $69,3 \%$ \\
$n$ & 0,29 & 0,35 & 0,33 & 0,30 & 0,28 \\
\hline
\end{tabular}

Para a amostragem do solo do container, a tentativa foi de amostrar a uma maior profundidade, abaixo das colunas de reforço, visando uma menor alteração do teor de umidade e menor perturbação devido ao voo.

Tabela 5.16: Índices físicos calculados a partir de amostra indeformada retirada do container a uma profundidade de $210 \mathrm{~mm}$ após escarificação (ensaio com 13 colunas).

\begin{tabular}{|c|c|c|c|}
\hline \multicolumn{4}{|c|}{ Solo Container } \\
\hline Índices Físicos & $\begin{array}{c}\text { Resultados } \\
\text { Esperados }\end{array}$ & $\begin{array}{c}\text { Amostra à } \\
\text { profundidade } \\
\text { h=210 mm }\end{array}$ & Diferença \\
\hline$w(\%)$ & $10,50 \%$ & $12,82 \%$ & $22,14 \%$ \\
$\rho\left(\mathrm{g} / \mathrm{cm}^{3}\right)$ & 1,56 & 1,75 & $12,36 \%$ \\
$\rho_{d}\left(\mathrm{~g} / \mathrm{cm}^{3}\right)$ & 1,41 & 1,51 & $7,02 \%$ \\
$\rho_{s}\left(\mathrm{~g}_{\mathrm{cm}}\right)$ & 2,66 & 2,66 & - \\
$V\left(\mathrm{~cm}^{3}\right)$ & 8,85 & 8,85 & - \\
$M_{s}(\mathrm{~g})$ & 12,48 & 13,35 & $7,02 \%$ \\
$V_{s}\left(\mathrm{~cm}^{3}\right)$ & 4,70 & 5,03 & $7,02 \%$ \\
$V_{v}\left(\mathrm{~cm}^{3}\right)$ & 4,15 & 3,82 & $-7,94 \%$ \\
$V_{w}\left(\mathrm{~cm}^{3}\right)$ & 1,31 & 1,71 & $30,71 \%$ \\
$V_{a r}\left(\mathrm{~cm}^{3}\right)$ & 2,84 & 2,11 & $-25,76 \%$ \\
$E$ & 0,88 & 0,76 & $-13,98 \%$ \\
$S_{r}(\%)$ & $31,56 \%$ & $44,81 \%$ & $41,98 \%$ \\
$N$ & 0,47 & 0,43 & $-7,94 \%$ \\
\hline
\end{tabular}




\subsubsection{Malha de colunas com espaçamento 5d}

Após a cravação das quatro colunas do container compactado, foi verificado o surgimento de trincas unindo os furos das colunas em maior quantidade do que presenciado nos demais ensaios. Uma possível explicação para essa situação é a de que, pelo espaçamento entre eixos ser maior, não houve uma significante melhoria do solo entre as colunas pelo processo de cravação (não houve uma significativa diminuição do índice de vazios), possibilitando que o solo, ainda "não reforçado", trincasse.

Para esse ensaio, foi testada apenas a condição não inundada, cujos resultados são apresentados abaixo.
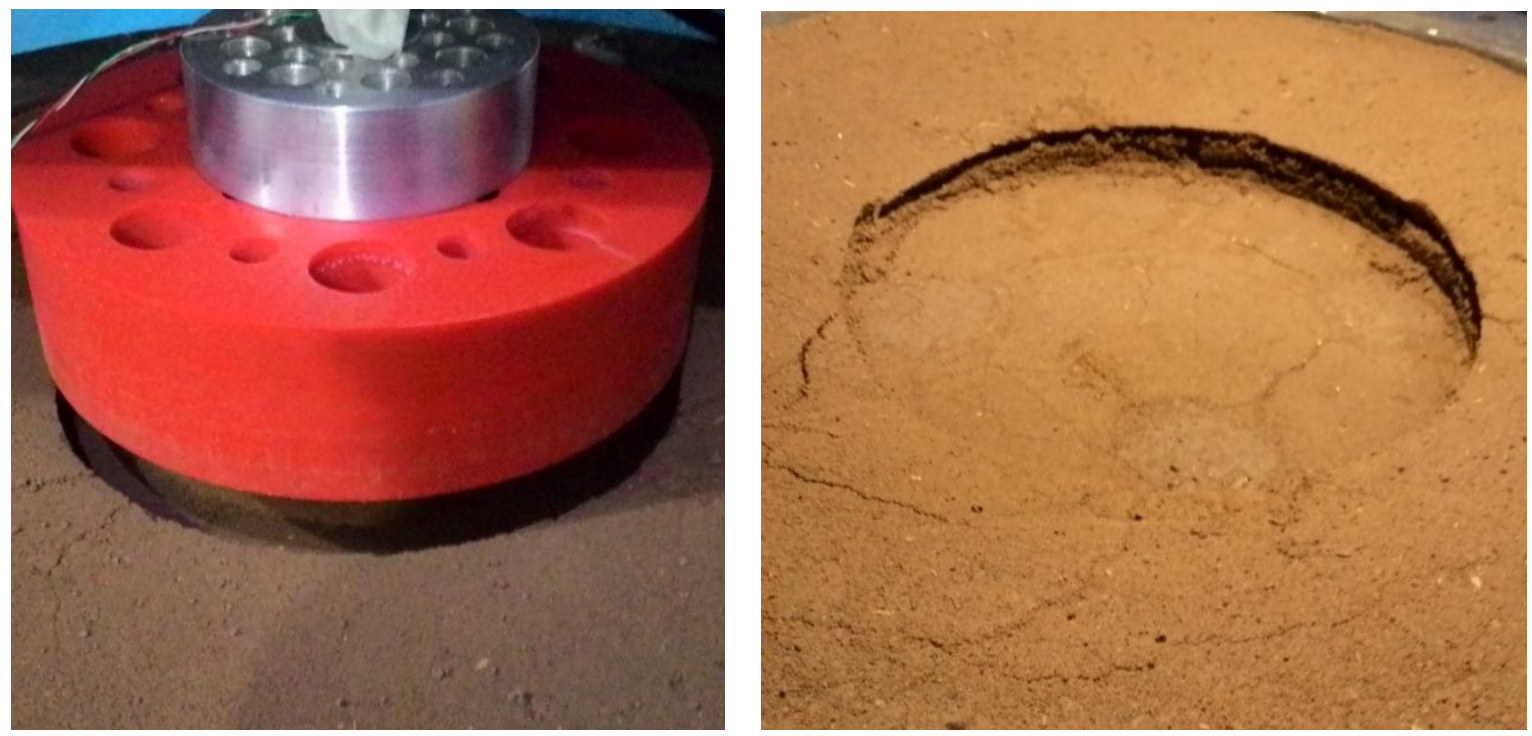

Figura 5.37: Container após realização do ensaio de espaçamento $5 d$ com 4 colunas.

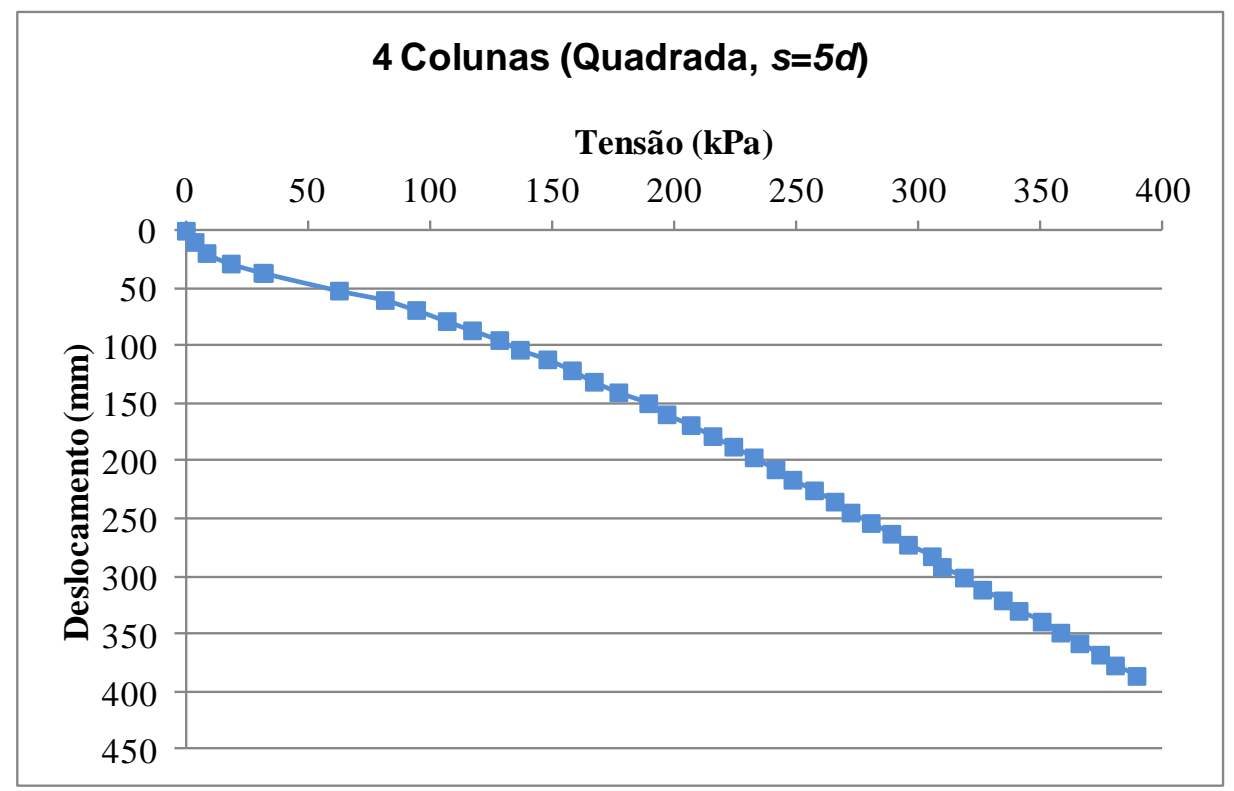

Figura 5.38: Resultado da curva tensão $x$ deslocamento obtida com a realização do ensaio com 4 colunas de reforço (com os valores já corrigidos para o protótipo). 
Por fim, para melhor entendimento do ocorrido e comparação entre todos os resultados apresentados, segue ilustrado na Figura 5.39 abaixo a sobreposição das curvas tensão versus deslocamento obtidas ao longo dos seis ensaios executados.

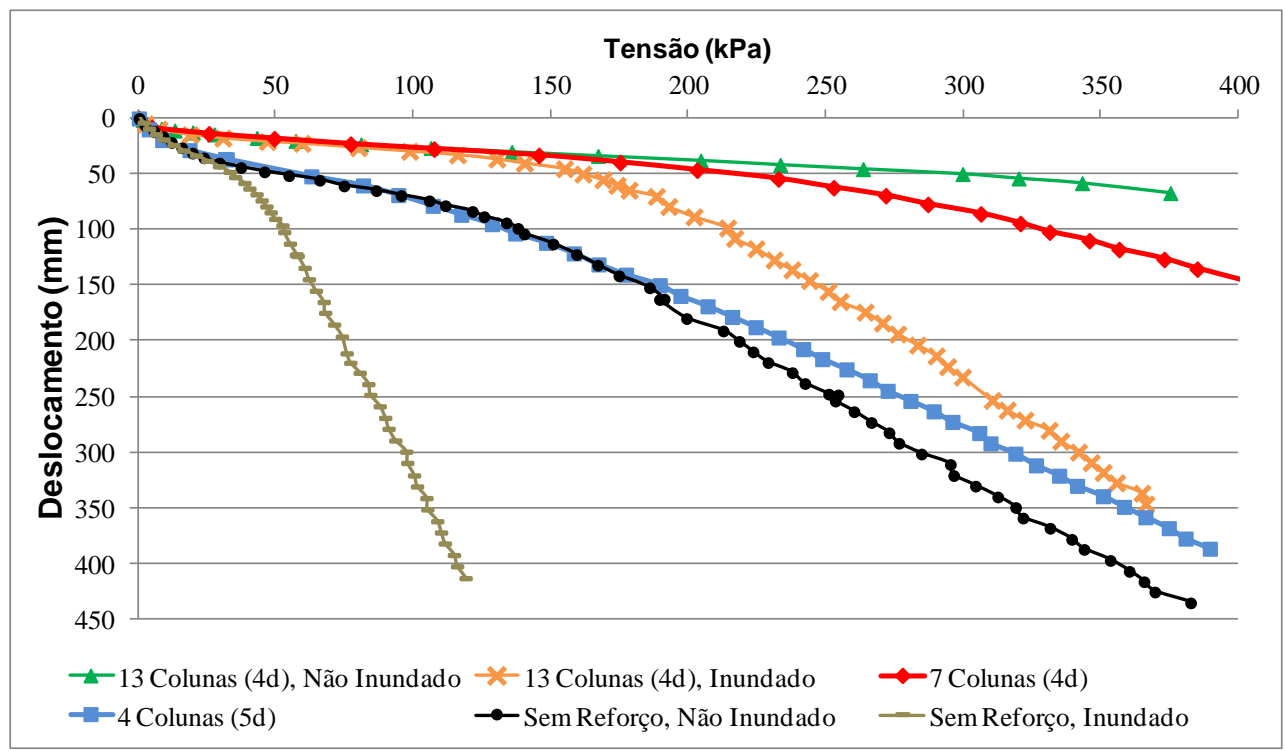

Figura 5.39: Compilação das curvas tensão versus deslocamento obtidas ao longo de todos os ensaios realizados em centrífuga geotécnica.

Dessa sobreposição de informações é possível analisar que o reforço utilizando-se colunas de solo laterítico compactado é extremamente benéfico ao solo colapsível estudado. No entanto, para ocorrer estes benefícios, é necessário uma malha de espaçamento igual ou menor a $4 d$, visto que no caso de espaçamento $5 d$ observou-se alguma melhoria no comportamento carga-recalque apenas após grandes recalques da fundação (maiores que $15 \mathrm{~cm}$ ). Além disso, o efeito da inundação no caso da malha de colunas com espaçamento $4 d$ é muito menos significante do que no caso do solo sem reforço, fato que mostra que esta técnica pode ser também eficiente para reduzir os recalques de colapso neste tipo de solo estudado.

Comparando-se as malhas de $4 d$ e $5 d$ não é possível identificar se tamanha discrepância entre os resultados deve-se em maior parte devido à diferença entre os espaçamentos, à quantidade de colunas compactadas ou à diferença entre as geometrias das malhas. Diversos são os fatores que podem culminar nessa discrepância dos resultados presenciada, em pesos distintos que não são possíveis de serem aferidos. Para a malha de espaçamento $5 d$, a melhoria do solo em questão é praticamente desprezível, sendo muito pouco reforçado e para tensões mais elevadas apenas.

A viabilidade dessa técnica de reforço reside na possibilidade da adoção de fundações diretas em solo colapsível, as quais geralmente são solicitadas por tensões mais baixas (na 
ordem de 150 a $200 \mathrm{kPa}$ ). Para essa faixa de tensão, o solo reforçado, mesmo quando inundado, apresenta deslocamentos extremamente inferiores ao solo sem reforço inundado. O solo sem reforço, para uma tensão de $100 \mathrm{kPa}$, apresentou um recalque de $38 \mathrm{~mm}$, ao passo que para a mesma tensão, o solo reforçado apresentou recalques de 4mm (cerca de 10\%).

Outra importante análise a ser feita refere-se ao fato de que, até tensões de aproximadamente $150 \mathrm{kPa}$, todas as curvas dos ensaios com a malha de espaçamento $4 d$ estão praticamente coincidentes. O aumento na quantidade de colunas de 7 para 13 não foi tão significante para a melhoria do solo, visto que até uma tensão de $230 \mathrm{kPa}$, as curvas seguem coincidentes. Isso comprova que o reforço realizado apenas na projeção do elemento de fundação já é suficiente para aumentar sua capacidade de carga (não sendo necessário o reforço fora do elemento também por causa do espraiamento de tensões). As curvas referentes aos ensaios inundado e não inundado apresentam, também até esse nível de tensão de $150 \mathrm{kPa}$, praticamente os mesmos valores, comprovando a perda de instabilidade do solo devido ao colapso de sua estrutura por inundação.

Foram ainda comparados os resultados obtidos nos ensaios em centrífuga do presente estudo com o ensaio de prova de carga em um solo sem reforço realizado por Freitas (2016), conforme ilustrado na Figura 5.40 seguir.

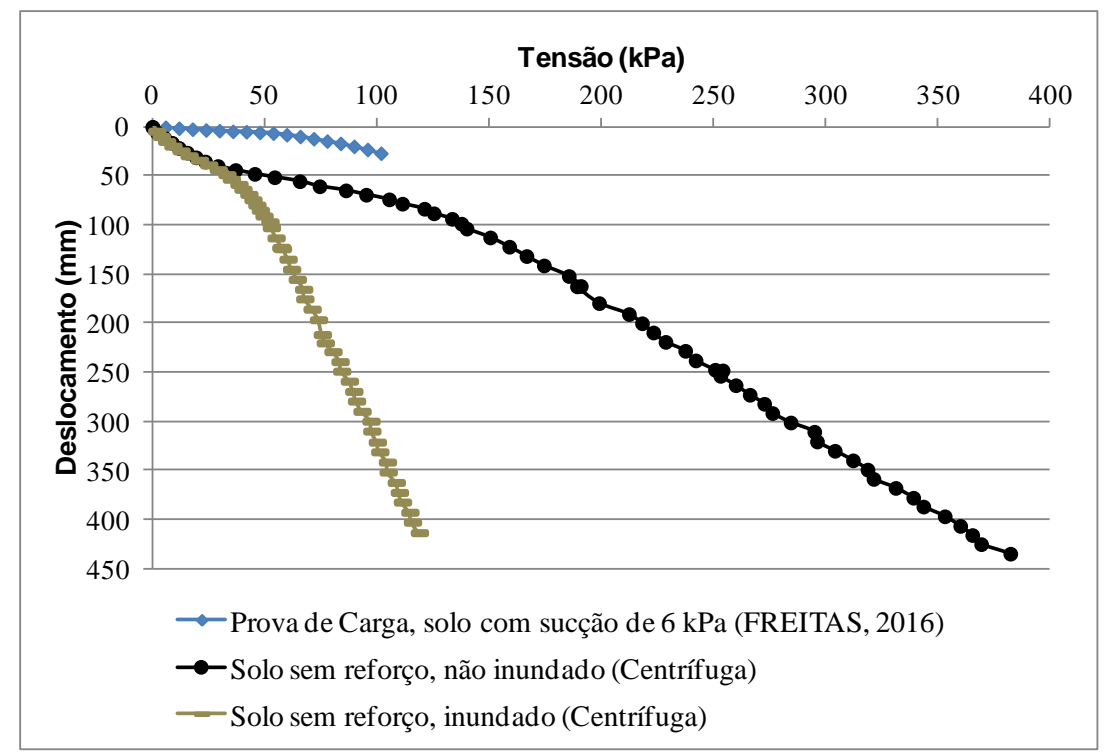

Figura 5.40: Comparação dos ensaios do solo sem reforço em centrífuga com o ensaio realizado por Freitas (2016) em prova de carga em campo.

A discrepância presenciada entre as curvas pode ser devida a diversos fatores, dentre eles a execução dos ensaios de carregamento em campo realizados em placa de dimensão reduzida $(80 \mathrm{~cm})$ comparada ao caso simulado em centrifuga $(200 \mathrm{~cm})$. Além disso, o processo 
de amostragem, secagem em estufa, peneiramento, destorroamento e umedecimento para procedimento de preparação causam grandes perturbações ao solo, como quebra de grãos e cimentação, e alteração de sua estrutura.

Além disso, o procedimento de compactação com o soquete em centrífuga também causa perturbações ao solo e não reproduz o estado e estrutura encontrados em campo, principalmente pelo fato do solo estudado ser laterítico e não saturado e apresentar sucção matricial (que causa um aumento temporário de resistência e que não é passível de reproduzir em modelo reduzido fidedignamente). Aliado à isso, tem-se ainda a não reprodução das trajetórias de secagem e umedecimento (histórico de sucção) que são presenciadas em campo ao longo de toda a vida do solo. O processo de reprodução do solo em laboratório não agrega tais trajetórias, que são fundamentais para o aumento da resistência do solo não saturado.

Tem-se ainda o fator relativo à tensão de cedência, referente à quebra da estrutura e a partir da qual as deformações não mais são recuperáveis. Devido à diferença da estrutura do campo para o ensaio, tal tensão de cedência acaba por não ser a mesma em ambas e causar também uma divergência entre os resultados obtidos.

Dessa forma, somando-se todos os fatores apresentados, torna-se muito complicada a reprodução de um solo laterítico, colapsível e não saturado em laboratório tal que seja presenciado seu estado exatamente como encontrado em campo (com cimentações, capilaridade, estrutura de vazios, distribuição dos macroporos e histórico de sucção entre outros).

\subsection{Modelagem Numérica}

Seguem abaixo os resultados obtidos para as modelagens da coluna experimental previamente realizada em campo e também dos resultados obtidos com a modelagem em centrífuga geotécnica. Para obtenção das curvas tensão versus deslocamento, utilizou-se o ponto mais próximo da origem do sistema cartesiano (ponto $0 ; 0$ ), que era coincidente com o centro da face inferior da placa de atuação, em seu contato com a superfície do solo. Foi testada uma convergência de malha, manualmente, sendo a mesma refinada até que fosse possível obter uma modelagem satisfatória (não demasiadamente demorada em termos de cálculo e que ao mesmo tempo pudesse conferir resultados reais e satisfatórios). 


\subsubsection{Modelagem de Coluna Experimental}

Foram realizados diversos modelos, variando tanto os parâmetros inseridos quanto a geometria adotada, tal que o modelo melhor convergisse ao resultado experimental (e sempre condizente com a realidade em campo). A seguir, é ilustrada uma primeira estimativa dos parâmetros, com as células hachuradas em cinza referentes aos parâmetros conhecidos e as em laranja, aos parâmetros arbitrados. O modelo constitutivo utilizado para todos os materiais geotécnicos foi o de Mohr-Coulomb.

Tabela 5.17: Primeira estimativa de parâmetros para as diferentes regiões de solos consideradas.

\begin{tabular}{|c|ccccc|}
\hline \multicolumn{1}{|c|}{$\boldsymbol{\gamma}\left(\mathbf{k N} / \mathbf{m}^{\mathbf{3}}\right)$} & $\boldsymbol{v}$ & $\boldsymbol{E}(\mathbf{k P a})$ & $\boldsymbol{c}(\mathbf{k P a})$ & $\boldsymbol{\phi}\left({ }^{\mathbf{}}\right)$ \\
\hline Coluna & 21,2 & 0,3 & 27330 & 30 & 38 \\
Solo à $\mathbf{2 5} \mathbf{~ c m}$ & 22,9 & 0,3 & 27330 & 30 & 38 \\
Solo à $45 \mathbf{~ c m}$ & 19,6 & 0,3 & 25000 & 15 & 34 \\
Campo & 16,2 & 0,3 & 8540 & 0 & 29 \\
\hline \multirow{5}{*}{ Legenda } & Parâmetros Conhecidos \\
& \multicolumn{5}{c}{ Parâmetros Arbitrados } \\
\hline
\end{tabular}

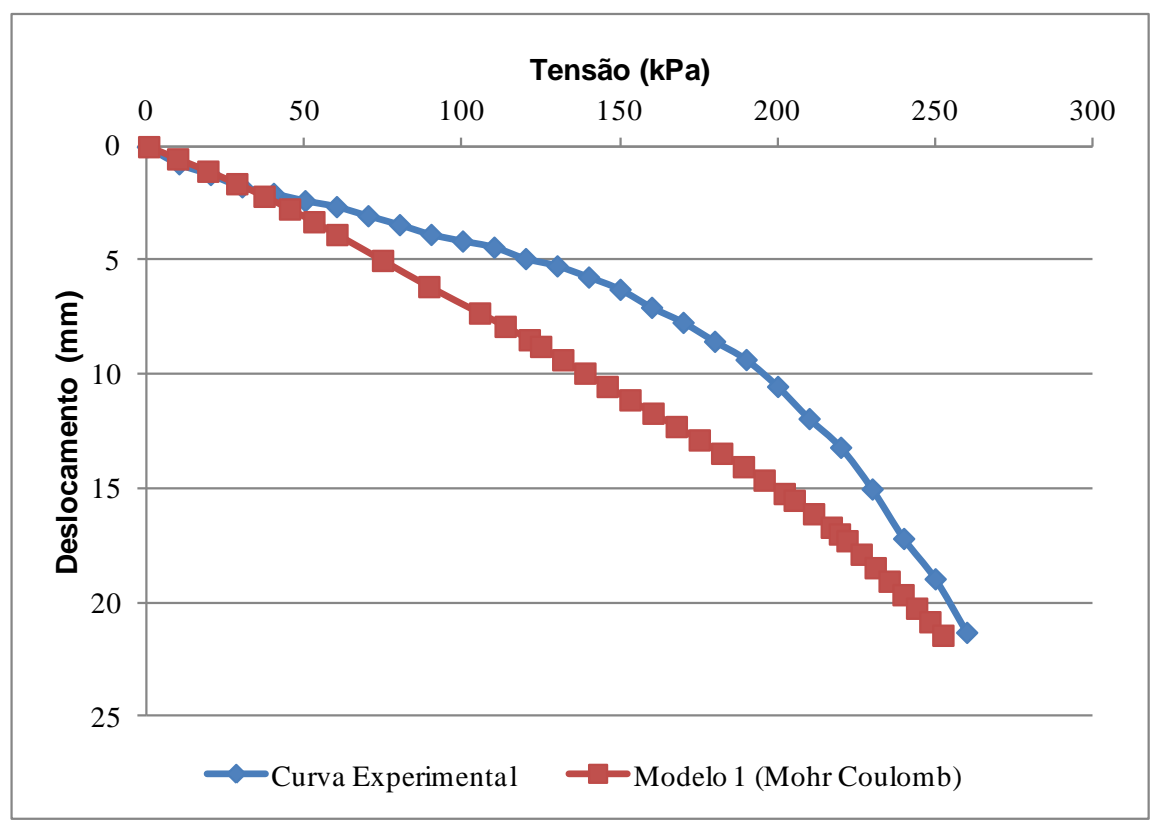

Figura 5.41: Curva tensão $x$ deslocamento do modelo calculado na Tentativa 1 inicial.

Com esses parâmetros, o modelo não ficou satisfatoriamente ajustado e foram então repetidos outros cálculos com diferentes parâmetros até que a curva numérica fosse mais satisfatoriamente ajustada à experimental. 
Notou-se que a alteração dos parâmetros de resistência e deformabilidade não eram tão influentes quanto a alteração da geometria do problema para o resultado final. Dessa forma, a geometria foi sendo ajustada (sempre condizente com o problema real) tal que os resultados convergissem para a curva experimental.

Outra consideração importante é a de que os parâmetros de resistência (coesão e ângulo de atrito) pouco influenciavam no resultado final. Quem mais governava o comportamento do solo e influenciava na curva era o módulo de deformabilidade. Com a alteração tanto dos parâmetros quanto da geometria, o resultado que melhor se aproximou da curva experimental segue ilustrado a seguir.

Tabela 5.18: Parâmetros com bom ajuste à curva experimental para a geometria apresentada.

\begin{tabular}{|cccccc|}
\hline & $\boldsymbol{\gamma}\left(\mathbf{k N} / \mathbf{m}^{3}\right)$ & $\boldsymbol{v}$ & $\boldsymbol{E}(\mathbf{k P a})$ & $\boldsymbol{c}(\mathbf{k P a})$ & $\boldsymbol{\phi}\left({ }^{\mathbf{0}}\right)$ \\
\hline Coluna & 21,2 & 0,35 & 30.200 & 20 & 33 \\
Solo à $\mathbf{2 5} \mathbf{~ c m}$ & 22,9 & 0,35 & 29.100 & 19 & 32 \\
Solo à $\mathbf{4 5} \mathbf{~ c m}$ & 19,6 & 0,35 & 27.800 & 15 & 30 \\
Campo & 16,2 & 0,35 & 9.100 & 5 & 28 \\
\hline
\end{tabular}

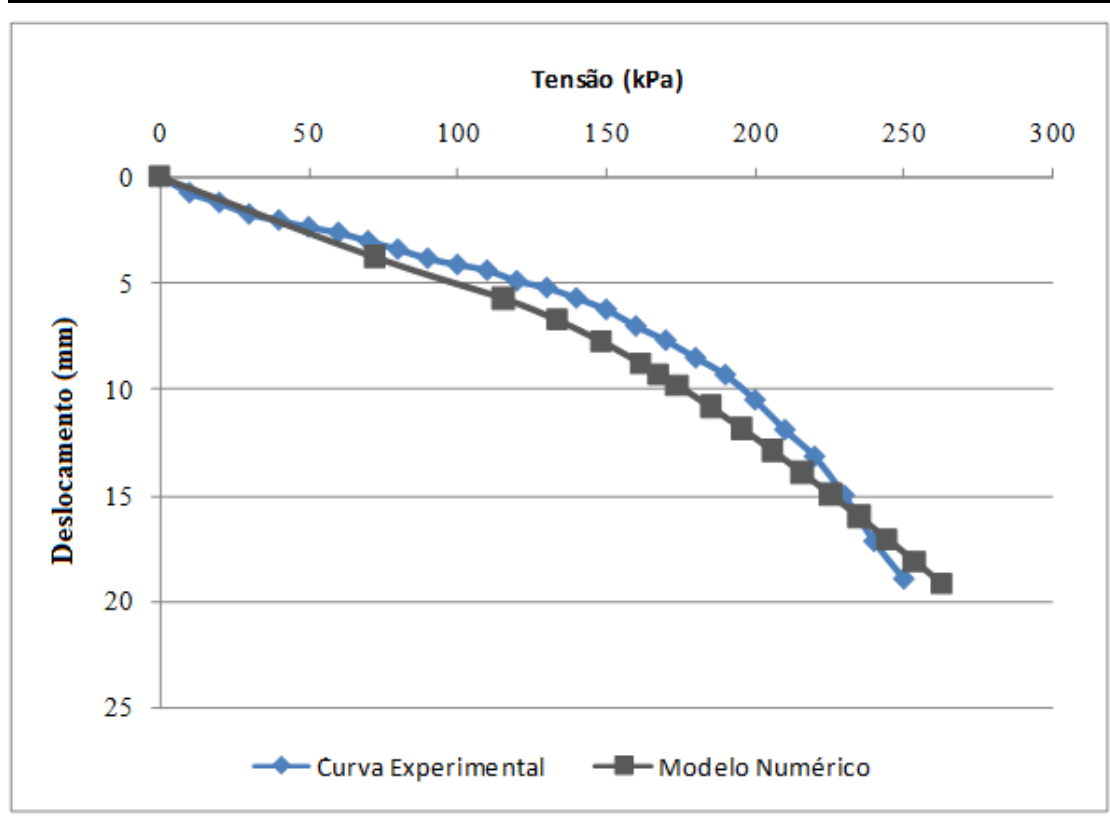

Figura 5.42: Curva tensão $x$ deslocamento com melhor ajuste à curva experimental.

Seguem ainda os resultados obtidos após o cálculo do modelo, que consistiu em apenas uma fase, na qual foram selecionados o elemento plate simulando a placa da prova de carga e o carregamento vertical uniforme de $300 \mathrm{kN} / \mathrm{m}^{2}$ ao longo de toda sua extensão. 

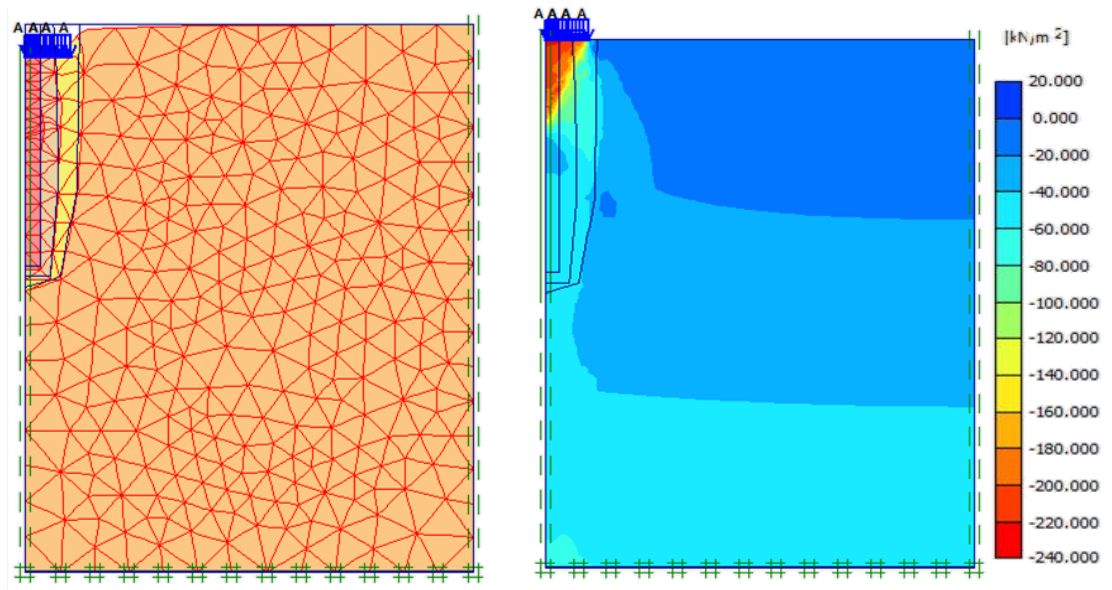

Figura 5.43: Malha deformada após o carregamento ter sido aplicado (à esquerda) e tensões efetivas obtidas após cálculo do modelo (à direita).
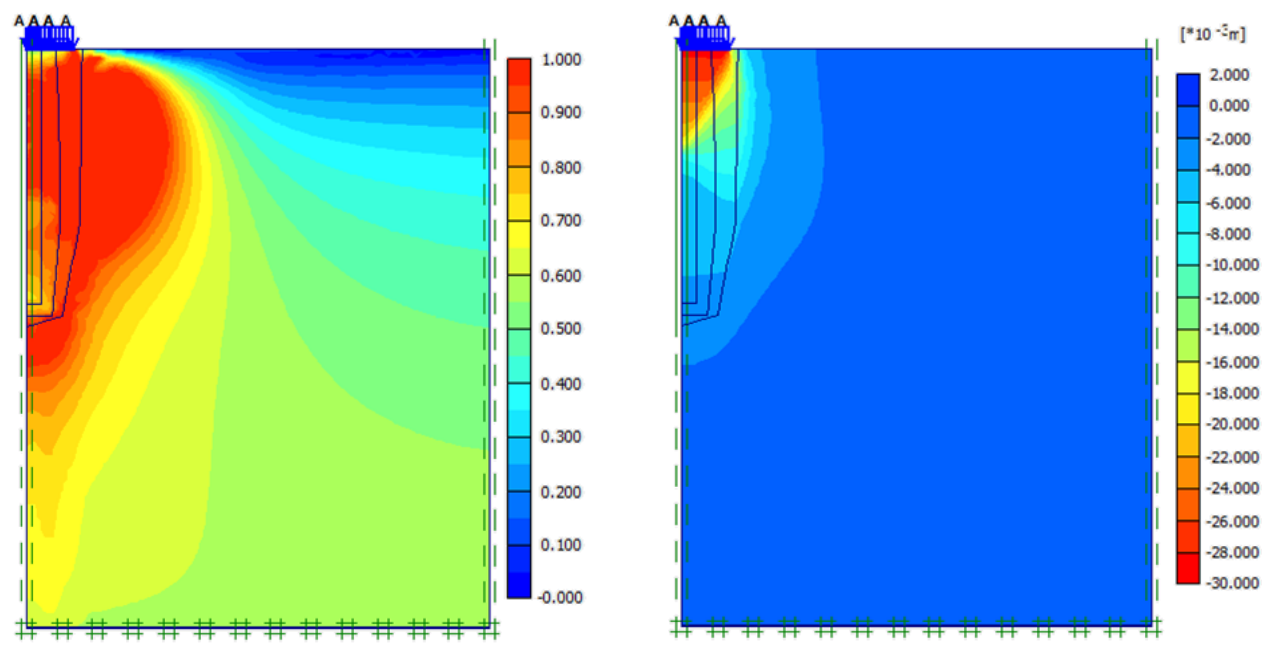

Figura 5.44: Tensões de cisalhamento relativas (à esquerda) e deslocamentos verticais (à direita) obtidos após cálculo do modelo.

\subsubsection{Modelagem dos Ensaios em Centrífuga Geotécnica}

Os resultados obtidos da modelagem numérica dos ensaios em centrífuga geotécnica realizados encontram-se expostos abaixo. 


\subsubsection{Solo sem Reforço}

Após diversas tentativas de parâmetros arbitrados, pelo modelo constitutivo de MohrCoulomb, o melhor resultado obtido, para o solo sem reforço, é ilustrado a seguir. Para verificação da influência da base compactada no modelo em questão, foi também feita uma modelagem numérica desconsiderando essa base (ou seja, considerando o solo sem reforço em toda a região do container). Os resultados obtidos foram similares tanto com a base compactada quanto sem sua presença, como ilustrado na Figura 5.45 abaixo.

Tabela 5.19: Parâmetros arbitrados para modelagem referente ao ensaio sem reforço em centrífuga geotécnica.

\begin{tabular}{|cccccc|}
\hline & $\gamma\left(\mathbf{k N} / \mathbf{m}^{3}\right)$ & $\boldsymbol{v}$ & $\boldsymbol{E}(\mathbf{k P a})$ & $\boldsymbol{c}(\mathbf{k P a})$ & $\boldsymbol{\phi}\left(^{\mathbf{o}}\right)$ \\
\hline Base Compactada & 20,0 & 0,3 & 18.000 & 5 & 35 \\
Solo Campo & 16,0 & 0,3 & 2.280 & 1,5 & 25,5 \\
\hline
\end{tabular}

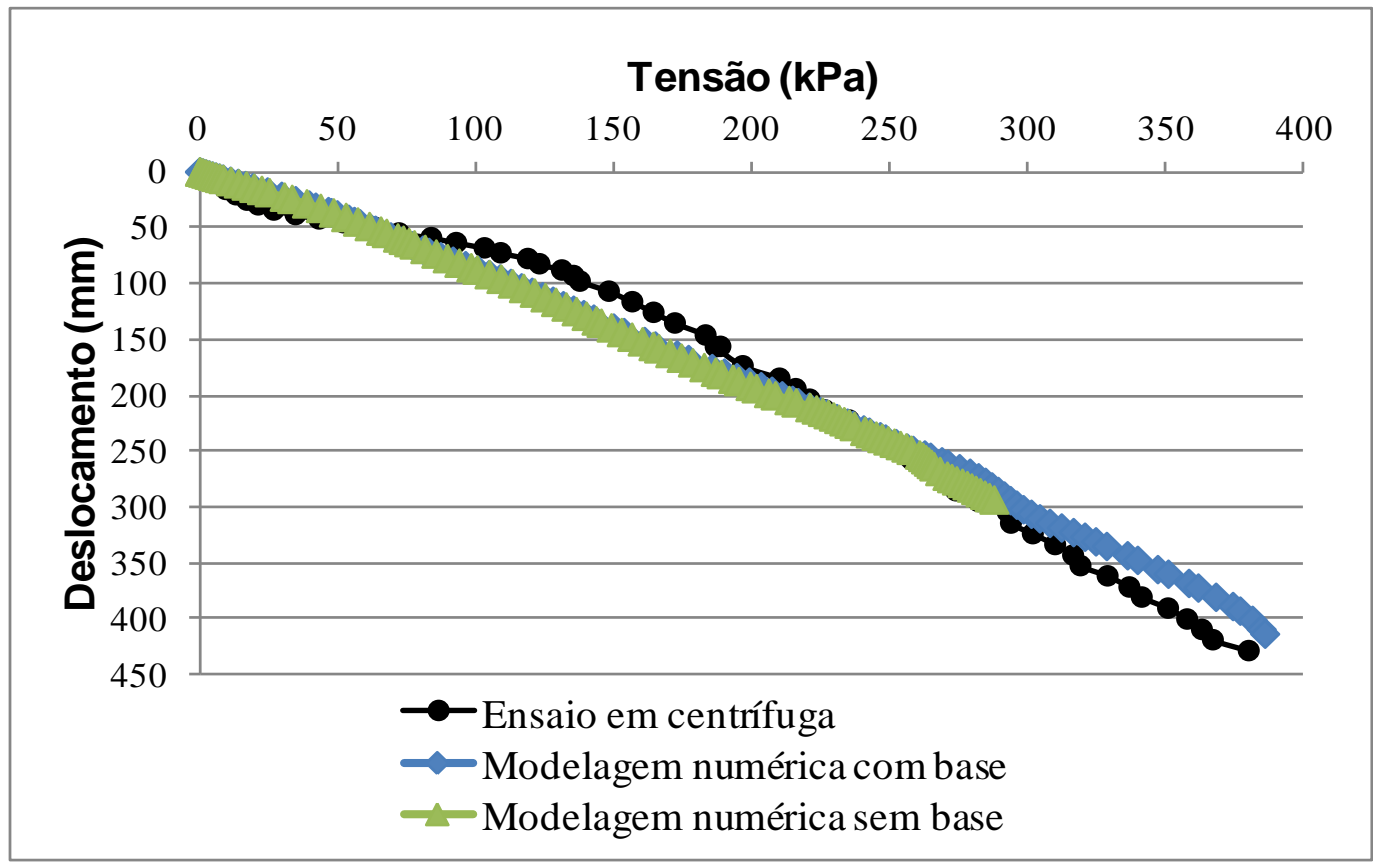

Figura 5.45: Curva tensão $x$ deslocamento das modelagens numéricas para o solo sem reforço em comparação com a ensaiada em centrífuga geotécnica.

Apesar de um bom resultado convergente (aproximação satisfatória das curvas experimental e numérica), é verificado um módulo de deformabilidade consideravelmente baixo para o solo natural em questão. Em campo, esse valor encontrado foi em torno de $9 \mathrm{MPa}$, ao passo que no software, o mesmo parâmetro foi arbitrado em torno de $2 \mathrm{MPa}$ tal que fosse possível o modelo convergir. Além disso, os parâmetros de resistência também foram inferiores na modelagem numérica do que aqueles encontrados em campo (o que já era esperado conforme mencionado ao final do item 5.3.3 do presente trabalho). Como tal modelagem foi referente 
apenas ao solo sem reforço (um único material geotécnico basicamente), não havia possibilidade de alterações na geometria, ficando a convergência do modelo dependente apenas dos parâmetros geotécnicos em questão.
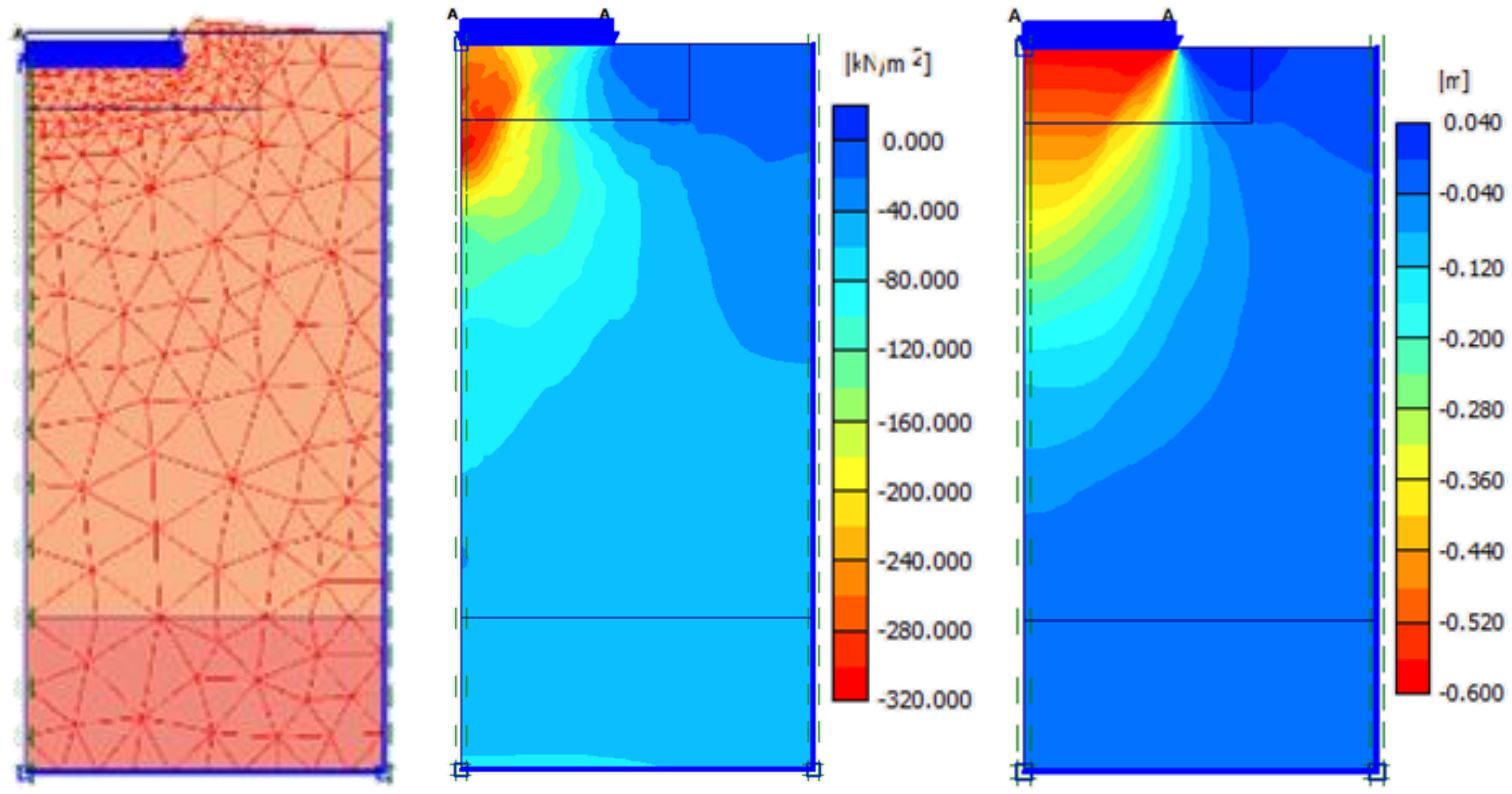

Figura 5.46: Malha deformada (à esquerda), tensões médias efetivas (ao centro) e deslocamentos verticais (à direita) para o solo sem reforço com a base compactada ao final do carregamento.
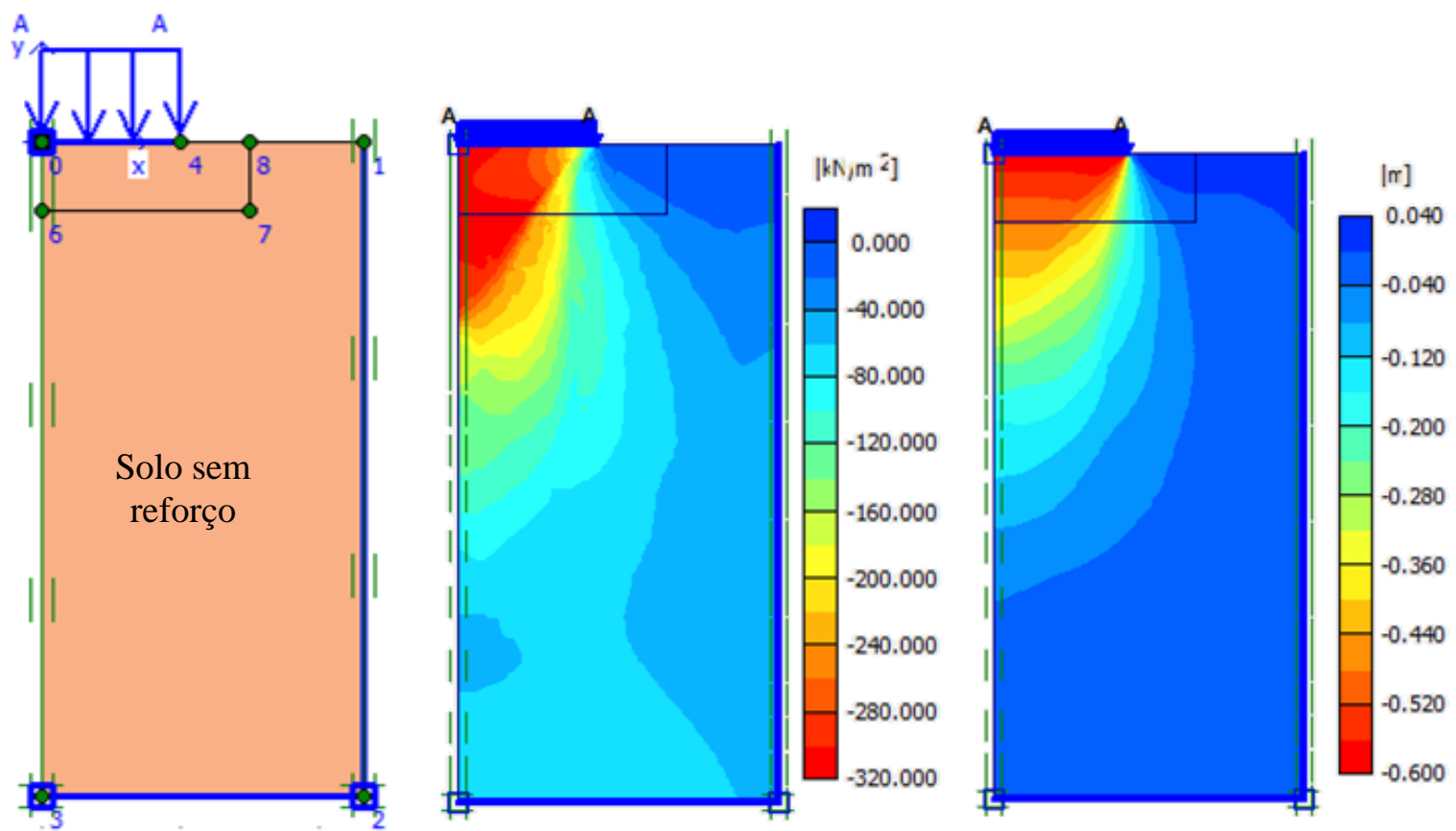

Figura 5.47: Geometria para o solo sem reforço e sem a base compactada (à esquerda), tensões médias efetivas (ao centro) e deslocamentos verticais (à direita) para o solo sem reforço sem base compactada ao final do carregamento. 
Após uma convergência satisfatória do modelo sem reforço na condição não inundada, elevou-se o nível d'água até a superfície do modelo para simular a condição saturada e obtenção da curva tensão $x$ deslocamento na condição inundada. No entanto, os resultados foram bem divergentes dos apresentados em modelagem física, uma vez que o software não consegue reproduzir a condição de solo não saturado e colapsível tal como o solo estudado encontra-se naturalmente. Dessa forma, foram modeladas numericamente apenas as condições não inundadas.

\subsubsection{Malha de colunas com espaçamento $4 d$}

Como os resultados entre os ensaios de 7 colunas e de 13 colunas foi muito similar (principalmente no trecho inicial de carregamento), julgou-se que os dispêndios para realização do reforço além do elemento de fundação era muito elevado face aos benefícios apresentados (quando comparado ao reforço apenas na projeção do elemento de fundação). Dessa forma, a modelagem numérica escolhida como representativa do espaçamento $4 d$ foi a referente ao ensaio de 7 colunas (apenas na região da placa), uma vez que julgou-se que o esforço para execução de reforço além do elemento não era compensado pelo ganho em resistência de modo geral. Como melhor ajuste encontrado, os parâmetros utilizados e a curva obtida encontram-se expostos a seguir.

Tabela 5.20: Parâmetros arbitrados para modelagem referente ao ensaio de espaçamento $4 d$ em centrífuga geotécnica.

\begin{tabular}{|cccccc|}
\hline & $\gamma\left(\mathbf{k N} / \mathbf{m}^{3}\right)$ & $\boldsymbol{v}$ & $\boldsymbol{E}(\mathbf{k P a})$ & $\boldsymbol{c}(\mathbf{k P a})$ & $\boldsymbol{\phi}\left(^{\mathbf{o}}\right)$ \\
\hline Base Compactada & 20,0 & 0,3 & 18.000 & 5 & 35 \\
Solo Campo & 16,0 & 0,3 & 2.280 & 3 & 27 \\
Solo Reforçado $4 \boldsymbol{d}$ & 21,4 & 0,3 & 40.000 & 30 & 34 \\
\hline
\end{tabular}




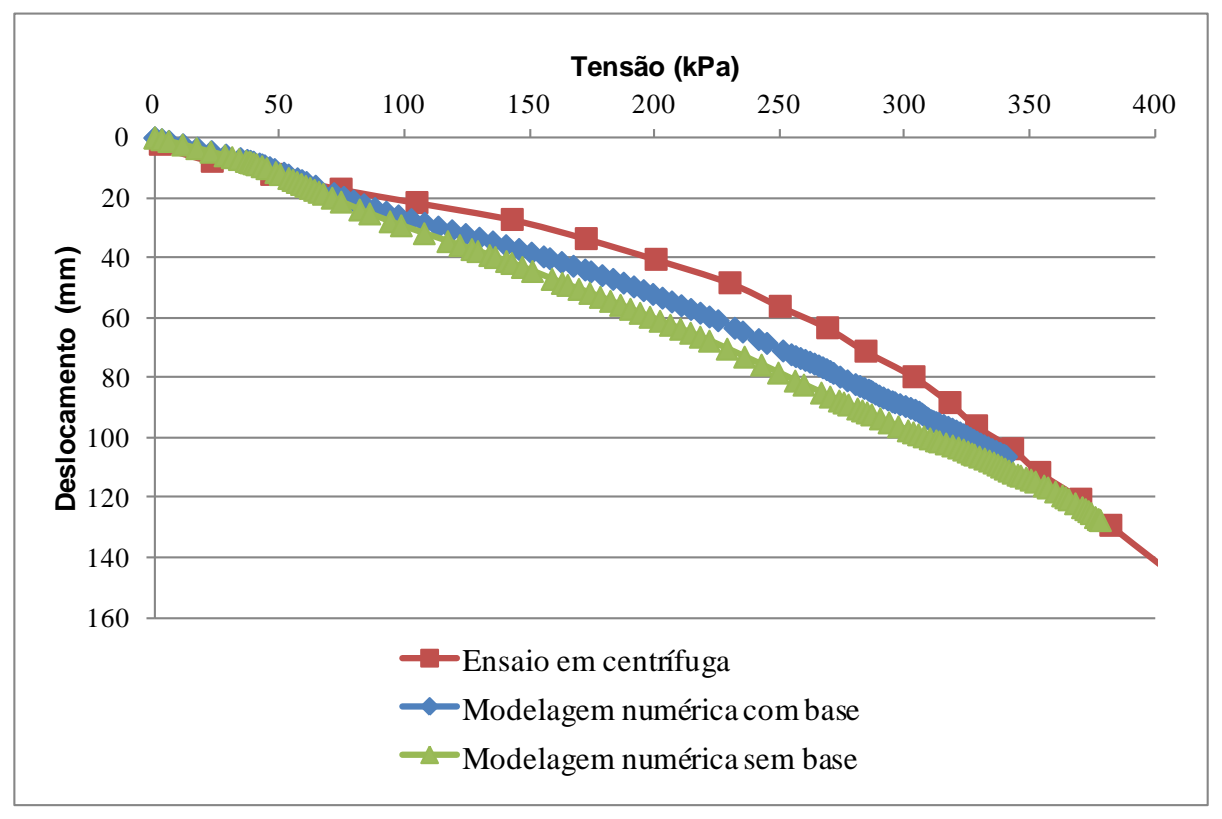

Figura 5.48: Curva tensão $x$ deslocamento da modelagem numérica para o solo reforçado com uma malha de espaçamento 4.d ensaiado em centrífuga geotécnica.
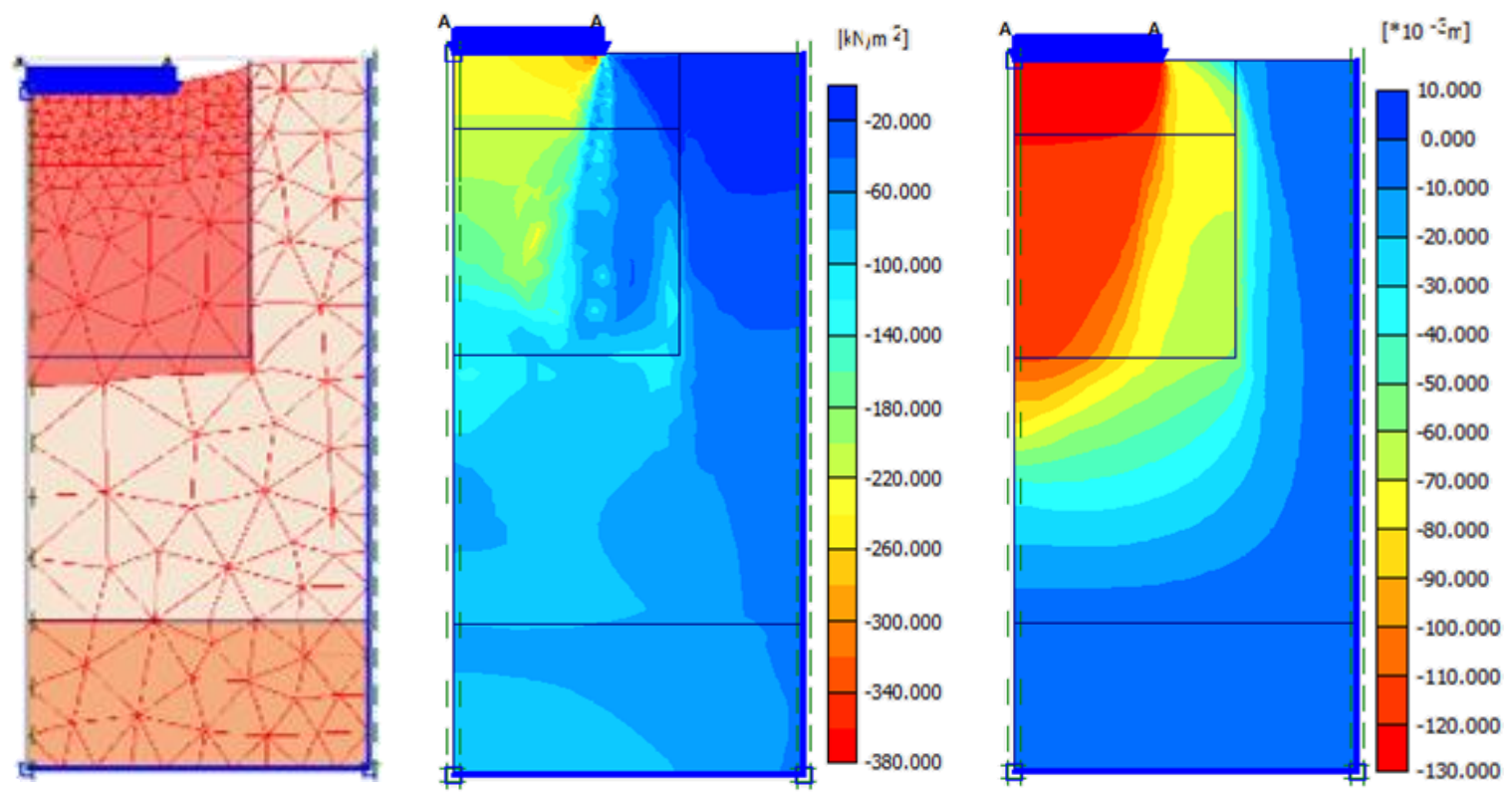

Figura 5.49: Malha deformada (à esquerda), tensões médias efetivas (ao centro) e deslocamentos verticais (à direita) para o solo reforçado com malha triangular de espaçamento 4.d (com base compactada) ao final do carregamento.

Considerando uma perturbação do solo sem reforço do container para cravação e execução das colunas, seus parâmetros de resistência foram minimamente alterados visando a reprodução dessa situação (que tende a compactar levemente o solo natural). Como ilustrado na Tabela 5.20, o solo sem reforço, que apresentava um módulo de deformabilidade equivalente de 
aproximadamente $2 \mathrm{MPa}$, foi melhorado significativamente graças a inclusão da malha de colunas de solo laterítico compactado, tendo seu módulo equivalente de deformabilidade elevado para $40 \mathrm{MPa}$. Ou seja, apenas pelo fato de reforçar o solo natural com uma malha triangular de colunas de solo laterítico compactado com espaçamento $4 d$, o módulo de deformabilidade equivalente foi elevado em cerca de 20 vezes, melhoria extremamente significativa para o solo em questão.

Referente aos parâmetros de resistência, o ângulo de atrito foi alterado de $25,5^{\circ}$ para $34^{\circ}$ e a coesão, que sofreu maiores alterações, foi aumentada de $1,5 \mathrm{kPa}$ para $30 \mathrm{kPa}$ (um aumento também de 20 vezes).
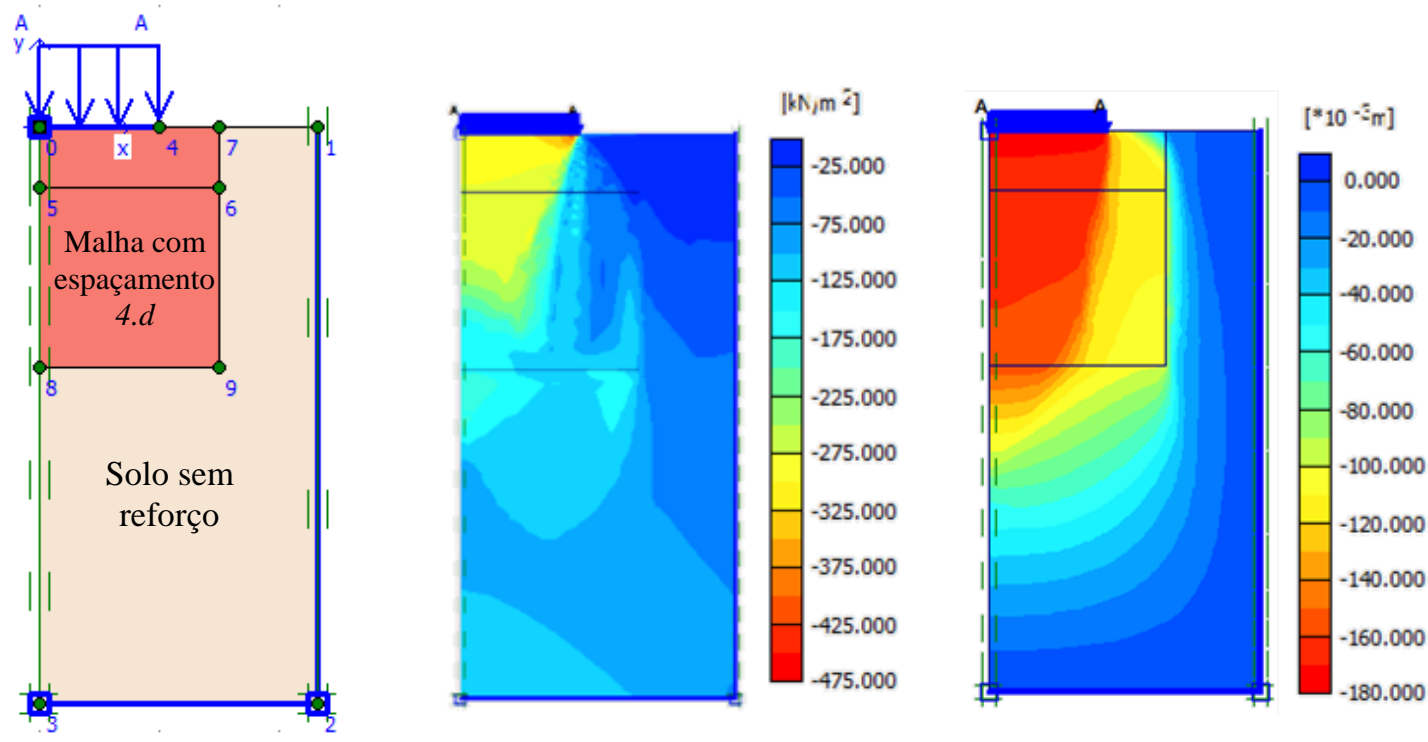

Figura 5.50: Geometria e materiais considerados no modelo numérico (à esquerda); tensões médias efetivas (imagem central) e valores de deslocamentos verticais (à direita) obtidos para a malha com espaçamento 4.d sem a base compactada ao final do carregamento.

A região equivalente do reforço pela malha de colunas é relativamente rígida, fazendo com que ocorra um comportamento em que as propagações das tensões são transferidas pelas colunas para regiões mais profundas. Alguns autores defendem que, quando os reforços são pouco espaçados (havendo um comportamento como um elemento único), o bulbo de tensões de 2.B pode ser considerado não mais a partir da base do elemento de fundação direta (placa apoiada na superfície) mas sim a partir do fim das colunas (elemento único).

Partindo dessa premissa, as tensões seriam, portanto, propagadas até o final do container de teste, as quais previamente eram resistidas em parcela pela base compactada. Ao retirar-se essa base e deixar o solo menos resistente, as deformações atingiram níveis um pouco mais elevados. 
Dessa forma, é importante analisar, quando o elemento de reforço for muito rígido e conferir uma resistência muito discrepante do solo em questão, o bulbo de tensões poderá chegar a regiões mais profundas do que quando comparado ao solo não reforçado (para um mesmo elemento de fundação solicitante).

\subsubsection{Malha de colunas com espaçamento $5 d$}

Por fim, para o reforço com a malha quadrada de espaçamento $5 d$, os melhores resultados obtidos são ilustrados a seguir.

Tabela 5.21: Parâmetros arbitrados para modelagem referente ao ensaio de espaçamento $4 d$ em centrífuga geotécnica.

\begin{tabular}{|cccccc|}
\hline & $\boldsymbol{\gamma}\left(\mathbf{k N} / \mathbf{m}^{\mathbf{3}}\right)$ & $\boldsymbol{v}$ & $\boldsymbol{E}(\mathbf{k P a})$ & $\boldsymbol{c}(\mathbf{k P a})$ & $\boldsymbol{\phi}\left({ }^{\mathbf{o}}\right)$ \\
\hline Base Compactada & 20,0 & 0,3 & 18.000 & 5 & 35 \\
Solo Campo & 16,0 & 0,3 & 2.280 & 3 & 27 \\
Solo Reforçado $5 \boldsymbol{d}$ & 19,0 & 0,3 & 2.700 & 4 & 30 \\
\hline
\end{tabular}

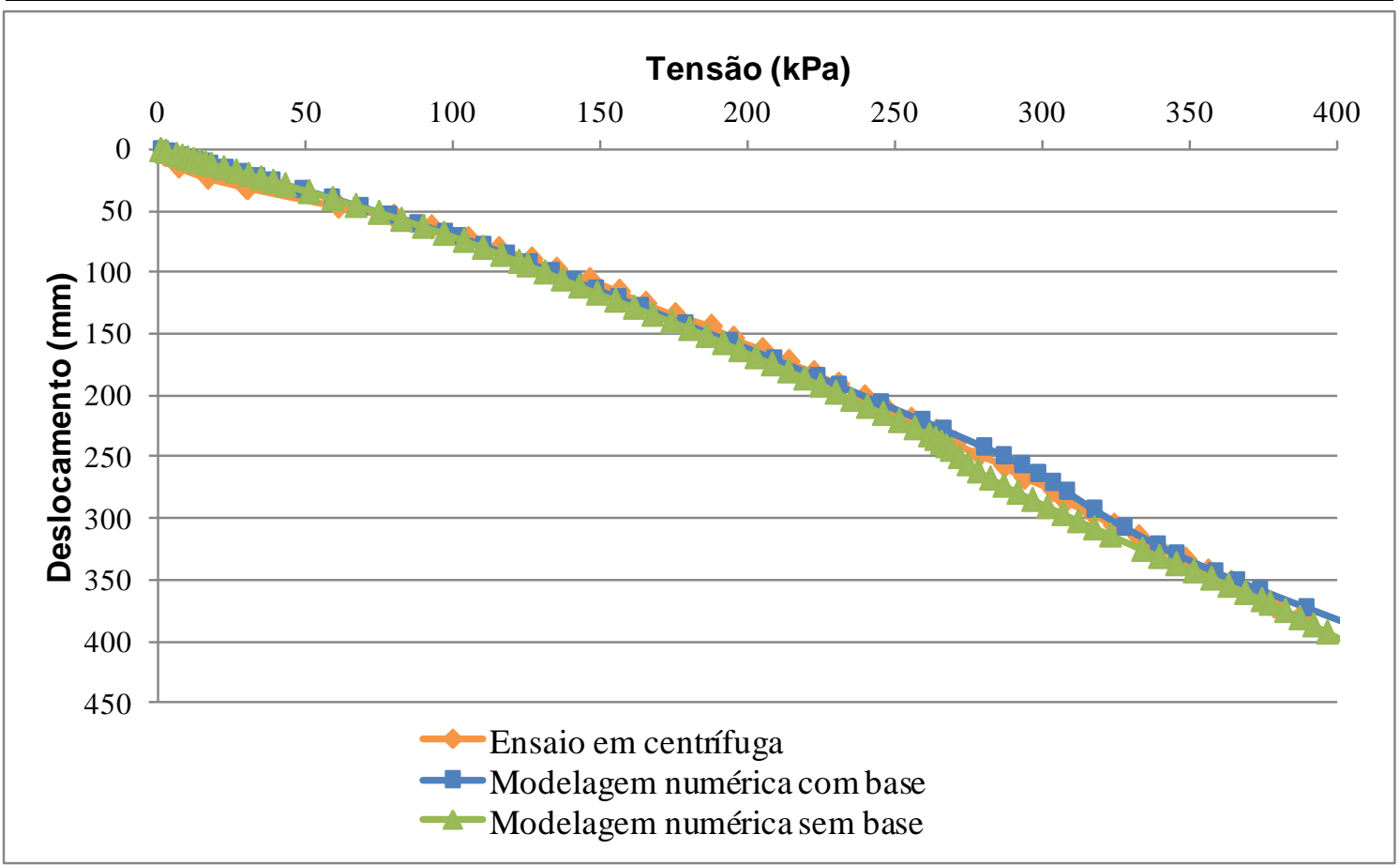

Figura 5.51: Curva tensão $x$ deslocamento da modelagem numérica para o solo reforçado com uma malha de espaçamento $5 d$ ensaiado em centrífuga geotécnica.

Já para o solo reforçado com uma malha quadrada de colunas com espaçamento $5 d$, a melhoria do solo em questão não foi tão significativa, principalmente quando comparada com a 
malha triangular de espaçamento $4 d$. O volume de solo reforçado, perturbado pelo processo executivo das colunas, nesse caso foi menor quando comparado com o volume da malha triangular de espaçamento $4 d$. Além disso, a quantidade de colunas era menor (quase metade do melhor resultado apresentado, com 7 colunas) e também a geometria da disposição da malha não era favorável para com a geometria ensaiada em centrífuga. Tanto a placa de atuação quanto o container de ensaio eram de seções transversais circulares, enquanto a malha apresentava uma disposição quadrada, não otimizando assim o processo de reforço.

Por essas e outras razões (como talvez a de o espaçamento $5 d$ ser excessivo) é que o solo sofreu pouca melhoria quando comparado ao seu estado natural, tendo seu módulo de deformabilidade aumentado apenas em meia vez (50\%), passando de 2,3 MPa para 2,7 MPa. Os parâmetros de resistência, traduzidos no modelo pela coesão e ângulo de atrito, foram pouco alterados de 3 para $4 \mathrm{kPa}$ e 27 para 30 graus respectivamente.
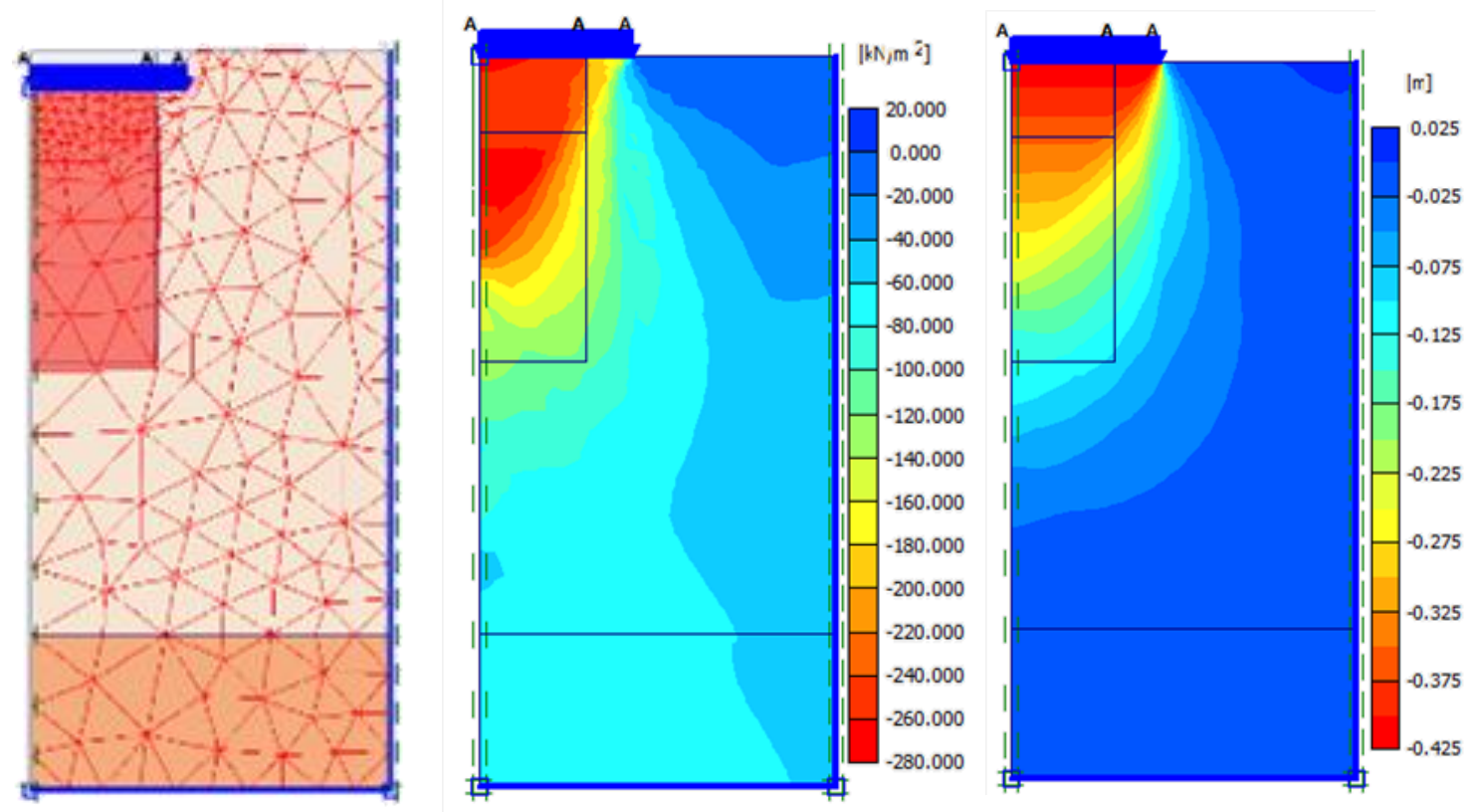

Figura 5.52: : Malha deformada (à esquerda), tensões médias efetivas (ao centro) e deslocamentos verticais (à direita)para o solo reforçado com malha triangular de espaçamento $5 d$ ao final do carregamento.

Para a modelagem numérica desconsiderando a base compactada, os resultados obtidos foram praticamente idênticos, conforme ilustrado a seguir. 

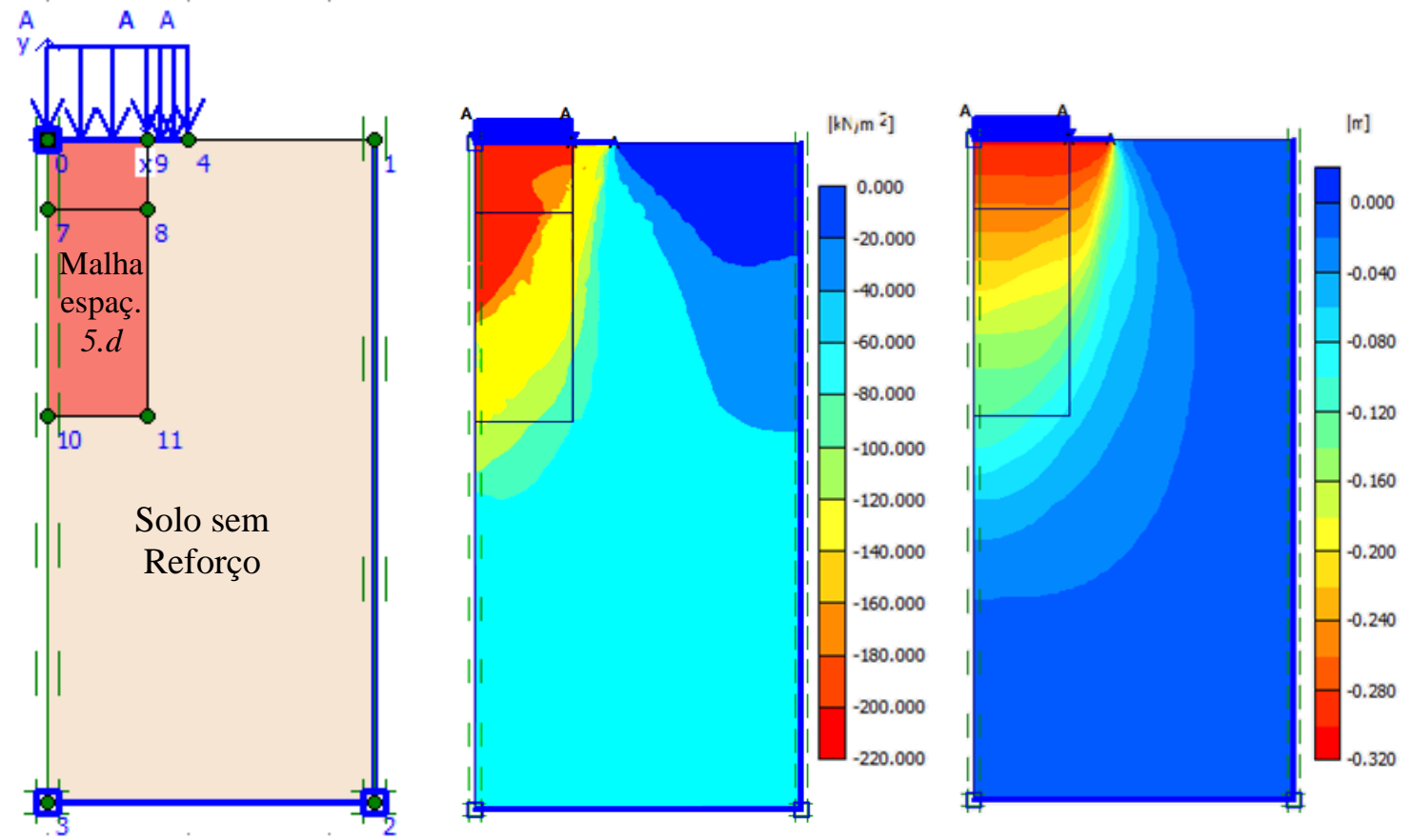

Figura 5.53: Geometria e materiais considerados no modelo numérico (à esquerda); tensões médias efetivas (imagem central) e valores de deslocamentos verticais (à direita) obtidos para a malha com espaçamento $5 d$ sem a base compactada ao final do carregamento.

Finalmente, para melhor ilustrar os resultados obtidos com as modelagens numéricas realizadas, são apresentados na Tabela 5.22 a seguir todos os parâmetros utilizados nas mesmas, a título de comparação entre o solo sem reforço as diferentes malhas estudadas.

Tabela 5.22: Síntese dos parâmetros utilizados para as modelagens numéricas realizadas.

\begin{tabular}{|c|c|c|c|c|c|}
\cline { 2 - 6 } \multicolumn{1}{c|}{} & $\gamma\left(\mathbf{k N / \mathbf { m } ^ { 3 } )}\right.$ & $\boldsymbol{v}$ & $\boldsymbol{E}(\boldsymbol{k P a})$ & $\boldsymbol{c}(\boldsymbol{k P a})$ & $\boldsymbol{\phi}\left({ }^{\mathbf{o}}\right)$ \\
\hline Base Compactada & 20,0 & 0,3 & 18.000 & 5,0 & 35,0 \\
\hline Solo sem Reforço & 16,0 & 0,3 & 2.280 & 1,5 & 25,5 \\
\hline $\begin{array}{c}\text { Solo natural (como região para os } \\
\text { ensaios reforçados) }\end{array}$ & 16,0 & 0,3 & 2.280 & 3,0 & 27,0 \\
\hline $\begin{array}{c}\text { Malha triangular com espaçamento 4d } \\
\text { Malha quadrada com espaçamento } 5 d\end{array}$ & 21,4 & 0,3 & 40.000 & 30,0 & 34,0 \\
\hline
\end{tabular}


É possível verificar que os colapsos decrescem com o aumento do grau de compactação. Para graus de compactação mais elevados (principalmente acima de 90\%), os efeitos de colapso da estrutura por inundação do solo são consideravelmente atenuados. Por esse motivo que vem sendo estudada a técnica de reforço de solo colapsível através de colunas de solo laterítico compactado.

Para o solo estudado, com índices de vazios na ordem da unidade, são presenciados potenciais de colapso superiores a 14\% (para uma tensão de $100 \mathrm{kPa}$ ). Quando compactados nos parâmetros ótimos, o potencial de colapso, para a mesma tensão, é reduzido à zero (ou seja, são anulados os efeitos de colapso quando o solo encontra-se bem compactado).

Uma coluna isolada mostrou bons resultados quanto ao reforço do solo colapsível, mas não havia ainda a noção do comportamento de uma malha de colunas tal que fosse possível reforçar a camada para adoção de fundações diretas. Uma vez que a execução de diferentes malhas de colunas de solo laterítico compactado era inviável em termos técnicos e econômicos, recorreu-se às modelagens física e numérica.

Dos resultados em centrífuga, a malha triangular com espaçamento $4 d$ mostrou-se a mais eficaz para reforço do maciço. Nessas condições, não foram verificadas grandes diferenças comparando o ensaio com colunas apenas na região de projeção da placa ( 7 colunas) com o ensaio com colunas tanto da região da placa como também em sua adjacência (13 colunas). A quantidade de colunas praticamente dobrou (de 7 para 13 colunas) sendo que a redução dos deslocamentos não foi tão significante (principalmente para tensões mais baixas), não justificando a necessidade de execução de colunas além do elemento de fundação.

A malha quadrada com espaçamento $5 d$ apresentou um resultado irrisório, não reforçando em nada o maciço para tensões mais baixas. Esse fato pode ser atribuído a diversos fatores, em proporções diferentes e não conhecidas. Pode ser pela quantidade de colunas ser pequena (apenas 4), pelo espaçamento ser alto ou ainda pela geometria da malha ser quadrada enquanto a do container e do elemento de fundação eram circulares.

A viabilidade dessa técnica de reforço reside na possibilidade da adoção de fundações diretas em solo colapsível, os quais geralmente são solicitados por tensões mais baixas (na 
ordem de $100 \mathrm{kPa}$ ). Para essa faixa de tensão, o solo reforçado, mesmo quando inundado, apresenta recalques extremamente inferiores ao solo sem reforço inundado. $\mathrm{O}$ solo sem reforço inundado (pior situação possível), para uma tensão de $100 \mathrm{kPa}$, apresentou um recalque de 38 $\mathrm{mm}$, ao passo que para a mesma tensão, o solo reforçado inundado apresentou recalques de $4 \mathrm{~mm}$ (cerca de $10 \%$ apenas).

Diversos aspectos influenciam na convergência de uma boa modelagem. Primeiramente, a geometria escolhida deve ser condizente com a real para que os resultados possam ser satisfatórios. Como o processo de execução da coluna em campo não permite uma viabilidade executiva para escarificação e noção de sua geometria, foram executados estudos em modelo reduzido que possibilitaram uma noção acerca da modificação da geometria do furo após a compactação.

Vale salientar que essa geometria serve apenas de embasamento, pois não é possível garantir que o resultado do modelo físico reduzido é exatamente o ocorrido em campo, visto que as energias e processos de compactação diferem do modelo para o campo.

Outro importante aspecto que culmina para uma boa convergência do modelo numérico são os parâmetros fornecidos, bem como o modelo constitutivo escolhido. O modelo deve levar em consideração não somente o tipo do solo (refletido, portanto, em seu comportamento), mas também nos parâmetros possíveis de serem estimados ou conhecidos. Para a modelagem em questão, o modelo escolhido como o mais satisfatório refere-se ao de Mohr-Coulomb, uma vez que eram de certa forma conhecidos os módulos de deformabilidade e os demais parâmetros, como coeficiente de Poisson e parâmetros de resistência, eram facilmente arbitrados com base na literatura para o solo arenoso envolvido.

Os resultados obtidos na modelagem numérica realizada nesse estudo foram satisfatórios, uma vez que as curvas numéricas assemelharam-se consideravelmente às experimentais. Para a modelagem da coluna isolada executada experimentalmente, o modelo axissimétrico em duas dimensões traduziu bem o encontrado em campo. Já para as diferentes malhas de colunas executadas em centrífuga geotécnica, uma modelagem em três dimensões seria mais interessante para noção acerca dos parâmetros e comportamentos das colunas em questão. Na modelagem dessa etapa, realizada aqui em duas dimensões, foram adotados parâmetros médios representativos de uma região reforçada pela execução das colunas (arbitrada conforme exumação do container após ser ensaiado). 
Para o solo sem reforço, o módulo de deformabilidade equivalente arbitrado satisfatoriamente foi de 2,3 MPa, sendo aumentado apenas para 2,7 MPa para a malha quadrada de espaçamento $5 d$ e para $40 \mathrm{MPa}$ para a malha triangular de espaçamento $4 d$ (cerca de 20 vezes, valor altamente significativo). Quanto aos parâmetros de resistência, representados no modelo constitutivo de Mohr-Coulomb por coesão e ângulo de atrito, houve uma aumento de 20 vezes na coesão do solo sem reforço para o reforçado com a malha de $4 d$ enquanto o ângulo de atrito aumentou de $25,5^{\circ}$ para $34^{\circ}$. Já para a malha de $5 d$, houve um aumento na coesão de 1,5 para $4 \mathrm{kPa}$ e no ângulo de atrito de $25,5^{\circ}$ para $30^{\circ}$.

Um aspecto demasiadamente relevante referente ao método de reforço de um solo colapsível através de uma malha de colunas de solo laterítico compactado reside em sua viabilidade técnica, econômica e ambiental. O processo executivo é simplificado, não necessitando a mobilização de equipamentos mais complexos e onerosos para execução de estacas elaboradas ou de grandes aterros compactados. E, por fim, é utilizado o próprio material geotécnico (que seria rejeito da escavação) como material de reforço, contribuindo como uma solução sustentável, fácil e rapidamente exequível, não onerosa e, principalmente, eficaz para reforço da camada colapsível. 


\section{SUGESTÕES PARA TRABALHOS FUTUROS}

- Realização de uma modelagem numérica em três dimensões para noção do comportamento da malha e comparação com os parâmetros equivalentes da modelagem em duas dimensões realizada no presente trabalho.

- Realização de ensaios triaxiais e de cisalhamento direto para conferência dos parâmetros de resistência (coesão e ângulo de atrito) do solo estudado, a diferentes graus de compactação, para facilitar a inclusão de parâmetros nos softwares de modelagem numérica.

- Execução de novos ensaios em centrífuga geotécnica, agora com um mapeamento da superfície inferior da placa de atuação, através de sensores a partir dos quais seja possível a distinção da parcela resistida por cada coluna e também pelo solo.

- Execução de ensaios de carregamento em campo de sapatas apoiadas em solo colapsível reforçado por grupos de colunas de solo laterítico compactado. Nestes ensaios deve-se realizar a inundação do solo durante o carregamento para avaliar a possibilidade de recalques de colapso. 
1. ALVES, L. M. (2007) Método dos Elementos Finitos. Apostila da Universidade Federal do Paraná. 438 f.

2. BUENO, B. S.; VILAR, O. M. (1979) Apostila de Mecânica dos Solos, v. 1, São Carlos/Viçosa.

3. CAMPOS, T. M. P. (1997) Resistência ao cisalhamento de solos não saturados. Anais do $3^{\circ}$ Simpósio Brasileiro de Solos Não Saturados. ÑSAT’97, Rio de Janeiro, v. 2, p. 399-408.

4. CASTRO, A. P. A.; SOARES, F. V. P.; RODRIGUES, R. A. (2017) Compactação como método de melhoria de solo colapsível. Fundações e Obras Geotécnicas, ano 7, n. 76, janeiro de 2017. p. 42-51.

5. CINTRA, J. C. A. (1998) Fundações em Solos Colapsíveis. São Carlos, Serviço Gráfico da EESC/USP. 116p.

6. CINTRA, J. C. A.; AOKI, N. (2009) Projeto de Fundações em Solos Colapsíveis. São Carlos, Serviço Gráfico da EESC/USP. 108p.

7. CINTRA, J. C. A.; LEVACHER, D; GARNIER, J. (1990) Carregamento Lateral em Modelos de Grupos de Estacas em Centrífugas. Anais do $6^{\circ}$ CBGE - IX COBRAMSEF, vol. 2, p. $333-339$.

8. DELGADO, A. K. C. (2002) Influência da sucção no comportamento de um perfil de solo tropical compactado. 211 p. Dissertação (Mestrado) - Faculdade de Tecnologia, Universidade de Brasília.

9. FABBRI, G. T. P. (1994) Caracterização da fração fina dos solos tropicais através da adsorção de azul de metileno. 176 p. Tese (Doutorado) - Escola de Engenharia de São Carlos, Universidade de São Paulo. 
10. FERREIRA, R. C. \& MONTEIRO, L. B. (1985) Identification and evaluation of collapsibility of colluvial soils that occur in the São Paulo State. International conference on geomechanics in tropical lateritic and saprolitic soils. Brasília, ABMS, ISSMFE.

11. FREITAS, M. C. (2016) Avaliação de técnica de melhoria de solos colapsíveis por meio de colunas de solo laterítico compactado. 200 p. Dissertação (Mestrado) Escola de Engenharia de São Carlos, Universidade de São Paulo.

12. FUGLSANG, L. D. \& OVESEN, N. K. (1988) The application of the theory of modelling to centrifuge studies. Centrifuge in Soil Mechanics, p. 119-138, Ed. Balkema, Rotterdam.

13. GARDNER, R. (1937) A method of measuring the capillary tension of soil moisture over a wide moisture range. Soil Science, vol. 43, p 277-283.

14. GIACHETI, H. L.; PEIXOTO A. S. P.; MONDELLI, G. (2004) Comparação entre resultados de ensaios de penetração com os cones mecânico e elétrico em solos tropicais. Solos e Rochas, São Paulo, 27, p. 191-200

15. GUSMÃO, A. D. (2005) Melhoramento de terrenos arenosos. Capítulo 6. Pernambuco: Universidade Federal de Pernambuco, v. 1, p. 331-363.

16. GUTIERREZ, N. H. M. (2005) Influência de aspectos estruturais no colapso de solos do norte do Paraná. 311 p. Tese (Doutorado) - Escola de Engenharia de São Carlos, Universidade de São Paulo.

17. HOGENTOGLER, C. A. (1937) Engineering properties of soil. New York: McGraw Hill.

18. KISHIDA, H.; MEYERHOF, G. G. (1965) Bearing capacity of pile groups under eccentric loads in sand. International Conference on Soil Mechanics and Foundation Engineering, Toronto, v. 2, p. 270-274. 
19. LIVINGSTON, B. E. (1906) The relation of desert plants to soil moisture and to evaporation. Cargenic Inst. Plub. n. 50.

20. LODI, P. C. (1998) Aplicação do modelo Cam-Clay modificado a um solo arenoso. 144p. Dissertação (Mestrado) - Escola de Engenharia de São Carlos, Universidade de São Paulo.

21. LOPES, A. B. S. P (2015) Estudo de ensaios em centrífuga geotécnica. (Projeto de Graduação). Universidade de Brasília (DF). 55p.

22. MACHADO, L. M.(2016) Modelagem física em centrífuga geotécnica de reforço de solos moles com colunas granulares. (Projeto de Graduação). Escola Politécnica, Universidade Federal do Rio de Janeiro. 108p.

23. MARINHO, F. A. M. (1997) Medição de Sucção em Solos. Anais do $3^{\circ}$ Simpósio Brasileiro de Solos Não Saturados. ÑSAT’97, Rio de Janeiro, v. 2, p. 373-397.

24. MASCARENHA, M.; NETO, M. P. C.; NETO, P. M. S. MORALES, E. R. (2008) Utilização da porosimetria por injeção de mercúrio (MIP) na determinação de curvas características em solos deformáveis.

25. MÉLO, V. S. (2011) Classificação e estabilização de solos lateríticos do estado da Paraíba e do Rio Grande do Norte. 109 p. Dissertação (Mestrado). Centro de Tecnologia e recursos naturais, Universidade Federal de Campina Grande.

26. Menegotto, M. L. (2004) Precisão da curva tensão-recalque de ensaios de placa em solo não saturado. 224 p. Tese (Doutorado) - Escola de Engenharia de São Carlos, Universidade de São Paulo.

27. MEYERHOF, G. G. Bearing capacity and settlement of pile foundations. The eleventh Terzaghi lecture, journal of Geothecnical Engineering Division, v. 102, n. GT3, p. 195-228.

28. MOTTA, E. Q. (2006) Análise do colapso de um solo compactado devido à inundação e à interação solo-líquido contaminante. 131 p. Dissertação (Mestrado) - Universidade Federal de Pernambuco. Recife, Pernambuco. 
29. NOGAMI, J. S.; VILLIBOR, D. F. (1981) Uma nova classificação de solos para finalidades rodoviárias. Simpósio Brasileiro de Solos Tropicais em Engenharia, Rio de Janeiro, v. 1, p. 30-41.

30. PEREIRA, M. S. (2013) Influência da Compactação na Curva de Retenção de água e na condutividade hidráulica de um solo arenoso. Relatório de Iniciação Científica, Universidade Estadual Paulista, Campus de Bauru. Faculdade de Engenharia de Bauru. 61p.

31. PINTO, C. S. (2009) Curso Básico de Mecânica dos Solos. $3^{\text {a }}$ Edição. Oficina de Textos.

32. PORTAL DE TECNOLOGIA (2010) Considerações sobre solos tropicais e Conceito de Pavimentos de Baixo Custo. Retirado de http://www.portaldetecnologia.com.br/tags/saproliticos/, acesso em 07/02/2017 às $11 \mathrm{~h} 20$.

33. QUINALIA, E. (2009) Estabilização de solos moles por vibrocompactação. Retirado de http://techne.pini.com.br/engenharia-civil/145/artigo285456-1.aspx, acesso em 18 de julho de 2016.

34. RODRIGUES, R. A. (2009) Modelação das deformações por colapso devidas à ascensão do lençol freático. $298 \mathrm{f}$. Tese (Doutorado) - Escola de Engenharia de São Carlos, Universidade de São Paulo, São Carlos.

35. RODRIGUES, R. A. \& CARVALHO, J. C. (2015) Solos não saturados no contexto geotécnico. Associação Brasileira de Mecânica dos Solos e Engenharia Geotécnica, 759 p. Cap. 1, p 85-86.

36. RODRIGUES, R. A. \& VILAR, O. M. (2013) Colapso de solo desencadeado pela elevação do nível d'água. Revista Nacional de Gerenciamento de Cidades, v. 01, n. 06, 2013, pp. 13-27 
37. SANTOS, E. F. (2006) Estudo comparativo de diferentes sistemas de classificações geotécnicas aplicadas aos solos tropicais. 145 p. Dissertação (Mestrado) - Escola de Engenharia de São Carlos, Universidade de São Paulo, São Carlos.

38. SHULL, C. A. (1916) Measurement of the surface forces in soils. The Botanical Gazette, vol. LXII, n. 1, p 01-31.

39. SILVA, P. A. B. A. (1996) Capacidade de carga de grupos de estacas. Dissertação (Mestrado) - Escola de Engenharia de São Carlos, Universidade de São Paulo, São Carlos, $123 \mathrm{p}$.

40. SiBCS (2006) SISTEMA BRASILEIRO DE CLASSIFICAÇÃO DE SOLOS. Empresa Brasileira de Pesquisa Agropecuária. EMBRAPA Solos.

41. SOUZA, A. (1993) Utilização de fundações rasas no solo colapsível de Ilha Solteira (SP). Dissertação (Mestrado). Escola de Engenharia de São Carlos, Universidade de São Paulo, São Carlos, 126 p.

42. SUAREZ, D. A. A. (2008) Estudo do comportamento mecânico de dois solos lateríticos do estado de São Paulo com adição de emulsão asfáltica. Dissertação (Mestrado). Escola de Engenharia de São Carlos, Universidade de São Paulo, São Carlos, $144 \mathrm{p}$.

43. VARGAS, M. (1977) Introdução à mecânica dos solos. São Paulo: McGraw Hill.

44. VIANNA, A. P. F. (2005) Influência da dimensão e da sucção matricial no comportamento de fundações superficiais assentes em solo arenoso não saturado. 308 p. Tese (Doutorado) - Escola de Engenharia de São Carlos, Universidade de São Paulo.

45. VILAR, O. M. (2006) Ensaios de laboratório em mecânica dos solos: opções atuais e perspectivas para um futuro próximo. XIII Congresso Brasileiro de Mecânica dos Solos e Engenharia Geotécnica, p. 25-45.

46. VILAR, O. M.; CINTRA, J. C. A.; PARAGUASSE, A. B.; MACHADO, S. L.; CARVAlHO, M. F. \& CARNEIRO, B. I. J. (1995) Ensaios de campo e de 
laboratório em solos não saturados. Encontro sobre Solos Não Saturados. Porto Alegre - RS. p. 184 - 201

47. VILAR, O. M.; RODRIGUES, J. E.; NOGUEIRA, J. B. (1981) Solos colapsíveis: um problema para a engenharia de solos tropicais. Simpósio Brasileiro de Solos Tropicais. Rio de Janeiro, p. 209-224.

48. VILLAR, L. F. S.; GUIMARÃES, R. C.; RODRIGUES, J. K. G.; AZEVEDO, R. F.; CARVALHO, J. C. (2015) Solos colapsíveis e expansivos. In: CARVALHO et al. Solos Não Saturados no Contexto Geotécnico. 1 ed. ABMS, São Paulo - SP. Cap. 11, p 257-296. 
ANEXO A - CURVA dE CALIBRAÇÃO DAS CÉLULAS DE CARGA E DO TRANSDUTOR DE DESLOCAMENTO
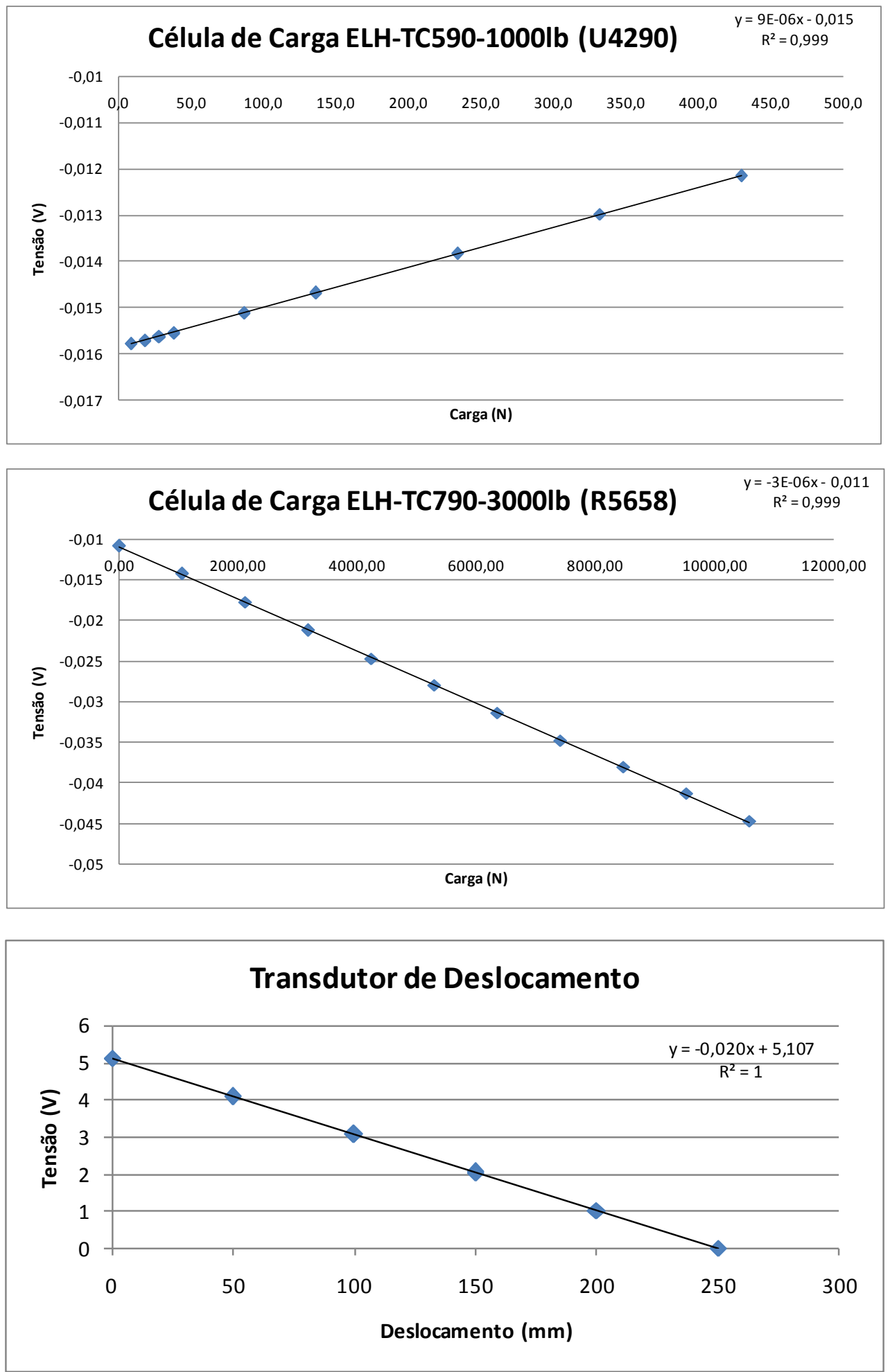
ANEXO B - RESULTADOS DO ENSAIO DE PROVA DE CARGA ESTÁTICA REALIZADA POR FREITAS (2016)

\begin{tabular}{|c|c|}
\hline \multicolumn{2}{|c|}{ Solo Natural com sucção $6 \mathbf{k P a}$} \\
\hline Tensão $(\mathrm{kPa})$ & Deslocamento $(\mathrm{cm})$ \\
\hline 0 & 0,00 \\
6 & 0,05 \\
12 & 0,15 \\
18 & 0,25 \\
24 & 0,33 \\
30 & 0,40 \\
36 & 0,47 \\
42 & 0,51 \\
48 & 0,58 \\
54 & 0,65 \\
60 & 0,82 \\
66 & 0,99 \\
72 & 1,22 \\
78 & 1,46 \\
84 & 1,70 \\
90 & 2,00 \\
102 & 2,31 \\
& 2,70 \\
\hline
\end{tabular}




\begin{tabular}{|c|c|}
\hline \multicolumn{2}{|c|}{ Coluna de Solo Inundada (Compactada 1) } \\
\hline Tensão $(\mathrm{kPa})$ & Deslocamento $(\mathrm{mm})$ \\
\hline 0 & 0,00 \\
10 & 0,75 \\
20 & 1,22 \\
30 & 1,76 \\
40 & 2,05 \\
50 & 2,37 \\
60 & 2,63 \\
70 & 3,03 \\
80 & 3,42 \\
90 & 3,85 \\
100 & 4,14 \\
110 & 4,41 \\
120 & 4,91 \\
130 & 5,23 \\
140 & 5,72 \\
150 & 6,26 \\
160 & 7,05 \\
170 & 7,71 \\
180 & 8,54 \\
190 & 9,34 \\
200 & 10,52 \\
210 & 11,93 \\
220 & 13,19 \\
240 & 15,02 \\
250 & 17,19 \\
& 18,96 \\
\hline
\end{tabular}




\begin{tabular}{|c|c|}
\hline \multicolumn{2}{|c|}{ Coluna de Solo Não Inundada (Compactada 2) } \\
\hline Tensão $(\mathrm{kPa})$ & Deslocamento $(\mathrm{mm})$ \\
\hline 0,00 & 0,00 \\
20,00 & 2,10 \\
40,00 & 4,12 \\
60,00 & 5,35 \\
80,00 & 6,36 \\
100,00 & 7,43 \\
120,00 & 8,61 \\
140,00 & 9,69 \\
160,00 & 10,92 \\
180,00 & 12,37 \\
200,00 & 14,07 \\
220,00 & 16,45 \\
240,00 & 19,63 \\
\hline
\end{tabular}

